UNIVERSIDADE DE SÃO PAULO

FACULDADE DE FILOSOFIA, LETRAS E CIÊNCIAS HUMANAS

DEPARTAMENTO DE LETRAS CLÁSSICAS E VERNÁCULAS

PROGRAMA DE PÓS-GRADUAÇÃO EM LITERATURA BRASILEIRA

RENATA DE CARVALHO NOGUEIRA

A POÉTICA SOCIAL DE PATATIVA DO ASSARÉ

(Versão corrigida) 
RENATA DE CARVALHO NOGUEIRA

\title{
A POÉTICA SOCIAL DE PATATIVA dO ASSARÉ
}

\author{
(Versão corrigida)
}

Dissertação apresentada ao Programa de Pós-Graduação em Literatura Brasileira da Faculdade de Filosofia, Letras e Ciências Humanas da Universidade de São Paulo para obtenção do título de Mestre em Letras.

Área de concentração: Literatura Brasileira.

Orientador: Prof. Dr. Ivan Francisco Marques 
Autorizo a reprodução e divulgação total ou parcial deste trabalho, por qualquer meio convencional ou eletrônico, para fins de estudo e pesquisa, desde que citada a fonte.

Catalogação na Publicação

Serviço de Biblioteca e Documentação

Faculdade de Filosofia, Letras e Ciências Humanas da Universidade de São Paulo

Nogueira, Renata
N778p A poética social de Patativa do Assaré / Renata Nogueira ;
orientador Ivan Marques. - São Paulo, 2017.
164 f.
Dissertação (Mestrado) - Faculdade de Filosofia,
Letras e Ciências Humanas da Universidade de São Paulo.
Departamento de Letras Clássicas e Vernáculas. Área de
concentração: Literatura Brasileira.
1. Patativa do Assaré. 2. Sertão. 3. Poesia social.
4. Poesia popular. 5. Literatura engajada. I. Marques,
Ivan, orient. II. Título.




\section{FOLHA DE APROVAÇÃO}

Renata de Carvalho Nogueira

A poética social de Patativa do Assaré

Dissertação apresentada à Faculdade de Filosofia, Letras e Ciências Humanas da Universidade de São Paulo como requisito à obtenção de título de Mestre em Letras.

Aprovado em:

Banca Examinadora

Prof. Dr. Ivan Francisco Marques (Orientador)

Instituição: FFLCH - USP

Julgamento:

Assinatura:

Prof. Dr. Cláudio Henrique Sales Andrade (Titular)

Instituição: UNINOVE

Julgamento: Assinatura:

Prof. Dr. Paulo Teixeira Iumatti (Titular)

Instituição: IEB - USP

Julgamento:

Assinatura:

Prof. Dr. Fernando Paixão (Suplente)

Instituição: IEB - USP

Julgamento:

Assinatura:

Profa. Dra. Simone Rossinetti Rufinoni (Suplente)

Instituição: FFLCH - USP

Julgamento:

Assinatura:

Profa. Dra. Eliane Robert Moraes (Suplente)

Instituição: FFLCH - USP

Julgamento:

Assinatura: 
Àqueles que, mesmo distantes, sempre semearam a minha educação: minha mãe, Evanda Carvalho, e meu pai, Ademir Nogueira.

Para minha jovem e questionadora irmã:

Fernanda Carvalho. 


\section{AGRADECIMENTOS}

A todos que participaram direta ou indiretamente deste trabalho.

Aos meus pais, que sempre batalharam para garantir a educação das duas filhas na capital, tornando possível a presente pesquisa. A atenção e o orgulho que demonstraram em cada encontro foram essenciais para motivar a caminhada distante de nossa família.

À minha irmã, cujo espírito crítico perante a vida inspirou essas páginas. A quem espero encorajar na continuidade dos estudos e na luta diária nessa cidade alheia.

Ao Prof. Ivan Marques, meu orientador, por abraçar comigo a poesia patativana e me apoiar nessa empreitada de debatê-la no meio acadêmico de nossa universidade. É com muita gratidão que me lembro das inúmeras sugestões aos meus textos e, principalmente, da confiança que depositou em mim.

Aos professores Cláudio Andrade e Paulo Iumatti, membros da banca no Exame de Qualificação, pela leitura atenta e pelos relevantes comentários. Ao Prof. Cláudio Andrade agradeço ainda por ceder seu material de pesquisa e dedicar seu tempo livre para sanar minhas dúvidas em conversas enriquecedoras.

Às amigas da graduação Juliana Schiavoni, por me presentear com um livro de Patativa do Assaré, Catarine Aurora, por se interessar pelo tema e, especialmente, Estefânia Lopes que me auxilia na pós-graduação, demonstrando um entusiástico incentivo à minha pesquisa.

À colega Jhenifer Harmbacher, que, por muito tempo, esteve ao meu lado nas madrugadas de estudos e em todo o processo de seleção para o Mestrado.

Ao meu amigo e companheiro Cassio Martinez, por me acarinhar sempre com pensamentos positivos em momentos de desânimo.

A todos os meus familiares.

Ao Programa de Pós-graduação em Literatura Brasileira.

À Capes pela bolsa de estudos concedida, o que tornou possível minha dedicação exclusiva à pesquisa. 
[...] a literatura corresponde a uma necessidade universal que deve ser satisfeita sob pena de mutilar a personalidade, porque pelo fato de dar forma aos sentimentos e à visão do mundo ela nos organiza, nos liberta do caos e portanto nos humaniza. Negar a fruição da literatura é mutilar a nossa humanidade. Em segundo lugar, a literatura pode ser um instrumento consciente de desmascaramento, pelo fato de focalizar as situações de restrição dos direitos, ou de negação deles, como a miséria, a servidão, a mutilação espiritual. Tanto num nível quanto no outro ela tem muito a ver com a luta pelos direitos humanos. 


\section{RESUMO}

NOGUEIRA, R.C. A poética social de Patativa do Assaré. 2017. 164f. Dissertação (Mestrado) - Faculdade de Filosofia, Letras e Ciências Humanas, Universidade de São Paulo, São Paulo, 2017.

O propósito do presente trabalho é apresentar uma leitura de seis poemas do poeta sertanejo Patativa do Assaré, partindo de um estudo de sua dicção social, tendo em vista a recorrência de elementos de denúncia e de contestação em seus versos. Sendo agricultor no interior do Ceará, o poeta observou e vivenciou a dramática realidade da região nordestina, reconhecendo-se, dessa forma, como porta-voz de seu povo. Com sua visão de um mundo solidário e justo, o poeta documenta o sofrimento e a precariedade das condições de vida dos sertanejos. O grau de consciência que se esconde por trás de sua posição, muitas vezes considerada como rústica ou atrasada, é notável em versos nos quais o poeta aponta a ausência do Estado como principal responsável pelo atraso no sertão, diferentemente da grande mídia que estigmatiza a região em virtude de fatores climáticos, notadamente, a seca. Patativa do Assaré ressalta a perversa relação entre privilégio e privação como condição fomentadora do desequilíbrio e da desigualdade. Logo, a sua poética é marcada por um claro eixo antagônico, no qual a temática social se configura segundo oposições de classes. Com base em tal premissa, propomos uma análise do relevante caráter social da poesia crítica de Patativa do Assaré, ainda pouco debatida nos meios acadêmicos.

Palavras-chave: Patativa do Assaré, Sertão, Poesia social, Poesia popular, Literatura engajada. 


\begin{abstract}
NOGUEIRA, R.C. The Social Poetic of Patativa do Assaré. 2017. Dissertation (Master's degree) São Paulo: Universidade de São Paulo, Faculdade de Filosofia, Letras e Ciências Humanas, 2017.

The purpose of this dissertation is to present an interpretation of six poems from the Brazilian Countryside's poet Patativa do Assaré, starting from a study his social expression, bearing in mind the occuring complaint and contestation elements in his verses. Being a farmer from the countrysde of Ceará, the poet observed and lived the harsh reality of Northeast of Brazil, recognizing himself, this way, as a spokesperson of his own people. Having this view of a solidary and fair world, the poet documents the suffering and substandard life conditions of the people of Northeast. The degree of conscience that is hidden behind his position, many times considered as rustic or obsolete, is clear in verses in which the poet points out the lack of the government as the main responsible for the lack of progress in Ceará's countryside, differently from the mainstream media that stigmatises the region due to weather factors, clearly, the drought. Patativa do Assaré highlights the perverse relation between privilege and deprivation as a factor that triggers the imbalance and inequality. Thus, his poetic is determined by a clear antagonic pillar, in which the social issues are configured according to the social classes opposition. Based on this premise, it is proposed an analysis of the relevent social character of the critical poetry of Patativa do Assaré, still not very discussed in the Academy.
\end{abstract}

Key-words: Patativa do Assaré, Brazilian Northeast countryside, social poetry, popular poetry, Engaged literature. 
INTRODUÇÃO...................................................................................................11

1. PATATIVA DO ASSARÉ: O POETA DO SERTÃO.................................................16

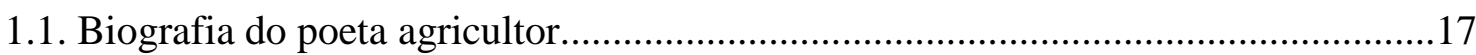

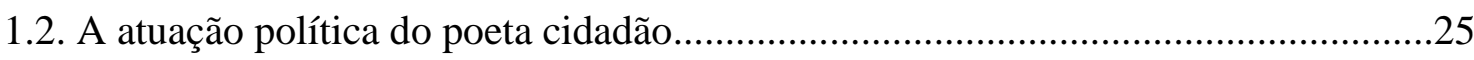

1.3. A poética social de Patativa do Assaré...................................................................30

2. ASPECTOS FORMAIS DA POÉTICA PATATIVANA..................................46

2.1. Influências da poesia popular brasileira e da poesia erudita....................................47

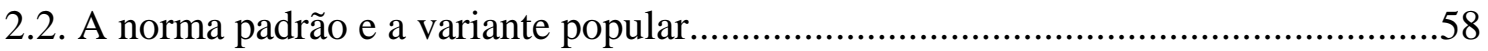

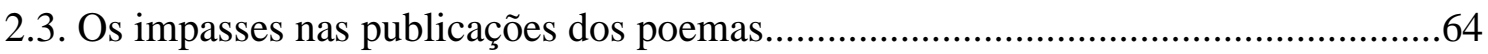

3. ANÁLISE DOS POEMAS.................................................................................69

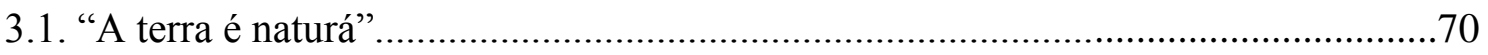

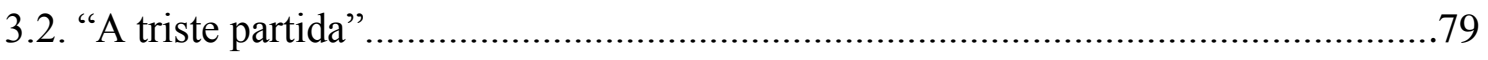

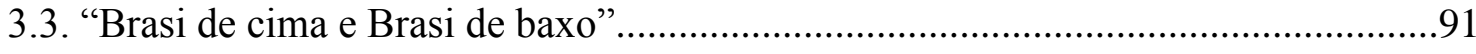

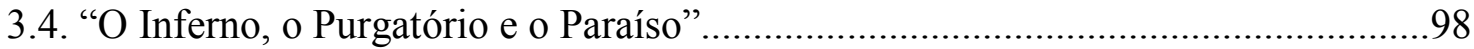

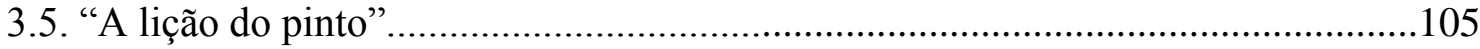

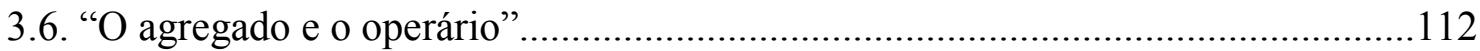

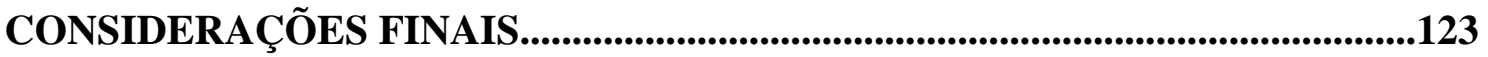

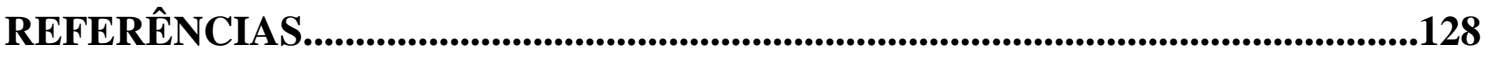

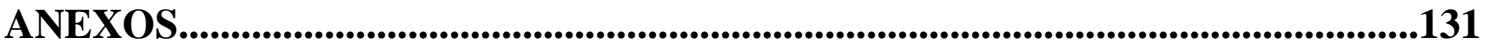




\section{INTRODUÇÃO}


A presente pesquisa busca analisar o canto participante do poeta popular Patativa do Assaré, explorando não apenas a qualidade estética, mas ainda o conteúdo social, ambos marcados pela identidade cultural nordestina. O objetivo do trabalho é analisar a poética desse matuto, que se tomava como porta-voz dos oprimidos; investigar como o poeta sertanejo de admirável consciência social conseguiu tematizar não somente a identidade sertaneja, mas ainda a desigualdade, a miséria e o sofrimento e, por fim, observar como as reflexões patativanas se apresentam nessa obra marcada pela representação das lutas e esperanças do povo.

A expressão cultura popular, sinônimo de cultura do povo, refere-se a uma prática própria de grupos subalternos da sociedade, sendo, então, definida como aquela:

[...] criada pelo povo e apoiada numa concepção do mundo toda específica e na tradição, mas em permanente reelaboração mediante a redução ao seu contexto das contribuições da cultura "erudita", porém, mantendo sua identidade (AYALA, 1987, p. 41).

Entende-se ainda que a cultura popular só pode ser interpretada por oposição à "cultura erudita" e à "cultura de massa", ou seja, constitui-se a partir do confronto entre sistemas culturais: “[...] a cultura popular só se torna compreensível quando relacionada com a dominação e com o conflito entre grupos sociais [...]” (AYALA, 1987, p. 42).

A cultura do povo deve ser analisada dentro de um processo social mais amplo, considerando seus vínculos com as condições de existência e com os interesses de seus produtores e de seu público, tido como um segmento específico da sociedade. Essas manifestações populares constituem-se como formas específicas de representação, reprodução e reelaboração simbólica das relações sociais de dominados e subalternos, isto é, grupos submetidos à hegemonia das classes dominantes. Desse modo,

[...] expressam a consciência que seus produtores e consumidores têm dessa desigualdade e de sua própria situação, subordinada, na estrutura social, veiculando, também, pontos de vista e posições que contestam a ideologia dominante, podendo, portanto, contribuir não para a reprodução, mas para a transformação da estrutura social vigente (AYALA, 1987, p. 58).

Nesse contexto, insere-se o poeta e também camponês Patativa do Assaré, reconhecido como um dos principais representantes da cultura popular nordestina. Antônio Gonçalves da Silva, assim como outros muitos, sobreviveu da roça que plantava na Serra de Santana (pequeno povoado a $18 \mathrm{~km}$ do centro de Assaré, no interior do Ceará), região em que predomina a pequena propriedade. O poeta, portanto, dividiu sua vida entre o trabalho no 
campo, meio de subsistência tradicional para os habitantes daquela localidade, e a composição dos versos que superam as fronteiras do sertão.

Antônio Gonçalves, nome de batismo, tornou-se Patativa do Assaré, nome artístico, por analogia a uma ave canora muito comum na região do Cariri, e o patronímico, por sua vez, transformou-se em sobrenome da persona poética. A força de sua poesia decorre do vínculo existente entre o poeta, o sertão e o humilde caboclo. Seu canto nasce do cotidiano marcado pelo labor e pela fé. O carinho dos sertanejos pelo poeta e os cordéis escritos em sua homenagem são provas de que este se tornou um personagem-chave do panteão nordestino.

A produção patativana está distribuída em cinco livros de poesia: Inspiração nordestina (1956), Novos poemas comentados (1970), Cante lá que eu canto cá (1978), Ispinho e fulô (1988) e Aqui tem coisa (1994), três discos, nos quais recita seus poemas, diversos cordéis e algumas músicas gravadas por cantores, como Luiz Gonzaga e Fagner. A sua poética foi estudada em centros acadêmicos no Brasil, na França e na Inglaterra. Além do reconhecimento como o maior poeta popular do Nordeste, o poeta recebeu inúmeros títulos honoríficos, dentre os quais Doutor Honoris Causa e Cidadão Cearense.

Patativa do Assaré contribuiu para a valorização da cultura popular, subvertendo o juízo recorrente de que as culturas do povo seriam inferiores, exóticas ou pitorescas. Desse modo, os estudiosos comparam o poeta matuto a nomes canônicos da cultura erudita, notadamente, Guimarães Rosa, por buscar a beleza e o valor de sua cultura sertaneja:

Enquanto Rosa é um autor de fina cultura erudita, que olha com amor e respeito para a cultura do sertão, dialogando seriamente com ela, Patativa é o artista formado pela cultura popular que olha e dialoga com a cultura erudita (LOPES, 2003, p. 11).

Os versos patativanos são marcados por uma dualidade de discursos; ora o poeta se vale da norma padrão, ora da chamada "linguagem matuta", isto é, da língua utilizada pelo caboclo nordestino. Essa polaridade revela, simbolicamente, a luta de classes de que Patativa do Assaré sempre buscou conscientizar seu povo. Logo, a poética desse sertanejo é marcada pela reivindicação de mudanças e a busca pela igualdade social: "as idiossincrasias que compõem o artista são muitas, incluem-se nelas o trânsito entre a norma padrão e as variações da linguagem, o registro contundente das ações políticas dos atores sociais, além do tom educativo de sua obra (AGUIAR; CONTE, 2013, p. 96).

Vale enfatizar que poucos poetas sertanejos receberam tanta atenção quanto Patativa do Assaré, cujo traço mais marcante é a aguda consciência de classe, tendo em vista a forte presença de denúncia social em seus versos. Como bem avaliou Paulo César Lopes (2003), 
Patativa do Assaré não se revela um gênio isolado, perdido na pobreza sertaneja, mas um filho desse sertão e dessa cultura, fazendo de sua obra uma síntese de sua gente (p. 12-13). O poeta insiste na observação e na experiência como base do conhecimento autêntico do sertão e afirma que o assunto de sua obra é a verdade, assumindo-se como intérprete da beleza, do sofrimento e dos sonhos do homem do campo. Para o poeta caboclo, literatura não é somente beleza, mas também denúncia, logo, deve se constituir como expressão artística e ainda representar a visão de mundo do intelectual:

Ele [o poeta] deve empregar a sua lira em benefício do povo, em favor do bem comum. Ele deve empregar a sua poesia numa política em favor do bem comum, uma política que requer os direitos humanos e defende o direito de cada um (PATATIVA DO ASSARÉ apud CARIRY, 1982, p. 52).

$\mathrm{Na}$ poesia patativana são evidentes a estrutura social subjacente ao texto e as articulações entre a forma literária e a consciência crítica, já que poeta e poesia colocam-se ao lado do oprimido. Patativa do Assaré assume o seu pertencimento a uma classe social e faz de sua poesia arma simbólica para despertar o engajamento daqueles que não se dão conta das injustiças e das desigualdades não apenas no sertão, como também na cidade:

Meus poemas são assim, porque eu sou muito revoltado contra a injustiça. Sempre fui. Agora, sei respeitar os donos do poder. Eu não vou afrontar ninguém coisa nenhuma. Tanto é que minha poesia é assim dentro desse tema do povo. É assim como um grito de alerta, apresentando o estado da vida aqui... ali na... classe pobre, né? (PATATIVA DO ASSARÉ apud CARVALHO, 2009, p. 61).

Sua indignação diante das injustiças sociais, por sua vez, encontra uma tradução poética para se expressar, distanciando seu projeto literário do mero discurso panfletário. Sobre seu "poema testemunho", Patativa esclarece: "Não é, então, o papel do poeta um papel neutro, de simples observador. O poeta nasceu não só com o dom da poesia, como também com o da verdade e da justiça. O poeta comenta, critica, ensina [...]” (PATATIVA DO ASSARÉ apud CARVALHO, 2002a, p. 46).

A partir da análise de seis poemas patativanos, almeja-se examinar a imagem autoral produzida por esse nome representativo da poesia popular brasileira e observar a construção ficcionalizada que o poeta faz de si mesmo à luz de seu lugar social, de sua identidade histórica e da cena literária em que se mostra inserido. Pretende-se, então, estudar como os recursos e as imagens poéticas são postos a serviço da denúncia social e da reflexão crítica, 
além de explorar o lugar de fala de onde Patativa do Assaré enuncia seu discurso para compreender a construção de sua imagem que oscila entre dois eixos, o pessoal e o público, isto é, entre o camponês e o poeta cidadão, os quais são indissociáveis, já que sua reclusão e reflexão se davam no labor da enxada.

A pesquisa se dividiu em três capítulos. O primeiro capítulo, intitulado "Patativa do Assaré: o poeta do sertão", explora a figura privada e pública do poeta e a temática social recorrente em sua obra, dividindo-se nos subcapítulos: "Biografia do poeta agricultor", "Atuação política do poeta cidadão" e "A poética social de Patativa do Assaré". O segundo capítulo, "Aspectos formais da poética patativana", é composto pelos subcapítulos "Influências da poesia popular brasileira e da poesia erudita", "A norma padrão e a variante popular" e "Os impasses nas publicações dos poemas". Para finalizar, o capítulo "Análises dos poemas" se detém no estudo de seis composições que estão entre as mais conhecidas de sua obra: "A terra é naturá", "A triste partida", "Brasi de cima e Brasi de baxo", "O Inferno, o Purgatório e o Paraíso", “A lição do pinto” e, por fim, "O agregado e o operário". 
CAPÍTULO 1 - PATATIVA DO ASSARÉ: O POETA DO SERTÃO

Meu verso é como a simente Que nasce inriba do chão; Não tenho estudo nem arte, A minha rima faz parte Das obras da criação.

Patativa do Assaré 


\subsection{BIOGRAFIA DO POETA AGRICULTOR}

Todos os críticos e estudiosos de Patativa do Assaré abordam sua biografia, porque a relação entre vida e obra, no seu caso, teve uma coerência e uma unidade pouco comuns na literatura. As experiências e os poemas patativanos se imbricam; a obra não se situa fora do seu contexto biográfico, mas participa de sua vida. O poeta representa a memória popular, logo, sua poesia é ligada ao que vivenciou enquanto homem simples e camponês.

Antônio Gonçalves da Silva, segundo filho de um agricultor pobre da região do Cariri, nasceu no dia 5 de março de 1909 no sítio dos pais, localizado na Serra de Santana, distante três léguas da então Vila do Assaré, sede do município do mesmo nome, ao sul do Ceará. Como filho do casal de agricultores Pedro Gonçalves da Silva e Maria Pereira da Silva, o poeta viveu em meio às pequenas propriedades rurais e sobreviveu através do trabalho da roça realizado em condições primitivas.

Todos os críticos observam a importância da terra natal para Patativa do Assaré, que chegou a declarar que a "Serra de Santana é o meu lugar" (apud FEITOSA, 2003, p. 28). Em entrevista concedida a Gilmar de Carvalho:

\footnotetext{
A Serra de Santana eu posso dizer que é o meu paraíso, viu? Ali eu nasci em mil e novecentos e nove, no dia 5 de março. Sou filho de um agricultor também muito pobre. [...] mas aquela Serra de Santana nunca sai aqui do meu coração. Eu vivo aqui no Assaré, mas o coração ficou lá na Serra de Santana, onde eu trabalhei muito até a idade de sessenta e tantos anos, trabalhando de roça (2002a, p. 17).
}

Acreditava-se, assim, que estaria reservado a ele um destino semelhante ao de seus pais, isto é, a agricultura de subsistência e um baixo nível de escolaridade. Entretanto, a esse futuro modesto se contrapôs o sucesso que tornou Patativa do Assaré um mito na cultura popular. Apesar de viver nas mesmas condições de vida básicas da classe camponesa, manuseando as ferramentas agrícolas na lida da roça para extrair os recursos para a própria subsistência, Patativa se revelou ao mundo como notável poeta popular pelo valor estético e social.

Todos os críticos destacam a pouca instrução escolar a que teve acesso, o que notabiliza suas conquistas no plano intelectual, as quais ele julga uma decorrência do seu dom. Apesar do curto contato com a escola, Patativa se mostrou um autodidata, acumulando leituras de poetas da cultura oficial e mesmo tratados de poética. O sertanejo se valeu de sua simples alfabetização como ferramenta para ler os clássicos, como Camões e, sobretudo, 
Castro Alves, Álvares de Azevedo, Casimiro de Abreu, os livros da primeira fase de Machado de Assis, Guimarães Passos e Olavo Bilac, ou seja, românticos e parnasianos.

Todavia, os estudiosos discordam quanto ao tempo em que Patativa frequentou a escola. Na autobiografia do poeta, presente em seu livro-estreia Inspiração nordestina, lemos: "Com a idade de doze anos, frequentei uma escola muito atrasada, na qual passei quatro meses, porém sem interromper muito o trabalho de agricultor" (2006a, p. 11). Do mesmo modo, Claudio Andrade cita quatro meses de instrução - "A rápida passagem pelos bancos escolares nos quatro meses em que foi aluno não ajuda a entender como Patativa pôde interessar-se por poetas e escritores cultos” (2003, p. 47) -, e também Luiz Tavares Junior, em "Patativa: um cordelista revisitado": "com uma escolaridade mínima de quatro meses, com atrasada professora da roça, saiu lendo Felisberto de Carvalho, famoso manual didático do antigo curso primário" (2012b, s/p). Em contrapartida, Gilmar de Carvalho, por exemplo, registra seis meses de formação escolar:

GC - Quantos anos o senhor fez de escola? Eu sei que o senhor foi um leitor atento e a gente está sempre aprendendo. Mas quantos anos o senhor passou em banco de escola?

PA - De escola, eu passei apenas seis meses, somente. Com seis meses eu aprendi a ler, então, dali por diante meus professores foram os livros, viu? (2002a, p. 21).

Sylvie Debs também afirma seis meses de estudos nessa instituição:

Escolarizado durante seis meses quando tinha 12 anos, ele reconhece que seu mestre, embora extremamente atencioso e generoso, era precariamente letrado e não sabia ensinar a pontuação. É assim que ele aprende a ler sem ponto nem vírgula, como se o ritmo das palavras fosse dado unicamente pela voz (2011, p.15).

Patativa do Assaré perdeu a visão do olho direito aos quatro anos por conta do sarampo. Aos dezesseis, convenceu a mãe a vender uma cabra para comprar a primeira viola e assim começou a cantar nas feiras e fazer versinhos para agradar aos matutos. No entanto, apesar do gosto que sentia por essas apresentações, nunca encarou a arte da viola como uma profissão. Desde menino, o poeta se mostrou rápido no improviso, criativo, porém tímido, o que não o impedia de se exibir em aniversários, casamentos e festas religiosas, nas quais exercitava seu canto:

Eu faço verso desde a idade de 12 anos, mas nunca quis fazer profissão de minha lira. A poesia foi sempre e ainda está sendo a maior distração de minha vida. O meu fraco é fazer verso e recitar para os admiradores, [...] (PATATIVA DO ASSARÉ apud FIGUEIREDO FILHO, 1970, p.13). 
O poeta matuto descobre seu dom para a poesia aos oito anos, quando ainda nem era alfabetizado, através de um deslumbramento diante da linguagem do cordel: "Quando eu tava dentro dos oito anos, eu vi uma mulher lendo um folheto de cordel. Eu fiquei maravilhado. Fiquei encantado mesmo. Ali, naquele momento, me despertou o dom da poesia" (PATATIVA DO ASSARÉ apud CARVALHO, 2002a, p. 24). Trata-se do seu primeiro contato com a poesia:

[...] Comecei a fazer versinhos desde aquele tempo. Sim, a partir do cordel. Porque eu vi o que era mesmo poesia. Aí, dali comecei a fazer versos. Em todos os sentidos. Com diferença dos outros poetas, porque os outros poetas fazem é escrever. E eu não. Eu faço é pensar e deixo aqui na minha memória. Tudo o que eu tenho, fazia métrica de ouvido. Só de ouvido, mas era bonita. Ah! Era! Era bonito mesmo. A base era a rima e a medida. A medida do verso, com a rima, tudo direitinho. Aí, quando eu peguei o livro de versificação de Olavo Bilac e Guimarães Passos, aí eu melhorei muito mais. Eu já tinha de ouvido, porque já nasci com o dom, não é? (PATATIVA DO ASSARÉ apud FEITOSA, 2003, p. 39).

Patativa do Assaré armazenava seus versos na memória, afastando-se, assim, da ideia do poeta de bancada. Sua criação poética estava sujeita ao contato com a natureza, pois sempre se deu durante as tarefas no campo:

[...] Muita gente num sabe como é que eu componho os meus poemas. Não é escrevendo! É... faço a primeira estrofe, deixo retida na memória. A segunda, do mesmo jeito; a terceira e assim por diante. Pode ser um poema de trinta estrofes. Quando eu termino, eu estou com todas elas retidas na memória, aí é que passo para o papel. Sempre fiz verso assim! Meu trabalho manual diariamente nunca interrompeu a minha missão de poeta, de simples poeta do povo, cantando a nossa terra, a nossa vida, a nossa gente, viu? (PATATIVA DO ASSARÉ apud CARVALHO, 2002a, p.13).

O pesquisador Gilmar de Carvalho julga se tratar de uma poesia como canto de trabalho: "Patativa, na serra de Santana, fazendo de seu ofício poético um canto de trabalho. Canto solitário e silencioso, ritmado pelo bater da enxada, [...] Patativa compondo seus poemas, sem lápis e sem papel, guardando tudo na memória” (2002b, p. 64-65).

Aos vinte anos, Patativa do Assaré viajou para fora do estado do Ceará, passando uma temporada de seis meses longe de casa. Em 1929, um primo de sua mãe (Dona Mariô), José Mantoril, um negociante que abandonara Ceará para residir no Amapá, visitou a família e ouviu Antônio improvisar ao som da viola. Deslumbrado com aquela voz, o parente propôs que o rapaz viajasse com ele para Amazônia, onde seria bem acolhido por seus conterrâneos nordestinos. 
Nessa viagem que representa um rito de iniciação, os dois embarcaram em um vapor para Belém do Pará, onde Antônio foi apresentado a um amigo do tio, o Sr. José Carvalho de Brito, estudioso do folclore e correspondente do jornal Correio do Ceará. Este se tornou logo um admirador do poeta, contribuindo futuramente para a divulgação de seus trabalhos. Nessa época, José Carvalho escrevia o livro O Matuto cearense e o caboclo do Pará (1930), no qual acabou incluindo um capítulo sobre o jovem violeiro, por identificar, em Antônio, valores representativos do perfil desse matuto cearense. A alcunha patativa surge graças a um artigo de José Carvalho, publicado no Correio do Ceará, em que este apresenta alguns poemas do jovem poeta-violeiro: "É ave que canta solta / e inda mais canta cativa / seu nome agora é Antônio / crismado por Patativa" (CARVALHO, 2002a, p. 38). Tratava-se de um apelido que ele próprio dera ao jovem assareense; José Carvalho compara o versejar espontâneo e melodioso de Antônio com a beleza do canto da patativa, pequena ave canora do sertão nordestino. A partir de então, Antônio adotou tal pseudônimo e, posteriormente, acrescentou o patronímico de sua terra natal para se distinguir de outros "Patativas" que já haviam surgido.

Com saudades de sua terra e de sua família, Patativa do Assaré voltou para casa. A viagem rendeu-lhe um nome artístico que será recomendado por José Carvalho, em carta, à Dona Henriqueta Galeno, filha do poeta Juvenal Galeno. Pela primeira vez na capital do estado, o sertanejo procurou Dona Henriqueta levando consigo a carta de apresentação do amigo. O poeta passa a fazer apresentações no salão dos Galeno, espaço privilegiado da cantoria e, a partir desse entrosamento e dos poemas publicados em jornais de Fortaleza, sua poesia começa a ganhar fama para além do sertão.

Apesar da notoriedade, Patativa do Assaré apenas abandonou a lida na roça durante a viagem ao Pará e a partir de 1973, quando sua rotina finda devido às sequelas do acidente de automóvel em que fraturou uma perna. O poeta, desse modo, conciliava o trabalho na roça e os convites para as cantorias e recitação de seus poemas. O sertanejo casou-se com Belarmina Cidrão, uma jovem também da serra; casamento que durou 58 anos. Tiveram quatorze filhos, mas apenas nove chegaram à idade adulta.

Em 1951, é fundada a rádio Araripe, do Crato. A radialista Teresinha Siebra, que apresentava um programa de variedades, convidou Patativa do Assaré para uma apresentação. Além das atuações na rádio, o poeta também frequentava a feira do Crato que, realizada todas as segundas, sempre foi referência na vida comercial e nas relações sociais da região, ainda mais forte nos anos 50. O interesse de Patativa pela feira residia tanto no fato de ser agricultor, que ali podia escoar sua pequena produção, quanto no fato de ser artista. 
Vários episódios foram relevantes na trajetória do poeta, entre eles o encontro com José Arraes de Alencar, que o ajudou a publicar o seu primeiro livro. O estudioso de línguas residia no Rio de Janeiro, porém passava as férias no Cariri, revendo a terra natal, e ouviu, na Rádio Araripe, Patativa do Assaré recitar seus poemas. Entusiasmado, o estudioso procurou pelo poeta e o convenceu a publicar seus versos em livro, acreditando que seria uma enorme perda se toda a poética patativana desaparecesse, pois nunca fora transcrita. Apesar da falta de recursos, Patativa aceitou o projeto de publicação; Arraes se encarregou da parte financeira junto ao Editor Borsoi, no Rio de Janeiro, enquanto um amigo seu, Sr. Moacir Mota, filho do folclorista Leonardo Mota, datilografava os poemas que Patativa do Assaré ditava em seus encontros no Crato. Assim, surge, em 1956, Inspiração nordestina, que representou um momento inaugural na vida literária do poeta. Com a venda dos exemplares, feita muitas vezes pessoalmente pelo poeta, pagou-se o investimento.

Dez anos depois, Patativa do Assaré volta ao Rio de Janeiro para uma segunda edição do livro, intitulada Cantos de Patativa, à qual será acrescentada uma nova coletânea de poemas. Entretanto, não publica nesse conjunto "Caboclo roceiro", poema que já havia sido publicado no jornal Folha de Juazeiro, incomodando os censores da ditadura, que chegaram a intimar o poeta a depor.

Aos poucos o sertanejo abandona a prática das cantorias para se concentrar apenas na sua poesia, o que ocorre por volta dos 40 anos. Segundo o poeta, uma das razões para o abandono da atividade de violeiro repentista foi a preferência do público pela recitação de seus poemas, os quais roubavam a cena do próprio desafio. O matuto também preferia os versos mais trabalhados, além do repertório de temas mais rico do que aquele que costumava surgir nas circunstâncias dos desafios, já que os assuntos se referem ao evento ali comemorado ou às sugestões do público. Pode-se inferir, portanto, que Patativa do Assaré mostra uma vocação mais literária.

Em 1965, o poeta compõe “A triste partida”, que logo se torna conhecida pelos violeiros que a cantavam nas festas do sertão. Desse modo, Luiz Gonzaga a ouve na feira do Crato e a grava em disco em 1964. Gonzaga, Raimundo Fagner, que cantou o célebre "Vaca estrela e Boi fubá" (símbolo da aflição do sertanejo diante das amarguras do destino e da exploração), entre outros, contribuíram para a notoriedade nacional de Patativa do Assaré nos $\operatorname{anos} 70$.

Em 1970, é lançada uma coletânea organizada pelo professor J. de Figueiredo Filho, Patativa do Assaré - novos poemas comentados. Figueiredo apresenta os poemas juntamente com seu texto-comentário, subordinando sempre as poesias patativanas a sua apreciação. 
Cante lá que eu canto cá, livro publicado em 1978, apresenta o famoso poema "Prefeitura sem prefeito", marcado por versos satíricos, em que o poeta critica a ausência do prefeito de Assaré em seu posto de trabalho. Seus versos surgiram da necessidade de Patativa encontrar o prefeito, o qual nunca estava em seu posto:

Nessa vida atroz e dura

Tudo pode acontecer

Muito breve há de se ver

Prefeito sem prefeitura;

Vejo que alguém me censura

E não fica satisfeito

Porém, eu ando sem jeito,

Sem esperança e sem fé,

Por ver no meu Assaré

Prefeitura sem prefeito ${ }^{1}$.

Tais versos de improviso em uma das inúmeras visitas infrutíferas, recitados a um guarda municipal, renderam quinze minutos de cadeia ao poeta. Posteriormente, o poeta inconformado aponta a mentira eleitoral para o matuto se precaver em futuros pleitos, declarando em uma entrevista:

[...] o prefeito, como quase todos os candidatos a cargos eletivos, uma vez vitorioso, esquece sempre as promessas anteriores. Se é prefeito esquece tudo e torna-se o dono absoluto da municipalidade, podendo até não frequentá-la com assiduidade (apud CARVALHO 2002a, p. 36).

Em Cante lá que eu canto cá, o poeta finalmente publicou "Caboclo roceiro". Tratase, portanto, de um livro com dois poemas importantes, um que levou Patativa do Assaré à cadeia, e outro que o poeta teve que esconder para não ser preso novamente. Cante lá que eu canto cá tornou-se o seu livro mais conhecido, contando com um esquema de distribuição para todo o Brasil. No poema que dá nome ao livro, o poeta expõe sua filosofia de vida e de mundo, revelando a consciência de ser porta-voz do universo rural.

Em 1973, em Fortaleza, Patativa participa das festas comemorativas do sesquicentenário da cidade, onde sofre um atropelamento. Um dos principais espaços da luta pela redemocratização do país constituía-se na programação cultural do encontro da Sociedade Brasileira para o Progresso da Ciência (SBPC), que, em 1979, rendeu uma homenagem a Patativa do Assaré, também em Fortaleza, valendo-se do título Cante lá que eu

\footnotetext{
${ }^{1}$ (PATATIVA DO ASSARÉ. Melhores poemas: Patativa do Assaré. São Paulo: Global, 2006b, p. 25).
} 
canto cá como lema e epígrafe naqueles tempos de luta pela anistia. Tal circunstância de seu título ser utilizado como emblema representativo do espírito da SBPC contribuiu para levar o nome do poeta ao conhecimento de novos setores da elite intelectual.

Patativa do Assaré, que já havia conquistado o público do sertão nas cantorias e recitais, começa a alcançar e encantar setores da classe média, como professores, estudiosos de literatura e estudantes universitários. A partir de 1978, multiplicam-se as iniciativas e projetos culturais que se interessavam pela obra de poeta, além de eventos que disputavam cada vez mais a sua presença.

Aos 70 anos, Patativa deixa o sítio na serra de Santana e passa a fixar residência em Assaré, já que desde o acidente, o qual lhe rendeu sequelas na perna, não pôde mais plantar roça. Além disso, a cada dia aumentavam os compromissos referentes à divulgação da sua obra, e o poeta também se preocupava com os estudos dos netos: "Rapaz, o analfabetismo é uma tristeza, é um crime..." (PATATIVA DO ASSARÉ apud ANDRADE, 2004, p. 59).

Em Assaré, no ano de 1984, é inaugurado o Centro de Cultura Popular Patativa do Assaré, uma iniciativa de jovens e estudantes. Durante um ano, aconteceram ali exposições, cursos, festas de cultura popular, editou-se ainda um jornal e funcionou uma pequena biblioteca.

Osvaldo Barroso e Rosemberg Cariri, dois estudiosos cearenses, escreveram artigos e estudos sobre a obra de Patativa, alguns posteriormente publicados no livro Cultura Insubmissa. Rosemberg ainda produziu um longa-metragem sobre o poeta, Patativa do Assaré: Ave poesia, e foi o principal articulador da edição de Ispinho e fulô, publicado em 1988.

Tendo em vista o prestígio que o poeta adquiriu, os políticos passaram a homenageálo. O governador Tasso Jereissati, por exemplo, batizou de Rodovia Patativa do Assaré a estrada asfaltada que vai de Assaré até a cidade vizinha, Antonina do Norte:

\footnotetext{
A cidade do poeta assistiu entre atônita e orgulhosa a uma irônica inversão. Se no passado para melhor identificar-se, Patativa agregava a seu pseudônimo o patronímico de sua terra natal, hoje é esta que se socorre do renome do poeta para, pelo menos, não sucumbir ao esquecimento e poder sonhar com o benefício de algumas benfeitorias que lhe acenem com um futuro mais promissor (ANDRADE, 2004, p. 61).
}

Em 1991, Patativa do Assaré e seu sobrinho Geraldo Gonçalves organizam e lançam o livro Balceiro, que reúne poemas de mais de duas dezenas de poetas assareenses. Em 1994, é publicado o último livro do poeta, Aqui tem coisa. No prefácio, Gilmar de Carvalho chama a 
atenção para a dimensão performática na poética de Patativa do Assaré, que, apesar de haver abandonado a poesia da viola e do repente, manteve a sua criação vinculada aos códigos da oralidade, já que sua poesia sempre apresentou uma clara influência da fala popular.

Sabe-se que, mesmo publicado, o sertanejo nunca deixou de ter na voz sua forma de expressão poética. Gilmar destaca que, apesar da poesia de Patativa do Assaré apresentar-se hoje na forma escrita e impressa, ela sempre será uma poesia-performance, isto é, uma poética da voz declamada na presença de ouvintes, a qual focalizava o sertão com suas dificuldades e alegrias.

Em 1995, Patativa do Assaré foi escolhido para integrar a lista das dez personalidades que se destacaram no plano da cultura, recebendo uma premiação pelo Ministério da Cultura, no Teatro Nacional de Brasília. Nesse mesmo ano, no dia 25 de março, o poeta foi homenageado, em Fortaleza, no Teatro José de Alencar, por ocasião do lançamento do CD Patativa do Assaré 85 anos de poesia, contando com a presença do Governador do Estado e do Presidente da República, Fernando Henrique Cardoso, que renderam uma homenagem pública ao poeta popular, conferindo-lhe a medalha José de Alencar.

Em virtude do $90^{\circ}$ aniversário do poeta, foi inaugurado o Memorial Patativa do Assaré, com o intuito de preservar e divulgar a vida e obra deste que é símbolo da cultura popular. No memorial, encontram-se os seus livros, discos e teses sobre o poeta, além de vídeos e fotos de sua trajetória.

Patativa do Assaré faleceu aos 93 anos, no dia 8 de julho de 2002. O poeta sofria há dias de uma pneumonia dupla, uma infecção na vesícula e problemas renais. A causa oficial da morte foi falência múltipla de órgãos. Na ocasião, a Folha de São Paulo publicou uma matéria online, identificando-o como um dos maiores nomes da poesia popular do país.

A obra de Patativa do Assaré é referência nos estudos da cultura popular cearense, ultrapassando fronteiras físicas e intelectuais, haja vista, por exemplo, o interesse do professor Raymond Cantel. O estudioso de cordel se destacou como o primeiro pesquisador francês a se interessar por essa tradição literária, colaborando para a descoberta, o conhecimento, o estudo e a conservação da mesma. Ao percorrer o Brasil a partir de 1959 para recolher textos de repentistas, ganhou o título de "embaixador itinerante", dado pelos repentistas da Bahia. Cantel abordava os versos de Patativa do Assaré em suas aulas sobre cultura popular na Universidade de Sorbonne, na França. Na Inglaterra, por sua vez, a poesia patativana já foi traduzida por Colin Hanfrey, do Centre for Latin American Studies, em Liverpool. Além de ter sido objeto de dissertação de Mestrado, patrocinada pela Universidade Nottingham. 


\subsection{ATUAÇÃO POLÍTICA DO POETA CIDADÃO}

A vida de Patativa do Assaré, apresentada em seus versos, revela um forte caráter religioso, social e político. A contribuição do poeta à cultura brasileira reside na sua capacidade de unir, com singela beleza e arte, a denúncia social ao lirismo. O engajamento do poeta pode ser constatado tanto em sua obra, a qual destaca seu espírito crítico em relação a nossa sociedade, quanto em sua participação efetiva nos comícios e eventos. O sertanejo participou de importantes momentos da história política brasileira, como o movimento de resistência à ditadura militar, a campanha pela Anistia e pelas Diretas-Já. Além disso, o poeta simbolizou para a juventude da década de 1970 uma voz da resistência nas lutas democráticas.

Gilmar de Carvalho foi quem cunhou o apelido de poeta cidadão a Patativa do Assaré: “[...] a poesia de Patativa é uma poesia - cidadã” (2002a, p. 41), entretanto, todos os críticos exploram as atuações políticas do poeta, como quando foi detido por reclamar da prefeitura sem prefeito, nos anos 40, ou quando foi colaborador de jornais alternativos, tendo, então, sua prisão decretada no período autoritário. O poeta ainda, atendendo a uma solicitação de Dom Hélder Câmara, denunciou a morte por repressão do Padre Henrique, no Recife. Ao longo de sua vida e obra, o poeta camponês tomou partido a favor do agregado, do proletariado e dos meninos de rua, além de defender os movimentos libertários, como Canudos e MST.

Patativa do Assaré foi ameaçado de prisão, em 1966, por conta de um poema sobre a questão da terra, "Caboclo Roceiro", publicado no jornal Folha de Juazeiro, por um grupo de estudantes progressistas do Cariri. Em entrevista, o poeta afirmou que a ameaça de prisão deu-se, talvez, por conta da estrofe: "Porém os ingratos, com ódio e com guerra, / tomaram-te a terra que Deus te entregou" (PATATIVA DO ASSARÉ, 2014, p. 100). Vale saber que a expedição de mandato foi relaxada por interferência pessoal de um parente, o qual tinha laços de amizade com os repressores. Esse parente teria rasgado a intimação para o poeta depor no próprio cartório.

Patativa do Assaré teve seus poemas recusados pela Tribuna do Ceará, tornando-se, então, colaborador do jornal Movimento (1977), um dos veículos mais significativos da imprensa alternativa e contestatória ao golpe, durante os anos de ditadura. O poeta também participou da luta pela anistia aos presos e exilados políticos, por meio do metafórico e didático poema "Lição do pinto", quando subiu aos palanques com as principais lideranças oposicionistas brasileiras. Desse modo, como cidadão a favor da anistia, Patativa do Assaré compõe a história do pinto: 


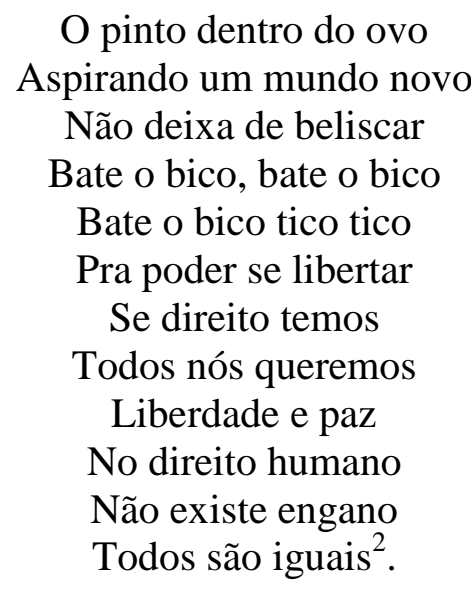

A noção de cidadania de Patativa do Assaré fica clara em sua poesia. O poeta não se omitiu nos principais momentos da história brasileira, notadamente, no período autoritário, em que colaborou com jornais da UNE sob o pseudônimo de Alberto Mororó, quando travou contato com o líder estudantil José Serra, o qual o poeta lamentou que tivesse se afastado dos ideais que defendia. Além disso, o sertanejo se engajou na campanha pelas Diretas-Já com a publicação do poema "Inleição direta 1984":

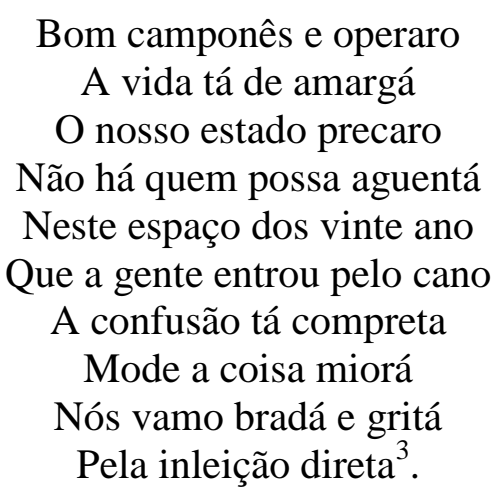

No início dos anos 80, a relação de Patativa do Assaré com os jovens intelectuais se intensificou com o lançamento do jornal Nação Cariri, foco de irradiação cultural no Ceará no final do período autoritário e início do processo de redemocratização, e com o movimento a favor do Centro de Cultura Patativa do Assaré, em sua cidade natal, que, todavia, foi desarticulado por pressões políticas, no final da mesma década. O poeta se tornou uma referência ao grupo de jovens do Crato em decorrência de seu envolvimento no contexto de luta do período autoritário, sendo muito relevante sua presença nas campanhas de mobilização nacional pelo fim do regime militar.

\footnotetext{
2 (PATATIVA DO ASSARÉ. Aqui tem coisa. São Paulo: Hedra, 2012a, p. 127).

3 (PATATIVA DO ASSARÉ. Ispinho e fulô. São Paulo: Hedra, 2005, p. 298).
} 
A consciência crítica social e a participação política de Patativa do Assaré apresentaram atitudes contraditórias. Em virtude de sua posição católica, o poeta chegou a versejar glosas contra o comunismo, em "Quem apoia o comunismo, gosta do Diabo também", encomendadas por um padre conservador de uma cidade do Cariri e utilizadas pelas forças conservadoras nas eleições de 1986. A Igreja católica, sempre atrelada ao poder vigente, manifestava-se contrária ao comunismo, retratando-o como a negação de Deus.

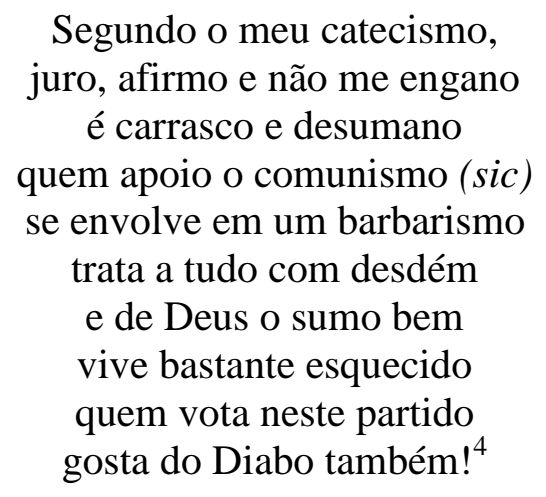

Nesse sentido, Patativa do Assaré não gostava de ser taxado de comunista e se considerava apenas um poeta social. No entanto, em determinada declaração, o poeta matuto associa tal ideologia política e econômica à figura central do cristianismo:

Não tem política do meu jeito, aí eu, também, não sou político [...] Eles me
chamaram de comunista porque eu sempre estive do lado do povo, não é? Eu fiz esta
estrofe: Me taxar de comunista/ É um crime é um pecado/ É atravessar a pista/
Cego, surdo e aleijado/ Se com sentimento nobre/ O que defender o pobre/ Grande
comunista é/ Pertencente à mesma lista/ O primeiro comunista/ Foi Jesus de Nazaré.
[...] O que eu gostei mais de ler foi as pregações de Jesus Cristo, viu? E então, eu
empreguei, também, a minha poesia, defendendo o pobre, defendendo o povo rude
(PATATIVA DO ASSARÉ apud ALENCAR, 2009, p. 85).

Ainda de forma contraditória, o poeta cearense chegou a apoiar o líder comunista Luís Carlos Prestes, em "Vingança de matuto":

Se um dia o Prestes alcançará vitóra

A minha histora lhe contá eu vô,

E peço a ele pra me dá meu sítio

Que o Benidito do meu pai tomou ${ }^{5}$.

\footnotetext{
${ }^{4}$ (PATATIVA DO ASSARÉ. Cordéis. Coleção nordestina. Fortaleza: Edições UFC, 2012b, p. 238).

5 (PATATIVA DO ASSARÉ apud CARVALHO. Patativa do Assaré: um poeta cidadão. São Paulo: Expressão popular, 2011, p. 40).
} 
Em dezembro de 1968, em virtude do AI-5 e do clima de censura, Patativa do Assaré foi obrigado a recuar e alterar os versos que faziam menção a Prestes antes da impressão do livro Novos poemas comentados, para não sofrer novas retaliações. O desfecho do poema que evocava o nome do líder comunista é modificado e passa a clamar por justiça divina:

\section{Minha vingança é que depois da morte \\ Tem ele a sorte de vivê afrito, \\ Lá nas caldêra do purão do Inferno, \\ Tem fogo eterno para o Binidito ${ }^{6}$.}

Em suas inúmeras entrevistas concedidas, Patativa do Assaré afirmava ser eleitor e amigo de Tasso Jereissati, candidato a Governador do Ceará pelo PMDB, nas eleições de 1986, que disputava contra um dos mais tradicionais coronéis do período da ditadura militar, Adauto Bezerra, do PFL (hoje Democratas), o qual já havia sido governador na década de 70. O poeta chegou a subir aos palanques, pedindo votos para o candidato das "mudanças", que, no entanto, para decepção do matuto, envolveu-se no escândalo de desvio de verbas no BEC (Banco do estado do Ceará) em 2002.

Patativa do Assaré, em declarações públicas de voto, sempre revelou seu apoio às tentativas do candidato do PT, Luiz Inácio Lula da Silva, de chegar à Presidência da República nas eleições de 1994 e 1998, por considerá-lo um paradigma de homem político sério. Entretanto, o poeta não viveu o suficiente para ver a chegada de um operário, de origem nordestina, ao principal cargo de poder do país.

A respeito da política, o poeta matuto se julgava apartidário e afirmou:

Não tenho tendência política, sou apenas revoltado contra as injustiças, que venho
notando desde que tomei algum conhecimento das coisas, provenientes talvez da
política falsa, que continua muito fora do programa da verdadeira democracia
(PATATIVA DO ASSARÉ, 2014, p. 16).

Apesar da biografia de Patativa do Assaré atestar sua participação nos palanques eleitorais e colaboração nos jornais alternativos, o poeta negava tais vínculos:

Em meus versos falo sempre em desprezado povo, lamentando o seu sofrimento, contando a verdade sem exagero; se o meu principal tema é este, porém nunca fiz aliança com agitadores, nunca fui colaborador de jornais censurados, nunca fui político, até hoje tenho sido um simples eleitor (PATATIVA DO ASSARÉ apud FIGUEIREDO, 1970, p. 15).

\footnotetext{
${ }^{6}$ (PATATIVA DO ASSARÉ. Melhores poemas: Patativa do Assaré. São Paulo: Global, 2006b, p. 165).
} 
O poeta serviu como emblema tanto de posições conservadoras, em virtude da tradição que representava, quanto esquerdistas que o consideravam um paradigma da resistência por se definir como revoltado contra as injustiças. Em outras palavras, o sertanejo foi transformado em símbolo pela esquerda, que via nele o poeta da resistência por conta de sua sabedoria de vida e visão crítica do mundo, e pela direita, que, por sua vez, exaltava sua autenticidade na valoração do tradicional e da raiz:

\begin{abstract}
Apropriado, ao mesmo tempo, pelos conservadores, que viam nele a manutenção de tradição, e, do outro lado do espectro social, pelos que encontravam em sua fala poética os ecos de uma sociedade que desejavam construir sobre os escombros da velha ordem, Patativa foi capaz de fazer esse trânsito e continuar como o poeta, o sábio e o oráculo. Ele fez questão de se manter em seu lugar privilegiado, de onde interferia na realidade e conservava seus hábitos roceiros, preservando sua privacidade e não se deixando deslumbrar pela sedução da mídia (CARVALHO, 2002, p. 50-51).
\end{abstract}

Em homenagem ao centenário de nascimento do poeta, dois senadores de cores ideológicas diferentes apresentaram Patativa do Assaré da mesma forma. O empresário Tasso Jereissati, ex-governador do Ceará, assim o definiu: "Patativa foi um gênio da cultura popular". Já o comunista Inácio Arruda exaustivamente o chamou de "gênio" e de "poeta popular" (FRANÇA JR., 2009, p. 72). Entretanto, a obra do poeta é muito maior que qualquer rótulo a ele atribuído:

Modesto, ele continuou o mesmo poeta roceiro, o que não o impediu de estar sintonizado com as transformações sociais e de reclamar por uma reforma agrária, por um ideal de justiça e denunciar as mazelas, sem que sua poesia se transformasse em um manifesto ou perdesse sua qualidade estética (CARVALHO, 2009, p. 32-33).

Tendo em vista o envolvimento com a política e a sociedade de seu tempo, a obra do poeta sertanejo se destaca como testemunho estético e político, sintonizando sua idílica terra com os centros de decisão. Ao longo de sua vida, Patativa do Assaré se mostrou como uma voz discordante ao defender os pobres contra os ricos e, assim, incomodar autoridades ao denunciar as desigualdades. Tal atitude demonstra seu comprometimento com a representação da vida do povo, com ênfase nos problemas do tempo presente. O poeta social recitou versos que celebram as grandezas e as misérias do sertão, o que reflete não apenas seu lugar de testemunha desse modo de vida sertanejo, mas ainda sua reivindicação de valores próprios e elaboração de uma identidade. 


\subsection{A POÉtiCA SOCIAL DE PATATIVA dO ASSARÉ}

Figura emblemática da poesia oral, tradicional e popular, que, entretanto, compôs versos na norma padrão, até mesmo oitavas e sonetos, Patativa do Assaré trata em sua obra de uma grande variedade de temas. O poeta revela, aos seus leitores, uma forte relação com a natureza, com o sagrado e com os direitos humanos ao abordar as belezas do seu sertão, os ensinamentos cristãos e a penúria do cotidiano caboclo. Na obra patativana, tudo se mostra articulado, sejam as variantes linguísticas ou os temas religiosos e sociais. Todavia, pode-se afirmar que a maior especificidade de Patativa reside na sua capacidade poética de dar voz a um grupo e a sua vivência social.

Patativa do Assaré se definia como um "matuto sertanejo", cuja existência era traduzida em uma linguagem compreensiva para seus pares. O caboclo se mostrava muito sensível aos temas sociais, como a miséria, a fome, o êxodo rural, as crianças abandonadas, a seca, a reforma agrária etc. O poeta fazia-se porta-voz tanto dos habitantes de sua região, quanto de todos aqueles economicamente excluídos da zona rural e das cidades.

A poética patativana articula ao estético as esferas do subjetivo e do social, revelando em ambas a particularidade sertaneja por ele vivenciada. Cláudio Andrade, por exemplo, divide a poesia patativana em dois conjuntos:

[...] há uma lírica por meio da qual o poeta dá voz aos sentimentos nascidos no encontro com a natureza, com o belo e com as questões propriamente filosóficas da condição humana, ao lado de uma poesia social, voltada para a vida do povo, seus revezes e dificuldades na luta pela sobrevivência e por autonomia e dignidade $(2009$, p. 55).

Em entrevista concedida a Gilmar Carvalho, a distinção entre poesia lírica e poesia social é destacada e o próprio poeta observa a quase totalidade de uma obra engajada:

GC - Patativa gosta de poesias sociais, mas também gosta de uma poesia apaixonada.

$\mathrm{PA}$ - É, mas não tenho muita poesia apaixonada, não. É... quase que não tenho. Eu tenho é... só poesia... quase só poesia social (2002, p. 132).

Assim, ao se falar de Patativa do Assaré, é impossível não pensar, de imediato, no conteúdo social de suas obras, uma vez que sua poética é marcada pela representação das agruras do Nordeste. Como poeta sertanejo da cultura popular, destaca-se, sobretudo, pelo trabalho arguto com o homem simples e anônimo, além de apresentar uma afeição pelo “torrão natal e amado", valorização que, todavia, não mascara as problemáticas da região 
nordestina. Sob esse aspecto, o matuto afirma: "Eu sou um caboclo roceiro que, como poeta, canto sempre a vida do povo. O meu problema é cantar a vida do povo, o sofrimento do meu Nordeste, principalmente daqueles que não têm terra [...]” (PATATIVA DO ASSARÉ, 2005, p. 17).

A referencialidade sociocultural tem um enorme peso na obra patativana, exigindo de nós, leitores, que incorporemos o contex to histórico à forma poética durante sua interpretação. Em Patativa do Assaré, os trabalhos do sociólogo e do estudioso de literatura se combinam:

A obra de Patativa do Assaré com seu compromisso social, com sua dimensão ética orientada em função de valores de inspiração comunitária como verdade, justiça e compaixão, está saturada de temporalidade histórica (ANDRADE, 2004, p. 18).

Antonio Candido, em Vários escritos (2004), caracteriza a literatura como um modelo de coerência gerado pela força da palavra organizada, a qual se torna "um fator que nos deixa mais capazes de ordenar a nossa própria mente e sentimentos e em consequência, mais capazes de organizar a visão que temos do mundo" (p. 177). A partir de tal concepção, Candido aborda o poder humanizador da obra literária que nos liberta do caos e nos humaniza:

\footnotetext{
Entendo aqui por humanização [...] como um processo que confirma no homem aqueles traços que reputamos essenciais, como o exercício da reflexão, a aquisição do saber, a boa disposição para com o próximo, o afinamento das emoções, a capacidade de penetrar nos problemas da vida, o senso da beleza, a percepção da complexidade do mundo e dos seres, o cultivo do humor. A literatura desenvolve em nós a quota de humanidade na medida em que nos torna mais compreensivos e abertos para a natureza, a sociedade, o semelhante (CANDIDO, 2004, p.180).
}

Perante o exposto, Candido situa a literatura social, a qual parte de uma análise do universo social e procura retificar as suas iniquidades. A literatura empenhada deriva de posições éticas, políticas, religiosas ou simplesmente humanísticas do intelectual diante dos problemas. Dessa forma, a partir de suas convicções e pontos de vista acerca da realidade, o autor exprime-as esteticamente com uma tonalidade crítica compondo suas produções literárias. Nesse contexto, desenvolve-se a perspectiva sociológica, a qual analisa as relações entre literatura e sociedade, ou seja, trata-se de uma linha de pesquisa que valoriza o social sem negligenciar a textualidade, pois acredita que, com o substrato histórico-político, pode-se ler, de forma mais ampla, uma obra. A leitura sociológica explora o posicionamento ideológico do intelectual comprometido com os vários elementos que constituem sua realidade social. 
Sobre as relações entre o artista e o meio, pode-se mencionar outra célebre obra de Antonio Candido, Literatura e sociedade (2011). Nesta, o crítico afirma que o poeta não é uma resultante, nem mesmo um simples foco refletor, pois possui o seu próprio espelho. Em seu estudo dialético, Candido indaga não somente qual seria, afinal, a influência exercida pelo meio social sobre a obra de arte, mas ainda, a influência desta sobre aquele. A primeira pergunta consiste em estudar em que medida a arte é expressão da sociedade, enquanto a segunda questiona em que medida a arte é social, isto é, interessada nos problemas coletivos.

$\mathrm{Na}$ crítica moderna, afirmar que a obra de arte exprime a sociedade constitui uma obviedade, pois todos já sabemos que a produção artística é também um produto social, revelando condições de cada civilização em que ocorre. Todavia, observa-se ainda uma segunda tendência interpretativa, a qual analisa o conteúdo social das obras. Desse modo, segundo Candido, ambas as tendências tiveram a virtude de mostrar que a arte é social nos dois sentidos:

[...] depende da ação de fatores do meio, que se exprimem na obra em graus diversos de sublimação; e produz sobre os indivíduos um efeito prático, modificando a sua conduta e concepção do mundo, ou reforçando neles o sentimento dos valores sociais. Isto decorre da própria natureza da obra e independe do grau de consciência que possam ter a respeito os artistas e os receptores de arte (CANDIDO, 2011, p.30).

A arte constitui-se como plano simbólico de comunicação expressiva, isto é, como expressão de realidades profundamente radicadas no artista. Percebe-se, então, o movimento dialético que engloba a arte e a sociedade em um vasto sistema solidário de influências recíprocas. Nos países da América Latina, notadamente, no caso brasileiro, a literatura sempre foi algo profundamente empenhado na construção e na aquisição de uma consciência nacional, de modo que o ponto de vista histórico-sociológico é indispensável para estudá-la. Mais especificamente, as reflexões sobre a cultura popular, no Brasil e em outros países "periféricos", estiveram sempre associadas às discussões sobre a nacionalidade, isto é, a preocupações e lutas políticas e ideológicas:

No Brasil, a partir dos anos 60, essa vinculação não só se intensifica, como se torna mais explícita, fazendo com que os aspectos político-ideológicos passem ao primeiro plano das discussões sobre cultura popular (AYALA, 1987, p. 43).

Constata-se, em Patativa do Assaré, uma poética como campo de acumulação dos problemas nacionais, ou seja, como objeto de reflexão e também de conhecimento de seu país, pois, ao apontar para as contradições sociais, estabelece-se uma crítica vinculada à realidade. 
O poeta é um claro exemplo de literatura empenhada em favor dos direitos humanos, por trazer, para o primeiro plano, o homem do povo com sua penúria.

No prefácio de Cante lá que eu canto cá (2014), Plácido Cidade Nuvens o define como "poeta social": "A realidade local emerge com toda a sua vitalidade na poesia de Patativa. Não apenas na candura lírica do seu telurismo acendrado, mas numa configuração social bem delineada" (p. 14). Dessa forma, com sua tonalidade social, a poética patativana constitui-se como uma crítica às situações de restrição dos direitos ou de negação deles, como a miséria, a exploração econômica e a marginalização.

A obra patativana passa pela estética e pelo engajamento e para tanto apresenta um viés histórico-social. A sua poesia é de interferência social ao apresentar uma série de versos marcados por elementos de denúncia e de contestação, que estampam suas reflexões políticas e sua visão de um mundo solidário e justo. Seus versos passam pela ideia de cidadania como consciência de ser sujeito de ações, isto é, atores sociais e não meros figurantes:

\begin{abstract}
Apesar de toda a força de uma dicção inaugural do mundo e da ancestralidade de que se reveste, é a fala de um homem político, que diz sobre outros homens, em determinadas condições econômicas e sociais, fala que é enunciada de um lugar específico, apesar de sua universalidade, em que subjaz uma regionalidade que, longe de limitar, reforça esse cosmopolitismo sem fronteiras, a partir de todo um substrato de Humanidade (CARVALHO, 2002, p. 59).
\end{abstract}

Gramsci defende que todos os homens são intelectuais, mas nem todos assumem essa função na sociedade. Além de uma gama de tipos de intelectuais (urbanos, industriais, rurais, acadêmicos, técnicos etc.), o filósofo italiano apresenta uma interpretação original das suas funções; deixa de considerá-los de maneira avulsa, ou seja, como estrato separado dos outros, colocando os intelectuais intimamente ligados às relações sociais, pertencentes a uma classe vinculada a um determinado modo de produção:

Cada grupo social, nascendo no terreno originário de uma função essencial no mundo da produção econômica, cria para si, ao mesmo tempo, de um modo orgânico, uma ou mais camadas de intelectuais que lhe dão homogeneidade e consciência da própria função, não apenas no campo econômico, mas também no social e no político [...] (1982, p. 3).

A partir de então, separam-se os intelectuais em duas categorias: os tradicionais e os orgânicos. Para Gramsci, aqueles eram basicamente os intelectuais ainda presos a uma formação socioeconômica superada, como o clero e os acadêmicos, ou seja, homens eruditos e enciclopédicos que se mantinham isolados em abstratos exercícios cerebrais, sempre alheios à própria história. Com seu saber livresco, os intelectuais tradicionais consideravam-se 
superiores e independentes, acima das classes e das adversidades do mundo. Os intelectuais orgânicos, por sua vez, são formados no interior das classes sociais e estão conectados ao mundo do trabalho, às organizações políticas e culturais de determinado grupo. Segundo o filósofo italiano, esses intelectuais assumem a função de representar uma classe e de conscientizá-la, dessa forma, mantêm-se ligados a uma classe social, atuando como seu portavoz.

De acordo com Gramsci, a organicidade dos intelectuais está relacionada a sua profunda vinculação à cultura, história e política das classes subalternas. Enquanto os intelectuais orgânicos estão entrelaçados às classes populares e, portanto, lutam pela expansão dos direitos; os tradicionais, ligados à elite, caracterizam-se pela centralização do poder:

[...] podemos perceber claramente o abismo que separa a concepção dos intelectuais populares que "sentem" com "paixão" a vida dos "subalternos" e os intelectuais convencionais, funcionais à elite e especializados na administração e no controle da sociedade (SEMERARO, 2006, p. 379).

Os intelectuais orgânicos buscam criar outra filosofia e outra política, capazes de promover a superação do poder como dominação e construir a democracia popular. Além disso, devem apresentar a capacidade de alcançar um projeto socializador que reconheça os subjugados como sujeitos políticos:

O intelectual que emerge dos escritos de Gramsci é "orgânico" (voltado a impulsionar a sociedade inteira, não apenas uma parte), democrático (determinado a superar a relação de poder-dominação) e popular (sintonizado com a cultura e os projetos hegemônicos dos "subalternos") (SEMERARO, 2006, p. 387).

Segundo Gilmar Carvalho, Patativa do Assaré deve ser considerado um intelectual orgânico, "no sentido do que formula seus poemas e de sua interferência no mundo, com a força de seu talento e a legitimação de sua sabedoria" (CARVALHO, 2002, p. 47). O estudioso afirma ainda que:

O Brasil que emergia de uma longa noite de censura à liberdade de expressão, com novos partidos políticos, movimentos sociais organizados e a expectativa de tempos melhores, iria encontrar em Patativa do Assaré, aos setenta anos, reconhecido como um intelectual que o teórico marxista italiano Antonio Gramsci chamaria de “orgânico", não fora o complicador de ser camponês, quando essa classificação seria voltada para a classe operária (2002a, p. 45).

Patativa do Assaré mostra-se como a própria voz da comunidade e elemento de sua coesão através da linguagem regionalista, da qual compartilha. Com base nas lembranças 
pessoais, o poeta compõe seus versos, que atuam como um ponto de vista sobre a memória coletiva e popular:

\begin{abstract}
Sua poesia é visceralmente ligada ao que vivenciou. Está impregnada de natureza, com o compromisso de quem sempre esteve em profunda comunhão com a terra. $\mathrm{O}$ paraíso da serra de Santana, a visão que poderia ser idílica é contaminada pela questão da terra, pelas inclemências das secas, em suma, por tinturas realistas que evitam qualquer pieguice e dão a grandeza do que ele canta (CARVALHO, 2002b, p.20).
\end{abstract}

J. de Figueiredo Filho, em Patativa do Assaré - novos poemas comentados (1970), afirma que o poeta é um homem do trabalho cotidiano na lavoura, que defende o nordestino flagelado pela estiagem:

Reside em pequena propriedade, em plena zona acometida, de vez em quando, pelas secas. Sente todo o drama do sertanejo nordestino. Já assistiu a retiradas de massas humanas, expulsas pelo nosso secular flagelo. [...] Já foi testemunha da morte por fome de uma filha muito amada de íntimo amigo. Todo esse sofrimento cantou ele com profundo sentimento. Sentiu a tragédia da seca em sua própria carne. Seu pecado, que para mim é virtude, é desvendar sempre esse drama do Nordeste de que é protagonista (p. 15).

Com base na vida e obra desse "agricultor-poeta", pode-se refletir sobre a distinção entre trabalho manual e experimentação cultural muito debatida nos meios acadêmicos. Sobre isso, em "O trabalho dos intelectuais, segundo Gramsci", Bosi (2003, p.413) relata a velha crença no dom da inteligência, a qual apartaria os intelectuais do trabalho manual e mecânico. Para Gramsci (1966 apud BOSI, 2003, p. 413), trata-se de um claro ranço ideológico da divisão do trabalho. Todavia, segundo ele, o intelectual se constitui como uma pessoa que preenche um conjunto particular de funções na sociedade:

Em qualquer trabalho físico, até no mais mecânico e degradado, existe um mínimo de qualificação técnica, um mínimo de atividade intelectual criadora. Todos os homens são intelectuais, pode-se dizer, mas nem todos os homens têm na sociedade a função de intelectuais. Não se pode separar o homo faber do homo sapiens. Todo homem, fora da sua profissão, exerce alguma atividade intelectual, é um "filósofo", um artista, um homem de gosto, participa de sua concepção de mundo, tem uma linha de conduta moral: contribui para suster ou para modificar uma concepção de mundo, isto é, para suscitar novos modos de pensar (GRAMSCI, 1966 apud BOSI, 2003, p.413).

Patativa do Assaré superou a velha dicotomia entre trabalho manual e trabalho intelectual. Pode-se dizer que trabalho braçal e trabalho mental se confundem no sertanejo, já que o poeta sempre compôs seus versos enquanto lavrava a terra. A poesia, para ele, baseia-se 
em conhecimentos adquiridos pela observação e pela experiência de vida. Não se trata, portanto, de poeta neutro e simples observador, mas de porta-voz de um conhecimento de vida pautado no cotidiano. Nesse contexto, Ria Lemaire observa que:

[...] o método da observação da realidade pela testemunha ocular é a base de tudo [...] vem se juntar a ela uma condição sine qua non: o conhecimento que vem da observação só pode ser adquirido através da experiência de quem vive mesmo no sertão, de quem conhece de dentro a sua realidade (2009, p. 13).

Inúmeros estudiosos exploram a concepção de Patativa do Assaré acerca da poesia e da missão do poeta. O sertanejo se reconhece como porta-voz e testemunha da vida do seu povo: "Minha missão de poeta, de simples poeta do povo, cantando a nossa terra, a nossa vida, a nossa gente, viu?” (PATATIVA DO ASSARÉ apud CARVALHO, 2002a, p. 18). O sujeito lírico, em "Cante lá que eu canto cá”, distingue, assim, o poeta da cidade ao poeta do sertão, pois somente este provou da vida penosa e, portanto, pode cantar o sertão que é seu:

Só canta o sertão dereito, Com tudo quanto ele tem, Quem sempre correu estreito, Sem proteção de ninguém,

Coberto de precisão

Suportando a privação

Com paciença de Jó,

Puxando o cabo da inxada, Na quebrada e na chapada, Moiadinho de suó ${ }^{7}$

Ria Lemaire concebe uma missão dupla à poesia e ao poeta: informar/comentar e ensinar/formar a opinião do povo (LEMAIRE, 2009, p. 14). Segundo a professora holandesa, as duas funções principais dos poetas das civilizações da oralidade são informar as notícias e as novidades, como testemunhas oculares, e ser porta-vozes da memória da comunidade, como testemunhas auriculares dos conhecimentos e das verdades a eles ensinados (2009, p. 22). Do mesmo modo, para Patativa do Assaré, a beleza da poesia reside na verdade. Além dessa verdade do conteúdo, o segundo critério da beleza é o formal, isto é, o ritmo do verso. A verdade exige o ritmo na produção, na transmissão e na sua recepção pelo público para a memorização, tornando todos testemunhas oculares e auriculares.

\footnotetext{
${ }^{7}$ (PATATIVA DO ASSARÉ. Cante lá que eu canto cá. Petrópolis: Vozes, 2014, p. 26-27).
} 
O poeta sertanejo transmite uma verdade social, mais especificamente, uma memória comunitária por ser um grande conhecedor dos problemas de sua classe. Desse modo, Patativa do Assaré sempre se considerou um poeta social cujo dom é transmitir a verdade ligada ao que seu público e sua comunidade nordestina reconhecem e admitem como tal:

Na visão do poeta, o dom da poesia associa-se ao conhecimento da verdade; a missão de ser o porta-voz da verdade é apresentada como uma autêntica vocação [...] Podemos concluir que o poeta "nato" nasceu com vários dons: o da arte, da poesia, o da capacidade de ver a verdade e o da visão da justiça (LEMAIRE, 2009, p. 15).

A condição social foi essencial na obra do poeta, que sempre escreveu sobre seu engajamento como camponês e trabalhador, sobre o homem da zona rural e da cidade ("Canto lá que eu canto cá”), o êxodo rural (“A triste partida”), a reforma agrária (“A terra é naturá”), o drama das crianças abandonadas ("Menino de rua"), a opressão dos pobres pelo poder ("Teia de aranha"), as desigualdades sociais ("Brasi de cima e Brasi de baxo"), as três classes sociais (“O inferno, o purgatório e o paraíso"), as greves (“O boi zebu e as formigas") etc:

Inegável que sua sensibilidade, a indignação diante das injustiças sociais, a fluência para encontrar uma tradução poética, para o que de outro modo seria apenas mais um discurso panfletário, atingem em Patativa uma culminância que fazem dele uma espécie única (CARVALHO, 2002b, p. 16-17).

A identidade sertaneja descrita a partir do caboclo roceiro evoca uma vida extremamente difícil e hostil. A coragem, a paciência e a resistência aparecem como principais atributos dos sertanejos. No entanto, Patativa do Assaré declara que tal condição é resultado do descaso governamental:

Eu incentivei o povo, esclareci para que ele tenha uma compreensão melhor e veja que o seu sofrimento não é permitido por Deus. Ele é uma vítima dos governantes, dos opressores, vamos dizer, né? Nós sabemos disso, então eu, com os meus versos, esclareço a ele e acho que estou fazendo o bem (PATATIVA DO ASSARÉ apud DEBS, 2009, p.114).

Alfredo Bosi, no ensaio intitulado "Poesia resistência" (2000), comenta que a resistência ascende juntamente com a "má positividade" do sistema capitalista: "A poesia há muito que não consegue integrar-se, feliz, nos discursos correntes da sociedade" (p.165). No interior do processo capitalista, o qual se apresenta como um meio hostil e surdo para o poeta, observa-se uma produção contra ideológica, desenvolvendo, assim, a partir do PréRomantismo, uma forma de resistência simbólica aos discursos dominantes. 
Bosi enumera os caminhos de resistência mais trilhados, entre eles a poesia-utopia, que resiste à barbárie e ao caos imaginando uma nova ordem. Tal poesia que almeja uma verdade nova é nomeada por Bosi como utópica por estar fora do tempo como a imaginação criadora:

[...] o poema acende o desejo de uma outra existência, mais livre e mais bela. E aproximando o sujeito do objeto, e o sujeito de si mesmo, o poema exerce a alta função de suprir o intervalo que isola os seres. Outro alvo não tem na mira a ação mais enérgica e mais ousada. A poesia traz, sob as espécies da figura e do som, aquela realidade pela qual, ou contra a qual, vale a pena lutar (BOSI, 2000, p. 227).

Em Thomas Morus (1516), a palavra utopia se afirmou como um sonho e uma construção coletiva, os quais desafiam um presente insatisfatório para se projetar em um ideal de futuro. Utopia constitui-se como a suspensão de um contexto histórico pela edificação de uma sociedade imaginária e ideal, na qual não existe propriedade privada, ao contrário, impera a absoluta comunidade de bens e do solo, sem antagonismos entre cidade e campo. Em resumo, trata-se da utopia igualitária, isto é, de um sonho generoso de renovação social e justiça.

Na poética patativana, o aspecto utópico foi abordado por diversos críticos. Gilmar de Carvalho, em Pássaro liberto (2002), afirma que Patativa do Assaré era um utópico por prevalecer, em sua poesia, a luta pela construção de um mundo melhor (p. 45). Segundo o estudioso, o poeta edifica uma utopia e reforça seu sonho de lugar, a serra de Santana, onde nasceu. Esta se cristalizou não apenas como um paraíso particular, mas como uma concepção de terra partilhada, um ideal solidário de comunidade cristã aliada a um socialismo utópico:

\footnotetext{
Quando ele fala da serra, que é áspera e sertaneja, seca e pedregosa, está falando da terra que poderia ser partilhada. É lá que ele e sua família de pequenos proprietários rurais vive o sonho concreto do chão que se deixa trabalhar [...] Seu sonho de lugar é a utopia de um lugar sem contrastes, de que a serra seria uma espécie de microcosmos. A serra/paraíso, no sentido de possibilidade. Um paraíso poeirento e abafado, feito de suor e improviso, de torneios poéticos e de concretização do sonho de um lugar (CARVALHO, 2002b, p.40).
}

O canto patativano é a resultante de muitos sonhos que se tecem em direção à utopia por uma humanidade solidária, em meio ao individualismo exacerbado. A poesia de Patativa do Assaré rejeita a ambição, o egoísmo e a instrumentalização do homem, portanto, critica a relação sujeito-objeto, exigindo a ruptura da dominação. O poeta dissemina a utopia de uma vida solidária e fraterna: "a perspectiva em que se coloca o matuto com sua utopia de justiça é 
a da forma de vida comunitária, anterior à experiência da segregação implicada no regime da propriedade privada" (ANDRADE, 2004, p. 233).

O poeta canta um manifesto por "terra para trabalhar", contra a propriedade dos bens do doutor. O matuto, em Patativa do Assaré, não aspira a uma mera troca de posições, mas a uma mudança radical da situação, na qual a solidariedade e a justiça social supere o egoísmo e a opressão. Contra a cultura do opressor que gera a segregação e a exclusão, o sertanejo apresenta a utopia de uma sociedade onde não haveria mais opressor nem oprimido. O poeta matuto canta pela existência do camponês, enquanto pequeno proprietário e agricultor de subsistência:

\footnotetext{
A maneira como o matuto afirma sua reivindicação está carregada de um sentimento de honra no trabalho, uma demonstração de orgulho pela força e disposição de que se sente capaz e, por cujo intermédio, tem esperança de melhorar o seu destino e de sua família desde que as razões que acaba de expor, por persuasivas, ponham um freio na ambição desmedida da classe dos proprietários (ANDRADE, 2004, p. 228).
}

Apesar de explorar as figuras da tradição, Patativa do Assaré não evoca tais imagens para se refugiar da realidade opressiva. A utopia do poeta não é escapista, já que este pleiteia a participação, a ruptura com o imobilismo e a instauração de uma nova ordem. O poeta tem plena consciência da dialética do seu "torrão natal"; em sua poética, o Nordeste é apresentado, ao mesmo tempo, como paradisíaco e "flagelado". Os versos de "O retrato do sertão" trazem um sujeito poético que se apresenta como "poeta roceiro", o qual canta as belezas naturais do seu sertão, além das festas como a de São João. Entretanto, o leitor também se depara com a descrição das “cruéis desventuras" sertanejas:

Porém, se ele é um portento

De riso, graça e primor,

Tem também seu sofrimento,

Sua mágoa e sua dor.

Esta gleba hospitaleira,

Onde a fada feiticeira

Depositou seu condão,

É também um grande abismo

Do triste analfabetismo,

Por falta de proteção ${ }^{8}$.

\footnotetext{
${ }^{8}$ (PATATIVA DO ASSARÉ. Cante lá que eu canto cá. Petrópolis: Vozes, 2014, p. 236).
} 
A utopia da abundância, em Patativa, é contida e não hiperbólica, trata-se apenas da perspectiva de que todos tenham acesso a seus direitos básicos. Para tanto, o poeta constrói sua obra como denúncia da estrutura perversa que sustenta um mundo desigual às avessas do ideal de justiça e do conceito de cidadania:

A utopia da abundância se justifica no Nordeste, como se justificava no medievo, pela ameaça de fome. Quem vivenciou um trabalho no campo até os setenta anos, sujeito a todas as adversidades climáticas e à falta de seriedade das políticas públicas neste sentido, sabe, como Patativa, do que fala (CARVALHO, 2002b, p. 41).

O poeta sonha com uma sociedade sem classes, com a superação de um quadro de desigualdades mais contundentes e de privilégios que prevalecem. Logo, a utopia patativana "não renega o sonho, mas trabalha numa interferência do real que necessita de uma transformação, em todos os níveis" (CARVALHO, 2002, p. 45). Em entrevista concedida a Gilmar de Carvalho, Patativa do Assaré, ao ser indagado de onde viera sua preocupação social, se da Igreja ou algum partido político, responde:

É que eu fui um leitor assíduo. Eu gostei muito de ler. E o que eu li com mais prazer sempre era as pregações de Jesus Cristo, viu? Era os direitos humanos, o direito de cada um e, finalmente, foi... Eu, que também de nascimento mesmo, eu comecei logo a ver a verdade, a justiça, viu? (PATATIVA DO ASSARÉ apud CARVALHO, 2000, p. 68).

Patativa do Assaré é, assim, o poeta da luta contra as injustiças sociais, espelhando-se em Castro Alves e em seu famoso poema, "Navio Negreiro", que se torna um modelo de poesia participante: "Sem um maior aprofundamento, pode-se dizer que a poesia social de Patativa é tributária de um socialismo cristão e que seu modelo de denúncia teria sua matriz em Castro Alves. É de onde viria seu repertório" (CARVALHO, 2002, p. 35).

Como cantor das coisas de sua terra, Patativa tornou-se uma espécie de intérprete da beleza, do sofrimento e dos sonhos do homem do campo. O poeta afinou seu canto na perspectiva social do cristianismo primitivo, denunciando a realidade contraditória e perversa em busca da partilha, da igualdade de oportunidades e da correção do social.

Para o eu poético, é inadmissível que a terra, que, segundo acredita, Deus fez para todos, seja propriedade apenas de alguns. Patativa do Assaré cantou sobre a reforma agrária antes mesmo do Movimento dos Trabalhadores Rurais Sem-Terra (MST) surgir. O poeta demonstra apego às coisas da terra, já que, para ele, a terra é obra da Natureza, criação divina, e, portanto, deve contemplar as necessidades de todos que nela e dela vivem: 
Patativa do Assaré talvez seja o poeta que tratou com maior afinco, inspiração e conhecimento de causa, dos problemas referentes à classe camponesa no Brasil. A problemática das condições de existência dessa classe tem merecido a atenção de sua poesia desde a época das Ligas Camponesas, passando pelos tempos tenebrosos da ditadura militar, até os dias correntes, quando o agravamento da questão agrária ganha novamente visibilidade, graças ao Movimento dos Trabalhadores Rurais sem Terra (ANDRADE, 2004, p. 135).

Cláudio Andrade, em Razões da emoção (capítulos de uma poética sertaneja), explora a caracterização sociogeográfica do meio que Patativa do Assaré enuncia. Sabe-se que o poeta vive em um dos estados nordestinos integrantes do polígono das secas. O drama das estiagens e o quadro de miséria e privação estão muito presentes em sua poesia. O camponês pobre é expulso da terra natal não somente pela seca, como também pelo latifúndio. Assim, o poeta não se vale da naturalização reducionista da problemática nordestina, segundo ele, a irregularidade climática não é a causa principal do sofrimento das populações sertanejas, como vendem as mídias.

Andrade, tendo como base o texto de Márcio Moreira Alves, "O despertar do campo", presente no livro $O$ Cristo do povo, aborda as lutas dos trabalhadores rurais contra o latifúndio. Em fins da década de 50, a eclosão de um processo de lutas e reivindicações sociais no campo se organizará no movimento que ficou conhecido como Ligas Camponesas pelos senhores de engenho alarmados com a iniciativa dos trabalhadores (ANDRADE, 2003, p. 140).

Logo, as Ligas Camponesas se espalharam por todo o Nordeste, tendo em vista que as condições do trabalho rural nos engenhos de cana e demais latifúndios geravam conflitos e insatisfações que justificavam a sua existência como movimento social. As reivindicações dos camponeses passaram a integrar a agenda política da esquerda brasileira, cujos principais inimigos eram o latifúndio e o imperialismo norte-americano:

Embora vivendo em seu sítio na Serra de Santana, um tanto distante da região onde o movimento camponês exibia seu maior dinamismo, Patativa do Assaré, por afinidade de classe, e pela circunstância de viver naquela região fronteiriça entre três estados nordestinos e três microrregiões geográficas, serra, sertão e zona da mata, mostrava-se amplamente consciente e atualizado com as questões postas pelo movimento camponês de então (ANDRADE, 2004, p. 141).

Inspiração nordestina, por exemplo, seu livro de estreia, foi publicado em 1956, época em que as reivindicações camponesas acumulavam forças contra o aumento do foro, o trabalho obrigatório sem pagamento, o despejo sem indenização, o uso da violência pelos proprietários de terras etc. Patativa do Assaré sempre esclareceu que o problema no Nordeste não se resume à falta de água, mas sim de terra. Desse modo, ele se reconhece como um 
privilegiado por ser um pequeno proprietário, na Serra de Santana, onde partilha uma terra com os irmãos e os filhos, sem precisar se sujeitar a regimes feudais de relação com os donos para tirar da terra o seu sustento.

Patativa do Assaré julga que um dos problemas mais relevantes no Nordeste é a questão fundiária. O poeta tem consciência de que a dignidade sertaneja residiria nessa condição de propriedade e posse. O eixo de sua discussão se desloca da problemática da água para a questão agrária.

O poeta se revelou um homem integrado à sua terra, em suas tradições e valores, além de unido ao seu irmão sertanejo. A dicção social presente em sua obra representa sua luta por igualdade e democracia:

Patativa, com sua alma pura e seus versos simples, descreve, magistralmente, os contrastes da vida sertaneja. [...] Foi feliz em saber expor com tanta precisão e ritmadamente as belezas e a desgraça do seu povo e de sua gente. (FIGUEIREDO, 1970, p. 44).

A poesia, segundo ele, é um dom natural com o qual a pessoa já nasce, como se fosse escolhido para ser intérprete de seu povo: "Eu nasci com esse dom, com muita facilidade, fazendo versos desde o tempo de menino" (PATATIVA DO ASSARÉ apud ALENCAR, 2009, p. 83). Seu dom se alia a uma espécie de missão social:

\footnotetext{
Tudo que eu tenho, e muitos têm por aí, vem da mesma fonte de sabedoria, e nós não temos esse direito de receber o que recebemos e, agora, criar orgulho, indiferença, não, não temos. Esse direito não é nosso, é de Deus. A poesia é um dom sagrado, ninguém aprende a ser poeta. Sou poeta popular, são simples os versos meus, e sempre onde vou rimar, o principal tema é Deus (PATATIVA DO ASSARÉ apud ALENCAR, 2009, p. 83).
}

$\mathrm{Na}$ visão de mundo patativana, fundem-se valores enraizados na doutrina cristã e a concepção do universo como um livro que contém todas as verdades de que o homem necessita. A associação entre a fé no Deus cristão e a confiança na verdade a que podemos chegar através do Livro da Natureza é o elemento fundante da obra do poeta. Assim, o sertanejo opõe a verdade dos livros, fonte do poder das elites, à do "Livro da Natureza", fonte da sabedoria do poeta popular:

É a observação como base do conhecimento versus o conhecimento artificial dos estudos; é a verdade livresca do poeta "literato" versus a verdade observada pelo poeta "simples", aquele que "leu" na faculdade da natureza, e sempre no plano de fundo: essa visão da igualdade, da anatomia dos dois tipos de conhecimento [...] (LEMAIRE, 2009, p. 27). 
O poeta caboclo reivindica contra o conceito de primitivismo e de inferioridade que o discurso letrado das elites propaga para legitimar a marginalização e a exclusão das tradições do povo. Patativa do Assaré deseja trazer uma ideia da equivalência e autonomia do seu saber, mostrar o valor da civilização que ele representa:

Essa reivindicação da diferença, do reconhecimento e do respeito dela num pé de igualdade desconstrói a dicotomia convencional cujo pressuposto é o da inferioridade do mundo rural, da oralidade, oposta à superioridade do mundo burguês, urbano, do saber livresco, do poder (LEMAIRE, 2009, p. 26).

Há constantemente uma oposição entre o mundo do artifício (das letras, dos doutores) e o mundo sociocultural arcaico próximo do mundo natural. Trata-se, pois, do contraste entre abundância e privação:

\footnotetext{
O lado do doutor tem privilégios, saciedade de bens e direitos; o lado do matuto, ao contrário, tem carência destas mesmas coisas que existem com fartura do outro lado; mas o lado do doutor tem carência de verdade, verdade que será dita pelo matuto. Então, podemos afirmar que o doutor tem saciedade de bens e direito, mas carência de verdade; enquanto o matuto tem carência de bens e direito, mas conhece uma verdade que busca expressar (ANDRADE, 2004, p. 206).
}

Essa relação entre o matuto e o doutor indica que o poema pede para ser lido como uma estrutura subjacente de diálogo, o que o aproxima do regime da oralidade. A oposição de classe social se dá entre protagonista e interlocutor, este que possui privilégios conquistados à custa da exploração do trabalho daquele.

Observa-se nas obras de Patativa do Assaré uma constante estrutura de diálogo, seja entre o matuto e o culto, seja entre o poeta e seus ouvintes. Trata-se muito além de um projeto de reprodução da poesia oral, mas uma marca da tensão social entre tais grupos sociais. Assim, a denúncia da estrutura social injusta e desigual na qual vivemos é evidenciada através do conflito de classes que, por sua vez, está representado nos diálogos.

Cláudio Andrade acredita que o princípio estruturador da poética de Patativa do Assaré refere-se às tensões dualísticas vivenciadas pelo poeta e trabalhadas na linha do jogo poético do desafio: "O desafio enquanto molde dualista que se abre para a expressão do diálogo entre alteridades encena o impasse da vida nacional e acena com a utopia de sua superação" (2004, p. 134).

A partir de oposições, isto é, de um eixo antagônico, Patativa do Assaré desvela o mundo. $\mathrm{O}$ assunto de seus versos se configura segundo contrastes; em seus poemas há 
constantemente dois sujeitos representativos de duas condições sociais antagônicas que o poeta procura descrever por meio de oposição. O dualismo, muitas vezes, manifesta-se no próprio título dos poemas, alguns até títulos dos livros: Cante lá que eu canto cá; "O Brasi de cima e o Brasi de baxo"; Ispinho e fulô; "Nordestinos sim, nordestinados não" etc.

A afirmação da identidade sertaneja passa, frequentemente, pelo confronto entre o sertanejo e o doutor da capital letrado e rico:

\begin{abstract}
Patativa do Assaré propõe uma visão dicotômica do mundo tanto sobre o plano espacial (sertão / cidade; Nordeste / Sul) como sobre o plano temporal (passado / presente). [...] A oposição mundo urbano / mundo rural está construída a partir de diferenças sócio-culturais e do sistema de valores: educação e saber contra analfabetismo e ignorância; dinheiro e bem-estar contra a pobreza e sofrimento; hipocrisia e vaidade contra honestidade e modéstia (DEBS, 2000, p. 32).
\end{abstract}

A poética patativana se mostra realista ao opor dois mundos bastante díspares: "o mundo dos ricos, dos doutores e dos patrões ao mundo dos excluídos, do roceiro, do agricultor analfabeto, a quem as condições de vida e opressão aproximam, inclusive, do seu irmão operário que vive na cidade" (ANDRADE, 2004, p. 149). Dessa forma, muitas vezes, não se trata de uma visão de país cindido por desigualdades regionais, mas a percepção de antagonismos de classe, que geram grupos sociais de excluídos e de privilegiados, tanto no sul como no norte, no campo ou na cidade. As desigualdades regionais não são de todo negadas, mas sim recontextualizadas dentro da luta de classes:

Caracterizando-o pela diferença contrastiva e simétrica que mantém com o matuto, o poeta consegue denunciar a relação de complementariedade e implicação nefasta entre privilégio e privação como condição fomentadora do desequilíbrio e da desigualdade (ANDRADE, 2008, p.198).

Além da oposição constante entre cidade e sertão, os quais abrangem realidades antagônicas, o discurso de Patativa do Assaré sobre o sertão aponta aspectos positivos e negativos desse universo: “[...] força, coragem e valor moral são atributos postos em destaque e que realçam mais ainda por virem ao lado da falta de instrução e da desventura que afligem esses cidadãos" (ANDRADE, 2008, p. 187). O poeta denuncia a precária condição de vida no sertão, mas revela que o sertanejo enfrenta dificuldades e carências sem se entregar ao desânimo.

Apesar da religiosidade sertaneja, que, muitas vezes, assume um tom de passividade e conformismo no que concerne às questões sociais, Patativa do Assaré não crê que seu Deus seja responsável pelo sofrimento do povo. O poeta tem consciência de que o homem é sujeito 
de sua própria história. Assim, por exemplo, em “Nordestinos, sim, nordestinados, não!", rejeita-se a ideia de castigo divino ou destino pré-traçado que condena o nordestino à miséria. No citado poema, o matuto refere-se a Cristo como salvador, entretanto, chama o homem para a luta pela própria libertação no plano político. Do mesmo modo, a fome, para o poeta, não tem "causa divina", isto é, não decorre das intempéries climáticas que condenariam o sertanejo eternamente à miséria, mas sim se revela como reflexo de condições históricas, econômicas e sociais:

Nunca diga nordestino

Que Deus lhe deu um destino

Causador do padecer, Nunca diga que é o pecado

Que lhe deixa fracassado

Sem condições de viver. $[\ldots]$

Não é Deus Quem nos castiga,

Nem é a seca que obriga

Sofrermos dura sentença!

Não somos nordestinados

Nós somos injustiçados

Tratados com indiferença! ${ }^{9}$

Em resumo, a temática central em Patativa do Assaré são os contrastes da vida sertaneja com suas belezas e sofrimentos, manifestando uma luta e um protesto contra a injustiça social. O discurso patativano é de ação social, tendo em vista que o poeta é sensível à dor, à labuta dos que sofrem e pelejam pela sobrevivência. O Deus que permeia toda sua poesia está do lado dos pobres, dos humildes, incentivando o homem à luta. O poeta, assim, não observa apenas a seca, mas também a falta de assistência educacional do homem sertanejo pelo Estado, o que segrega essa gente a um estado de miséria e analfabetismo.

${ }^{9}$ (PATATIVA DO ASSARÉ. Ispinho e fulô. São Paulo: Hedra, 2005, p. 38). 
CAPÍTULO 2 - ASPECTOS FORMAIS DA POÉTICA PATATIVANA

Meu verso rastêro, singelo e sem graça, Não entra na praça, no rico salão, Meu verso só entra no campo e na roça, Nas pobre paioça, da serra ao sertão. Patativa do Assaré 


\subsection{INFLUÊNCIAS DA POESIA POPULAR BRASILEIRA E DA POESIA ERUDITA}

Desde que a formação poética do povo foi encarada como uma manifestação necessária para a definição de sua índole e caráter, isto é, como um documento de sua história e vitalidade, procurou-se marcar as leis e os princípios que proporcionaram o desenvolvimento dessa poesia popular oriunda da tradição oral.

O Brasil oferece um vasto e complexo campo para o estudo da literatura oral e das crenças populares, por conter três distintos ramos de procedências: o caboclo (indígena), o negro (africano) e o branco (português), que:

[...] possuíam cantos, danças, estórias, lembranças guerreiras, mitos, cantigas de embalar, anedotas, poetas e cantores profissionais, uma já longa e espalhada admiração ao redor dos homens que sabiam falar e entoar (CASCUDO, 2006, p.27).

O estudioso atento à evolução da poesia popular observa as superstições, as festas populares, principalmente aquelas pertencentes à Igreja, como Festa de São João, e ainda as cantigas evocadas pelo povo no seu trabalho. Todas essas referências são exploradas por Patativa do Assaré, como se pode verificar nos poemas abaixo:

\section{No meu sertão}

A gente do meu sertão

Tem a vida acotelada.

Nas noite de sexta-feira

Caçadô não faz caçada,

Temendo grande desgraça.

No meu sertão ninguém passa

Entre dois pau de portêra,

Pois é grande sacrifiço,

Se arrisca a pegá feitiço

Da gente catimbózeira ${ }^{10}$.

\section{$O$ retrato do sertão}

É diferente da praça

A vida no meu sertão;

Tem graça, tem muita graça

Uma noite de São João.

No clarão de uma fogueira,

Tudo dança a noite inteira

${ }^{10}$ (PATATIVA DO ASSARÉ. Inspiração nordestina. São Paulo: Hedra, 2006a, p. 125). 
No mais alegre pagode,

E um caboclo bronzeado

Num tamborete sentado

Tocando no pé de bode ${ }^{11}$.

\section{O puxadô de roda}

Seu moço, fique ciente

Que as farinhada dagora,

Tudo é triste e deferente

Das farinhada de otrora

Me lembro, nome por nome,

Das mué, também dos home;

Zé Raimundo era o fornêro,

E alegrava o povo todo

Pegado no pau do rôdo,

Cantando o Macambirêro ${ }^{12}$.

O sujeito lírico no primeiro poema, "No meu sertão", cita várias crenças populares que são denominadas pela "pessoa sabida" como superstição. Para ele, entretanto, trata-se apenas de precauções contra "mandingas" e azar. Já "O retrato do sertão" é mais um entre os vários poemas em que Patativa do Assaré descreve a alegria de uma festa de São João. Por fim, em "O puxadô de roda", o eu-lírico fala ao seu interlocutor sobre a diversão nas "farinhadas de outrora", trazendo os cantos dos trabalhadores. Esses cantos de trabalho do povo eram sempre expressões de alegria na laboriosa luta pela vida "nos grandes eitos lavrando a terra, ou deitando matas ao chão, ou nos engenhos no moer das canas e na preparação do açúcar, sempre o trabalhador vai cantando e improvisando" (ROMERO, 1997, p. 50). Sabe-se que o poeta, como agricultor, também compunha seus versos enquanto lavrava a terra, como declarado em seu poema "Ao leitô", o qual abre seu primeiro livro, Inspiração Nordestina, e serve como apresentação de seus versos:

Em vez de prefume e do luxo da praça

Tem chêro sem graça de amargo suó,

Suó de cabôco que vem do roçado,

Com fome, cansado e queimado de só ${ }^{13}$.

A literatura oral brasileira mostra-se, então, pautada na valorização da memória de um povo, sendo superficial a insistência de alguns antropólogos brasileiros nas representações

\footnotetext{
${ }^{11}$ (PATATIVA DO ASSARÉ. Melhores poemas: Patativa do Assaré. São Paulo: Global, 2006b, p. 28).

12 (PATATIVA DO ASSARÉ. Inspiração nordestina. São Paulo: Hedra, 2006a, p. 23).

${ }^{13}$ (PATATIVA DO ASSARÉ. Inspiração nordestina. São Paulo: Hedra, 2006a, p. 13).
} 
estereotipadas, como a miséria e a seca, imagens congeladas que impedem uma leitura mais rica dessa sociedade e cultura.

Os poetas populares insistem na fidelidade a uma tradição e se apresentam como os mensageiros e como a "voz do povo" (assim também se julgava Patativa do Assaré). Apesar de participarem do cotidiano e da cultura, essencialmente oral, gozam de um status privilegiado no seio da sociedade. O poeta situa-se nas margens e nos limites invisíveis que separam os grupos sociais, os espaços e as culturas; ainda se apresenta como mediador entre o mundo rural e o urbano.

É no contexto da literatura oral brasileira que se insere a chamada literatura de cordel, cujas origens estão relacionadas ao hábito milenar de contar histórias que, aos poucos, passam a ser escritas e, então, difundidas através da imprensa. A littérature de colportage, como se referem os franceses, designa a expressão popular impressa em folheto, o qual apresenta outras inúmeras denominações, como "livrinho de feira", "folhinhas", "folheto de história de matuto", "poesias matutas" etc.

Tais produções literárias, que surgiram em Portugal no século XVI são vendidas nas ruas e penduradas em barbantes:

\footnotetext{
Segundo Ivan Proença (1977), a literatura de cordel portuguesa tem sua origem nos romances tradicionais daquele país. Que eram impressos, rudimentarmente, em folhas soltas ou volantes, e vendidos, presos em um barbante ou cordel, em feiras e romarias. Esses impressos traziam registros de fatos históricos, narrativas tradicionais [...] e também poesia erudita [...]. A circulação das histórias tradicionais, de origem portuguesa e, de modo mais amplo, europeia, e que serviram de base à elaboração de vários folhetos, parece ter sido ampla em Pernambuco desde o século XVIII (GALVÃO, 2006, p. 29).
}

No Brasil, trata-se de uma forma de poesia impressa, produzida e consumida, notadamente em alguns estados da região Nordeste. Apesar da forte presença da oralidade nos textos, o cordel é necessariamente impresso, distinguindo-se de outras formas de poesia oral, como os desafios cantados pelos repentistas. Aquele que escreve os versos dessas produções recebe o nome de cordelista, poeta de bancada ou simplesmente poeta.

Não há um consenso entre os estudiosos quanto às origens da literatura de cordel no Brasil e seu desenvolvimento no Nordeste. Alguns atribuem à literatura de folhetos brasileiros uma filiação direta com o cordel português, enquanto outros a associam com formas de poesia oral já existentes no Nordeste, como as pelejas ou ainda outras formas de expressão oral típicas da sociedade oitocentista brasileira, como os bandos (pregões ou proclamações públicas). Inúmeros cantadores, durante o século XIX e início do XX, transcreviam seus 
versos para vender como folheto. Muitos desafios e outras variantes da poesia popular tinham, no entanto, origem portuguesa. Assim, ocorria uma circularidade entre as diversas formas de cultura (inclusive as indígenas, africanas e de outros povos) em um Brasil marcado pela oralidade.

Apesar de tal polêmica, concorda-se quanto às outras influências associadas ao cordel, como as formas de poesia oral, o hábito de transmitir o patrimônio cultural por meio de histórias, os pregões e outros modos de oralidade comuns em sociedade colonial e imperial, como o Brasil, com baixos índices de letramento. No entanto, ainda mais imprecisas são as razões sobre o desenvolvimento dessa literatura, o qual se deu, quase que exclusivamente, em algumas regiões do Nordeste. Alguns estudiosos arriscam e justificam com o costume de contar histórias nos serões familiares, nas fazendas ou nos engenhos. As histórias e os casos, assim, eram reproduzidos por cantadores ambulantes, que percorriam fazendas e feiras, transmitindo notícias e aproximando pessoas:

\begin{abstract}
Além da conservação precária, devido ao seu papel de má qualidade, dão-se, emprestam-se ou trocam-se textos logo que sejam decorados ou que alguém os haja lido. O interesse principal do aficionado de folhetos não reside na sua conservação com vistas à constituição de uma coleção, nem na identificação do verdadeiro autor, mas no fato de que a história circule, que seja aprendida e lida na presença de um público (CAVIGNAC, 2006, p.72).
\end{abstract}

Os relatos em versos são vendidos, declamados ou cantados nas feiras, nos centros de romarias e nos lugares públicos do Nordeste, tanto no interior quanto no litoral. Eles são comercializados pelos próprios autores ou por revendedores que se deslocam de cidade em cidade. Antigamente os folhetos representavam uma das raras formas de lazer e de informação e eram divulgados principalmente nos engenhos, nas fazendas de criação e no sertão. A leitura era pública e os senhores a ouviam juntamente com os antigos escravos, os moradores, os trabalhadores assalariados e os pequenos proprietários. Como afirma Cavignac "mesmo que se trate de uma literatura escrita, a transmissão do cordel é essencialmente oral: os analfabetos compram regularmente folhetos e pedem a um vizinho ou a um amigo que os leiam” (CAVIGNAC, 2006, p.71).

No que concerne à cultura popular, a busca de sua origem é, muitas vezes, ligada à questão da identidade nacional. Os traços típicos da cultura popular brasileira, assim como da poesia popular, estão presos a um campo pouco inclinado a mudanças. Segundo Cavignac, a literatura popular representa a expressão ingênua da alma de um povo, distinguindo-se da literatura erudita pelo seu público e pela sua forma sempre versificada: 
Quem diz não-erudito diz popular, logo grosseiro e rústico. Daí não falta senão um passo para aproximar essa literatura de sua cultura de origem: a de uma sociedade rural às vezes descrita como arcaica, mas sempre definida como tradicional; uma sociedade na qual o saber se transmite oralmente. O público do cordel é descrito como pertencendo às camadas mais baixas da sociedade. Pequenos camponeses, artesãos ou marginais, o "povo" é com frequência analfabeto (CAVIGNAC, 2006, p.69).

O impasse com o qual nos deparamos refere-se à aproximação e, ao mesmo tempo, distanciamento entre Patativa do Assaré e essa tradição literária. A maioria dos estudos aponta para a vinculação da poética patativana aos códigos da poesia oral, da literatura de cordel e da poesia de cantadores e repentistas. Entretanto, como bem apontou Andrade, "há em Patativa do Assaré uma curiosa convivência entre duas orientações poéticas antagônicas. Uma que impulsiona o poeta a trilhar os caminhos da tradição, outra que o desafia a imprimir uma marca pessoal em sua obra” (2008, p. 9).

Sabe-se que Patativa do Assaré desfrutou de influências oriundas da tradição oral, no entanto, pode-se afirmar que o poeta alargou tais fronteiras. O sertanejo nunca escondeu seu fascínio pela literatura de cordel, a qual foi responsável pelo seu despertar de poeta, isto é, a partir da audição de um folheto, o agricultor se pôs a fazer versos e notar seu dom para a poesia, como declarou em diversas entrevistas.

Em consonância ao cordel, Patativa do Assaré gostava de nomear seus versos como poesia matuta (uma das denominações da literatura cordelista). Ainda, na obra patativana, há uma forte presença do socialismo cristão e uma constante oposição entre o caboclo e o doutor (como já discutido), tais características também são verificadas na tradição dos folhetos. Além disso, a estrutura do diálogo tão forte nos versos de Patativa do Assaré é uma marca do típico embate da peleja, variante do cordel.

Todavia, diferentemente da literatura de cordel, Patativa do Assaré não fora poeta de bancada, tendo em vista que nunca transpôs para o papel seus versos, apenas os guardava na memória, sendo a transcrição feita por terceiros durante a edição de seus livros:

Seja por que dispunha de uma memória verdadeiramente prodigiosa, seja por uma espécie de fusão orgânica entre o fazer poético e o ritmo do trabalho na roça, que foi seu sustento por mais de sete décadas, o fato é que Patativa do Assaré desenvolveu o hábito de compor seus poemas mentalmente, sem auxílio de papel e lápis, em alternância com as braçadas com que manejava a enxada (ANDRADE, 2004, p. 83).

Outras questões relevantes para o distanciamento de Patativa do Assaré do cordel referem-se à rejeição do poeta ao folheto, uma vez que via nessa forma uma fragilidade (como 
já observou Cavignac), mera comercialização e falta de engajamento, pois considerava as temáticas limitadas:

[...] religião e misticismo (com a forte presença de Cristo, dos santos, dos beatos Padre Cícero e Frei Damião - e do diabo), relatos de acontecimentos cotidianos e políticos mais amplos, descrição de fenômenos naturais (como as secas ou as enchentes) e sociais (como o cangaço), decadência dos costumes (muitas vezes associada ao urbano), narração de histórias tradicionais, aventuras de heróis e antiheróis etc. (GALV ̃̃O, 2006, p. 35-36).

Apesar da enorme abrangência dos assuntos dos folhetos, Patativa do Assaré se valeu pouco desses temas, tendo publicado somente treze cordéis, os quais "são produções que fazem uso do formato dos folhetos, mas, ou estão distantes do espírito dos textos que constituem a literatura de cordel, ou fogem-lhe aos padrões de estrofes, esquemas rímicos e número de páginas” (ANDRADE, 2008, p. 10-11). Muito distantes das temáticas centrais da literatura de cordel, os versos de "A triste partida" e "Emigração" foram divulgados em folhetos, além da publicação em livros. Poucos poemas seguem as características poéticas do cordel, como "A lâmpada de Aladim" e "Brosogó, Militão e o Diabo". Patativa do Assaré, portanto, valeu-se pouco do cordel enquanto gênero editorial e ainda menos como gênero poético.

A maior singularidade do poeta reside no seu intenso envolvimento nas estruturas sociais e culturais do sertão. Patativa do Assaré apresenta como projeto a descrição das problemáticas da sociedade do interior do Nordeste. Tavares Junior defende que o poeta inovou a prática cordelística, uma vez que:

[...] assenhorou-se das tecnicidades do verso popular e introjetou em seu espírito a visão de mundo do cordel, as quais transportará para a sua futura poesia, distinguindo-a com o forte estigma do telurismo (2012b, p. 9).

Entretanto, tal afirmação pode ser contestada. A poesia de Patativa do Assaré tanto se distancia do conteúdo do cordel (temas centrais) quanto da forma (esquema métrico).

A métrica, já minuciosamente observada por Cláudio Henrique Andrade em sua tese de doutorado Aspectos e impasses da poesia de Patativa do Assaré, é extremamente rígida, tendo em vista que a utilização de metros e rimas regulares facilita a memorização pelo poeta e pelo público. Os gêneros, tipos e modelos da poesia popular são os mesmos em todo o Brasil. São raros os folhetos escritos em prosa; as formas mais comuns em versos são as 
quadras $\mathrm{ABCB}$, além de sextilhas e décimas. Vale destacar que os cordelistas não cultivaram as formas cultas do soneto nem os versos de doze silabas, como fizera Patativa do Assaré.

As quadras foram os mais antigos cordéis e a métrica se manteve setissilábica, como qualquer cancioneiro espanhol ou português. No entanto, estas representam apenas $13 \%$ da obra patativana.

A sextilha setissilábica, forma mais recorrente na literatura de cordel brasileira, ABCBDB, é, muitas vezes, a forma dos "desafios" e dos romances publicados em todo o Brasil, comentando assuntos diversos, desde o político ao lírico, do geral ao local. Todavia, Andrade constata três diferentes tipos de sextilhas na obra de Patativa do Assaré (2008, p. 86). Dentre as quarenta e seis composições patativanas em sextilhas, apenas nove apresentam-se na modalidade tradicional ( $x \quad a \quad x \quad a \quad x \quad$ ), trinta adotam a sextilha moderna, formada de rimas diferentes que se dispõem de várias maneiras (a mais comum: $a$ a $b \begin{array}{ccc}c & c & b\end{array}$ ), e sete usam a sextilha composta, assim chamada por apresentar versos de duas medidas diferentes (verificar anexo B). Observa-se, então, que a chamada sextilha antiga (cordel) não é a mais utilizada pelo poeta.

As décimas, estrofes majoritárias em Patativa do Assaré, também são estudadas por Andrade, que nota quatro tipos: esquema de rimas tipo A ( $a b a b c c d e e d$, com 109 poemas), esquema de rimas tipo B ( $a b b a$ a $c c d d c$, com 157), esquema de rimas tipo C ( $x$ a $x$ a b b c ddc, com 19) e esquemas de rimas tipo $\mathrm{D}$ ( $x a x a \times a \times a \times a$, com 1 poema). $\mathrm{Na}$ presente pesquisa, entretanto, não foi encontrado o último esquema rímico apontado por Andrade (verificar anexo B).

Apesar desses números, na obra patativana, existem mais estrofes escritas no esquema rímico do tipo A do que no tipo $\mathrm{B}$, isso porque "no caso dos poemas que seguem o primeiro esquema, são poemas longos com muitas estrofes, já os do tipo B, são quase todos relativos à glosa de motes, cerca de 130 deste total consistem em uma só estrofe" (ANDRADE, 2008, p. 114). Desse modo, o poeta mostra-se dissonante à fórmula do Brasil sertanejo:

Na Espanha, usadas entre outros por Cervantes, a fórmula era ABABACCDDC. Em Portugal, era ABBAECCDDE. No Brasil sertanejo é ABBAACCDDC, com influência visível das oitavas clássicas, divulgadas elo Infante dom Pedro de Aragão, ABBACDDC, no tipo formador das "décimas" que sempre tiveram domínio no Brasil letrado, mesmo para a glosa dos “motes" (CASCUDO, 2006, p.368).

Ainda no contexto da tradição oral, temos os desafios populares, que surgiram no fim do século XVIII e eram compostos em quadras, com rimas de forma $\mathrm{ABCB}$. Os outros 
gêneros foram criados depois de 1870 pelos primeiros cantadores repertoriados, naturais do sertão da Paraíba. Embora a poesia popular do Nordeste permaneça em parte fiel à sua origem portuguesa, soube encontrar uma expressão própria, através da elaboração de regras e temáticas novas, adaptadas ao espaço e à sociedade do interior. É na cantoria que se encontram mais invenções e as formas poéticas mais ricas, já que os cantadores improvisam e cuidam mais da forma que do fundo, enquanto nos folhetos a história é essencial. A forma poética dominante tanto no cordel quanto na cantoria permanece a estrofe de seis versos (sextilha) ou de dez (décima). O primeiro verso da estrofe deve em princípio rimar com o último da estrofe precedente cantada pelo outro cantador. Os repentistas improvisam segundo um modelo preciso (sextilha, septilha, décima etc.), levando em conta o tema e também o verso ou o mote que lhe são propostos; as regras se complicam quando a extensão dos versos varia em uma mesma estrofe.

A prática do desafio no Brasil é herança da colonização portuguesa, que se revela como uma manifestação artística de populações interioranas, rústicas e sertanejas de várias regiões do Brasil, com maior popularidade no Nordeste:

Trata-se de uma disputa poética entre dois repentistas onde cada um procura superar o outro, ora pela criação de um verso mais inspirado, fecundo e contundente, [...] ora por atirar ao adversário perguntas difíceis, enigmáticas, quase como advinhas, a que o outro deve responder convincentemente ou dar-se por derrotado (ANDRADE, 2004, p. 68-69).

O desafio, portanto, refere-se a essa manifestação artística da esfera da oralidade, marcada por uma disputa poética em versos, parte improvisada, parte decorada, entre dois cantadores repentistas. Assim, "um jogo que cultua a agilidade mental, a destreza do raciocínio, e glorifica a riqueza de expressão e o talento poético” (ANDRADE, 2003, p. 81). Não se tem uma data que fixe as primeiras manifestações de desafio no Brasil. No entanto, alguns estudiosos consideram que as origens desta disputa poética retrocedem à Grécia arcaica, visto que Homero a empregou na Ilíada e na Odisseia como técnica do canto alternado. Ou seja, trata-se de uma manifestação artística muito primitiva, cujas origens extrapolam a herança ibérica chegando até à civilização grega. A prática do desafio perdura até hoje, tanto na sua forma de molde cultural recuperado por inúmeros artistas na literatura, quanto na música popular urbana (ANDRADE, 2004, p. 70-71).

As cantorias acontecem de modo similar aos desafios realizados na Europa no período da Idade Média, cujas designações variavam: disputa, tenção ou jeux-partis. É relativamente difícil descrever o desenrolar de uma cantoria, pois se trata de uma performance única. Entre 
o rito e o espetáculo, esta varia a cada representação e em função do lugar onde acontece. Dessa forma, tratando-se de uma feira, de um bar, de uma fazenda ou de um concurso, a performance poderá tomar aspectos diferentes. Antes do aparecimento da rádio e dos meios de comunicação atuais, a cantoria era mais presente nos momentos festivos dos sertanejos. Os cantadores eram convidados, com mais frequência, para animar os casamentos e as reuniões familiares nas fazendas; participavam das vaquejadas e de festas religiosas. Mais raros hoje em dia, ocorrem geralmente por ocasião das festas familiares ou da celebração de um santo, principalmente durante a época das colheitas. Logo, observa-se que a cantoria possui um caráter de divertimento; não está ausente, no entanto, um componente de informação: “os cantadores, tidos pelo seu público como homens de inteligência e saber acima do comum, são ouvidos como interesse e curiosidade por uma plateia atenta e silenciosa" (ANDRADE, 2004, p. 73).

Os grandes cantadores raramente escrevem folhetos e os grandes poetas de cordel se arriscam pouco no exercício do repente. Vale ressaltar que, de um ponto de vista formal, há uma distinção fundamental entre poesia escrita e poesia oral. Em virtude de sua função essencialmente narrativa, o cordel adota geralmente uma forma pouco elaborada no nível do emprego dos estilos de composição poética. A cantoria e os outros gêneros de poesia oral, por sua vez, repousam em um conhecimento aprofundado das regras poéticas e são caracterizados por uma improvisação rápida sobre um tema determinado. A distinção entre essas duas formas de expressão poética, fundamentalmente diferentes em seu processo de elaboração, não é sempre claramente delimitada. Uma é oral, cantada e improvisada - a cantoria e os outros gêneros poéticos improvisados -, enquanto que a outra, embora seja às vezes cantada, responde a uma estrutura narrativa formalizada e escrita - o cordel.

Muitos cantadores vivem dessa atividade, assim, durante a apresentação ou ao seu final, passa-se um chapéu, recolhendo, dos presentes, uma contribuição em dinheiro. Os temas das cantorias podem variar, desde assuntos de ocasião, vindos de sugestões dos presentes no evento, saber de "ciência", até temas de romances lendários de origem medieval. Os desafios passaram a ser registrados através da escrita, já que, com o passar do tempo, alguns poetas do repente começaram a fazer a transcrição em folhetos, a fim de ajudar na construção de seu renome, além de ser mais uma alternativa de renda para seu sustento.

A transcrição desses desafios para a escrita quase nunca se limita, unicamente, a reproduzir tal como ocorreram, trazem acréscimos de narrativas ou descrições das circunstâncias e o ambiente em que se desenrolou a disputa. Há também aqueles que escrevem desafios imaginários e, assim, não são repentistas. Estes recebem, na tradição da 
poesia popular no Nordeste, a denominação de poetas de bancada, como fora, por exemplo, Leandro Gomes de Barros.

Patativa do Assaré, por sua vez, foi poeta repentista, sobretudo, na primeira metade de sua vida; posteriormente, abandonou a atividade de violeiro nos desafios e passou apenas a recitar seus poemas, revelando sua predileção por versos mais trabalhados e uma vocação mais literária. Além disso, a cantoria se revela como uma poesia de circunstância, marcado por um mote, o qual nunca é de escolha do poeta, mas sim do público ouvinte. Desse modo, o poeta matuto considerava os desafios pouco autorais.

O agricultor sertanejo julgava-se diferente dos poetas da tradição oral, os quais, segundo ele, viviam imersos em um mundo arcaico e desconheciam o sentimento de propriedade sobre a obra que criam, tendo em vista o princípio da imitação estar acima do princípio da invenção: “[...] é que os cordelistas, eles sempre... eles não criam, não é? Eles gostam de contar aquele passado, isso e aquilo e tal" (PATATIVA DO ASSARÉ apud CARVALHO, 2002a, p. 142). Portanto, a singularidade de Patativa do Assaré reside em sua forte consciência de sentimento comunitário e de autoria, isto é, o poeta apresenta a verdade social presente e se revela autêntico em suas composições:

Patativa sempre fez questão de enfatizar a distância que entendia existir entre o simples versejador e o verdadeiro poeta. Chamava de versejador todo aquele cujo trabalho limita-se à transposição para o verso de obras por outros autores, mera adaptação de enredos já existentes (ANDRADE, 2008, p. 34-35).

Outro diferencial na obra do poeta refere-se à também inspiração na literatura erudita. Patativa do Assaré escreveu sonetos, totalizando 48 poemas, forma inexistente na tradição da poesia oral, entre eles, "Esta terra parece um paraíso":

Eu nasci nesta serra de Santana

Hoje a mesma está muito diferente

Mas a tenho guardada em minha mente

Toda hora e minuto da semana.

Era aqui que eu limpava jitirana Quando a mesma enramava em minha frente

Fui robusto, fui forte e fui valente

Com as graças da Virgem Soberana.

Pedacinho de Terra onde eu nasci 
Um momento de ti não esqueci

E é por isso que em versos eu preciso.

Com as ordens do nosso Criador

Dizer sempre com fé e com amor

Esta Terra parece um Paraíso ${ }^{14}$.

Nos versos acima, nota-se que, apesar de se valer da forma soneto, Patativa do Assaré imprime, nessa tradição literária erudita, as marcas do seu regionalismo sertanejo. O poeta matuto aborda temas típicos de sua obra, como o cristianismo, sua terra natal e a agricultura de subsistência.

Há ainda a estrofe de oito versos (oitavas) de seu poema social "O inferno, o Purgatório e o Paraíso", usada por Camões, na obra épica Os Lusíadas, a qual foi lida por Patativa. Também vale lembrar a décima do tipo A, esquema de rimas observado por Claudio Andrade ( $a b a b c c d e e d$ ), a qual é encontrada em Castro Alves (“O navio negreiro”), poeta muito lido pelo matuto. Logo, entende-se que o poeta mostra-se popular e social não na forma, mas no conteúdo de seus versos, pois a marca da obra patativana é a representação da realidade, valores e crenças do sertanejo.

Seja através da poesia popular, clássica, social, satírica ou performática, Patativa do Assaré mostrou-se porta-voz do homem simples, reconhecendo-se, acima de tudo, como poeta popular e social. Apesar dos inúmeros impasses apresentados nesse trabalho, o sertanejo delimitou com clareza o espaço cultural e a identidade social que compartilha com seu povo nordestino.

${ }^{14}$ (PATATIVA DO ASSARÉ. Melhores poemas: Patativa do Assaré. São Paulo: Global, 2006b, p. 204). 


\subsection{A NORMA PADRÃO E A VARIANTE POPULAR}

Sabe-se que Patativa do Assaré consolidou-se como um dos mais autênticos e importantes representantes da cultura popular nordestina. Quinze anos após sua morte, o poeta ainda é lembrado como referência literária popular. Mas o que destacou o sertanejo entre tantos outros? É impossível encontrar apenas uma resposta. Ao estudar a poética patativana, deparamos-nos com diferentes singularidades, seja no plano do conteúdo ou da expressão.

Interessa-nos estudar, nesse subcapítulo, o uso de duas modalidades linguísticas com diferente prestígio social na poética tão plural de Patativa do Assaré. O próprio poeta afirma que compunha dois tipos de poemas: a poesia "cabocla ou matuta", a qual se vale da variante popular, e a poesia "erudita" pautada na norma padrão. Observou-se, ao longo da pesquisa, que não há regras para o uso de determinada modalidade linguística; assim como existem poemas com temática social escritos em linguagem erudita (“A menina mendiga”), também nos deparamos com versos amorosos compostos à margem da estética oficial ("Meu premêro amô'”).

A linguagem é de extrema relevância como forma de expressão na poesia popular, pois "não é somente no vocabulário, mas também na sintaxe da língua, que o nosso povo exerce o seu inauferível direito de imprimir o cunho de sua individualidade ao instrumento das ideias" (ROMERO, 1997, p. 132). Da mesma forma, Patativa do Assaré valeu-se, muitas vezes, do que ele chamava de "língua cabocla" na composição de seus versos. Diferentemente da norma culta, aquela abraça termos e locuções populares, as quais traduzem os usos e sentimentos desse grupo.

O saber tradicional do povo, frequentemente, é visto com sentido pejorativo, até mesmo como algo risível. Essa depreciação julga ainda as manifestações culturais populares como algo pitoresco, arcaico e inculto, ou seja, alguma coisa superada. Tal corrente, ao acreditar que a cultura popular é rude, rústica e ingênua, opondo-se ao progresso e à civilização, supõe que ela está mais presente no meio rural e em cidades do interior:

O meio rural é considerado o local privilegiado do folclore, desde os primeiros estudos, devido à suposição de que o homem do campo seria mais conservador, tradicional, ingênuo, rude e inculto, atributos tidos por muitos como caracterizadores do folclore. A consequência dessa linha de raciocínio é ver como tudo que se relaciona com a "cultura" e a "civilização" ameaça o folclore (AYALA, 1987, p. 18). 
Essa visão revela um claro preconceito com as manifestações que se distanciam da cultura oficial. Patativa do Assaré, por exemplo, tinha grande consciência da estigmatização que sofria:

Leitô, caro amigo, te juro, não nego

Meu livro te entrego bastante acanhado,

Por isso te aviso, me escute o que digo,

Leitô, caro amigo, não leia enganado.

É simpre, bem simpre, modesto e grôssero,

Não leva o tempero das arte e da escola,

É rude poeta, não sabe o que é lira,

Saluça e suspira no som da viola ${ }^{15}$.

Os versos acima presentes no poema "Ao leitô" (Inspiração nordestina, 2006) exemplificam o conflito da poesia popular com a poesia clássica. O sujeito lírico tem em vista que sua poesia é rejeitada e julgada como menor. Apesar dessa tensão, Patativa do Assaré lutou pela valorização da cultura popular, pois esta desempenha um papel social e traz a verdade do sertão sem ornamentação:

Tu nele não acha tarvez, com agrado

Um trecho engraçado que faça uma escôia, Mas ele te mostra com gosto e vontade,

A luz da verdade gravada nas fôia.

Não vá percurá neste livro singelo

Os canto mais belo das lira vaidosa, Nem brio de estrela, nem moça encantada, Nem ninho de fada, nem chêro de rosa ${ }^{16}$.

A poesia popular de Patativa do Assaré nega a pretensa universalidade da poesia erudita ao afirmar valores e interesses opostos aos vigentes na cultura hegemônica. Seus versos apontam para a existência de diferenças e de desigualdades no interior da sociedade.

Nesse contexto, o sociólogo francês Roger Bastide firma uma perspectiva que busca analisar a cultura popular como parte de um contexto cultural e social mais amplo. Segundo ele, a cultura popular deve ser entendida em termos atuais e não como simples sobrevivência. Bastide critica os estudiosos que analisam os fenômenos culturais isolando-os do complexo social do qual fazem parte. O sociólogo propõe vincular a manutenção e as transformações de

15 (PATATIVA DO ASSARÉ. Inspiração nordestina. São Paulo: Hedra, 2006a, p. 13).

16 (PATATIVA DO ASSARÉ. Inspiração nordestina. São Paulo: Hedra, 2006a, p. 13). 
práticas culturais populares à organização social, às instituições e aos grupos sociais que as realizam.

Hoje se sabe que a cultura popular só é compreensível quando incorporada à vida da comunidade, ou seja, dentro do conjunto estrutural do qual faz parte. Seu estudo exige uma descrição sociológica que a situe no interior dos grupos. Abandona-se a simples descrição da manifestação cultural; o contexto social e o espaço físico deixam de ser tratados como cenário apenas e tornam-se componentes estruturais da análise.

A partir de então, propõe-se um estudo das culturas populares com um olhar sobre as condições de vida, os interesses e os conflitos entre os diferentes grupos sociais. Desse modo, essas manifestações só se tornam compreensíveis quando relacionadas com a dominação e com o conflito entre os grupos, como bem determinou Gramsci, em Literatura e vida nacional:

[...] até hoje, o folclore foi preponderantemente estudado como elemento "pitoresco" (na realidade, até hoje foi apenas coletado material para erudição, e a ciência do folclore consistiu preponderantemente nos estudos a respeito do método de coleta, seleção e classificação deste material, isto é, no estudo das cautelas práticas e dos princípios empíricos necessários para se desenvolver proficuamente um aspecto particular da erudição) [...]. Dever-se-ia estudá-lo, pelo contrário, como "concepção do mundo e da vida", em grande medida implícita, de determinados estratos (determinados no tempo e no espaço) da sociedade, em contraposição (também no mais das vezes implícita, mecânica, objetiva) com as concepções do mundo "oficiais" (ou, em sentido mais amplo, das partes cultas das sociedades historicamente determinadas), que se sucederam no desenvolvimento histórico (1978, p. 183-184).

As reflexões sobre a cultura popular, no Brasil e em outros países "periféricos", estiveram sempre associadas às discussões sobre a nacionalidade, a preocupações e lutas políticas e ideológicas. A cultura do povo passa a ser vista como parte de um processo de exploração econômica e dominação política:

[...] a cultura popular é entendida como produção historicamente determinada, elaborada e consumida pelos grupos subalternos de uma sociedade capitalista, que se caracteriza pela exploração econômica e pela distribuição desigual do trabalho, da riqueza e do poder (AYALA, 1987, p. 51).

Nesse contexto, a cultura popular nordestina tem se afirmado de modo a valorizar a sua produção, enquanto memória e resistência de grupos subalternos da sociedade. Como poeta matuto, Patativa do Assaré apresenta não apenas a realidade concreta de seu povo sertanejo, mas ainda sua linguagem cabocla. Logo, a afirmação linguística do sujeito do discurso patativano sobre a conjuntura sócio-histórica do Nordeste é mais um viés de valorização da cultura popular. 
Tendo em vista que a presente pesquisa buscou analisar o mundo das significações sócio-linguísticas trabalhadas no interior da poética patativana, a primeira questão refere-se a forma que o poeta adotou para ser entendido por todos, sobretudo, pelo povo simples do sertão. Para tanto, observou-se que a obra de Patativa do Assaré transita entre a norma padrão (oficial e erudita) e as variações da linguagem popular (regional e cabocla):

Tenho poesia feita tanto em linguagem certa [erudita], como em linguagem, assim, matuta, como chamamos, linguagem cabocla [...] sou apaixonado pela poesia e conheço a versificação, eu escrevo soneto, escrevo quadrinha, escrevo tudo (PATATIVA DO ASSARÉ apud ALENCAR, 2009, p. 85).

A temática da luta de classes e da igualdade social faz-se presente inclusive no plano formal poético, isto é, o embate entre as variantes linguísticas representa a tensão existente entre o opressor (norma padrão) e o oprimido (variante popular). Notou-se que o poeta busca valorizar e colocar, no mesmo patamar de relevância, as duas linguagens apresentadas.

Patativa do Assaré se vale da variante popular para dar voz ao sertanejo com o seu linguajar próprio. Trata-se de um processo de aproximação e identificação entre o público receptor (o sertanejo), a forma dos poemas (a linguagem) e conteúdo dos mesmos (as agruras vivenciadas pelo sujeito poético caboclo). A poética patativana esclarece, ao povo do sertão, a realidade e a verdade no que concerne à precariedade da existência nordestina. Assim, "o realvivido encontra eco no real-poético" (AGUIAR, CONTE, 2013, p. 174).

Pode-se afirmar que o poeta assume uma posição no interior da luta de classes ao se utilizar da variante popular da língua. O poeta coloca-se ao lado do oprimido, legitimando o direito de fala de homens histórica, social e economicamente explorados:

Sinhô dotô, meu ofiço

É servi ao meu patrão.

Eu não sei fazê comiço, Nem discuço, nem sermão;

Nem sei as letra onde mora, Mas porém, eu quero agora

Dizê, com sua licença, Uma coisa bem singela, Que a gente pra dizê ela Não percisa de sabença. [...]

Iscute o que tô dizendo, Seu dotô, seu coroné:

De fome tão padecendo

Meus fio e minha muié. 
Sem briga, questão nem guerra,

Meça desta grande terra

Umas tarefa pra eu!

Tenha pena do agregado

Não me dêxe deserdado

Daquilo que Deus me deu ${ }^{17}$.

Nesse projeto de dar voz ao matuto, o emprego da linguagem cabocla se dá sem deboche, sendo ainda ferramenta para problematizar as questões sociais, diferentemente da tradição literária que, por muito tempo, valeu-se da forma popular para satirizar o homem pouco instruído. É o caso do cordel, o qual, muitas vezes, mostra-se irônico e busca o riso do leitor por meio da variante popular. Patativa do Assaré demonstra que a enunciação da verdade sobre as coisas do mundo não é monopólio dos letrados e das classes dominantes, pois o sertanejo também é capaz de apontar as injustiças sofridas e reivindicar a igualdade social:

[...] o emprego da linguagem matuta como meio de expressão para dar voz à palavra dos oprimidos em sua luta contra a dominação dos doutores sabichões se constitui numa atitude de contestação fecunda em suas implicações. Em primeiro lugar ao assumir o direito à fala por meio desse tipo de linguagem, tida por "errada" na perspectiva da norma culta, recoloca no terreno da expressão linguística a luta de classes que se desenvolve no plano das realidades históricas com existência extra ou supralinguísticas e a que o discurso poético buscar representar. Esta transposição da luta de classes para o plano da expressão linguística constitui por si mesma uma atitude de resistência e enfrentamento do inimigo de classe na medida em que expressa uma recusa em curvar-se à pretensão de superioridade do dominador com base na instrução, cuja contrafacção encontra-se no estado de carência cultural dos oprimidos. E, por fim, o pressuposto contido nesta atitude de auto-afirmação e enfrentamento que as classes oprimidas tomam em relação a seus adversários é o de que o monopólio da instrução não resulta em monopólio da verdade como procura disseminar a ideologia da classe dominante ao pretender que a verdade e o conhecimento sejam atributos exclusivos de sujeitos com acesso a determinadas competências tipicamente das elites (ANDRADE, 2004, p. 148-149).

Finalmente, no tocante à expressão popular, o poeta assenhora-se da linguagem matuta e dos valores sertanejos para mostrar a realidade dessa região. Em seus versos, Patativa do Assaré dá ao caboclo o direito à voz, o qual passa a ter autonomia. A poética patativana ressoa a voz do povo como canto de luta, tornando emergente a problematização das questões sociais.

${ }^{17}$ (PATATIVA DO ASSARÉ. Cante lá que eu canto cá. Petrópolis: Vozes, 2014, p. 154 e 157). 
O uso da norma padrão, por sua vez, além de revelar que o poeta caboclo também dominava a linguagem de prestígio, legitima o protesto junto às camadas privilegiadas. Podemos pensar aqui no poema "A menina mendiga":

De pés descalços sobre o frio chão, Roto o vestido, em desalinho a trança, De porta em porta a mendigar o pão,

Vai pela rua uma infeliz criança.

O seu estado causa compaixão, Ninguém lhe nota um riso de esperança,

Sempre a estender a sua magra mão,

Canta, pedindo com voz fraca e mansa:

-Ó nobre rico, tende piedade!

Vede como inda no verdor da idade

São dolorosos os martírios meus!

Olhai a pobre que com fome cai:

Não tenho mãe nem conheci meu pai,

Dai-me uma esmola pelo amor de Deus! ${ }^{18}$

Os versos do citado soneto claramente pertencem à chamada "linguagem erudita", como denomina Patativa do Assaré, tendo em vista os hipérbatos, a conjugação dos verbos na fala da criança e a seleção lexical. Vale destacar que todo soneto patativano apresenta-se na norma padrão, como demanda a tradição literária. Apesar de soar estranho esse tom elevado presente na voz da menina, o poeta valeu-se da linguagem de prestígio para interagir com o "nobre rico", interlocutor desse discurso. Aqui não se trata mais do sertanejo e de suas experiências no campo. Os personagens mencionados nesses versos (a menina mendiga e o nobre rico) pertencem ao espaço das grandes cidades, logo, não caberia a linguagem cabocla.

Em resumo, Patativa do Assaré apresenta inúmeras facetas, tendo em vista que publicou não apenas poemas na linguagem nomeada por ele de "matuta", como também versos em "linguagem erudita", inclusive, sonetos. Ao longo da pesquisa foi realizado um levantamento da quantidade de poemas patativanos escritos na norma padrão em oposição ao número de poemas na variante popular. Observou-se que mais da metade da obra poética de Patativa do Assaré (77\%) adota a primeira, enquanto somente $24 \%$ encontram-se na segunda

18 (PATATIVA DO ASSARÉ. Inspiração nordestina. São Paulo: Hedra, 2006a, p. 197). 
(ver anexo C). Vale destacar que, em toda sua produção, há somente um poema que intercala as duas linguagens, “O padre e o matuto”, presente em Inspiração nordestina.

No entanto, vale destacar que, entre os poemas escritos na norma padrão (416 produções), mais de 50\% (216) são motes ou quadras, ou seja, poemas curtos, os quais, muitas vezes, consistem em apenas uma estrofe. O soneto, outra forma fixa de apenas quatro estrofes, sendo sempre escrito na norma padrão, totaliza 11\% (ver anexo D). Já as produções que adotam a variante popular são bem mais extensas em número de versos e estrofes, chegando a 32 estrofes, por exemplo, em "O puxadô de roda", Inspiração nordestina. Desse modo, apesar da majoritária presença de poemas na norma padrão, a "linguagem matuta" é predominante se considerarmos a extensão das produções literárias.

Essas constatações evidenciam que sempre estaremos frente a diversos impasses quando o assunto se refere à obra patativana. O poeta se valeu de inúmeras esferas da tradição oral e também da literatura erudita, produzindo uma poesia singular e multifacetada. Teoricamente, não se pode julgá-lo apenas como poeta popular, pois, como já exposto, o matuto desbravara diferentes modelos de composições poéticas (sonetos, cordéis, quadrinhas etc.) e valera-se de distintas linguagens, entre elas a norma padrão. Entretanto, pode-se afirmar que Patativa do Assaré sempre se reconheceu como poeta popular, tendo escrito sonetos para desconstruir a imagem de poeta menor à margem da estética oficial, em outras palavras, para provar sua capacidade de versejar. Além disso, o poeta valia-se da norma padrão da língua portuguesa para interagir com o interlocutor erudito da capital, enquanto a variante popular servia-lhe para criar empatia com o sertanejo e dar-lhe direito de voz para formular sua filosofia.

\subsection{OS IMPASSES NAS PUBLICAÇÕES DOS POEMAS}

Muito já foi abordado sobre as dificuldades em se estudar a obra patativana. Claudio Andrade, por exemplo, em sua tese de doutorado intitulada Aspectos e impasses da poesia de Patativa do Assaré, explora as singularidades do poeta no âmbito da literatura brasileira. Com foco na forma, Andrade observa como, dialeticamente, o poeta adere e também se distancia da tradição oral, da qual veio: "Patativa é um poeta da tradição, mas não sabemos bem de qual tradição. Do cordel? Da cantoria? Da poesia oral? Da poesia literária? De nenhuma delas exclusivamente e um pouco de cada uma" (ANDRADE, 2008, p. 9). 
Apesar desse afastamento em relação à tradição oral, sabe-se que Patativa do Assaré sempre compôs mentalmente seus versos, os quais guardava na memória. Inspiração nordestina, seu livro-estreia, foi todo datilografado por Moacir Mota, enquanto Patativa recitava nos constantes encontros. Os impasses e diferenciações nas publicações de seus poemas decorrem desse fato.

Essa complexa passagem do oral para o escrito evidencia o fato de que a escrita não era do poeta, resultando em grande variedade de registros ortográficos, muitos contraditórios em relação à expressão oral de Patativa do Assaré. Ao longo da pesquisa, observaram-se alterações não somente nos mesmos versos publicados em diferentes livros, como também nos títulos dos poemas. Tal levantamento dos títulos está apontado na tabela de poemas presente nos anexos do trabalho (anexo A). A maioria dessas diferenças pauta-se na escolha do editor quanto à variante linguística. O título de um poema ora é grafado na "linguagem matuta", ora na norma padrão da língua portuguesa, como "A fogueira de São João" (Inspiração nordestina) e "A foguêra de São João" (Cante lá que eu canto cá e Melhores poemas), "Coisa estranha" (Melhores poemas) e "Cousa estranha" (Novos poemas comentados e Cante lá que eu canto Cá), "O caçador" (Inspiração nordestina) e "O caçadô" (Aqui tem coisa).

Há também casos excepcionais, como “Açaré” (Inspiração nordestina, 1967), "Assarê" (Inspiração nordestina, 2006) e "Assaré de 1957" (Ispinho e fulô). Ainda, "Emigração" (Cordéis), "Emigração e as consequências" (Patativa do Assaré uma voz do Nordeste) e "Emigrante Nordestino no Sul do País" (Cante lá que eu canto cá), cuja diferenciação não se mostra apenas nos títulos, mas também nos versos. Esse poema, nos dois primeiros livros, apresenta quarenta e duas estrofes, enquanto no último apenas trinta e seis. Notou-se que os versos excedentes pertencem a outros poemas. A segunda estrofe presente em Cordéis e Patativa do Assaré: uma voz do Nordeste também é encontrada na segunda estrofe do poema "Vida sertaneja":

Por força da natureza,

Sou poeta nordestino,

Porém só canto a pobreza

Do meu mundo pequenino.

Eu não sei cantá as gulora,

Também não canto as vitora

Dos herói com seus brasão,

Nem o má com suas água...

Só sei cantá minhas mágua

$\mathrm{E}$ as mágua de meus irmão ${ }^{19}$.

${ }^{19}$ (PATATIVA DO ASSARÉ. Cante lá que eu canto cá. Petrópolis: Vozes, 2014, p. 75). 
A décima segunda estrofe também é encontrada em outro poema, no caso, na primeira estrofe de "Minha reza":
A fome é o maior martírio
Que pode haver neste mundo,
Ela provoca delírio
E sofrimento profundo
Tira o prazer e a razão
Quem quiser ver a feição
Da cara da mãe da peste
Na pobreza permaneça,
Seja agregado e padeça
Uma seca no Nordeste ${ }^{20}$.

Além de alterações nos versos: "Ante tanta consequência, / Viajam pelas estradas / Tanjidas pela indigência" (PATATIVA DO ASSARÉ, 2014, p. 326-327) e "Por causa desta inclemência / Viajam pelas estradas / Na mais cruel indigência” (PATATIVA DO ASSARÉ, 2012b, p. 169).

Outro problemático erro de edição refere-se a um dos mais comentados poemas de Patativa do Assaré, "O inferno, o purgatório e o paraíso", presente no livro Cante lá que eu canto cá. A edição mais antiga (1978) traz erroneamente a segunda estrofe como: "Este Inferno, que temos bem visível / E repleto de cenas de ternura" (p.44), enquanto a edição mais recente (2014) corrige "Este Inferno, que temos bem visível / E repleto de cenas de tortura" (p. 44).

Andrade critica a infidelidade da edição de Melhores poemas quanto à disposição gráfica das estrofes e às próprias palavras que compõem os versos de "A triste partida". As sextilhas compostas do poema, até então respeitadas nas demais edições, foram convertidas em oitavas. A mesma reformulação das estrofes foi tomada com as palavras:

Ficou uma verdadeira "traição" ao mais conhecido poema musicado de Patativa. Virou uma paráfrase completa, a língua matuta que tanta autenticidade dá ao poema foi "corrigida" para a norma culta, em várias passagens, a métrica foi violentada pela troca de palavras por outras sinônimas, desmanchando aliterações e assonâncias, tirando inteiramente o sabor e desfigurando o sentido e a sonoridade original do poema (2008, p. 40-41).

Setembro passou, com oitubro e novembro, Já tamo em dezembro.

Meu Deus, que é de nóis?

${ }^{20}$ (PATATIVA DO ASSARÉ. Melhores poemas: Patativa do Assaré. São Paulo: Global, 2006b, p. 166). 
Assim fala o pobre do seco Nordeste,

Com medo da peste,

Da fome feroz.

A treze do mês ele fez a experiença,

Perdeu sua crença

Nas pedra de sá.

Mas nôta experiença com gosto se agarra,

Pensando na barra

Do alegre Natá. ${ }^{21}$

Passou-se setembro, outubro e novembro, estamos em dezembro, meu Deus que é de nós? assim diz o pobre do seco Nordeste com medo da peste e da fome feroz.

A treze do mês fez a experiência, perdeu sua crença nas pedras de sal com outra experiência de novo se agarra, esperando a barra do alegre Natal. ${ }^{22}$

Outro poema problemático é "Cante lá que eu canto cá", pois enquanto a edição de Inspiração nordestina apresenta-se em décimas, no livro que dá nome ao poema, observamos estrofes mistas. Por algum motivo, apenas a primeira estrofe foi dividida em quadra e sextilha:

Poeta, cantô de rua,

Que na cidade nasceu,

Cante a cidade que é sua,

Que eu canto o sertão que é meu.

Se aí você teve estudo,

Aqui, Deus me ensinou tudo,

Sem de livro precisá

Por favô, não mêxa aqui,

Que eu também não mexo aí,

Cante lá, que eu canto cá ${ }^{23}$.

${ }^{21}$ (PATATIVA DO ASSARÉ. Inspiração nordestina. São Paulo: Hedra, 2006a, p. 51).

22 (PATATIVA DO ASSARÉ. Melhores poemas: Patativa do Assaré. São Paulo: Global, 2006b, p. 223).

${ }^{23}$ (PATATIVA DO ASSARÉ. Cante lá que eu canto cá. Petrópolis: Vozes, 2014, p. 25). 
Em resumo, há graves problemas com as edições da obra patativana, como erros de digitação: "Mediante a sua instrução / Naquela scociedade / Reinava paz e união"

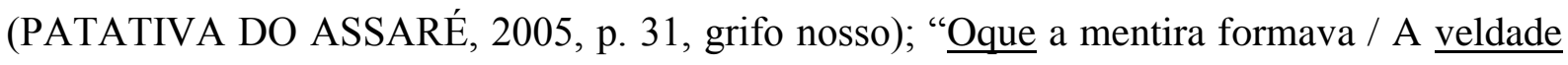
desfazia" (idem, p. 255, grifo nosso); e erros de grafia em poemas de linguagem erudita, majoritariamente presentes em Aqui tem coisa (2012a): "ainda hoje perdura / a beleza de cultura / do Doutor Leonardo Mota, / conferencista exelente" (PATATIVA DO ASSARÉ, 2012a, p. 59, grifo nosso), “Te forneço as imagens ecelentes / No perfil da mulher que tu descreves" (idem, p.81, grifo nosso), "E passa a vida sem gozar socego / sem esquecer o seu torrão natal" (idem, p. 57, grifo nosso), "Eu vivo bastante socegado / Aqui na segunda vida" (idem, p. 197, grifo nosso), "E estou bastante ancioso / Esperando por você" (idem, p. 197, grifo nosso), "Garoto eu desejo que invez deste inferno / Tu tenhas caderno" (idem, p. 11, grifo nosso), "Nosso querido escritor / com um cuidado sem par / foi grande pesquizador" (idem, p. 62, grifo nosso), “A minha vida é tão boa / Que eu não precizo latir” (idem, p. 198, grifo nosso), "Da nossa grande fartura / Carne, limguiça e fartura" (idem, p. 198, grifo nosso), "Nimguém sabe segredo de mulher / e por isto eu pergunto de hora em hora" (idem, p. 65, grifo nosso).

Com base nas discussões apresentadas até o presente capítulo, pode-se inferir que há uma perspectiva de engajamento social evidente na poética patativana. O objetivo no terceiro momento da pesquisa é investigar como o engajamento social emerge nos poemas de Patativa do Assaré e quais espaços histórico-culturais esse sujeito poético apresenta. Desse modo, o propósito é analisar as relações entre literatura e sociedade, com ênfase na discussão sobre o lugar e o papel do intelectual, a partir da análise de seis poemas de Patativa do Assaré, a saber, "A terra é naturá", "A triste partida", "Brasi de cima e Brasi de baxo", "O Inferno, o Purgatório e o Paraíso", “A lição do pinto” e, por fim, "O agregado e o operário”. 
CAPÍTULO 3 - ANÁLISE DOS POEMAS 


\subsection{A TERRA É NATURÁ}

01 Sinhô dotô, meu ofiço 02 É servi ao meu patrão. 03 Eu não sei fazê comiço, 04 Nem discuço, nem sermão; $05 \mathrm{Nem}$ sei as letra onde mora, 06 Mas porém, eu quero agora 07 Dizê, com sua licença, 08 Uma coisa bem singela, 09 Que a gente pra dizê ela 10 Não percisa de sabença.

11 Se um pai de famia honrado, 12 Morre, dexando a famia, 13 Os seus fiinho adorado 14 Por dono da moradia, $15 \mathrm{E}$ aqueles irmão mais véio, 16 Sem pensá nos Evangéio, 17 Contro os novo a toda hora 18 Lança da inveja o veneno 19 Inté botá os mais pequeno 20 Daquela casa pra fora.

21 Disso tudo o resurtado 22 Seu dotô sabe a verdade, 23 Pois, logo os prejudicado 24 Recorre às oturidade; 25 E no chafurdo infeliz 26 Depressa vai o juiz 27 Fazê. a paz dos irmão 28 E se ele fô justicêro 29 Parte a casa dos herdêro 30 Pra cada quá seu quinhão.
31 Seu dotô, que estudou munto

$32 \mathrm{E}$ tem boa inducação,

33 Não ignore este assunto

34 Da minha comparação,

35 Pois este pai de famia 36 É o Deus da Soberania, 37 Pai do sinhô e pai meu, 38 Que tudo cria e sustenta, 39 E esta casa representa 40 A terra que Ele nos deu.

$41 \mathrm{O}$ pai de famia honrado, 42 A quem tô me referindo, 43 É Deus nosso Pai Amado 44 Que lá do Céu tá me uvindo, 45 O Deus justo que não erra 46 E que pra nós fez a terra, 47 Este praneta comum; 48 Pois a terra com certeza 49 É obra da natureza 50 Que pertence a cada um.

\section{Esta terra é como o Só}

52 Que nace todos os dia 53 Briando o grande, o menó $54 \mathrm{E}$ tudo que a terra cria. $55 \mathrm{O}$ só quilarêa os monte, 56 Tombém as água das fonte, 57 Com a sua luz amiga, 58 Potrege, no mesmo instante, 59 Do grandaião elefante 60 A pequenina formiga. 
61 Esta terra é como a chuva,

62 Que vai da praia a campina,

63 Móia a casada, a viúva,

64 A véia, a moça, a menina.

65 Quando sangra o nevuêro,

66 Pra conquistá o aguacêro

67 Ninguém vai fazê fuxico,

68 Pois a chuva tudo cobre,

69 Móia a tapera do pobre

$70 \mathrm{E}$ a grande casa do rico.

71 Esta terra é como a lua,

72 Este foco prateado

73 Que é do campo até a rua,

74 A lampa dos namorado;

75 Mas, mesmo ao véio cacundo,

76 Já com ar de moribundo

77 Sem amô, sem vaidade,

78 Esta lua cô de prata

79 Não lhe dêxa de sê grata;

90 Lhe manda quilaridade.

81 Esta terra é como o vento,

$82 \mathrm{O}$ vento que, por capricho

83 Assopra, as vez, um momento,

84 Brando, fazendo cuchicho.

85 Otras vez, vira o capêta,

86 Vai fazendo piruêta,

87 Roncando com desatino,

88 Levando tudo de móio

89 Jogando arguêro nos óio

90 Do grande e do pequenino.
91 Se o orguiôso podesse

92 Com seu rancô desmedido,

93 Tarvez até já tivesse

94 Este vento repartido,

95 Ficando com a viração

96 Dando ao pobre o furacão;

97 Pois sei que ele tem vontade

$98 \mathrm{E}$ acha mesmo que percisa

99 Gozá de frescô da brisa,

100 Dando ao pobre a tempestade.

101 Pois o vento, o só, a lua,

102 A chuva e a terra também,

103 Tudo é coisa minha e sua,

104 Seu dotô conhece bem.

105 Pra se sabê disso tudo

106 Ninguém precisa de istudo;

$107 \mathrm{Eu}$, sem escrevê nem lê,

108 Conheço desta verdade,

109 Seu dotô, tenha bondade

110 De uvi o que vô dizê.

111 Não invejo o seu tesoro,

112 Sua mala de dinhêro

113 A sua prata, o seu ôro

114 o seu boi, o seu carnêro

115 Seu repôso, seu recreio,

116 Seu bom carro de passeio,

117 Sua casa de morá

$118 \mathrm{E}$ a sua loja surtida,

119 O que quero nesta vida

120 É terra pra trabaiá. 
121 Iscute o que tô dizendo,

122 Seu dotô, seu coroné:

123 De fome tão padecendo

124 Meus fio e minha muié.

125 Sem briga, questão nem guerra,

126 Meça desta grande terra

127 Umas tarefa pra eu!

128 Tenha pena do agregado

129 Não me dêxe deserdado

130 Daquilo que Deus me deu.

Poema presente em diferentes livros, Inspiração nordestina, Cante lá que eu canto cá e Aqui tem coisa, "A terra é naturá", como o próprio título sugere, foi composto na linguagem popular, ou como Patativa preferia nomear, na "linguagem matuta". As estrofes em décimas tipo A ( $a b a b c c d e e d$ ), seguindo a definição de Claudio Andrade em sua tese Aspectos $e$ impasses da poesia de Patativa do Assaré, têm primazia em sua obra. Apesar de contabilizarmos 109 poemas do Tipo A, enquanto constam 157 do Tipo B, os "que seguem o primeiro esquema, são poemas longos com muitas estrofes, já os do Tipo B, são quase todos relativos à glosa de motes, cerca de 130 deste total consistem em uma só estrofe" (2009, p. 114).

No que concerne à metrificação, os versos apresentam-se como heptassílabos (sete sílabas métricas). Também conhecido como redondilha maior, este se constitui como o metro mais popular da tradição literária em língua portuguesa.

"A terra é naturá" contrapõe duas figuras: o sujeito poético, que se pode supor um trabalhador com pouca instrução - “(...) meu ofício / é servi ao meu patrão / Eu não sei fazê comiço, / Nem discuço, nem sermão; / Nem sei as letra onde mora (v. 1-5) - e o "sinhô dotô", seu interlocutor que “(...) estudou munto / e tem boa inducação” (v.31-32).

Apesar do pouco estudo, o sujeito poético deseja passar uma mensagem, já que, segundo ele, a verdade não demanda escolaridade. Como já mencionado, Patativa do Assaré sempre afirmou que a verdade está naquilo que ele chama de "livro da Natureza", isto é, na vida simples do camponês com suas tradições, crenças e valores.

A verdade por todos compartilhada, tendo em vista sua obviedade, refere-se à divisão igualitária de terras. Para o sujeito poético, a terra é obra da natureza que, assim como o sol, a chuva, a lua e o vento, pertence a todos. Observa-se então uma forte referência religiosa para 
demonstrar que a terra é um bem comum: "O Deus justo que não erra / E que pra nós fez a terra, / Este praneta comum; / Pois a terra com certeza / É obra da natureza / Que pertence a cada um" (v.45-50).

A questão da distribuição de terra, a qual é altamente concentrada, é com frequência debatida na obra patativana. Em "A terra é nossa", por exemplo, novamente a reforma agrária é respaldada por alguns valores e ensinamentos cristãos. Entretanto, diferente de "A terra é naturá", o poema apresenta-se na linguagem erudita, confirmando que Patativa do Assaré sempre transitou entre as duas modalidades, ainda que a temática seja a mesma:

Deus fez a grande natura

Com tudo quanto ela tem,

Mas não passou escritura

Da terra para ninguém.

Se a terra foi Deus quem fez

Se é obra da Criação,

Deve cada camponês

Ter uma faixa de chão ${ }^{24}$.

Posteriormente, o sujeito poético de "A terra é naturá" enumera diversos bens do seu interlocutor, esclarecendo que estes não lhe interessam, mas apenas a terra para trabalhar. A sequência massiva de pronomes possessivos evidencia a disparidade social entre os dois: “(...) seu tesoro, / Sua mala de dinhêro / A sua prata, o seu ôro / o seu boi, o seu carnêro / Seu repôso, seu recreio, / Seu bom carro de passeio, / Sua casa de morá / E a sua loja surtida" (v. 111-118).

Ao fim, somente na última estrofe, o trabalhador com pouca instrução revela que seu interlocutor "sinhô dotô" é um coronel: "Iscute o que tô dizendo, / Seu dotô, seu coroné" (v.121 e 122). Desse modo, Patativa do Assaré apresenta, ao longo do poema, temas caros ao Nordeste, como o latifúndio e o coronelismo.

O poeta social critica a proteção dada pelo Estado em relação ao latifúndio, o qual explora uma mão de obra extremamente barata na agricultura, passível de descarte a qualquer momento, principalmente, com a vinda da seca:

Com o flagelo horroroso,

Com o grande desacato, Infiel e impiedoso,

Aquele patrão ingrato,

${ }^{24}$ (PATATIVA DO ASSARÉ. Ispinho e fulô. São Paulo: Hedra,2005, p. 132). 


\section{Com quem declara guerra, \\ Expulsa de sua terra \\ Seu morador camponês, \\ O caboclo flagelado, \\ Seu inditoso agregado \\ Que tanto favor lhe fez ${ }^{25}$.}

Sabe-se que certas medidas do Governo Federal perpetuam o tipo de organização econômica existente, entre elas fornecer verbas para a construção de açudes. Além disso, por muito tempo, o latifundiário exigiu do governo que abrisse "frentes de trabalho" e empregasse a população vítima das secas perto dos locais de trabalho nas épocas de calamidade, assim se evitava a dispersão dessa mão de obra e pouco alterava a situação precária do trabalhador rural.

Enquanto o fenômeno das secas e a baixa produtividade das terras no sertão se configuram como problema de sobrevivência para o sertanejo, os proprietários de terra são favorecidos no período de menor atividade em suas terras, já que não precisam pagar os salários para os trabalhadores parados:

\footnotetext{
No momento, o proprietário relapso das bacias de irrigação tudo recebe do DNOCS e nada dá em troca à Nação. O sistema é perfeito. O proprietário, que não é desapropriado, valoriza, recebendo água do governo, sua terra em 100\%. Não paga salário mínimo a ninguém, usando, como um paxá, da mão-de-obra abundante e barata. Quando há seca, manda seus operários ganhar dinheiro no DNOCS, nas chamadas obras de "emergência". Acabada a "emergência" o DNOCS restitui ao proprietário esses "braços" (CALLADO, 1960, p. 57) ${ }^{26}$.
}

Na visão de Patativa do Assaré, a única solução para esse quadro de exploração e de miséria seria a reforma agrária. Ao fim do poema analisado, sabemos que o sujeito poético é um agregado, figura recorrente na poética patativana: "Tenha pena do agregado / Não me dêxe deserdado / Daquilo que Deus me deu" (v.128-130). O agregado é aquele deserdado da terra, morando de favor na propriedade do outro, nesse caso, o coronel. Com baixo poder aquisitivo, o agregado se vê obrigado a satisfazer seu consumo no próprio armazém da propriedade, o que gera uma dependência por endividamento perene com o patrão. Em "O agregado", presente em Inspiração nordestina e Cante lá que eu canto cá, o poeta retrata o padecer desse homem, cuja única esperança é na providência divina:

\footnotetext{
${ }^{25}$ (PATATIVA DO ASSARÉ. Cante lá que eu canto cá. Petrópolis: Vozes, 2014, p. 326).

${ }^{26}$ DNOCS - Departamento Nacional de Obras Contra as Secas.
} 
Acorda bem cedo e do frio agasaio

Sai para o trabaio, de foice ou de enxada;

Assim padecendo crué abandono

Na roça do dono da casa caiada

Não crê nas promessa do rico pulento,

No seu sofrimento só pensa em Jesus,

Rogando e pedindo pra tê piedade,

Levando a metade do peso da cruz ${ }^{27}$.

Patativa do Assaré, entretanto, acredita na possibilidade de mudança dessa injusta vida do agregado através da luta. O soneto intitulado "Reforma agrária" apresenta como interlocutor o próprio agregado, tido como amigo do sujeito poético:

Pobre agregado, força de gigante,

Escuta amigo o que te digo agora,

Depois da treva vem a linda aurora

E a tua estrela surgirá brilhante.

$$
\text { [...] }
$$

Lutai altivo, corajoso e esperto

Pois só verás o teu país liberto

Se conseguires a reforma agrária. ${ }^{28}$

O poeta sempre se colocou ao lado dos menos favorecidos, notadamente o sertanejo, e revelou a importância da reforma agrária para o camponês. Para o poeta matuto, a reorganização da estrutura fundiária mostrar-se-ia uma grande medida para a igualdade social. Nesse sentido, no poema "Eu quero", o sujeito poético lista seus anseios pela pátria, entre eles a redistribuição das propriedades rurais, que representaria o fim da penosa vida do homem do campo:

\footnotetext{
A bem do nosso progresso,

Quero o apoio do congresso

Sobre uma reforma agrária

Que venha por sua vez

Libertar o camponês

Da sua situação precária. ${ }^{29}$
}

\footnotetext{
27 (PATATIVA DO ASSARÉ. Cante lá que eu canto cá. Petrópolis: Vozes, 2014, p.340).

28 (PATATIVA DO ASSARÉ. Ispinho e fulô. São Paulo: Hedra, 2005, p.197).

29 (PATATIVA DO ASSARÉ. Cante lá que eu canto cá. Petrópolis: Vozes, 2014, p.116).
} 
Outro poema sobre a distribuição mais justa das terras encontra-se em Aqui tem coisa. "Reforma agrária é assim" apresenta a necessidade da luta e da união do camponês sem terra para alcançar o fim do latifúndio. Como sempre, o sujeito poético coloca-se como integrante da luta, como se pode reconhecer pelo uso contínuo da primeira pessoa do plural em "a gente" e "nós":

Era só o que fartava, Deus fez a terra pra gente prantá feijão, mio e fava, arroz e toda semente, e estes latifundiaro egolsta e uzuraro [sic] sem que nem praque se apossa, e nós neste cativêro sendo agregara e rendero [sic] da mesma terra que é nossa.

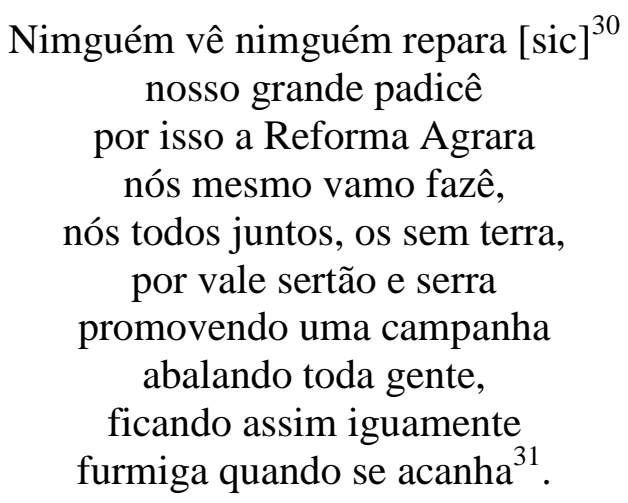

No poema "A terra é naturá", o sujeito poético menciona a fome como o grande padecer do pobre agregado. Apesar de todo sofrimento, esse não deseja guerra com o latifundiário e pede somente um pouco de terra para trabalhar. Logo, não há grandes ambições em Patativa, o que o poeta demanda é o mínimo de dignidade e de direitos ao agregado: "De fome tão padecendo / Meus fio e minha muié. / Sem briga, questão nem guerra, / Meça desta grande terra / Umas tarefa pra eu!"' (v. 123-127).

Em "A terra é nossa" - poema já mencionado aqui -, o sujeito poético menciona a questão da luta por terra que ocorre desde os primórdios de nossa história. Para ele, não há razão para brigas, pois a terra é um bem comum. Além disso, a guerra sempre garantiu a vitória daqueles que detinham o poder, enquanto o desvalido perde com a própria vida:

\footnotetext{
${ }^{30}$ Como já mencionado, essa edição de Aqui tem coisa apresenta inúmeros problemas de digitação.

31 (PATATIVA DO ASSARÉ. Aqui tem coisa. São Paulo: Hedra, 2012a, p.42).
} 
Faz pena ver sobre a terra

O sangue humano correr

O grande provoca guerra

Para o pequeno morrer.

Vive o mundo sempre em guerra

Ambicioso e sanhudo,

Tudo brigando por terra

E a terra comendo tudo ${ }^{32}$.

A utopia patativana não é de abundância, como é no cordel; o poeta matuto acredita na relevância da vida simples e luta para que todos, assim como ele, tenham sua própria terra para não ser subjulgado por um patrão. Nesse sentido, pode-se citar o mote "Viva o povo brasileiro", presente no livro Aqui tem coisa:

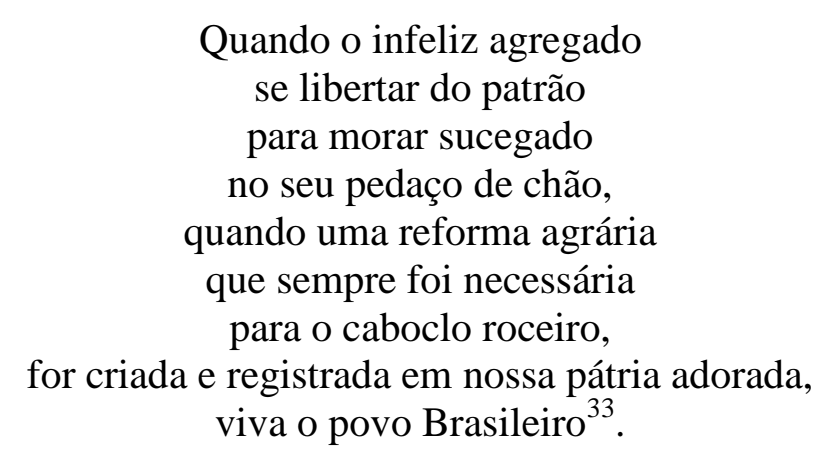

Pode-se aqui citar os versos de "Resposta de patrão", poema cantado após seu sobrinho Geraldo Gonçalves de Alencar compor "Pergunta de moradô", no qual o agregado pergunta a seu patrão o que este faria no lugar do pobre trabalhador:

Tenho fazenda de gado,

Tenho grande agricultura

E é à custa do agregado

Que eu faço grande fartura,

Toda vida eu me preparo

Para sempre vender caro

E sempre comprar barato

E o voto dos eleitores,

Que são os meus moradores

Eu vendo ao meu candidato ${ }^{34}$.

\footnotetext{
32 (PATATIVA DO ASSARÉ. Ispinho e fulô. São Paulo: Hedra, 2005, p.132).

${ }^{33}$ (PATATIVA DO ASSARÉ. Aqui tem coisa. São Paulo: Hedra, 2012a, p. 56).

34 (PATATIVA DO ASSARÉ. Ispinho e fulô. São Paulo: Hedra, 2005, p. 128).
} 
Sempre se acreditou que o grande problema do Nordeste era a limitação da disponibilidade de água, concentrando-se, então, grandes esforços no represamento da mesma. Entretanto, hoje se sabe que a escassez de água é apenas um dos componentes do problema, pois a questão fundiária é igualmente fundamental. Nesse sentido, a poética patativana desempenha um relevante papel de representação daqueles que foram explorados pela política repressora e injusta do sertão brasileiro, a qual desencadeia a desigualdade social. O poeta social denuncia a alta concentração de renda e de propriedade que não é exclusividade dos grandes centros urbanos. 


\subsection{A TRISTE PARTIDA}

1 Setembro passou, com oitubro e novembro

2 Já tamo em dezembro.

3 Meu Deus, que é de nóis?

4 Assim fala o pobre do seco Nordeste,

5 Com medo da peste,

$6 \mathrm{Da}$ fome feroz.

7 A treze do mês ele fez a esperiença,

8 Perdeu sua crença

9 Nas pedra de sá.

10 Mas nôta esperiença com gosto se agarra,

11 Pensando na barra

12 Do alegre Natá.

13 Rompeu-se o Natá, porém barra não vêio, 14 O só, bem vermêio,

15 Nasceu munto além.

$16 \mathrm{Na}$ copa da mata, buzina a cigarra,

17 Ninguém vê a barra,

18 Pois barra não tem.

19 Sem chuva na terra descamba janêro,

20 Depois feverêro,

21 E o mêrmo verão

22 Entonce o rocêro, pensando consigo,

23 Diz: isso é castigo!

24 Não chove mais não!

25 Apela p'ra maço, que é o mês preferido 26 Do Santo querido,

27 Senhô São José.

28 Mas nada de chuva! Tá tudo sem jeito,

29 Lhe foge do peito

$30 \mathrm{O}$ resto da fé.
31 Agora pensando segui ôtra tria,

32 Chamando a famía

33 Começa a dizê:

34 Eu vendo meu burro, meu jegue e o cavalo, 35 Nóis vamo a Sã Palo

36 Vivê ou morrê.

37 Nóis vamo a Sã Palo, que a coisa tá feia;

38 Por terras alêia

39 Nóis vamo vagá.

40 Se o nosso destino não fô tão mesquinho,

41 Pro mêrmo cantinho

42 Nóis torna a vortá.

43 E vende o seu burro, o jumento e o cavalo, 44 Inté mêrmo o galo

45 Vendêro também,

46 Pois logo aparece feliz fazendêro,

47 Por pôco dinhêro

48 Lhe compra o que tem.

49 Em riba do carro se junta a famia;

50 Chegou o triste dia,

51 Já vai viajá.

52 A sêca terrive, que tudo devora,

53 Lhe bota pra fora

54 Da terra natá.

$55 \mathrm{O}$ carro já corre no topo da serra.

56 Oiando pra terra,

57 Seu berço, seu lá,

58 Aquele nortista, partido de pena,

59 De longe inda acena:

60 Adeus, Ceará! 
61 No dia seguinte, já tudo enfadado,

62 E o carro embalado,

63 Veloz a corrê,

64 Tão triste, o coitado, falando saudoso,

$65 \mathrm{Um}$ fio choroso

66 Escrama, a dizê:

67 - De pena e sodade, papai, sei que morro!

68 Meu pobre cachorro,

69 Quem dá de comê?

70 Já ôto pergunta: - Mãezinha, e meu gato?

71 Com fome, sem trato,

72 Mimi vai morrê!

73 E a linda pequena, tremendo de medo:

74 - Mamãe, meus brinquedo!

$75 \mathrm{Meu}$ pé de fulô!

76 Meu pé de rosêra, coitado, ele seca!

$77 \mathrm{E}$ a minha boneca

78 Também lá ficou.

79 E assim vão dêxando, com choro e gemido,

80 Do berço querido

81 O céu lindo e azú.

82 Os pai, pesaroso, nos fio pensando,

83 E o carro rodando

$84 \mathrm{Na}$ estrada do Sú.

85 Chegaro em Sã Paulo - sem cobre, quebrado. 86 O pobre, acanhado,

87 Procura um patrão.

88 Só vê cara estranha, da mais feia gente,

89 Tudo é diferente

90 Do caro torrão.
91 Trabaia dois ano, três ano e mais ano,

92 E sempre no prano

93 De um dia inda vim.

94 Mas nunca ele pode, só véve devendo, $95 \mathrm{E}$ assim vai sofrendo

96 Tromento sem fim.

97 Se arguma notícia das banda do Norte

98 Tem ele por sorte

99 O gosto de uvi,

100 Lhe bate no peito sodade de moio,

101 E as água dos óio

102 Começa a caí.

103 Do mundo afastado, sofrendo desprezo,

104 Ali véve preso,

105 Devendo ao patrão.

106 O tempo rolando, vai dia vem dia,

107 E aquela famia

108 Não vorta mais não!

109 Distante da terra tão sêca tão boa,

110 Exposto à garoa,

111 À lama e ao paú,

112 Faz pena o nortista, tão forte, tão bravo,

113 Vivê como escravo

114 Nas terra do Sú. 
Gravado musicalmente por Luiz Gonzaga, no disco "Homem da terra”, em 1964, "A triste Partida”, que vale destacar é o poema de maior divulgação da obra patativana, lançou o poeta matuto comercialmente. A canção alcançou o maior sucesso entre os migrantes nordestinos, pois, assim como toda discografia de Gonzaga, ela:

[...] se conecta com a saudade do lugar de origem, com o medo da cidade grande e, ao mesmo tempo, com o orgulho de estar enfrentando-a, com seus valores de origem rural como a religiosidade e a importância dos laços familiares (ALBUQUERQUE JR, 2009, p. 178).

Hoje, como referência para muitos que bebem da fonte da literatura popular, os versos de "A triste partida" retratam a saída do sertanejo de sua terra e a busca de sobrevivência no Sul. Tal realidade dramática já presente na literatura erudita, é, no entanto, aqui renovada por Patativa do Assaré ao trazer uma linguagem autêntica, dando voz a esse caboclo, que fora tantas vezes oprimido pelo próprio narrador culto e literato.

Em "A triste partida", Patativa retrata o sofrimento do matuto e adapta a história do povo à linguagem popular. O poema apresenta-se na variante matuta, visto a nãoconcordância presente em "dois ano, três ano", supressão do [1] final em "natá", supressão do [r] final em "senhô", troca do fonema [1] pelo [r] em "vorta"; redução da semi-vogal dentro do vocábulo em "dinhêro", supressão do /lh/ em "vermêio", mudança de posição do fonema [r] dentro do vocábulo, como "tromento"; redução de fonemas para aproximar-se da oralidade popular como "tamo", acréscimo de fonemas para aproximar-se da linguagem popular “despois"; além de léxicos típicos do falar caipira "entonce", “inté” e "em riba".

Nesses versos, o poeta denuncia a cruel realidade do trabalhador rural, o qual é obrigado a se deslocar de sua terra natal por conta da negligência do Estado em relação à região nordestina. Sabemos que o descaso social é a tônica de sua poética, tendo em vista versos como “A morte de Nanã”, cujo vilão não é a seca, mas o rico patrão:

Mas, neste mundo de Cristo,

Pobre não pode gozá.

Eu, quando me lembro disto,

Dá vontade de chorá.

Quando há seca no sertão,

Ao pobre falta feijão,

Farinha, milho e arroz.

Foi isso que aconteceu:

A minha filha morreu,

$\mathrm{Na}$ seca de trinta e dois. 


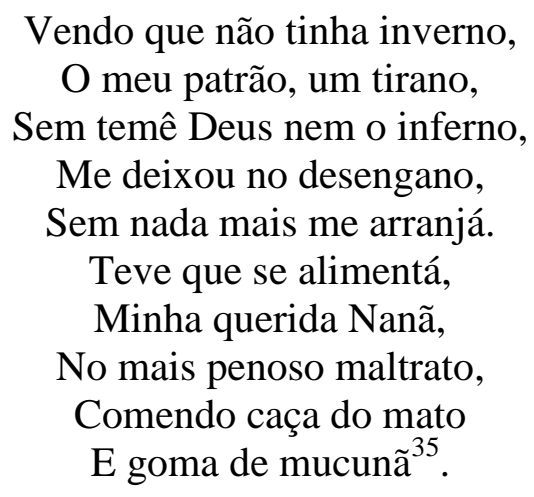

E ainda "A política", que demonstra como os governantes, após a vitória eleitoral, ignoram o flagelo do povo nordestino:

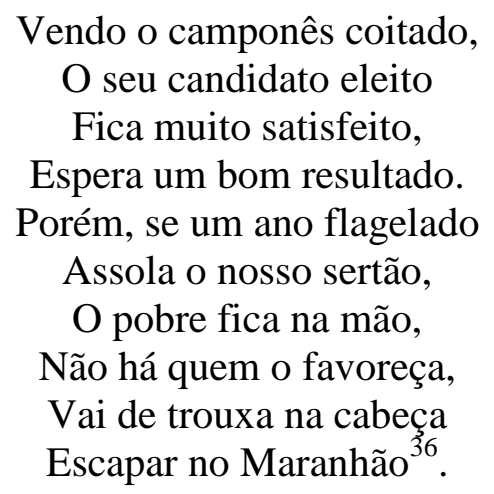

"A triste partida" traz a história do sertanejo que se vê obrigado a abandonar seu torrão natal por conta da seca, a qual não lhe dá condições de sobrevivência. Apesar de o sujeito poético narrar a diáspora da seca que sofre o nordestino, em alguns momentos, ficamos diante dos desabafos do próprio sertanejo a partir do discurso direto. Nesses versos, observa-se como o sujeito poético busca dar o direito de voz ao sertanejo: “Agora pensando segui ôtra tria, / Chamando a famía / Começa a dizê: / Eu vendo meu burro, meu jegue e o cavalo, / Nóis vamo a Sã Palo / vivê ou morrê" (v. 31-36). Nesse contexto, ao partir para o Sul, observa-se que a cidade representa o ambiente de exílio: "Do mundo afastado, sofrendo desprezo, / Ali véve preso, / Devendo ao patrão. / O tempo rolando, vai dia vem dia, / E aquela famia / Não vorta mais não!" (v. 103-108).

A narrativa do drama da diáspora nordestina é constante na obra patativana, entretanto, nesse citado poema, o sujeito poético não chega a abordar, de forma detalhada, a vida do sertanejo na urbe: "Distante da terra tão sêca tão boa, / Exposto à garoa, / À lama e ao paú, /

\footnotetext{
35 (PATATIVA DO ASSARÉ. Cante lá que eu canto cá. Petrópolis: Vozes, 2014, p. 43).

${ }^{36}$ (PATATIVA DO ASSARÉ. Inspiração nordestina. São Paulo: Hedra, 2006a, p. 234).
} 
Faz pena o nortista, tão forte, tão bravo, / Vivê como escravo / Nas terra do Sú” (v. 109- 114).

Diferentemente do que ocorre em "Emigrante nordestino no Sul do país":

O carro corre apressado

E lá no Sul faz despejo,

Deixando desabrigado

O flagelado cortejo,

Que a procura de socorro

Uns vão viver pelo morro

Num padecer sem desconte,

Outros pobres infelizes

Se abrigam sob as marquises,

E outros por baixo da ponte.

Rompendo mil impecilhos,

Nisto tudo o que é pior,

É que o pai tem oito filhos

E cada qual é menor.

Aquele homem sem sossego,

Mesmo arranjando um emprego

Nada pode resolver,

Sempre na penúria está

Pois o seu ganho não dá

Para a família manter ${ }^{37}$.

Também “O nordestino em São Paulo”, que retrata essa realidade:

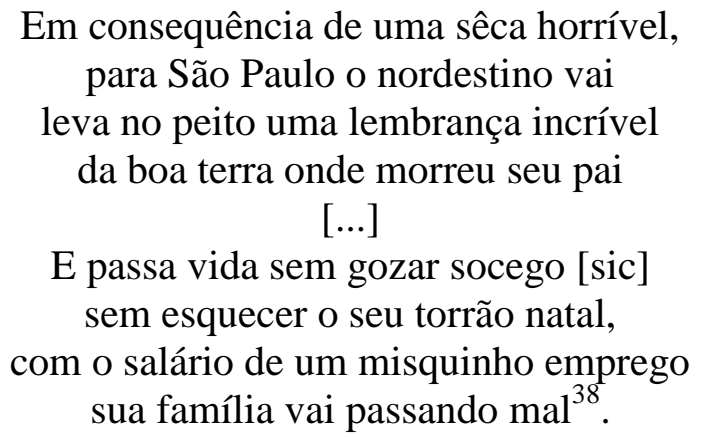

O nordestino em diáspora luta por melhores condições de vida e assim se forma uma legião de mão de obra barata e descartável nos grandes centros urbanos. A urbe surge para o retirante a partir do despejo, pois o sertanejo foge da pauperização imposta pela seca do Norte e, por fim, acaba marginalizado no Sul. A cidade não se mostra um ambiente acolhedor,

37 (PATATIVA DO ASSARÉ. Cante lá que eu canto cá. Petrópolis: Vozes, 2014, p. 327).

${ }^{38}$ (PATATIVA DO ASSARÉ. Aqui tem coisa. São Paulo: Hedra, 2012a, p. 57). 
apenas condena o nordestino à exploração, ao lugar periférico e ao espaço da indigência. $\mathrm{O}$ otimismo com relação à megalópole logo é substituído pela realidade dura das ruas ou das periferias.

Já no início de "A triste partida", observamos como o sujeito poético constrói a caracterização do Nordeste, diante das imagens da seca: "só" (v. 14), "vermêio" (v. 14), "verão" (v. 21). A região é marcada pela combinação de significantes negativos, como "pobre" (v. 4), "seco" (v. 4), "medo" (v. 5), "peste" (v. 5) e "fome” (v. 6), e do emprego das negações "sem chuva" (v. 19), "não chove" (v. 24) e "nada de chuva” (v. 28).

Como de costume, traços religiosos são trazidos para evocar a fé do nordestino e sua importância no Nordeste: “Apela p'ra maço, que é o mês preferido / Do Santo querido, / Senhô São José. / Mas nada de chuva! Tá tudo sem jeito, / Lhe foge do peito / O resto da fé" (v. 25-30). No entanto, da mesma forma que essa fé foge do peito do nordestino, o próprio acabará por fugir do seu berço natal.

O sujeito poético, a partir da fuga do sertão, descreve cada membro da família. Acompanhando as imagens que compõem os filhos, sempre tristes, saudosos e chorosos, Patativa dá-lhes voz e cada um menciona as poucas "posses" que a família nordestina deixou para trás. Vale observar que não se referem a posses materiais, visto que constantemente o caboclo é descrito como "sem cobre", "quebrado" e "pobre".

$\mathrm{Na}$ oitava estrofe, o sujeito poético compõe a imagem da seca como antagonista, da mesma forma como fizera Graciliano Ramos, em Vidas Secas. Apesar de Patativa do Assaré não mencionar a obra do escritor alagoano entre suas leituras, como já fizera acerca de Castro Alves e Casimiro de Abreu, há grandes similaridades entre a prosa e sua poesia. Assim como havia, em Vidas Secas, o patrão de Fabiano, sujeito desonesto e explorador, o sujeito lírico de "A triste partida" apresenta o fazendeiro, ligado ao "dinhêro" (v. 47), à "compra" (v. 48) e à felicidade (v. 46) à custa da desgraça do pobre caboclo. Além disso, também vale notar a semelhança entre o verso "Ali véve preso" (v. 104) e o famoso desfecho do romance:

Que iriam fazer? Retardaram-se, temerosos. Chegariam a uma terra desconhecida e civilizada, ficariam presos nela. E o sertão continuaria a mandar gente para lá. O sertão mandaria para a cidade homens fortes, brutos, como Fabiano, Sinhá Vitória e os dois meninos (RAMOS, 2002, p. 126).

A seca "terrive" (v. 52) e opressora é personificada, ganhando os verbos de ação "devora" (v. 52), e "bota pra fora" (v. 53), pois é ela que impulsiona a fuga da família sertaneja do Ceará, tido como "terra natá" (v. 54) e "lá" (v. 57). Em outros poemas, no 
entanto, Patativa do Assaré afirma, como já fizeram os estudiosos, que o grande problema da região nordestina não é a seca, mas sim o sistema econômico estruturalmente vulnerável e instável, inadaptado ao meio, tendo em vista a baixa produtividade da economia regional e maior vulnerabilidade da agricultura de subsistência ao fenômeno:

A economia dessa região não está organizada para a seca, que é a exceção. Está toda ela montada como se a seca não existisse. O simples prolongamento do verão, ou atraso do inverno, acarreta sérios transtornos em razão da extrema fragilidade da economia regional (FURTADO, 1962, p. 57).

Até a década de 50, a atuação do Governo Federal no Nordeste se caracterizou como socorro ao flagelo ocasionado pelas secas, portanto, com claro caráter imediatista. Nesse momento, a questão da seca nordestina representava apenas um problema regional. Entretanto, surgiu a necessidade de fixar a população nessa zona, no intuito de frear a invasão dos núcleos urbanos, a qual criava problemas de desemprego e de tensão social. A solução do Governo foi a irrigação realizada através da construção de açudes e barragens, que inicialmente deveriam funcionar como pontos fortificados de resistência à seca no sertão. Ainda assim, faltou pensar a adversidade nordestina como problema econômico e não de engenharia hidráulica:

O combate às secas, através de grandes obras de engenharia, como as projetadas, ou as de emergência, como o que se vai fazer no momento, será sempre improfícuo, se não for acompanhado de elementos capazes de fortalecer a economia regional, mediante o amparo às suas atividades econômicas (COHN, 1978, p. 62).

Com frequência, o Nordeste é visto como uma região fadada à miséria pelas secas, cabendo ao Governo Federal apenas medidas paliativas para reduzir essa calamidade social:

É a seca que chama atenção dos veículos de comunicação, especialmente dos jornais do sul do país, para a existência do Norte e de seus "problemas". Ela é, sem dúvida, o primeiro traço definidor do Norte e o que o diferencia do Sul, notadamente, num momento em que o meio é considerado, ao lado da raça, como fatores determinantes da organização social (ALBUQUERQUE JUNIOR, 2009, p. 81).

Durval Muniz de Albuquerque Junior, em seu livro A invenção do Nordeste e outras artes, demonstra como o Nordeste foi inventado como o "outro" de São Paulo. Segundo o pesquisador, o regional é mais do que um recorte físico ou geográfico; ele nasce de um modo de vida, de uma cultura e de uma sociabilidade específicos. Assim, São Paulo, comumente 
identificado como o Sul, é o espaço-outro contra o qual se pensa a identidade do Nordeste, espaço subalterno na rede de poderes.

A mobilização dos camponeses para os grandes centros urbanos fomenta o fenômeno do subemprego ou mesmo do desemprego nestas regiões. A velha dicotomia entre Norte e Sul, isto é, entre área arcaica e moderna, alimentada pelos canais de informação, possibilita a ilusão de melhores condições de vida, o que impulsiona as ondas de migração para o meio urbano.

Patativa do Assaré, reconhecido como porta-voz do Nordeste, traz, em seus versos, a imagem de São Paulo, na visão do sertanejo, como cidade das oportunidades. No entanto, nota-se como se mantém viva a esperança do seu povo em voltar futuramente para sua terra. Nesse sentido, o poeta descreve a urbe como "terras alêia" (v. 38) e o sertão como "cantinho" (v. 41).

Ao longo de todo poema "A triste partida", a terra natal é descrita de forma afetiva como "berço" de "céu lindo e azú", em contraste com a cidade alheia, "Sã Palo", associada à "cara estranha", "feia gente" e "diferente". No último verso, Patativa revela que, apesar das dificuldades no sertão, o nordestino sempre mantém uma relação afetiva com a sua terra, julgando-a "tão sêca, tão boa" ao mesmo tempo. Seca que se coloca em oposição à garoa, à lama constante nas "terra do Sú". E para findar sua poética, o sujeito lírico valoriza o caboclo com os léxicos "forte" e "bravo", que se contrapõem à vida "mesquinha" que enfrenta e à sua situação constante de "vivê como escravo", explorado no exílio.

A imagem do opressor é trazida pela figura de um "patrão", aquele que explora o pobre retirante nordestino na nova terra e a quem o caboclo "só véve devendo". O sujeito poético revela o processo de desenvolvimento desigual dentro do sistema capitalista, tendo em vista que o Nordeste sempre sofreu com o atraso econômico, tornando-se um fornecedor de mão de obra e de capital para o polo dinâmico da economia, São Paulo.

O sertanejo é constantemente oprimido, entretanto aqui, a opressão não vem do sujeito poético, visto que este lhe dá direito à expressão de suas próprias angústias. Patativa do Assaré quebra o preconceito de que o caboclo não tem voz e pensamento, assim como fizeram os escritores da tradição literária canônica Graciliano Ramos e Guimarães Rosa. Em "Vidas Secas", o narrador buscou revelar que os retirantes, aparentemente brutos e primitivos, também apresentam pensamentos e angústias. Rosa, por sua vez, radicaliza o procedimento de dar voz ao sertanejo, especialmente no romance Grande sertão: veredas, em que o doutor da cidade é reduzido à posição de ouvinte do extenso monológico de Riobaldo. 
A temática do êxodo rural é muito recorrente na poética patativana, trazendo consigo o tema da saudade. O sertanejo do poeta sempre demonstra saudade da terra natal, dos amigos e dos animais. Com a diáspora, o Nordeste é evocado na memória como um sertão mítico a que se quer sempre voltar. Sua poesia saudosista é uma viagem a esse "espaço afetivo" que ficou no passado, marcado pela vida camponesa pacata e alegre. No poema "Vou vorta", por exemplo, o sujeito poético é o migrante que já se alojou na cidade e agora decide voltar para o sertão por duas razões: a não-adaptação aos grandes centros urbanos - ("Eu não gostei do rejume, / Da vida da capitá") 39 - e a saudade da culinária ("Dêrne que eu sai de casa / Nunca mais comi pirão / Mexido em prato de barro, / Como se faz no sertão") ${ }^{40}$, dos amigos e dos animais:

$$
\begin{aligned}
& \text { Já tou com munta sodade } \\
& \text { Lá das minha capoêra, } \\
& \text { Do meu cavalo Peitica } \\
& \text { E da vaca lavadêra, } \\
& \text { De Zefa, minha muié, } \\
& \text { De João, de Chico e José, } \\
& \text { E de tudo, finalmente. } \\
& \text { Vossimincêis não conhece } \\
& \text { O tanto que se padece } \\
& \text { Longe da casa da gente }{ }^{41} \text {. }
\end{aligned}
$$

O sertão patativano é inferno, purgatório, mas também paraíso com seu estilo de vida simples e suas belezas naturais. Terra seca e pedregosa, mas também lugar de brisas e pássaros. Pode-se dizer que se trata de uma visão "católico-sertaneja", na qual bem e mal convivem construindo uma visão totalizadora:

O vento assopra manêro Durante os teus mês de estio, Trazendo um certo tempero Que não faz calo nem frio. E no tempo da invernada Canta alegre a passarada

Cada quá sua canção, E a garça de branca pena Encruza as água serena Do rio dos Bastião ${ }^{42}$.

\footnotetext{
39 (PATATIVA DO ASSARÉ. Cante lá que eu canto cá. Petrópolis: Vozes, 2014, p. 211).

${ }^{40}$ (Ibid., p. 211).

${ }^{41}$ (Ibid., p. 211).

${ }^{42}$ (PATATIVA DO ASSARÉ. Inspiração nordestina. São Paulo: Hedra, 2006a, p. 45).
} 
Nesse sentido, o sertão, para Patativa do Assaré, não é somente miséria, fome e sofrimento, mas também o "cantinho" (2014, p. 210) do nordestino que sempre lhe dá saudade. "O retrato do sertão" é um claro exemplo dessa poesia dialética que valoriza o Nordeste e suas belezas naturais, crenças e valores sertanejos, sem deixar de apontar as problemáticas da região:

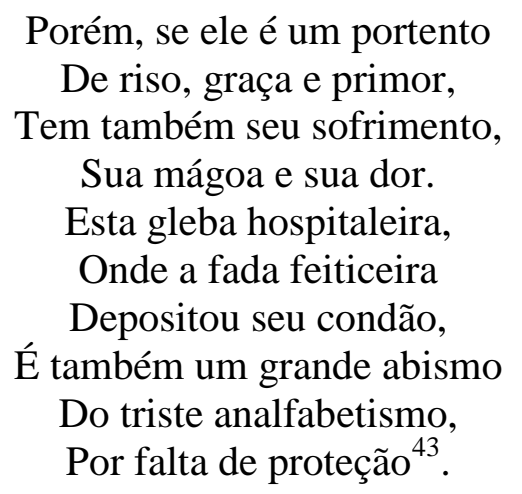

Patativa nos traz inúmeros poemas com a temática da seca, entre eles "ABC do Nordeste flagelado", no qual o sujeito poético descreve detalhadamente as mudanças na natureza com a prolongada ausência da chuva e suas consequências para o povo daquela região. Novamente aqui o sertanejo recorre à migração e, na nova terra, não encontra uma melhor qualidade de vida, mas sim a já conhecida exploração enquanto mão de obra barata:

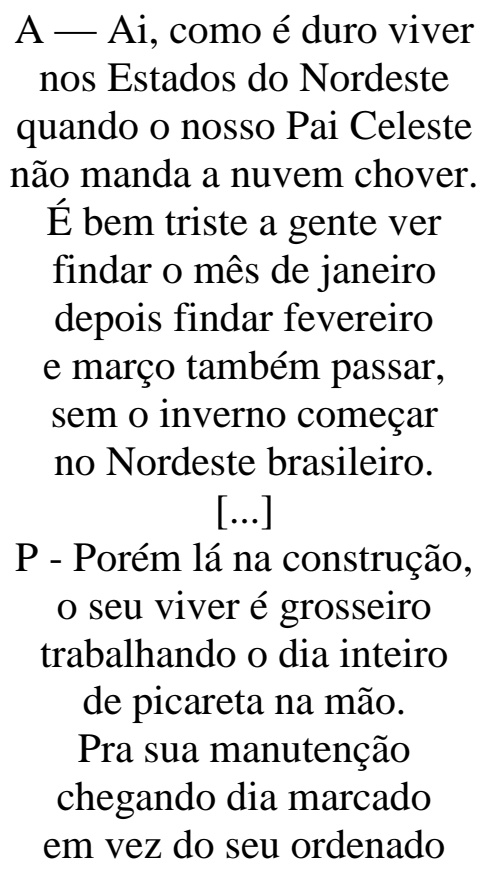

${ }^{43}$ (PATATIVA DO ASSARÉ. Cante lá que eu canto cá. Petrópolis: Vozes, 2014, p. 236). 
dentro da repartição,

recebe triste ração,

farinha e feijão furado $^{44}$.

Apesar de extenso, o poema não questiona a falta de assistência do governo e responsabiliza apenas a natureza pela migração do nordestino. Também não apresenta o fazendeiro como homem oportunista que enriquece com o padecer do agregado, pelo contrário, ambos sofrem juntos:

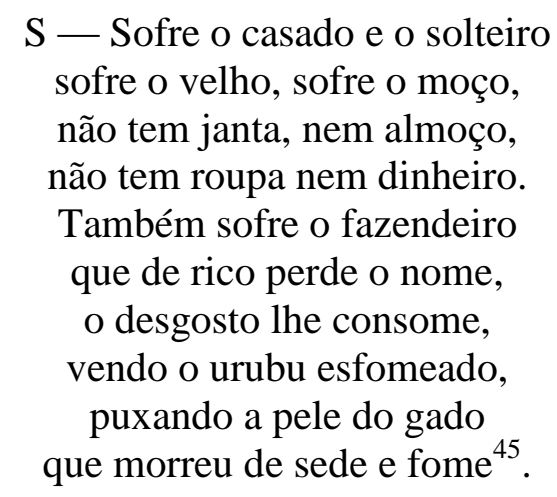

Entretanto, sabe-se que a seca não é o único fator responsável pela migração ruralurbana. São três as maiores causas do êxodo rural no Nordeste: a estiagem, o desemprego e os baixos salários. Tais fatores decorrem da estrutura agrária do Nordeste, marcada pelo predomínio do latifúndio e da baixa remuneração de mão de obra, o que acarreta a alta concentração da renda. Como o processo de crescimento do setor industrial é lento, este mercado de trabalho não consegue absorver o excedente de mão de obra do setor agrário. Surgem então, nos núcleos urbanos, as populações marginais. Nesse contexto, em "Nordestino sim, nordestinado não", o sujeito lírico novamente aborda a questão do êxodo rural, porém explica que a culpa da "legião de retirantes" não é de Deus, mas consequência da "desigualdade política-econômica e social":

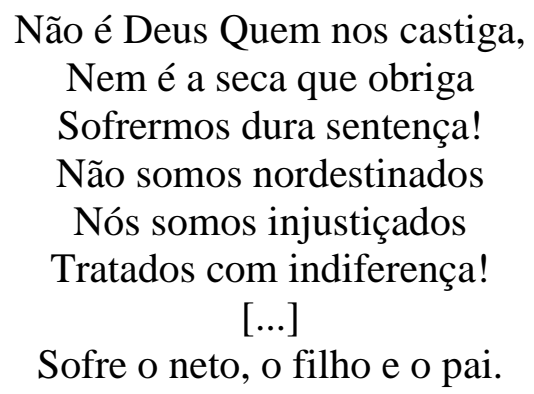

${ }_{45}^{4}$ (PATATIVA DO ASSARÉ. Cante lá que eu canto cá. Petrópolis: Vozes, 2014, p. 308-312).

${ }^{45}$ (Ibid., p. 308-313). 
Para onde o pobre vai, Sempre encontra o mesmo mal.

Esta miséria campeia

Desde a cidade à aldeia,

Do Sertão à capital.

Aqueles pobres mendigos

Vão à procura de abrigos,

Cheios de necessidade.

Nesta miséria tamanha,

Se acabam na terra estranha,

Sofrendo fome e saudade! ${ }^{46}$

Patativa do Assaré, como poeta social, revela, em "A triste partida", a questão da diáspora da seca no Nordeste e a luta desse povo cheio de esperanças e coragem. Em seus versos, aborda a luta e, principalmente, a fé do povo nordestino ao trazer a realidade dramática que este enfrenta, na sua terra natal, com a seca e o fazendeiro, e a chegada, não diferente, à cidade grande, onde é explorado pelo patrão. Dessa maneira, o poema transmite toda a opressão sofrida pelo nordestino ao longo de sua própria história; pressão da "sêca", do "fazendêro", da metrópole e "do patrão". O sertanejo revela-se representante desse Nordeste, cuja estrutura econômica integrada de forma perversa e nula viabilidade de desenvolvimento o faz participar do processo de desenvolvimento brasileiro apenas fornecendo força de trabalho barata para a região Sul, polo dinâmico da economia nacional.

46 (PATATIVA DO ASSARÉ. Ispinho e fulô. São Paulo: Hedra, 2005, p. 38-39). 


\subsection{BRASI DE CIMA E BRASI DE BAXO}

01 Meu compadre Zé Fulô,

$02 \mathrm{Meu}$ amigo e companhêro,

03 Faz quage um ano que eu tou

04 Neste Rio de Janêro;

05 Eu saí do Cariri

06 Maginando que isto aqui

07 Era uma terra de sorte,

08 Mas fique sabendo tu

09 Que a miséria aqui do $\mathrm{Su}$

10 É esta mesma do Norte.

11 Tudo o que procuro acho.

12 Eu pude vê neste crima,

13 Que tem o Brasi de Baxo

14 E tem o Brasi de Cima.

15 Brasi de Baxo, coitado!

16 É um pobre abandonado;

$17 \mathrm{O}$ de Cima tem cartaz,

18 Um do ôtro é bem deferente:

19 Brasi de Cima é pra frente,

20 Brasi de Baxo é pra trás.

21 Aqui no Brasi de Cima,

22 Não há dô nem indigença,

23 Reina o mais soave crima

24 De riqueza e de opulença;

25 Só se fala de progresso,

26 Riqueza e novo processo

27 De grandeza e produção.

28 Porém, no Brasi de Baxo

29 Sofre a feme e sofre o macho

30 A mais dura privação.
31 Brasi de cima festeja

32 Com orquestra e com banquete,

33 De uísque dréa e cerveja

34 Não tem quem conte os rodete.

35 Brasi de Baxo, coitado!

36 Vê das casa despejado

37 Home, menino e muié

38 Sem achá onde morá

39 Proque não pode pagá

$40 \mathrm{O}$ dinhêro do alugué.

41 No Brasi de Cima anda

42 As trombeta em arto som

43 Ispaiando as porpaganda

44 De tudo aquilo que é bom.

45 No Brasi de Baxo a fome

46 Matrata, fere e consome

47 Sem ninguém lhe defendê;

$48 \mathrm{O}$ desgraçado operaro

49 Ganha um pequeno salaro

50 Que não dá pra vivê.

51 Inquanto o Brasi de Cima

52 Fala de transformação,

53 Industra, matéra prima,

54 Descobertas e invenção,

55 No Brasi de Baxo isiste

$56 \mathrm{O}$ drama penoso e triste

57 Da negra necissidade;

58 É uma cousa sem jeito

$59 \mathrm{E}$ o povo não tem dereito

60 Nem de dizê a verdade. 
61 No Brasi de Baxo eu vejo

62 Nas ponta das pobre rua

$63 \mathrm{O}$ descontente cortejo

64 De criança quage nua.

65 Vai um grupo de garoto

66 Faminto, doente e roto

67 Mode caçá o que comê

68 Onde os carro põe o lixo,

69 Como se eles fosse bicho

70 Sem direito de vivê.

71 Estas pequenas pessoa,

72 Estes fio do abandono,

73 Que veve vagando à toa

74 Como objeto sem dono,

75 De manêra que horroriza,

76 Deitado pela marquiza,

77 Dromindo aqui e açula

78 No mais penoso relaxo,

79 É deste Brasi de Baxo

80 A crasse dos marginá.

81 Meu Brasi de Baxo, amigo,

82 Pra onde é que você vai?

83 Nesta vida do mendigo

84 Que não tem mãe nem tem pai?

85 Não se afrija, nem se afobe,

860 que com o tempo sobe,

87 O tempo mesmo derruba;

88 Tarvez ainda aconteça

89 Que o Brasi de Cima desça

90 E o Brasi de Baxo suba.
91 Sofre o povo privação

92 Mas não pode recramá,

93 Ispondo suas razão

94 Nas coluna do jorná.

95 Mas, tudo na vida passa,

96 Antes que a grande desgraça

97 Deste povo que padece

$98 \mathrm{Se}$ istenda, cresça e redrobe,

99 O Brasi de Baxo sobe

100 E o Brasi de Cima desce.

101 Brasi de Baxo subindo,

102 Vai havê transformação

103 Para os que veve sintindo

104 Abandono e sujeição.

$105 \mathrm{Se}$ acaba a dura sentença

$106 \mathrm{E}$ a liberdade de imprensa

107 Vai sê legá e comum,

108 Em vez deste grande apuro,

109 Todos vão tê no futuro

110 Um Brasi de cada um.

111 Brasi de paz e prazê,

112 De riqueza todo cheio,

113 Mas, que o dono do podê

114 Respeite o dereito aleio.

115 Um grande e rico país

116 Munto ditoso e feliz,

117 Um Brasi dos brasilêro,

118 Um Brasi de cada quá,

119 Um Brasi nacioná

120 Sem monopolo istrangêro. 
Presente no livro Cante lá que eu canto cá, "Brasi de cima, Brasi de baxo" possui doze estrofes de dez versos, isto é, décimas, no caso, do tipo A ( $\mathrm{b}$ b a b c c d e e d), com sete sílabas, metro também conhecido como redondilha maior. Seus versos compostos na variante matuta denunciam os desequilíbrios sociais. Desse modo, Brasil de cima e Brasil de baixo não se referem ao aspecto geográfico Norte e Sul, respectivamente, mas à disparidade de qualidade de vida entre as classes sociais.

Vale destacar que a divisão territorial do país entre Brasil de cima e Brasil de baixo se mostra presente ainda em outro poema, "Inleição direta 1984", encontrado no livro Ispinho e Fulô. Nesses versos, o poeta canta pelo fim do regime militar e destaca as mazelas do país para aqueles que detêm o poder no "Brasi de cima":

Democracia é justiça

Em favor do bem comum

Sem trapaça e sem maliça

Defendendo cada um,

O povo tá sem sossego

Com a fome e o desemprego

Arrochando o brabicacho,

Será que o Brasi de cima

Não tá vendo o triste crima

Que tem no Brasi de baxo?

Seu dotô, seu deputado,

Seu ministro e senado

Repare que o nosso estado

É mesmo um drama de horrô;

Se vossimicê baixasse

E uns dez ano aqui passasse

Ferido na mesma seta,

Fazia assim com nós

Gritando na mesma voz

Queremo inleição direta ${ }^{47}$

Em "Brasi de cima, Brasi de baxo", já na primeira estrofe, pode-se concluir que o sujeito poético é um migrante nordestino - "Faz quage um ano que eu tou / Neste Rio de Janêro; / Eu saí do Cariri” (v.3-5) - dirigindo-se a um interlocutor que lhe é próximo: "Meu compadre Zé Fulô, / Meu amigo e companheiro" (v.1-2). Observa-se ainda um índice temporal que indica quase um ano de exílio desse caboclo.

${ }^{47}$ (PATATIVA DO ASSARÉ. Ispinho e fulô. São Paulo: Hedra, 2005, p. 300). 
O sujeito poético se define como o retirante que escapou da miséria do Norte com esperança de encontrar a sorte no Sul. Desse modo, já na primeira estrofe se estabelece a comparação entre "os Brasis". Todavia, os dois últimos versos dessa estrofe aproximam as duas regiões: "Que a miséria aqui no Su / É esta mesma do Norte" (v.9-10). Tal declaração finda com a ilusão do retirante, pois a mesma miséria nordestina persegue o sertanejo no Sul.

A partir da segunda estrofe, começa-se a enumerar as diferenças entre o Brasil de cima e Brasil de baixo, sendo que o primeiro é para frente: "Aqui no Brasi de Cima,/ Não há dô nem indigença” (v.21-22) -, e o segundo para trás: "Brasi de Baxo, coitado! / É um pobre abandonado" (v.15-16).

Ao longo da leitura desse poema, entende-se que a designação "de cima" e "de baxo" não se refere ao espaço geográfico, pois não há correlação dos termos Norte e Sul. Nessa desorientação espacial, o "Brasi de cima" faz referência ao espaço de privilégios da classe dominante. Com base na caracterização de quem está na condição favorável de poder, "de cima" refere-se ao sentido positivo de progresso, riqueza e opulência, enquanto "de baxo" representa atraso, pobreza e privação.

Para o poeta, o Brasil de baixo, onde se encontra seu povo nordestino, seja no sertão, seja na capital, revela-se unicamente estagnado, um lugar onde o passado pesa sobre o presente, enquanto o Brasil de cima mostra-se como um espaço radicado totalmente no presente e plantando o futuro. A crise político-social nordestina é claramente oriunda de sua estrutura de produção rígida e de seu subdesenvolvimento que sempre acompanha o sertanejo. Logo, a desigualdade social sofrida pelo nordestino é proveniente, segundo o poeta, do tipo de estrutura econômica de sua região e do tipo de relação econômica que esta mantém com o conjunto da economia, o qual oferece ao caboclo apenas a condição de explorado.

O "andar de baixo" do país é marcado pelo despejo em virtude da fome, sendo o sujeito poético um personagem dessa realidade, pois nos primeiros versos este afirma que abandonou sua terra natal imaginando encontrar no Sul uma terra de sorte, isto é, o bem-estar social. Observa-se que esse sujeito possui autoridade para compor os contrapontos e estabelecer a divisão social aqui versus lá. Apesar de sua origem nordestina, seu lugar de fala, no momento do discurso, é a cidade grande do Sul: "Neste Rio de Janêro" (v.4), “[...] aqui no Su" (v.9) e "Aqui no Brasi de cima" (v.21). Logo, ele viu "Eu pude vê neste crima" (v.12) tanto o espaço marginalizado, onde os pobres são tratados "Como se eles fosse bicho / Sem direito de vivê" (v. 69-70), quanto o polo dinâmico da economia, marcado pela transformação e pela indústria "Fala de transformação, / Industra, matéra prima, / Descobertas e invenção" (v.52-54). 
Comumente em Patativa do Assaré, o Sul é o espaço-outro a quem o retirante se dirige em diáspora, espaço imagético-discursivo marcado pelo capitalismo e pela modernidade em contraponto ao sistema feudal e arcaico do Norte. Todavia, nesse poema, o sertanejo já partiu do lugar primitivo e agora fala no espaço civilizado, portanto, não se trata mais de suposições quanto a uma terra prometida. O sujeito poético encontra-se na cultura urbano-industrial e dá indícios de que ainda conhece a miséria, tendo em vista os dois últimos versos da primeira estrofe, como já mencionado.

Apesar de residir no Sul, o sujeito lírico ainda se reconhece como nordestino, tendo em vista a variante matuta. Observa-se também, na nona estrofe, uma troca de interlocutor; o canto, inicialmente dirigido a seu companheiro Zé Fulô, passa a chamar todo povo oprimido: "Meu Brasi de baxo, amigo" (v.81). Em sua poética, o Nordeste e, consequentemente, o sertanejo sempre se encontram na condição de subalternos na rede de poderes, subjugados por aqueles que têm o domínio do espaço nacional. Dessa forma, o sertanejo, ainda que esteja longe da terra natal, sempre será fadado à miséria nos centros urbanos. Independente dos surtos de crescimento do país, o sertão nordestino e o pobre matuto jamais conheceram o desenvolvimento ou uma integração mais estreita com polo dinâmico da economia. O Brasil de baixo representa o capital e a mão de obra para o desenvolvimento do Brasil de cima. $\mathrm{O}$ sertanejo que de lá parte serve para atender à demanda do setor industrial e pressionar os salários para baixo, continuando explorado nas grandes capitais.

A atividade primária no Brasil de baixo é feita de tal forma que não se cria um mercado interno, devido aos baixos salários vigentes na região e à grande parcela da população que vive em nível de subsistência. A estrutura agrária funciona como um bloqueio à industrialização regional, pois não gera um mercado para o escoamento de seus produtos. Assim, em prejuízo próprio, dentro das regras do jogo do processo de desenvolvimento, esse Brasil de baixo fornece o trabalho braçal, exaustivamente explorado, para o Brasil de cima.

Ao fim, o sujeito poético do citado poema tem esperança que haja uma inversão de papeis, ou seja, que o Brasil de cima desça e o Brasil de cima suba: “Antes que a grande desgraça / Deste povo que padece / Se istenda, cresça e redrobe, / O Brasi de Baxo sobe / E o Brasi de Cima desce” (v. 96-100). As últimas estrofes representam a esperança de findar esse país dividido e construir um "Brasi dos brasilêro": "Um grande e rico país / Munto ditoso e feliz, / Um Brasi dos brasilêro, / Um Brasi de cada quá, / Um Brasi nacioná” (v. 115-119).

Apesar de o poema retratar a desigualdade de classe e não apenas o desequilíbrio regional, a contraposição entre Norte e Sul, sertão e capital, revela-se uma temática recorrente na obra patativana. No poema “Assaré”, por exemplo, presente em Inspiração nordestina e 
Ispinho e fulô, o poeta retrata sua "terra do coração" em oposição à "cidade rica". Novamente, a esperança de um novo destino é cantada:

Conheço cidade rica

Que quem repara, tá vendo

Que quanto mais véia fica,

Mais nova tá parecendo.

Mas tu, Assaré querido,

Véio, cacundo, incuído,

Com os óio fito pro chão,

Não tem conforto nem nome!

Só é lembrado dos home

Quando é tempo de inleição.

Mas tu, meu torrão que chora,

Vai suportando o desgosto

Inté que uma nova orora

Venha briá no teu rosto.

Pode sê, minha cidade,

Que um dia a felicidade

Te alevante do paú

E a Divina Providênça,

Com o seu podê e cremença

Mande um oxilo p'ra tu ${ }^{48^{3}}$.

Na obra poética patativana, o interlocutor, muitas vezes, é o doutor da capital que não conhece a realidade dura da classe camponesa. Por esse motivo, o poeta canta, não apenas para o seu povo nordestino, mas também para o Brasil de cima tomar conhecimento do padecer do Brasil de Baixo:

Seu dotô, só me parece

Que o sinhô não me conhece,

Nunca sôbe quem sou eu,

Nunca viu minha paioça,

Minha muié, minha roça,

E os fio que Deus me deu.

Se não sabe, escute agora,

Que eu vô contá minha históra,

Tenha a bondade de uvi:

Eu sou da crasse matuta,

Da crasse que não desfruta

Das riqueza do Brasi $^{49}$.

48 (PATATIVA DO ASSARÉ. Inspiração nordestina. São Paulo: Hedra, 2006a, p. 49).

49 (PATATIVA DO ASSARÉ. Cante lá que eu canto cá. Petrópolis: Vozes, 2014, p. 114). 
Em resumo, o poema "Brasi de cima, Brasi de baxo" é composto por contrapontos entre as duas classes sociais do país. O Brasil de cima, da riqueza e do progresso, é descrito como o espaço-outro contra o qual se constitui o Brasil de baixo, da "crasse marginá". Patativa do Assaré, como poeta da justiça social, apresenta, nesses versos, a vida de um país marcado por fronteiras de contradições. Dessa forma, a existência de dois Brasis e de duas realidades absurdamente opostas é a grande denúncia desse poema, tendo em vista que o poeta matuto evidencia, sem rodeios, como uma região ("Brasi de cima") desfruta de bemestar social e desenvolvimento, enquanto outra ("Brasi de baxo") vive na mais absoluta miséria e abandono, escancarando a disparidade social já tão expressiva. 


\subsection{O INFERNO, O PURGATÓRIO E O PARAÍSO}

01 Pela estrada da vida nós seguimos, 02 Cada qual procurando melhorar, 03 Tudo aquilo, que vemos e que ouvimos, 04 Desejamos, na mente, interpretar, 05 Pois nós todos na terra possuímos $06 \mathrm{O}$ sagrado direito de pensar, 07 Neste mundo de Deus, olho e diviso 08 O Purgatório, o Inferno e o Paraíso.

09 Este Inferno, que temos bem visível 10 E repleto de cenas de tortura, 11 Onde nota-se o drama triste horrível 12 De lamentos e gritos de loucura $13 \mathrm{E}$ onde muitos estão no mesmo nível 14 De indigência, desgraça e desventura, 15 É onde vive sofrendo a classe pobre 16 Sem conforto, sem pão, sem lar, sem cobre.

17 É o abismo do povo sofredor, 18 Onde nunca tem certo o dormitório 19 É sujeito e explorado com rigor 20 Pela feia trapaça do finório 21 É o inferno, em plano inferior, 22 Mas acima é que fica o Purgatório, 23 Que apresenta também sua comédia 24 E é ali onde vive a classe média.
25 Este ponto também tem padecer, 26 Porém seus habitantes é preciso 27 Simularem semblantes de prazer, 28 Transformando a desdita num sorriso. 29 E agora, meu leitor, nós vamos ver, 30 Mais além, o bonito Paraíso, 31Que progride, floresce e frutifica, 32 Onde vive gozando a classe rica.

33 Este é o Éden dos donos do poder, 34 Onde reina a coroa da potência. 35 O Purgatório ali tem que render 36 Homenagem, Triunfo e Obediência. 37 Vai o Inferno também oferecer 38 Seu imposto tirado da indigência, 39 Pois, no mastro tremula, a todo instante, 40 A bandeira da classe dominante.

41 É o Inferno o teatro do agregado $42 \mathrm{E}$ de todos que vivem na pobreza, 43 Do faminto, do cego e do aleijado, 44 Que não acham abrigo nem defesa 45 E é também causador do triste fado 46 Da donzela repleta de beleza 47 Que, devido à cruel necessidade, 48 Vende as flores de sua virgindade. 
49 Que tristeza, que mágoa, que desgosto

50 Sente a pobre mendiga pela rua!

$51 \mathrm{O}$ retrato da dor no próprio rosto,

52 Como é dura e cruel a sorte sua!

53 Com o corpo mirrado e mal composto,

54 A coitada chorosa continua

55 A pedir, pelas praças da cidade:

56 "Uma esmola, senhor, por piedade!"

57 Para que outro estado mais precário

58 Do que a vida cansada do roceiro?

59 Sem gozar do direito do salário,

60 Trabalhando na roça o dia inteiro,

61 Nunca pode ganhar o necessário,

62 Vive sempre sem roupa e sem dinheiro,

$63 \mathrm{E}$, se o inverno não vem molhar o chão,

64 Vai expulso da roça do patrão.

65 Como é triste viver sem possuir

66 Uma faixa de terra para morar

67 E um casebre, no qual possa dormir

68 E dizer satisfeito: “este é meu lar".

69 Ninguém pode, por certo, resistir

70 Tal desgraça na vida sem chorar.

71 Se é que existe inferno no outro mundo

72 Com certeza, o de lá é o segundo!

73 Veja bem, meu leitor, que quadro triste,

74 Este inferno que temos nesta vida,

$75 \mathrm{O}$ sofrimento atroz dele consiste

$76 \mathrm{Em}$ viver sem apoio e sem guarida.

77 Minha lira sensível não resiste

78 Descrever tanta coisa dolorida

79 Com as rimas do mesmo repertório,

80 Quero um pouco falar do Purgatório
81 Purgatório da falsa hipocrisia,

82 Onde vemos um rosto prazenteiro

83 Ocultando uma dor que o excrucia

84 E onde vemos também um cavalheiro

85 Usar terno de linda fantasia,

86 Com o bolso vazio de dinheiro:

87 Pra poder trajar bem, até se obriga

88 Dar, com jeito, uma prega na barriga.

89 Purgatório infeliz do desgraçado,

90 Que trabalha e faz tudo o que é preciso

91 No comércio, lutando com cuidado,

92 Com desejo de entrar no Paraíso,

93 Porém quando termina derrotado,

94 Fracassado, com grande prejuízo,

95 Desespera, enlouquece, perde a bola

96 E no ouvido dispara uma pistola

97 Ali vemos um gesto alegre e lindo

98 Disfarçando uma dor, uma aflição,

99 Afirmando gozar prazer infindo

100 De esperança, de sonho e de ilusão.

101 Mas, enquanto esses lábios vão sorrindo,

102 Vai chorando, no peito, o coração.

103 É um mundo repleto de amarguras,

104 Com bastante aparência de venturas.

105 Veja agora leitor que diferença

106 Encontramos no lindo Paraíso:

107 O habitante não fala de sentença

108 Tudo é paz, alegria, graça e riso.

109 Tem remédio e conforto, na doença

$110 \mathrm{E}$, se a morte lhe surge, de improviso,

111 Quando morre inda deixa por memória

112 Uma lousa, contando a sua glória. 
113 Neste reino, que cresce e que vigora,

114 Vive a classe feliz e respeitada,

115 Tem tudo o que quer, a toda hora,

116 Pois do belo e do bom não falta nada,

117 Tem estrela brilhante e linda aurora,

118 Borboletas azuis, contos de fada

$119 \mathrm{E}$, se quer gozar mais a vida sua,

120 Vai uns dias passar dentro da lua.

121 O Paraíso e o ponto culminante

122 De riqueza, grandeza e majestade,

123 Ali o homem desfruta ouro e brilhante,

124 Vive em plena harmonia e liberdade,

125 Tem sossego, conforto e tem amante,

126 Tudo quanto há de bom tem à vontade

$127 \mathrm{E}$ a mulher, que possui corpo de elástico,

128 Para não ficar velha, vai ao plástico.
129 Já mostrei, meu leitor, com realeza,

130 Pobres, médios e ricos potentados,

$131 \mathrm{Na}$ linguagem sem arte e sem riqueza.

132 Não são versos com ouro burilados,

133 São singelos, são simples, sem beleza,

134 Mas, nos mesmos eu deixo retratados,

135 Com certeza, verdade e muito siso,

136 O Purgatório, o Inferno e o Paraíso.

Apesar do título, não há qualquer indício de que Patativa do Assaré tenha se inspirado no poema épico de Dante Alighieri, A Divina Comédia, para compor seu clássico poema "O Inferno, o Purgatório e o Paraíso". Presente no livro Cante lá que eu canto cá, tais versos seguem, na verdade, os moldes camonianos de Os Lusíadas, isto é, apresentam versos em oitava decassílabas (oito versos de dez sílabas métricas), sujeitas ao esquema rímico $a b a b a$ $b c c$.

Sabe-se que o poeta lusitano estava entre as leituras de Patativa, como se pode confirmar pelo poema "Luís de Camões", no qual o sertanejo busca render ruma homenagem ao grande "bardo português":

Eu sou poeta selvagem,

Não recebi instruções,

É rude a minha linguagem

E fracas as expressões

Para render homenagem

Ao grande poeta Camões,

Que com o seu pensamento

Deu à Pátria um monumento.

E eu que das coisas terrestres 


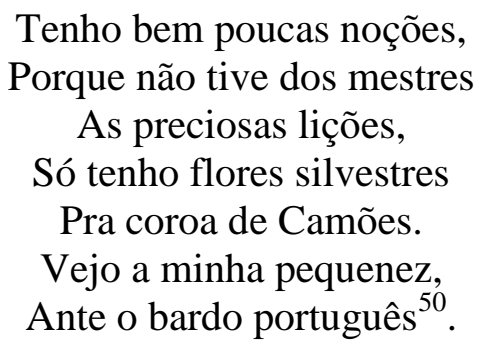

A leitura de Camões inspirou o poeta matuto a compor o poema aqui analisado, "O Inferno, o Purgatório e o Paraíso", como declarou em entrevista ao pesquisador e colega Gilmar de Carvalho:

\begin{abstract}
Ali é uma história muito bonita, mas pra quem não estudou muito, não é tão compreensível. Mas eu li todo e aprendi aquela forma de versificação dos "Lusíadas". É tanto que aquele meu poema "O Purgatório, o Inferno e o Paraíso", a versificação é aquela mesma: "das armas e barões assinalados, / que da ocidental praia lusitana, / por mares dantes nunca navegados [...]” (PATATIVA DO ASSARÉ apud CARVALHO, 2002a, p. 24).
\end{abstract}

Seguindo o modelo da poesia clássica, o poeta optou pela norma padrão da língua portuguesa, o que evidencia a facilidade com que transitava entre a língua matuta e a culta. Patativa do Assaré sempre se preocupou em mostrar também sua habilidade com a poesia clássica, no intuito de findar com a velha imagem de inferioridade do poeta popular. Assim, valia-se de cada linguagem conforme os objetivos que tinha em mente e o público que desejava atingir.

Como já mencionado, o poema, na primeira edição de Cante lá que eu canto cá (1978), apresentava um erro grave que alterava totalmente o sentido do verso dez. No lugar do vocábulo "tortura": "Este Inferno, que temos bem visível / E repleto de cenas de tortura" (v.910), lia-se "ternura". Felizmente, as edições seguintes corrigiram esta falha.

"O Inferno, o Purgatório e o Paraíso" revela o poder de ressignificação da poesia patativana, pois o poeta reinterpreta a crença cristã dos três destinos possíveis do homem após a morte e compõe seus versos pautando-se nas três classes sociais: "pobres, médios e ricos" (v. 130). Assim, ao longo do poema tem-se o retrato do espaço destinado a cada classe: o inferno para o pobre, o purgatório para a classe média e o paraíso para os ricos. Diferente da poesia matuta que se apoia na oralidade, aqui o interlocutor é o leitor desses versos: "Veja bem, meu leitor, que quadro triste" (v. 73).

${ }^{50}$ (PATATIVA DO ASSARÉ. Cante lá que eu canto cá. Petrópolis: Vozes, 2014, p. 251). 
O Inferno, grafado com maiúsculas, é descrito como o espaço da indigência, desgraça e desventura. Como um abismo do povo sofredor, o Inferno "É onde vive sofrendo a classe pobre / Sem conforto, sem pão, sem lar, sem cobre" (v.15-16). Ali se encontra o agregado, o faminto, o cego, o aleijado, a mendiga, enfim, todos aqueles que vivem sem apoio e sem guarida.

Observa-se que no Inferno patativano recolhem-se os mesmos personagens que ocupam toda a obra do poeta. Novamente há o pobre roceiro que vive nas terras do patrão: "Como é triste viver sem possuir / Uma faixa de terra para morar / E um casebre, no qual possa dormir / E dizer satisfeito: 'este é meu lar”" (v. 65-68), como em “O agregado":

Quem véve no luxo, somente gozando,

Dinhêro gastando sem mágoa e sem dô, Não sabe, nem pensa e tombém não conhece

O quanto padece quem mora a favô ${ }^{51}$.

Há ainda a mendiga, "Que tristeza, que mágoa, que desgosto / Sente a pobre mendiga pela rua! / O retrato da dor no próprio rosto, / Como é dura e cruel a sorte sua!” (v. 49-52), também presente em "A menina mendiga" e "Menino de rua", como seguem respectivamente:

De pés descalços sobre o frio chão,

Roto o vestido, em desalinho a trança,

De porta em porta a mendigar o pão,

Vai pela rua uma infeliz criança ${ }^{52}$.

Teus olhos demonstram a dor, a tristeza,

Miséria, pobreza

E cruéis privações

E enquanto estas dores tu vives penando,

Vão ricos roubando

Milhões e milhões ${ }^{53}$.

O Purgatório, por sua vez, “[...] onde vive a classe média” (v. 24), também tem seu padecer, porém ali se simula uma falsa felicidade, enquanto se oculta a dor: "É um mundo repleto de amarguras, / Com bastante aparência de venturas" (v. 103-104). O objetivo maior dessa classe média é trabalhar para entrar no Paraíso, assim vive o "cavalheiro" trajando um belo terno, porém com o "bolso vazio de dinheiro".

\footnotetext{
${ }^{51}$ (PATATIVA DO ASSARÉ. Cante lá que eu canto cá. Petrópolis: Vozes, 2014, p. 339).

52 (PATATIVA DO ASSARÉ. Inspiração nordestina. São Paulo: Hedra, 2006a, p. 197).

${ }^{53}$ (PATATIVA DO ASSARÉ. Aqui tem coisa. São Paulo: Hedra, 2012a, p. 11).
} 
Em "Inleição direta 1984", presente no livro Ispinho e Fulô, o poeta matuto aproxima as dores do pobre e da classe média, afirmando que estão todos "desmantelados" e, principalmente, findando com a falsa ilusão de que a classe média enriquecerá ao ponto de alcançar o Paraíso:

Isto qu eu digo é exato

É uma verdade certa

Pois só o que carça o sapato

Sabe onde é que o mesmo aperta,

Nosso país invejado

Tá todo desmantelado

O que observa descobre

E com certeza tá vendo

A crasse pobre morrendo

E a média ficando pobre ${ }^{54}$.

O Paraíso, por sua vez, lugar dos donos do poder - "Que progride, floresce e frutifica, / Onde vive gozando a classe rica" (v. 31-32) -, é marcado pela riqueza e pela grandeza. Ali todos vivem em plena harmonia e liberdade: "Tudo é paz, alegria, graça e riso". Podem-se imaginar as figuras que ocupam o espaço do Paraíso, tendo como base os personagens recorrentes na poética patativana: o coronel, o fazendeiro, o patrão do operário, o senhor doutor da capital, todos já comentados nessa dissertação.

Como em outros poemas, em “O Inferno, o Purgatório e o Paraíso”, Patativa do Assaré também estabelece a relação de exploração entre as três classes. Comumente, o poeta matuto revela a exploração que sofre o agregado com o fazendeiro, o operário com o patrão, o povo com os governantes. No Paraíso encontra-se a "bandeira da classe dominante" a quem todos, Inferno e Purgatório, devem obediência e, principalmente, impostos (v. 33-40):

Este é o Éden dos donos do poder,

Onde reina a coroa da potência.

O Purgatório ali tem que render

Homenagem, Triunfo e Obediência.

Vai o Inferno também oferecer

Seu imposto tirado da indigência,

Pois, no mastro tremula, a todo instante,

A bandeira da classe dominante.

${ }^{54}$ (PATATIVA DO ASSARÉ. Ispinho e fulô. São Paulo: Hedra, 2005, p. 300). 
Outra característica marcante da obra patativana que se repete no poema é o contraste, constante nos dualismos entre caboclo e doutor da capital, sertão e cidade, poesia erudita e poesia matuta. No entanto, em "O Inferno, o Purgatório e o Paraíso" não há apenas dois princípios antagônicos, como de costume, mas três em referência às três classes sociais: a baixa, a média e a alta. Apesar de certa aproximação comparativa entre o pobre e a classe média, já que ambos não compartilham da abundância da classe alta, grupo a quem pertence o Paraíso, o Purgatório (classe média) ainda se encontra acima do Inferno (pobre).

Nota-se, nos versos simples do poema, o retrato fiel dos espaços destinados às três classes: "Não são versos com ouro burilados, / São singelos, são simples, sem beleza, / Mas, nos mesmos eu deixo retratados, / Com certeza, verdade e muito siso, / O Purgatório, o Inferno e o Paraíso" (v. 132-136). Como em muitos outros poemas de Patativa do Assaré, para além da importância artística e criativa, constata-se uma aguda consciência crítica diante da realidade inóspita de nossa sociedade desigual. 


\subsection{A LIÇÃO DO PINTO}

1 Vamos meu irmão,

2 A grande lição

3 Vamos aprender,

4 É belo o instinto

5 Do pequeno pinto

6 Antes de nascer.

$7 \mathrm{O}$ pinto dentro do ovo

8 Está ensinando ao povo

9 Que é preciso trabalhar,

10 Bate o bico, bate o bico

11 Bate o bico tico tico

12 Pra poder se libertar.

13 Vamos minha gente,

14 Vamos para frente

15 Arrastando a cruz

16 Atrás da verdade

17 Da fraternidade

18 Que pregou Jesus.
19 O pinto prisioneiro

20 Pra sair do cativeiro

21 Vive bastante a lutar,

22 Bate o bico, bate o bico,

23 Bate o bico tico tico

24 Pra poder se libertar.

25 Se direitos temos,

26 Todos nós queremos,

27 Liberdade e paz,

28 No direito humano

29 Não existe engano,

30 Todos são iguais.

$31 \mathrm{O}$ pinto dentro do ovo

32 Aspirando um mundo novo

33 Não deixa de beliscar

34 Bate o bico tico tico

35 Bate o bico, bate o bico

36 Pra poder se libertar.

Os versos de "Lição do pinto" encontram-se nos livros Ispinho e fulô (2005, p. 165) e Aqui tem coisa (2012, p. 127). Vale destacar que os dois livros apresentam registros diferentes do poema, enquanto o primeiro (como verificado acima) mostra-se na norma culta ao respeitar as grafias e as vírgulas, além de iniciar todos os versos com maiúsculas; em Aqui tem coisa, o registro é informal, como se pode observar nos léxicos "precizo" (v. 9), "atráz" (v. 16), "prezioneiro" (v.19), "veve” (v. 21), além dos versos se iniciarem em letras minúsculas. Apesar desse impasse, pode-se considerar o poema na norma culta, pois as edições de Ispinho e fulô apresentam graves problemas de transcrição em diversos poemas.

Os versos de "Lição do pinto" apresentam-se metafóricos e didáticos ao comparar a luta do pinto para se livrar de sua casca, vista como um cativeiro, e a necessidade de 
mobilização do povo para conquistar a liberdade e a justiça. Como já abordado no capítulo anterior, o poema foi composto por Patativa do Assaré em sua participação na luta pela anistia aos presos e exilados políticos, em 1979. Vale destacar que a campanha pela anistia, organizada por intelectuais, artistas, jornalistas, sindicatos e estudantes, ganhou força no final dos anos 70 e foi o primeiro movimento nacional unificado e progressista contra a ditadura militar. A repressão que vivia o país, frente às torturas e aos assassinatos, despertou a população para a luta. Manifestações começaram a ocupar as ruas, tornando esse movimento um grande responsável pela ampliação das conquistas democráticas do povo brasileiro.

Como defensor da anistia aos presos políticos, o poeta subiu aos palanques com as principais lideranças oposicionistas brasileiras e se apresentou, na Praça do Ferreira, juntamente com Darcy Ribeiro. A respeito da composição do poema, que foi motivada por um convite, Patativa do Assaré fez o seguinte comentário:

[...] passei a noite quase acordado, procurando o que era que eu ia dizer. Aí me veio a lembrança que o pinto sai do ovo porque trabalha e não porque a natureza faça aquele ovo se abrir para que o pinto saia de dentro. Não, não é assim. Ele belisca o ovo até poder sair de dentro. Aí eu me apoiei nesse negócio e fiz o poema, viu (FEITOSA, 2003, p. 113).

O poema constitui-se em sextilhas (estrofes de seis versos), alternando o metro (medida do verso), ora redondilha menor (cinco sílabas métricas), ora redondilha maior (sete sílabas métricas). Sobre a estrofação e os esquemas rímicos na obra patativana, cabe mencionar o trabalho de Cláudio Andrade, em Aspectos e impasses na poesia de Patativa do Assaré (2008). O pesquisador apresenta um completo estudo acerca das formas poéticas do sertanejo. Em relação à sextilha, Andrade explica que é a estrofe predominante no cordel: “A sextilha está para a literatura de cordel assim como a décima está para a obra de Patativa do Assaré, ocupando o primeiríssimo lugar” (p. 86). Vale destacar que as sextilhas sem rimas não constam em sua poética.

Como já exposto, as sextilhas empregadas por Patativa do Assaré são de três tipos diferentes. A estrofe de seis versos mais tradicional, também chamada de sextilha antiga, usada nas cantigas populares e nos folhetos de cordel, caracteriza-se por possuir rima única nos versos pares, a qual varia de estrofe em estrofe. Trata-se de um esquema de rimas que requer o menor esforço, sendo predominante na obra de Leandro Gomes de Barros, considerado o primeiro grande poeta da nossa literatura de cordel. Dos cinco poemas de Patativa do Assaré compostos neste tipo de sextilha, quatro foram publicados sob a forma de folhetos. Logo, o poeta afasta-se do modelo cordel, tendo em vista que a maioria das estrofes 
de seis versos utilizada por ele refere-se a dois tipos jamais empregados nos folhetos, a sextilha moderna e a composta.

A sextilha moderna, modalidade de estrofe de seis versos mais utilizada por Patativa do Assaré (cerca de 70\% dos poemas), apresenta todos os seis versos rimando aos pares, assim distribuídos: a a $b$ c $c$ b. O emprego desta, vale saber, largamente praticada por poetas da lírica moderna, notadamente os românticos, em detrimento da utilização da sextilha antiga ou sextilha cordel, revela-se como um claro indício de variedade da obra de Patativa do Assaré. Com este tipo de estrofe e seu esquema de rimas, o caboclo compôs tanto poemas na língua matuta como na língua culta.

A sextilha composta, por sua vez, do mesmo tipo que a anterior ( $a$ a $b$ c $c b$ ), pode também apresentar versos de diferentes medidas: em versos de dez ( $a$ a e $c c$ ) e de seis sílabas $(b$ e $b$ ). A sextilha composta apresenta sempre quatro versos na medida maior e dois versos na medida menor. Entretanto, em Patativa do Assaré, são apenas dois versos na medida maior e quatro na medida menor (ANDRADE, 2008, p. 95).

Cláudio Andrade afirma que não encontrou a sextilha composta da obra patativana (dois versos na medida maior e quatro na menor) nos poetas românticos que constam nas leituras do sertanejo, como Castro Alves e Casimiro de Abreu, nem nas obras dos cordelistas que poderiam ter fornecido o modelo a Patativa do Assaré, como Zé da Luz.

O pesquisador apresenta uma hipótese sobre o elemento unificador que caracteriza todos os poemas escritos em sextilhas compostas por Patativa do Assaré. Segundo Andrade, são versos que se ocupam exclusivamente de questões e problemas sociais:

\footnotetext{
Eles, sem exceção, são poemas de denúncia social, falam de situações sofridas e dolorosas enfrentadas pelos personagens. Esta forma jamais foi veículo de temas "felizes" se assim posso me expressar. Coisa diferente verifica-se com os poemas escritos em quadras com seis rimas [...] Embora estes possam figurar o fazem de modo discreto e secundário, havendo um halo misto de leveza, celebração e consciência crítica, combinação peculiar que os diferencia dos poemas em sextilha composta $(2008$, p. 100).
}

Após tais observações, pode-se afirmar que "Lição do pinto" não se encaixa em nenhum modelo determinado por Andrade. Apesar do estudioso definir o poema como sextilha moderna, no anexo de sua dissertação, a metrificação deste difere das demais poesias desse modelo. Enquanto "Ao poeta do sertão", "Seu Dotô me conhece?” e "O Caçador", por exemplo, inseridos na lista das sextilhas modernas, apresentam versos com sete sílabas métricas (heptassílabos), assim como todos os outros poemas encontrados nesse grupo, "Lição do pinto" alterna entre sete e cinco sílabas, ou seja, entre redondilha maior e menor. 
Do mesmo modo, o poema não pode ser considerado sextilha composta, pois, apesar desse modelo ser assim nomeado por apresentar versos de duas medidas diferentes, suas poesias apresentam sempre dois versos na medida maior e quatro na medida menor dentro de uma mesma estrofe. "Lição do pinto", por sua vez, ora traz toda uma estrofe em redondilha maior, ora menor. Com base nas nossas leituras, não encontramos nenhum outro poema com a mesma singularidade. Portanto, trata-se de um tipo único em toda a obra patativana.

Todavia, pode- afirmar sem receio que "Lição do pinto" apresenta um forte caráter social, já que seu sujeito poético busca unir os trabalhadores em uma luta por igualdade. Assim, os versos "Bate o bico tico tico / Bate o bico, bate o bico / Pra poder se libertar" (v. 10, 11 e 12) funcionam como uma espécie de refrão desse canto engajado.

Observa-se que as estrofes com redondilha menor apresentam-se claramente como diálogo com o interlocutor, no caso, o "irmão" e "minha gente", o que revela uma aproximação entre o sujeito poético e aquele a quem se dirige, além de uma ideia de pertencimento ao grupo. Nessas estrofes, sempre dois versos valem-se da primeira pessoa do plural: "Vamos meu irmão, [...] /Vamos aprender" (v. 1 e 3), "Vamos minha gente, / Vamos para frente" (v. 13 e 14), "Se direitos temos, / Todos nós queremos" (v. 25 e 26), o que fortalece a ideia de união deste e seus pares. Ainda nessas estrofes, o poeta sempre chama seu interlocutor para aprender uma lição, lutar ou mostrar seus direitos.

As estrofes em redondilha maior, por sua vez, trazem a história do pinto de forma metafórica e didática, como paralelo em que o povo poderia se espelhar. Assim como o pinto prisioneiro apresenta um instinto natural de se libertar de sua casca, os homens precisam lutar para conquistar a liberdade e a paz. O pinto que fica batendo em sua casca para sair de seu cativeiro deve ser o exemplo para o povo que aspira um mundo novo, marcado pela igualdade e pela justiça.

Além do pinto, outro paradigma é Jesus Cristo, que, arrastando a cruz, pregou a verdade e a fraternidade. A referência divina é uma constante na obra patativana e na cultura popular nordestina como um todo. O poeta concebe-se como um socialista cristão, logo, a presença de Cristo nesse poema não é casual. Além disso, a questão da fé e da fraternidade, as quais são constitutivas da religião cristã, está em consonância com o sentimento de luta que defende o sujeito lírico.

Assim como o pinto e Jesus Cristo, o povo deve aspirar a um mundo novo e lutar por este, pois "no direito humano / [...] / todos são iguais" (v. 28 e 30). Tal atitude do sujeito poético evidencia o papel do poeta social enquanto porta-voz do povo, pois, como já abordado, Patativa do Assaré se vê na missão de esclarecer a verdade e defender a justiça. 
Como poeta popular, Patativa do Assaré cantou o sofrimento de seu povo, pois tinha consciência das possibilidades de mudança e do impacto de sua voz. A realidade do país sempre foi a principal fonte de inspiração do poeta. A escolha de uma poesia metafórica e didática como "Lição do pinto" tem como intuito tornar mais compreensível a todos o teor de luta e resistência do povo reprimido. O poeta se vale de uma linguagem simples e de referências populares, como o pinto e a religião, para contextualizar seu projeto de educar sua gente.

Patativa do Assaré compôs ainda outras poesias no modelo da fábula no intuito de tornar mais didático certo esclarecimento ao seu povo, entre eles "O peixe", "O boi Zebu e as formigas" e "Teia de aranha".

O soneto "O peixe", presente em Inspiração nordestina e Cante lá que eu canto cá, vale-se da norma padrão, bem diferente de "Lição do pinto", e estabelece um paralelo entre o animal aquático e o camponês tendo como base a isca e a campanha eleitoral. Do mesmo modo que o peixe frente à isca, o camponês se mostra inocente perante o "fatal destino" do pleito. Logo, o anzol do pescador ladino representa o Estado, o qual se revela ludibrioso para o povo, pois, após a festa do pleito, apenas instaura "imposto e mais imposto":

Tendo por berço o lago cristalino, Folga o peixe, a nadar todo inocente, Medo ou receio do porvir não sente, Pois vive incauto do fatal destino.

Se na ponta de um fio longo e fino A isca avista, ferra-a inconsciente, Ficando o pobre peixe de repente, Preso ao anzol do pescador ladino.

O camponês, também, do nosso Estado, Ante a campanha eleitoral, coitado! Daquele peixe tem a mesma sorte.

Antes do pleito, festa, riso e gosto, Depois do pleito, imposto e mais imposto.

Pobre matuto do sertão do Norte! ${ }^{55}$

Em décimas, os versos heptassílabos de "O boi Zebu e as formigas", por sua vez, presentes em Ispinho e fulô, constroem-se como metáfora sobre o poder de união do povo. O

55 (PATATIVA DO ASSARÉ. Inspiração nordestina. São Paulo: Hedra, 2006a, p. 202). 
boi, representado como um "grande animá" "valentão" e "ignorante", firma as quatro patas em cima do formigueiro, o qual se revela "um grande inzempro" ao viver em "perfeita união" e trabalhar pacientemente. "Zangadas" com aquela chegada, as formigas se reúnem e sobem em Zebu, que, mesmo com seus fortes coices, não consegue vencer frente o grande número daquelas:

$$
[\ldots]
$$

Com a feição de guerrêra

Uma formiga animada

Gritou para as companhêra:

Vamo minhas camarada

Acaba com os capricho

Deste ignorante bicho

Com a nossa força comum

Defendendo o formiguêro

Nos somos muitos miêro

E este zebu é só um.

$$
[\ldots]
$$

Com o lombo todo ardendo

Daquele grande aperreio zebu saiu correndo

Fungando e berrando feio

$\mathrm{E}$ as formiga inocente

Mostraro pra toda gente Esta lição de morá

Contra a farta de respeito

Cada um tem seu direito

Até nas leis da natura.

As formiga a defendê

Sua casa, o formiguêro,

Botando o boi pra corrê

Da sombra do juazêro, Mostraro nessa lição

Quanto pode a união;

Neste meu poema novo

O boi zebu qué dizê

Que é os mandão do podê,

$\mathrm{E}$ as formiga é o povo ${ }^{56}$

Outra metáfora social está presente em "Teia de aranha”, poema escrito em sextilha moderna ( $a r a b c c c c$ ), encontrado em Balceiro e em Melhores poemas. Nesses versos em redondilha maior, o sujeito poético aborda, de forma didática e popular, a teia de ignorância,

${ }^{56}$ (PATATIVA DO ASSARÉ. Ispinho e fulô. São Paulo: Hedra, 2005, p. 42). 
na qual os analfabetos do país, negados os seus direitos, veem-se subordinados. A aranha é descrita como "tramista" e "sabida", além de viver "da desgraça alheia", sendo para o poeta a representação da política brasileira. Já o besouro, "pequeno animalzinho", "livre" e "inocente", logo, involuntariamente, vê-se preso na "falsa rede da aranha":

Parado na teia o inseto Passa uns momentos inquieto

Mas não pode se livrar,

Preso naquele tecido

Sente que está proibido

Seu direito de voar.

Os nossos analfabetos São como aqueles insetos, Com a mesma circunstância

Seus direitos são negados

E vivem subordinados

$\mathrm{Na}$ teia da ignorância ${ }^{57}$

Poeta comprometido com seu tempo histórico, Patativa do Assaré compôs "Lição do pinto”, a convite de Darcy Ribeiro, para o Movimento pela Anistia, traduzindo o sentimento da sociedade da época. Tratava-se de um canto no qual se ordenava e suplicava a luta pela justiça perante os abusos cometidos pelo regime militar. Hoje, apesar de vivermos outra conjuntura histórica, observa-se que o poema se mostra ainda atual, tendo em vista que as demandas sociais de Patativa não foram alcançadas, como a igualdade de direitos. Logo, para o poeta, a mobilização popular, pela real democracia, ainda seria necessária.

57 (PATATIVA DO ASSARÉ. Melhores poemas: Patativa do Assaré. São Paulo: Global, 2006b, p. 195). 


\subsection{O AGREGADO E O OPERÁRIO}

1 Sou matuto do Nordeste,

2 Criado dentro da mata.

3 Caboclo cabra da peste,

4 Poeta cabeça-chata.

5 Por ser poeta roceiro,

6 Eu sempre fui companheiro

7 Da dor, dia mágoa e do pranto.

8 Por isso, por minha vez,

9 Vou falar para vocês

10 O que é que eu sou e o que eu canto:

11 Sou poeta agricultor,

12 Do interior do Ceará.

13 A desdita, o pranto e a dor,

14 Canto aqui e canto acolá.

15 Sou amigo do operário

16 Que ganha um pobre salário,

$17 \mathrm{E}$ do mendigo indigente.

18 E canto com emoção

19 O meu querido sertão

$20 \mathrm{E}$ a vida de sua gente.

21 Procurando resolver

22 Um espinhoso problema,

$23 \mathrm{Eu}$ procuro defender,

24 No meu modesto poema,

25 Que a santa verdade encerra,

26 Os camponeses sem terra

27 Que os céus desse Brasil cobre,

$28 \mathrm{E}$ as famílias da cidade

29 Que sofrem necessidade,

30 Morando no bairro pobre.
31 Vão no mesmo itinerário,

32 Sofrendo a mesma opressão.

33 Na cidade, o operário;

34 E o camponês, no sertão.

35 Embora, um do outro ausente,

36 O que um sente, o outro sente.

37 Se queimam na mesma brasa

$38 \mathrm{E}$ vivem na mesma guerra:

39 Os agregados, sem terra;

40 E os operários, sem casa.

41 Operário da cidade,

42 Se você sofre bastante,

43 A mesma necessidade

44 Sofre o seu irmão distante.

45 Sem direito de carteira,

46 Levando vida grosseira,

$47 \mathrm{Seu}$ fracasso continua.

48 É grande martírio aquele

49 A sua sorte é a dele

$50 \mathrm{E}$ a sorte dele é a sua!

51 Disso, eu já vivo ciente:

$52 \mathrm{Se}$, na cidade, o operário

53 Trabalha constantemente

54 Por um pequeno salário,

55 Lá no campo, o agregado

56 Se encontra subordinado

57 Sob o jugo do patrão,

58 Padecendo vida amarga,

59 Tal qual o burro de carga,

60 Debaixo da sujeição. 
61 Camponeses, meus irmãos,

62 E operários da cidade,

63 É preciso dar as mãos

$64 \mathrm{E}$ gritar por liberdade.

$65 \mathrm{Em}$ favor de cada um,

66 Formar um corpo comum,

67 Operário e camponês!

68 Pois, só com essa aliança,

69 A estrela da bonança

70 Brilhará para vocês!
71 Uns com os outros se entendendo,

72 Esclarecendo as razões.

$73 \mathrm{E}$ todos, juntos, fazendo

74 Suas reivindicações!

75 Por uma Democracia

76 De direito e garantia

77 Lutando, de mais a mais!

78 São estes os belos planos,

79 Pois, nos Direitos Humanos,

80 Nós todos somos iguais!

“O agregado e o operário" encontra-se em Ispinho e Fulô (2005, p. 298) e se apresenta em décimas, modelo de estrofe mais frequente na obra de Patativa do Assaré: "Dos 525 poemas considerados, 271 foram escritos em forma de décimas” (ANDRADE, 2008, p. 112). Nossa pesquisa, por sua vez, calculou 546 poemas patativanos, sendo 285 em décimas. Como já discutido, as décimas empregadas pelo poeta não são todas iguais entre si no que se refere ao sistema de rimas. Constatam-se quatro esquemas rímicos diferentes (ver capítulo "Influências da poesia popular brasileira e da poesia erudita").

O poema analisado é composto a partir do esquema de rimas tipo A ( $\mathrm{a}$ b a b c c d e e d) e Andrade observa que as rimas de tipo A, que têm primazia na obra de Patativa do Assaré, são encontradas de forma similar em um único poema de Castro Alves (“O navio negreiro"), não sendo verificadas nem nos poetas do cordel ou demais poetas literários que influenciaram o sertanejo. Entretanto, trata-se de uma ocorrência isolada na obra do poeta dos escravos, já que tal décima está presente em apenas treze estrofes do poema. $\mathrm{O}$ pesquisador conclui, tendo em vista a raridade deste tipo de décima no conjunto das obras consultadas, em contraste com a sua ampla utilização em Patativa do Assaré, que o tipo estrófico majoritário na obra do poeta sertanejo é uma raridade na poesia.

Seus versos revelam a similar condição de vida precária da população pobre da cidade e do sertão. O sujeito poético apresenta-se como agricultor e como pertencente ao grupo daqueles que vivem à margem da sociedade. Assim, busca unir esses dois polos (o trabalhador da cidade e o camponês do sertão) contra o opressor (o patrão e o fazendeiro).

"O agregado e o operário" apresenta um sujeito poético que se denomina matuto, caboclo e poeta roceiro. Tais condições lhe dão o direito de se tornar companheiro do penar do povo oprimido: "Eu sempre fui companheiro / Da dor, dia mágoa e do pranto" (v. 6 e 7). 
Vale notar mais um erro de edição nesse último verso; provavelmente, a grafia correta seria "da mágoa".

Na segunda estrofe esse sujeito traz uma apresentação mais detalhada de si e de seu canto: "Sou poeta agricultor, / Do interior do Ceará" (v. 11 e 12) e "Canto aqui e canto acolá" (v. 14), isto é, seu canto representa todos os oprimidos; não apenas a sua vida e o seu povo sertanejo, mas ainda o operário e o mendigo da cidade.

Como já observado em outras poesias patativanas, o sujeito poético sempre está ao lado dos marginalizados, ou seja, sempre se reconhece nas classes pobres em consonância com a condição de agricultor de Antonio Gonçalves da Silva. Entretanto, "O agregado e o operário" se distancia de outro grande poema de Patativa, "Cante lá que eu canto cá", já que neste, o sujeito poético declara que seu local de canto é o sertão, estabelecendo as oposições entre rural e urbano, poeta popular e poeta erudito, já que a poesia, segundo ele, vem da observação e da experiência:

\author{
Poeta, cantô de rua, \\ Que na cidade nasceu, \\ Cante a cidade que é sua, \\ Que eu canto o sertão que é meu. \\ Se aí você teve estudo, \\ Aqui, Deus me ensinou tudo, \\ Sem de livro precisá \\ Por favô, não mêxa aqui, \\ Que eu também não mexo aí, \\ Cante lá, que eu canto cá. \\ [...] \\ Sua rima, inda que seja \\ Bordada de prata e de ôro, \\ Para a gente sertaneja \\ É perdido este tesôro. \\ Com o seu verso bem feito, \\ Não canta o sertão dereito, \\ Porque você não conhece \\ Nossa vida aperreada. \\ E a dô só é bem cantada, \\ Cantada por quem padece ${ }^{58}$.
}

O sujeito poético de "Cante lá que eu canto cá" acredita que o poeta da cidade não é capaz de cantar a dor do sertanejo, pois não a presencia, enquanto ele, na condição de matuto, lida com ela diariamente. Todavia, em "O agregado e o operário", o poeta popular canta não

${ }^{58}$ (PATATIVA DO ASSARÉ. Inspiração nordestina. São Paulo: Hedra, 2006a, p. 275-276). 
apenas a vida cabocla, mas ainda o padecer do trabalhador urbano, ou seja, "canta aqui e acolá”. Observa-se ainda uma relação dialógica entre o sertão e a cidade, já que o padecer do sertanejo se compara ao sofrimento dos marginalizados do sistema urbano. Desse modo, enquanto, no contexto rural, Patativa do Assaré apresenta o camponês explorado pelo fazendeiro; no contexto urbano, o poeta aponta, aos seus leitores, o proletariado, camada mais baixa da sociedade burguesa, também oprimido pelos patrões.

Já se sabe que na poética social patativana emerge não somente a representação do sertão, isto é, o ambiente rural, mas também a cidade e o contexto urbano. Apesar do locus de origem do poeta matuto possuir um lugar de destaque nas suas denúncias, Patativa do Assaré também contempla o espaço da urbe com sua marginalização e exploração. Assim, torna-se interessante investigar o engajamento social nas figurações do rural e do urbano na obra do sertanejo.

Patativa do Assaré aborda os oprimidos da urbe, já que muitos destes são os retirantes nordestinos que sofreram com a diáspora impositiva da seca e passaram a engrossar a massa que vive nas periferias dos grandes centros urbanos. Observa-se que o projeto poético patativano é elucidar os problemas sociais que existem em todos os contextos, nas figurações do rural ou do urbano, produzindo um canto de luta pela justiça e pela igualdade sociais.

Para o poeta matuto, revelar a opressão vivida pelo retirante nordestino na cidade é papel do intelectual popular, tendo em vista que a igualdade social deve atingir todos os espaços para tornar-se plena.

"Lição do pinto" e "O agregado e o operário" apresentam similaridades, tendo em vista que retratam a luta de classes como luta política por democracia e igualdade. Deve-se observar que não se trata de uma visão de país cindido por desigualdades regionais, mas sim a percepção de antagonismos de classe, que geram grupos sociais de excluídos e de privilegiados, tanto no sul como no norte, no campo ou na cidade. O proletariado, a camada inferior da sociedade burguesa, sofre a mesma exploração e, por conseguinte, está na mesma escala social que o camponês do interior do país.

Como o título já antecipa, os interlocutores desse último poema são os operários e os camponeses. Patativa do Assaré afirma, na terceira estrofe, que busca corrigir, em seu "modesto poema" (em consonância com a ideia de poesia popular e matuta), os problemas sociais do país, tanto no sertão (camponês sem terra), quanto na urbe (trabalhador que sofre necessidade).

$\mathrm{Na}$ quarta estrofe, o sujeito poético aproxima os dois interlocutores que passam necessidades "Os agregados sem terra / E os operários sem casa" (v. 39 e 40). Assim, ele 
busca unir, com base na verdade, essas duas massas que ainda não se reconhecem como iguais: "Vão no mesmo itinerário / Sofrendo a mesma opressão / Nas cidades o operário / E o camponês no sertão" (v. $31-34)$.

O poeta ainda compara o padecer dos dois interlocutores, operário que trabalha por um pequeno salário e o camponês que é subordinado ao jugo do patrão. Patativa do Assaré então pede a fraternidade e a aliança entre eles, pois se todos juntos reivindicarem a democracia, alcança-se a justiça social.

A perspectiva social na poesia patativana passa pela discussão da luta de classes não apenas entre camponês e fazendeiro, "mas antes em termos de alianças entre vários grupos sociais que, de um lado dominam e dirigem a vida econômica e social, e de outro são subordinados e dirigidos" (BOTTOMORE, 1993, p. 224). No poema "O agregado e o operário", Patativa do Assaré apresenta, segundo ele, os dois maiores desvalidos, que, infelizmente, não se unem, já que o operário, por morar no centro urbano, considera-se superior ao camponês:

Eles são iguais, mas eles se sentem diferentes. Só por morar no meio urbano, viu, pensa que é, que está além do agregado. Eu procuro unir os dois, mas vendo que há sempre uma dificuldade. O pobre do agregado, humilde, se sente mesmo que é menor do que o operário (FEITOSA, 2001, p. 43).

Patativa do Assaré, apesar de nunca ter lido Marx e Engels, defende ideais similares ao comunismo ao julgar que todos os homens são irmãos na aproximação que estabelece entre o agregado, que vive em uma sociedade feudal, e o operário, que pertence à sociedade burguesa. Nesse contexto, vale lembrar a observação presente no Manifesto comunista (1848):

\footnotetext{
A sociedade burguesa moderna, que brotou das ruínas da sociedade feudal, não aboliu os antagonismos de classe. Não fez mais do que estabelecer novas classes, novas condições de opressão, novas formas de luta em lugar das que existiram no passado (2007, p. 40).
}

Todas as sociedades se basearam no antagonismo entre classes opressoras e classes oprimidas, todavia, para oprimir uma classe é preciso poder garantir-lhe condições que lhe permitam, pelo menos, uma existência de escravo. O preço que se paga para o trabalhador é o mínimo de salário que garanta os meios de subsistência necessários para que o operário viva, ou seja, o que este obtém com seu trabalho é o estritamente necessário para a mera conservação e reprodução de sua vida. 
Em "Os trabalhadores pobres” (1962), de Hobsbawm, discute-se a inquestionável condição de explorado do operário perante o mecanismo social da burguesia, o qual é profundamente cruel, injusto e desumano:

[...] não pode haver nenhuma dúvida de que todos aqueles que pensavam um pouco sobre a sua situação - isto é, que [não] aceitavam as aflições dos pobres como parte do destino e do eterno rumo das coisas - consideravam que o trabalhador era explorado pelo rico, que cada vez mais enriquecia, ao passo que os pobres ficavam ainda mais pobres. E que os pobres sofriam porque os ricos se beneficiavam (2002, p. 290).

O mesmo acontece com o trabalhador do campo que, ao não possuir sua própria terra, vive subordinado ao fazendeiro detentor da produção agrícola. Para sua subsistência, o camponês, na condição de agregado, trabalha e cultiva na terra de outrem que lhe explora e ainda detém a maior parte da plantação. O desejo de Patativa do Assaré é suprimir o caráter miserável da vida dos trabalhadores do campo e da urbe, os quais só vivem para assegurar os interesses das classes dominantes:

\section{Somente o amor é capaz \\ E dentro de um país faz \\ Um só povo bem unido, \\ Um povo que gozará \\ Porque assim, já não há \\ Opressor nem oprimido ${ }^{59}$.}

O poeta matuto reconhece a distinção entre os detentores da terra ou da máquina para o trabalho (o fazendeiro e o patrão da fábrica, respectivamente), e o explorado, cuja única saída é vender-se como mão de obra barata, pois tanto o agregado, quanto o proletariado (a classe dos operários modernos), só podem viver se encontrarem trabalho, vendendo-se, assim, diariamente como mercadoria:

O operário torna-se um simples apêndice da máquina e dele só se requer o manejo mais simples, mais monótono, mais fácil de aprender. Desse modo, o custo do operário se reduz, quase exclusivamente, aos meios de subsistência que lhe são necessários para viver e perpetuar sua espécie (MARX; ENGELS, 2007, p. 18).

Para Gilmar de Carvalho, o socialismo cristão patativano, utópico ou não, “apontava para uma justiça social, para uma correção romântica das dores do mundo e para as relações

${ }^{59}$ (PATATIVA DO ASSARÉ, 2005, p. 41). 
de poder baseadas no consenso e nunca na força" (2009, p. 134). Do mesmo modo, Hobsbawm aponta para uma sociedade totalmente diversa, em oposição aos ideais de seus opressores:

\footnotetext{
Seria cooperativa e não competitiva, coletivista e não individualista. Seria "socialista", e representaria não o eterno sonho da sociedade livre, que os pobres sempre levam no recôndito de suas mentes, mas na qual só pensam em raras ocasiões de revolução social generalizada, e sim uma alternativa praticável e permanente para o sistema em vigor (p. 291-292).
}

A partir de sua obra, pode-se reconhecer, no poeta, um empenho na representação dos pobres, no entanto, vale ressaltar que não há distância social entre eles e Patativa do Assaré, uma vez que o repentista e cantador caboclo fora filho de agricultores no interior do Ceará, possuindo pouca instrução: "Patativa do Assaré foi agricultor-poeta. Na mesma terra em que cultivou o grão de milho, de feijão, a raiz da mandioca, a semente de algodão, também semeou a palavra vital” (BRITO, 2009, p. 180). Portanto, a poética patativana não apresenta uma perspectiva distanciada entre o eu lírico e aqueles por ele representado, pois o "Nordeste flagelado" é também o seu lugar social:

Se não sabe, escute agora, Que eu vô contá minha história,

Tenha a bondade de ouvi:

Eu sou da crasse matuta,

Da crasse que não desfruta

Das riqueza do Brasil $^{60}$.

Os versos acima pertencem ao poema "Seu dotô me conhece?", um dos muitos poemas nos quais o sujeito lírico se identifica como homem simples em oposição ao doutor da capital com quem dialoga. Nestes versos, novamente Patativa do Assaré ultrapassa as fronteiras que separam o sertão dos grandes centros urbanos, estabelecendo como única distinção a que existe entre o povo marginalizado e oprimido, seja do campo, seja da cidade (ao qual o sujeito lírico se identifica), e o doutor que representa a classe dominante e opressora:

${ }^{60}$ (PATATIVA DO ASSARÉ. Cante lá que eu canto cá. Petrópolis: Vozes, 2014, p. 114). 
Sou aquele que conhece As privação que padece O mais pobre camponês;

Tenho passado na vida De cinco mês em seguida Sem comê carne uma vez.

Sou o que durante a semana, Cumprindo a sina tirana, $\mathrm{Na}$ grande labutação

Pra sustentá a famia Só tem direito a dois dia O resto é pra o patrão. $[\ldots]$

Sou o sertanejo que cansa

De votá, com esperança

Do Brasil ficá mió; Mas o Brasil continua $\mathrm{Na}$ cantiga da perua Que é: pió, pió, pió...

Sou o mendigo sem sossego Que por não achá emprego Se vê forçado a seguí Sem direção e sem norte, De porta em porta a pedí. [...]

Senhô dotô , não se enfade Vá guardando essa verdade Na memória, pode crê Que sou aquele operário Que ganha um nobre salário Que não dá nem pra comêt $\hat{~}^{61}$.

Observa-se que o sertanejo, o camponês, o mendigo e o operário pertencem ao mesmo grupo humano que sofre as mais diversas privações. Com exceção do morador de rua, todos se vendem enquanto mercadoria para o patrão com a necessidade de sustentar a si e a família. Em troca, recebem um salário, o qual, entretanto, é tão ínfimo que mau garante sua subsistência.

Assim como neste poema, em "O agregado e o operário" há constantemente a necessidade de se aproximar o sujeito lírico da instância biográfica, pois o conjunto de vivências abordado por este é o mesmo experimentado por Antonio Gonçalves da Silva, o que permite a Patativa do Assaré cantar com emoção o seu querido sertão e a vida de sua gente (v.

${ }^{61}$ (PATATIVA DO ASSARÉ. Cante lá que eu canto cá. Petrópolis: Vozes, 2014, p. 114-116). 
18, 19 e 20). O drama social compartilhado por agregados e operários só pode ser combatido a partir da aliança entre estes: "Pois só com esta aliança / A estrela da bonança / Brilhará para vocês" (v. 68 - 70). Patativa do Assaré, no citado poema, busca superar a distância entre essas duas camadas de uma mesma classe explorada que ainda não se reconhecem como iguais e esclarecer que apenas a solidariedade para revelar um ser coletivo é capaz de alcançar mudanças.

O sujeito poético, assim, coloca agregados e operários como "irmãos distantes" que sofrem a mesma necessidade: "A sua sorte é a dele / E a sorte dele é a sua" (v. 49 e 50). O poema constitui-se a partir da comparação do padecer dos que vivem subordinados ao patrão por um pequeno salário. Patativa do Assaré, portanto, aborda a exploração destes que "Padecendo vida amarga, / Tal qual o burro de carga" "[...] queimam a mesma brasa / e vivem na mesma guerra" (v. 58, 59, 37 e 38).

$\mathrm{Da}$ mesma forma, o poema "Eu quero" busca unir os diferentes grupos de marginalizados da sociedade. Seus versos pedem a reforma agrária no campo e o fim da exploração do operário na cidade:

Quero um chefe brasileiro

Fiel, firme e justiceiro

Capaz de nos proteger

Que do campo até à rua

O povo todo possua

$\mathrm{O}$ direito de viver

Quero paz e liberdade

Sossego e fraternidade

Na nossa pátria natal

Desde a cidade ao deserto

Quero o operário liberto

Da exploração patronal

Quero ver do Sul ao Norte

O nosso caboclo forte

Trocar a casa de palha

Por confortável guarida

Quero a terra dividida

Para quem nela trabalha ${ }^{62}$.

${ }^{62}$ (PATATIVA DO ASSARÉ. Cante lá que eu canto cá. Petrópolis: Vozes, 2014, p. 116-117). 
Nos versos de "Aqui tem coisa", poema que abre o livro com título homônimo, o poeta já demonstra o conteúdo dramático de sua obra, que abraça não somente o seu povo camponês do sertão, mas ainda o operário da cidade:

\section{Com muita simplicidade \\ Nesta linguagem singela \\ A pura realidade \\ Aqui Tem Coisa revela, \\ Fala sobre o sofrimento, \\ Do grande padecimento \\ Da pobre Classe Operária \\ E do agregado sem nome \\ Que vive sofrendo fome \\ Pedindo Reforma Agrária ${ }^{63}$}

Os dois interlocutores destes versos representam, em toda a obra patativana, os maiores explorados de nosso país. Em um primeiro momento, pode-se pensar que Patativa do Assaré coloca em dois planos distintos - o que é típico de sua poética, isto é, estabelecer antagonismos -, o agregado e o operário, entretanto, ambos se constituem como mão de obra mal remunerada. Além do coronel latifundiário, aquele que se opõe ao trabalhador camponês é o doutor da capital, pois este, na cidade, ignora o padecer do agregado no sertão, como podemos verificar nos versos de "Apelo de um agricultor":

Sei que o dotô inguinora,

E tem bastante razão,

Pois quem na cidade mora

Não vai pensá no sertão;

E por isto eu vou assim

Contá tin-tin por tin-tin

Como é que tenho vivido,

Minhas razão eu dizendo

O dotô fica sabendo

Quanto eu tenho lhe servido ${ }^{64}$.

Em contrapartida, se o operário também ignora o sofrimento do sertanejo é por ainda não reconhecer que, assim como o homem do campo, ele é igualmente explorado pelo patrão. Logo, o canto de "O agregado e o operário" tem como função despertar não somente o camponês para a luta, mas, principalmente, o trabalhador urbano, unindo os desvalidos do Norte e do Sul.

${ }^{63}$ (PATATIVA DO ASSARÉ. Aqui tem coisa. São Paulo: Hedra, 2012a, p. 9).

${ }^{64}$ (PATATIVA DO ASSARÉ. Cante lá que eu canto cá. Petrópolis: Vozes, 2014, p. 167). 
Patativa do Assaré não espera, como resultado de suas lutas, o êxito imediato, mas a união cada vez mais ampla dos trabalhadores rurais e urbanos: "É preciso dar as mãos / Cheios de fraternidade, / Em favor de cada um / Formar um corpo comum" (v. 63 - 66) e "Uns com os outros se entendendo, / Esclarecendo as razões. / E todos, juntos, fazendo / Suas reivindicações! / Por uma Democracia / De direito e garantia / Lutando, de mais a mais," (v. 71 - 77). 


\section{CONSIDERAÇÕES FINAIS}

Longe de ser um simples entretenimento, uma distração reservada às pessoas educadas, ela [a literatura] permite que cada um responda melhor à sua vocação de ser humano. 
O filósofo e linguista búlgaro Tzvetan Todorov afirma que "a literatura é pensamento e conhecimento do mundo psíquico e social em que vivemos" (2010, p. 77). Com base nesta declaração, pode-se inferir que a obra literária coloca-se como um instrumento de reorganização do universo à nossa volta, a partir do momento em que se constitui como uma revelação do mundo real, contudo, de forma mais plena e bela.

Nesse contexto, podemos pensar na poética popular de Patativa do Assaré, o qual tinha total consciência de que a produção cultural tem, necessariamente, um caráter político e social. Como poeta matuto, o sertanejo representou não somente a língua, os personagens e o cotidiano do mundo rural e urbano, mas também as aspirações sociais, as reivindicações políticas e econômicas de seu povo.

Para o poeta, o papel do intelectual não significa uma ruptura com a condição de trabalhador. Patativa do Assaré derruba a construção ideológica que separa trabalho intelectual de trabalho braçal. Assim, o sertanejo se valeu de sua condição popular para apontar a verdade e as injustiças sociais, pois, diferentemente dos "poetas de classe", ele compartilha a sabedoria de vida sertaneja ao se assumir como homem do trabalho na lavoura. O poeta conviveu com o cotidiano de sofrimento de seus companheiros matutos e, assim, segundo ele, pode alcançar o patamar de intérprete das mazelas de seu povo.

Patativa do Assaré "fez dos noventa e três anos de sua vida um longo poema épico sobre a terra, o trabalho, e as condições de vida de sua (nossa) gente" (CARVALHO, 2002, p. 8). O poeta sempre esteve em comunhão com a sua terra, tendo em vista que sempre fora um camponês de mão grossa e fina sensibilidade ao versificar pela reforma agrária, pelo socialismo e contra a exclusão e a miséria. Logo, lutava pela construção de um mundo melhor pautado nos ideais de seu socialismo-cristão, tornando-se um utópico.

Ao traduzir para a forma poética o seu "torrão natal", o poeta revive as belezas nordestinas no que concerne à natureza, crenças e valores, sem deixar de analisar, no entanto, os problemas da região. As belezas e desgraças de um povo ocupam o mesmo espaço em seus versos. Patativa do Assaré, ao mesmo tempo em que apresenta um Nordeste simples, pobre e carente, contribui para representar uma região nordestina de grande tradição cultural, conquistando um lugar de fala não apenas em nível nacional, mas ainda internacional, tendo em vista que o poeta matuto é objeto de estudo na França e na Inglaterra.

Patativa do Assaré busca demonstrar que a causa do atraso nordestino não decorre unicamente das intempéries climáticas, isto é, que a seca não é a maior antagonista; a ela somam-se o governo e o latifúndio. O poeta demonstra não concordar com o determinismo alienante e acredita que a pobreza não decorre apenas do meio físico, já que a exploração é a 
maior opressora no contexto moderno. Desse modo, frente ao descaso sofrido pelo sertanejo, Patativa do Assaré cobra proteção e medidas produtivas por parte do Estado.

O espaço desenhado em seus versos é quase sempre o do Nordeste e, no Nordeste, o do sertão. Esse espaço abstrato surge abordado por temas e imagens ligados à própria cultura popular: as festas de santos ("A fogueira de São João"), a fé cristã ("Se existe inferno"), a vida simples do sertão e suas superstições ("No meu sertão"). Entretanto, diferentemente de outros poetas populares, Patativa do Assaré dedicou-se à composição de versos nos quais o povo marginalizado e oprimido foi o principal personagem. Sua poética engajada é marcada por temas que revelam as desigualdades existentes entre o doutor da capital e o sertanejo (Seu Dotô me conhece?”), o “dono da casa caiada" e o agregado (“O agregado”), os políticos e os “ingênuos eleitores” (“A política), sempre em busca da justiça social.

O poeta se vale de duas modalidades linguísticas opostas: a norma padrão e a variante matuta, as quais representam o embate de classes entre aqueles que dominam a língua padrão e desfrutam de privilégios ("Brasi de cima"), e aqueles que lidam com as privações de seus direitos básicos, como o acesso a educação, e, portanto, restringem-se à linguagem popular ("Brasi de baxo"). A língua matuta se faz presente sem deboche, representando a sabedoria cabocla. Tal variante é utilizada como instrumento de luta de classe, pois, através do diálogo, o poeta matuto enfrenta, sem qualquer sentimento de inferioridade, o doutor da capital. Logo, a palavra e a ideologia revelam-se como significação social na produção literária do poeta.

Desse modo, constatam-se, em sua obra, constantes dicotomias entre oprimido e opressor, linguagem culta e linguagem matuta, sertão e grandes centros urbanos etc. Seus versos se configuram segundo um eixo antagônico: dois sujeitos representativos de duas condições sociais antagônicas, dois espaços socioculturais contrastivos ou dois diferentes registros em um mesmo projeto poético. Patativa do Assaré procura descrever tais temas, por meio da oposição, no intuito de denunciar a relação de complementariedade entre privilégio e privação como condição fomentadora do desequilíbrio e da desigualdade.

Apesar de os críticos afirmarem que Patativa do Assaré, como grande poeta social nordestino, revelou as condições de vida de seu povo sertanejo, transferindo, para sua poesia, a peleja do caboclo, cheio de esperanças e de coragem, diante da seca, do patrão e da metrópole, pode-se concluir que o poeta matuto foi muito além ao representar não apenas seu Nordeste flagelado, como também a massa pobre dos grandes centros urbanos. A verdade patativana, sempre pautada na justiça e na igualdade, não se restringe ao contexto rural, mas abraça também a cidade: 
Eu sô caboco sisudo,

Caboco mesmo de raça,

Eu não acredito in tudo,

Nem conto o que não se passa.

Se eu as vez, falando peco,

É pruque sou nalfabeto,

Mais porém amo a verdade,

E mesmo sem tê iscrita

A minha históra é bonita

Do campo inté na cidade ${ }^{65}$

Embora explore a identidade regional de sua região, Patativa do Assaré, em muitos versos, buscou também desconstruir a percepção do Nordeste como uma unidade e um espaço à parte no país, ou seja, levou a quebra da velha homogeneidade nordestina pensada em oposição ao Sul. Em poemas analisados, como "O agregado e o operário", o autor aproxima os trabalhadores dos dois extremos do país, o camponês do sertão e o proletariado dos grandes centros urbanos.

Como já abordado, o próprio poeta revelava, abertamente, sua pretensão de se tornar porta-voz e educador de sua gente, já que seu canto despertaria seu povo para a consciência da opressão, como um "grito de alerta". Além disso, o poeta também busca avivar o interesse da região Sul para as tradições de seu povo e, principalmente, chamar atenção para seus problemas. Dessa forma, como intelectual orgânico, Patativa do Assaré assume a função de intermediário entre o povo nordestino e o "doutor da capital".

A partir de elementos de denúncia e de contestação, em sua obra, temos a síntese das condições sociais, crenças, saberes e imaginário de um povo. Os grandes temas da obra patativana estão representados na sua ligação com a terra, na ideia de cidadania e fé e, principalmente, na questão social. Sua poesia comprometida com as questões político-sociais revela o grau de consciência deste sertanejo que vive em uma condição costumeiramente considerada como rústica e atrasada, valendo-se dela para denunciar a situação de penúria, principalmente, da sua região nordestina. O sertanejo revela que a ausência do Estado condena o sertão ao atraso, enquanto as campanhas eleitorais perpetuam privilégios à custa da miséria e do voto inconsciente.

A poética patativana, vista pelo autor como "poesia rude, poesia do povo" (PATATIVA DO ASSARÉ apud ANDRADE, 2004, p. 33), apresenta uma grande relevância para a literatura brasileira, tendo em vista a conquista de espaço para a cultura nordestina nos meios acadêmicos, contribuindo para desconstruir o estabelecido complexo de inferioridade

${ }^{65}$ (PATATIVA DO ASSARÉ. Cante lá que eu canto cá. Petrópolis: Vozes, 2014, p. 139). 
da produção popular. O poeta matuto busca afirmar o que considera "uma cultura marginalizada", ajudando-a a se atualizar e reafirmar em outro nível, pois longe de ser uma visão do passado, é uma visão do presente de um grupo social e regional silenciado. 


\section{REFERÊNCIAS BIBLIOGRÁFICAS}

ALBUQUERQUE JUNIOR, D. M. de. A invenção do nordeste e outras artes. São Paulo: Cortez, 2009.

ALENCAR, M. S. M. O léxico regional e o prestígio social das palavras. In: CARVALHO, G. (Org.). Patativa em sol maior: treze ensaios sobre o poeta pássaro. Fortaleza: UFC, 2009. AGUIAR, R. H. de; CONTE, D. Patativa do Assaré: o canto ilimitado. In: PUHL, P. R.; SARAIVA, J. A. (Org.). Processos culturais e suas manifestações. Novo Hamburgo: Universidade Feevale, 2013.

ANDRADE, C. H. S. Patativa do Assaré: As razões da emoção (capítulos de uma poética sertaneja). Fortaleza: Editora UFC / São Paulo: Nankin Editorial, 2004.

Aspectos e impasses da poesia de Patativa do Assaré. Tese de Doutoramento. São Paulo: Universidade de São Paulo, 2008.

Entre a dor e o riso: sonhos desfeitos, amores truncados, ganhos improváveis. Notas sobre humor e ironia em Patativa do Assaré. In: CARVALHO, G. (Org.). Patativa em sol maior: treze ensaios sobre o poeta pássaro. Fortaleza: UFC, 2009.

AYALA, M; AYALA, M. I. N. Cultura popular no Brasil: perspectiva de análise. São Paulo: Editora Ática, 1987.

BOSI, A. "Poesia resistência". In: O ser e o tempo da poesia. São Paulo: Companhia das Letras, 2000.

. "O trabalho dos intelectuais, segundo Gramsci”. In: Céu, inferno: ensaios de crítica literária e ideologia. São Paulo: Duas cidades; Editora 34, 2003, p. 409-422.

BOTTOMORE, T. (org). Dicionário do pensamento marxista. Rio de Janeiro: Jorge Zahar, 1993.

BRITO, A. I. A. "Patativa do Assaré: porta-voz do sertão". Conexão - Comunicação e Cultura, UCS, Caxias do Sul, v.8, n. 16, jul./dez. 2009, p. 179-193.

CALLADO, A. Os industriais da seca e os “Galileus" de Pernambuco. Rio de Janeiro, Ed. Civilização Brasileira, 1960.

CANDIDO, A. “O direito à literatura”. In: Vários escritos. São Paulo/Rio de Janeiro: Duas Cidades/Ouro sobre Azul, 2004.

Literatura e sociedade: estudos de teoria e história literária. Rio de Janeiro: Ouro sobre azul, 2011.

CARIRY, R.; BARROSO, O. "Patativa do Assaré, sua poesia, sua vida", entrevista em Cultura insubmissa. Fortaleza: Nação Cariri, 1982. 
CARVAlHO, G. Patativa poeta pássaro do Assaré. Fortaleza: Omni, 2002a.

Patativa do Assaré: pássaro liberto, 2002b.

Cem Patativa. Fortaleza: Omni, 2009.

. Patativa do Assaré: um poeta cidadão. São Paulo: Expressão Popular,

2011.

CASCUDO, L. C. Literatura oral no Brasil. São Paulo: Global, 2006.

CAVIGNAC, Julie. A literatura de cordel no Nordeste do Brasil. Da história escrita ao relato oral. Trad. Nelson Patriota - Natal: Editora da UFRN, 2006.

COHN, A. Crise regional e planejamento: o processo de criação da Sudene. São Paulo: Ed. Perspectiva, 1978.

DEBS, S (Org.). Patativa do Assaré visto por Rosemberg Cariry ou a construção de um mito. In: CARVAlHO, G. (Org.). Patativa em sol maior: treze ensaios sobre o poeta pássaro. Fortaleza: UFC, 2009.

Patativa do Assaré: uma voz do Nordeste. São Paulo: Hedra, 2011.

FEITOSA, T. (Org.). Patativa do Assaré: Digo e não peço segredo. São Paulo: Escrituras Editora, 2003.

FIGUEIREDO FILHO, J. de. Patativa do Assaré: novos poemas comentados. Secretaria da Cultura do Estado do Ceará, 1970.

FRANÇA JR., L.C. Patativa do Assaré: um artista da fome? In: CARVALHO, G. (Org.).

Patativa em sol maior: treze ensaios sobre o poeta pássaro. Fortaleza: UFC, 2009.

FURTADO, C. A pré-revolução brasileira. Rio de Janeiro: Fundo de cultura, 1962.

GALVÃO, Ana Maria de Oliveira. Cordel: leitores e ouvintes. Belo Horizonte: Autêntica, 2006.

GRAMSCI, A. Literatura e vida nacional. São Paulo: Civilização Brasileira, 1978.

Os intelectuais e a organização da cultura. Trad. Carlos Nelson Coutinho.

Rio de Janeiro: Civilização brasileira, 1982.

HOBSBAWM, E. J. “Os trabalhadores pobres”. In: A era das revoluções: 1789 - 1848. São Paulo: Editora Paz e Terra, 2002.

LEMAIRE, R. Reler Patativa do Assaré: redescobrir um mundo. In: CARVALHO, G. (Org.).

Patativa em sol maior: treze ensaios sobre o poeta pássaro. Fortaleza: UFC, 2009.

LOPES, P. C. História e esperanças de um artista do povo. Introdução. In: ANDRADE, C. H.

S. Patativa do Assaré: As razões da emoção (capítulos de uma poética sertaneja). Fortaleza: Editora UFC / São Paulo: Nankin Editorial, 2003.

MARX, K. H.; ENGELS, F. Manifesto comunista. São Paulo: Boitempo editorial, 2007. 
PATATIVA DO ASSARÉ. Ispinho e Fulô. São Paulo: Hedra, 2005.

- Inspiração nordestina. Coleção de literatura popular. São

Paulo: Hedra, 2006a.

- Melhores poemas: Patativa do Assaré. Seleção de Cláudio Portella. São Paulo: Global, 2006b.

. Aqui tem coisa. São Paulo: Hedra, 2012a.

. Cordéis. Coleção nordestina. Organização e apresentação Gilmar de Carvalho. Fortaleza: Edições UFC, 2012b.

. Cante lá que eu canto cá: filosofia de um trovador nordestino.

Petrópolis: Vozes, 2014.

ROMERO, Silvio. Estudos sobre a poesia popular do Brasil. Petrópolis: Editora Vozes em convênio com o Governo do Estado de Sergipe, 1977.

SEMERARO, G. Intelectuais “orgânicos” em tempos de pós-modernidade. In: Caderno Cedes - Campinas, vol. 26, n. 70, p. 373-391, set/dez. 2006.

TAVARES JÚNIOR, L. "Patativa: um cordelista revisitado". In: PATATIVA DO ASSARÉ. Cordéis. Coleção nordestina. Organização e apresentação Gilmar de Carvalho. Fortaleza: Edições UFC, 2012b.

TODOROV, T. A literatura em perigo. Rio de Janeiro: DIFEL, 2010. 
ANEXOS 
ANEXO A - TABELA DE POEMAS ${ }^{66}$

\begin{tabular}{|c|c|c|c|c|}
\hline & Título do poema & Livro(s) & Estrofe & Linguagem \\
\hline 1 & A cobra falou & $\begin{array}{l}\text { Balceiro / } \\
\text { Melhores Poemas }\end{array}$ & Quartetos & $\begin{array}{l}\text { Norma } \\
\text { padrão }\end{array}$ \\
\hline 2 & $\begin{array}{l}\text { A Derrota de Pedro Topa } \\
\text { Tudo }\end{array}$ & $\begin{array}{l}\text { Melhores Poemas / } \\
\text { Balceiro } 2\end{array}$ & Septilhas & $\begin{array}{l}\text { Norma } \\
\text { padrão }\end{array}$ \\
\hline 3 & A Derrota de Zé Côco & Ispinho e Fulô & $\begin{array}{l}\text { Décimas - Tipo } \\
\text { A }\end{array}$ & $\begin{array}{l}\text { Variante } \\
\text { matuta }\end{array}$ \\
\hline 4 & A Enfermeira do Pobre & Ispinho e Fulô & $\begin{array}{l}\text { Sextilha } \\
\text { Moderna }\end{array}$ & $\begin{array}{l}\text { Norma } \\
\text { padrão }\end{array}$ \\
\hline 5 & A Escrava do Dinheiro & $\begin{array}{l}\text { Inspiração } \\
\text { nordestina / Cante } \\
\text { lá que eu canto cá / } \\
\text { Melhores Poemas } \\
\end{array}$ & $\begin{array}{l}\text { Décimas - Tipo } \\
\text { C }\end{array}$ & $\begin{array}{l}\text { Variante } \\
\text { matuta }\end{array}$ \\
\hline 6 & A Estrada da minha Vida & $\begin{array}{l}\text { Inspiração } \\
\text { nordestina / Cante } \\
\text { lá que eu canto cá / } \\
\text { Aqui tem coisa / } \\
\text { Melhores Poemas }\end{array}$ & $\begin{array}{l}\text { Décimas - Tipo } \\
\text { A }\end{array}$ & $\begin{array}{l}\text { Norma } \\
\text { padrão }\end{array}$ \\
\hline 7 & A Festa da Maricota & $\begin{array}{l}\text { Inspiração } \\
\text { nordestina / Cante } \\
\text { lá que eu canto cá }\end{array}$ & $\begin{array}{l}\text { Décimas - Tipo } \\
\text { A }\end{array}$ & $\begin{array}{l}\text { Variante } \\
\text { matuta }\end{array}$ \\
\hline 8 & A Festa da Natureza & $\begin{array}{l}\text { Cante lá que eu } \\
\text { canto cá }\end{array}$ & Oitavas & $\begin{array}{l}\text { Variante } \\
\text { matuta }\end{array}$ \\
\hline 9 & $\begin{array}{l}\text { A Filosofia de um } \\
\text { Trovador Sertanejo }\end{array}$ & $\begin{array}{l}\text { Inspiração } \\
\text { nordestina / Cante } \\
\text { lá que eu canto cá }\end{array}$ & $\begin{array}{l}\text { Décimas - Tipo } \\
\text { C }\end{array}$ & $\begin{array}{l}\text { Variante } \\
\text { matuta }\end{array}$ \\
\hline 10 & A Fogueira de São João ${ }^{68}$ & $\begin{array}{l}\text { Inspiração } \\
\text { nordestina / Cante } \\
\text { lá que eu canto cá / } \\
\text { Melhores Poemas }\end{array}$ & Oitavas & $\begin{array}{l}\text { Variante } \\
\text { matuta }\end{array}$ \\
\hline 11 & A Fonte Milagrêra & Ispinho e Fulô & $\begin{array}{l}\text { Sextilha } \\
\text { Moderna }\end{array}$ & $\begin{array}{l}\text { Variante } \\
\text { matuta }\end{array}$ \\
\hline 12 & A Garça e o Urubu & Ispinho e Fulô & Quartetos & $\begin{array}{l}\text { Norma } \\
\text { padrão }\end{array}$ \\
\hline 13 & A Ligeira do ão & $\begin{array}{l}\text { Melhores Poemas / } \\
\text { Balceiro } 2\end{array}$ & Quartetos & $\begin{array}{l}\text { Norma } \\
\text { padrão }\end{array}$ \\
\hline 14 & A Mãe e a Filha & Aqui tem coisa & $\begin{array}{l}\text { Mistas: Sex. e } \\
\text { Déc. }\end{array}$ & $\begin{array}{l}\text { Variante } \\
\text { matuta }\end{array}$ \\
\hline 15 & A menina e a Cajazeira ${ }^{69}$ & $\begin{array}{l}\text { Inspiração } \\
\text { nordestina / Cante }\end{array}$ & $\begin{array}{l}\text { Décimas - Tipo } \\
\text { C }\end{array}$ & $\begin{array}{l}\text { Variante } \\
\text { matuta }\end{array}$ \\
\hline
\end{tabular}

66 Trata-se de um aproveitamento do trabalho realizado por Cláudio Andrade, em sua tese de Doutorado, Aspectos e impasses da poesia de Patativa do Assaré, acrescentando a coluna referente ao tipo de linguagem, alguns poemas e ainda as divergências de títulos destes.

67 "Filosofia de um trovador sertanejo". In: Cante lá que eu canto cá (1978 e 2014).

68 “A foguêra de São João". In: Cante lá que eu canto cá (1978 e 2014) e Melhores poemas (2006).

69 “A menina e a cajazêra”. In: Cante lá que eu canto cá (1978 e 2014). 


\begin{tabular}{|c|c|c|c|c|}
\hline & & lá que eu canto cá & & \\
\hline 16 & A Menina Mendiga & $\begin{array}{l}\text { Inspiração } \\
\text { nordestina / Cante } \\
\text { lá que eu canto cá }\end{array}$ & Soneto & $\begin{array}{l}\text { Norma } \\
\text { padrão }\end{array}$ \\
\hline 17 & À Meretriz & $\begin{array}{l}\text { Balceiro / } \\
\text { Melhores Poemas }\end{array}$ & Soneto & $\begin{array}{l}\text { Norma } \\
\text { padrão }\end{array}$ \\
\hline 18 & A Minha Cinza & $\begin{array}{l}\text { Balceiro / } \\
\text { Melhores Poemas }\end{array}$ & Soneto & $\begin{array}{l}\text { Norma } \\
\text { padrão }\end{array}$ \\
\hline 19 & A Morte & $\begin{array}{l}\text { Inspiração } \\
\text { nordestina }\end{array}$ & Soneto & $\begin{array}{l}\text { Norma } \\
\text { padrão }\end{array}$ \\
\hline 20 & A Morte - Estrambote & Melhores Poemas & $\begin{array}{l}\text { Mista: soneto e } \\
\text { sextilha }\end{array}$ & $\begin{array}{l}\text { Norma } \\
\text { padrão }\end{array}$ \\
\hline 21 & A Morte de Artur Pereira & Cordéis & Sextilha Cordel & $\begin{array}{l}\text { Norma } \\
\text { padrão }\end{array}$ \\
\hline 22 & A Morte de Nanã & $\begin{array}{l}\text { Cante lá que eu } \\
\text { canto cá / Melhores } \\
\text { Poemas / Novos } \\
\text { poemas } \\
\text { comentados }\end{array}$ & $\begin{array}{l}\text { Décimas - Tipo } \\
\text { A }\end{array}$ & $\begin{array}{l}\text { Variante } \\
\text { matuta }\end{array}$ \\
\hline 23 & A Muié qui mais amei & $\begin{array}{l}\text { Cante lá que eu } \\
\text { canto cá }\end{array}$ & $\begin{array}{l}\text { Décimas - Tipo } \\
\text { A }\end{array}$ & $\begin{array}{l}\text { Variante } \\
\text { matuta }\end{array}$ \\
\hline 24 & A Mulher & $\begin{array}{l}\text { Balceiro / } \\
\text { Melhores Poemas }\end{array}$ & Quartetos & $\begin{array}{l}\text { Norma } \\
\text { padrão }\end{array}$ \\
\hline 25 & A Negra Mariana & Aqui tem coisa & Quartetos & $\begin{array}{l}\text { Norma } \\
\text { padrão }\end{array}$ \\
\hline 26 & A Política & $\begin{array}{l}\text { Inspiração } \\
\text { nordestina }\end{array}$ & $\begin{array}{l}\text { Décimas - Tipo } \\
\text { B }\end{array}$ & $\begin{array}{l}\text { Norma } \\
\text { padrão }\end{array}$ \\
\hline 27 & À Professora Neuma & $\begin{array}{l}\text { Balceiro / } \\
\text { Melhores Poemas }\end{array}$ & Soneto & $\begin{array}{l}\text { Norma } \\
\text { padrão }\end{array}$ \\
\hline 28 & A Realidade da Vida & Ispinho e Fulô & $\begin{array}{l}\text { Décimas - Tipo } \\
\text { A }\end{array}$ & $\begin{array}{l}\text { Variante } \\
\text { matuta }\end{array}$ \\
\hline 29 & A Revolta do Passamento & Aqui tem coisa & Quartetos & $\begin{array}{l}\text { Norma } \\
\text { padrão }\end{array}$ \\
\hline 30 & A Seca & Aqui tem coisa & Quartetos & $\begin{array}{l}\text { Norma } \\
\text { padrão }\end{array}$ \\
\hline 31 & A Sorte de Joli & $\begin{array}{l}\text { Cante lá que eu } \\
\text { canto cá }\end{array}$ & Soneto & $\begin{array}{l}\text { Norma } \\
\text { padrão }\end{array}$ \\
\hline 32 & A Terra é naturá & $\begin{array}{l}\text { Inspiração } \\
\text { nordestina / Cante } \\
\text { lá que eu canto cá / } \\
\text { Aqui tem coisa }\end{array}$ & $\begin{array}{l}\text { Décimas - Tipo } \\
\text { A }\end{array}$ & $\begin{array}{l}\text { Variante } \\
\text { matuta }\end{array}$ \\
\hline 33 & A Terra é Nossa & Ispinho e Fulô & Quartetos & $\begin{array}{l}\text { Norma } \\
\text { padrão }\end{array}$ \\
\hline 34 & A Triste Partida & $\begin{array}{l}\text { Inspiração } \\
\text { nordestina / Cante } \\
\text { lá que eu canto cá/ } \\
\text { Ispinho Fulô / } \\
\text { Melhores Poemas / } \\
\text { Cordel }\end{array}$ & $\begin{array}{l}\text { Sextilhas } \\
\text { compostas }\end{array}$ & $\begin{array}{l}\text { Variante } \\
\text { matuta }\end{array}$ \\
\hline
\end{tabular}




\begin{tabular}{|c|c|c|c|c|}
\hline 35 & A tristeza mais triste & $\begin{array}{l}\text { Inspiração } \\
\text { nordestina }\end{array}$ & $\begin{array}{l}\text { Mistas: Sex. e } \\
\text { quadra }\end{array}$ & $\begin{array}{l}\text { Norma } \\
\text { padrão }\end{array}$ \\
\hline 36 & A Verdade e a Mentira & Ispinho e Fulô & Irregulares & $\begin{array}{l}\text { Variante } \\
\text { matuta }\end{array}$ \\
\hline 37 & A Vida aqui é assim & $\begin{array}{l}\text { Inspiração } \\
\text { nordestina / Cante } \\
\text { lá que eu canto cá }\end{array}$ & $\begin{array}{l}\text { Décimas - Tipo } \\
\text { C }\end{array}$ & $\begin{array}{l}\text { Variante } \\
\text { matuta }\end{array}$ \\
\hline 38 & $\begin{array}{l}\text { A voz do milho } \\
\text { abandonado }\end{array}$ & $\begin{array}{l}\text { Balceiro / } \\
\text { Melhores Poemas }\end{array}$ & Septilhas & $\begin{array}{l}\text { Norma } \\
\text { padrão }\end{array}$ \\
\hline 39 & $\begin{array}{l}\text { ABC do Nordeste } \\
\text { flagelado }\end{array}$ & $\begin{array}{l}\text { Inspiração } \\
\text { nordestina / Cante } \\
\text { lá que eu canto cá / } \\
\text { Aqui tem coisa / } \\
\text { Melhores Poemas / } \\
\text { Cordel }\end{array}$ & $\begin{array}{l}\text { Décimas - Tipo } \\
\text { B }\end{array}$ & $\begin{array}{l}\text { Variante } \\
\text { matuta }\end{array}$ \\
\hline 40 & Açaré $^{70}$ & $\begin{array}{l}\text { Inspiração } \\
\text { nordestina / } \\
\text { Ispinho e Fulô }\end{array}$ & $\begin{array}{l}\text { Décimas - Tipo } \\
\text { A }\end{array}$ & $\begin{array}{l}\text { Variante } \\
\text { matuta }\end{array}$ \\
\hline 41 & Acróstico Espalhafatoso & Balceiro & Soneto & $\begin{array}{l}\text { Norma } \\
\text { padrão }\end{array}$ \\
\hline 42 & Acrósticos & $\begin{array}{l}\text { Inspiração } \\
\text { nordestina }\end{array}$ & Quartetos & $\begin{array}{l}\text { Norma } \\
\text { padrão }\end{array}$ \\
\hline 43 & Adeus à Viola & $\begin{array}{l}\text { Inspiração } \\
\text { nordestina }\end{array}$ & Quartetos & $\begin{array}{l}\text { Norma } \\
\text { padrão }\end{array}$ \\
\hline 44 & Amanhã & $\begin{array}{l}\text { Cante lá que eu } \\
\text { canto cá / Melhores } \\
\text { Poemas }\end{array}$ & Soneto & $\begin{array}{l}\text { Norma } \\
\text { padrão }\end{array}$ \\
\hline 45 & Amor Materno & Aqui tem coisa & $\begin{array}{l}\text { Sextilha } \\
\text { Composta }\end{array}$ & $\begin{array}{l}\text { Norma } \\
\text { padrão }\end{array}$ \\
\hline 46 & Antônio Conselheiro & $\begin{array}{l}\text { Ispinho e Fulô / } \\
\text { Cordel }\end{array}$ & $\begin{array}{l}\text { Décimas - Tipo } \\
\text { A }\end{array}$ & $\begin{array}{l}\text { Norma } \\
\text { padrão }\end{array}$ \\
\hline 47 & $\begin{array}{l}\text { Ao Artista Rolando } \\
\text { Boldrim }\end{array}$ & Aqui tem coisa & $\begin{array}{l}\text { Sextilha } \\
\text { Moderna }\end{array}$ & $\begin{array}{l}\text { Variante } \\
\text { matuta }\end{array}$ \\
\hline 48 & Ao Artista Zenon Barreto & Aqui tem coisa & $\begin{array}{l}\text { Décimas - Tipo } \\
\text { A }\end{array}$ & $\begin{array}{l}\text { Norma } \\
\text { padrão }\end{array}$ \\
\hline 49 & Ao dotô do avião & $\begin{array}{l}\text { Cante lá que eu } \\
\text { canto cá / Melhores } \\
\text { Poemas }\end{array}$ & $\begin{array}{l}\text { Sextilha } \\
\text { Moderna }\end{array}$ & $\begin{array}{l}\text { Variante } \\
\text { matuta }\end{array}$ \\
\hline 50 & Ao leitô & $\begin{array}{l}\text { Inspiração } \\
\text { nordestina }\end{array}$ & Quartetos & $\begin{array}{l}\text { Variante } \\
\text { matuta }\end{array}$ \\
\hline 51 & $\begin{array}{l}\text { Ao locutor da Rádio } \\
\text { Araripe }\end{array}$ & $\begin{array}{l}\text { Cante lá que eu } \\
\text { canto cá }\end{array}$ & Oitavas & $\begin{array}{l}\text { Variante } \\
\text { matuta }\end{array}$ \\
\hline 52 & Ao meu afilhado Cainã & Aqui tem coisa & $\begin{array}{l}\text { Sextilha } \\
\text { Moderna }\end{array}$ & $\begin{array}{l}\text { Norma } \\
\text { padrão }\end{array}$ \\
\hline 53 & Ao Padre Miracapilo & Ispinho e Fulô & Soneto & $\begin{array}{l}\text { Norma } \\
\text { padrão }\end{array}$ \\
\hline 54 & Ao poeta B.C. Neto & Ispinho e Fulô & $\begin{array}{l}\text { Décimas - Tipo } \\
\text { A }\end{array}$ & $\begin{array}{l}\text { Variante } \\
\text { matuta }\end{array}$ \\
\hline
\end{tabular}

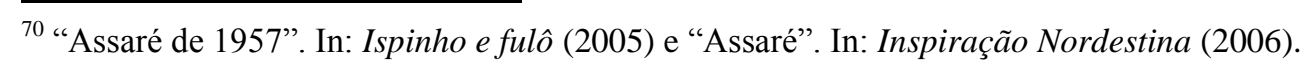




\begin{tabular}{|c|c|c|c|c|}
\hline 55 & Ao Poeta do Sertão & $\begin{array}{l}\text { Ispinho e Fulô / } \\
\text { Inspiração } \\
\text { Nordestina }\end{array}$ & $\begin{array}{l}\text { Sextilha } \\
\text { Moderna }\end{array}$ & $\begin{array}{l}\text { Norma } \\
\text { padrão }\end{array}$ \\
\hline 56 & $\begin{array}{l}\text { Ao poeta João Batista de } \\
\text { Cerqueira }\end{array}$ & $\begin{array}{l}\text { Cante lá que eu } \\
\text { canto cá }\end{array}$ & $\begin{array}{l}\text { Décimas - Tipo } \\
\text { A }\end{array}$ & $\begin{array}{l}\text { Norma } \\
\text { padrão }\end{array}$ \\
\hline 57 & $\begin{array}{l}\text { Ao supervisor Jorge } \\
\text { Édem }\end{array}$ & $\begin{array}{l}\text { Cante lá que eu } \\
\text { canto cá }\end{array}$ & $\begin{array}{l}\text { Sextilha } \\
\text { Moderna }\end{array}$ & $\begin{array}{l}\text { Norma } \\
\text { padrão }\end{array}$ \\
\hline 58 & $\begin{array}{l}\text { Aos filhos e aos netos do } \\
\text { Dr. Arraes de Alencar }\end{array}$ & $\begin{array}{l}\text { Novos poemas } \\
\text { comentados }\end{array}$ & $\begin{array}{l}\text { Décimas - Tipo } \\
\text { A }\end{array}$ & $\begin{array}{l}\text { Norma } \\
\text { padrão }\end{array}$ \\
\hline 59 & Aos Irmãos Aniceto & Ispinho e Fulô & $\begin{array}{l}\text { Décimas - Tipo } \\
\text { A }\end{array}$ & $\begin{array}{l}\text { Variante } \\
\text { matuta }\end{array}$ \\
\hline 60 & Aos Poetas Clássicos & $\begin{array}{l}\text { Cante lá que eu } \\
\text { canto cá }\end{array}$ & $\begin{array}{l}\text { Décimas - Tipo } \\
\text { A }\end{array}$ & $\begin{array}{l}\text { Linguagem } \\
\text { matuta }\end{array}$ \\
\hline 61 & Aos Reis do Baião & Aos Reis do Baião & $\begin{array}{l}\text { Décimas - Tipo } \\
\text { A }\end{array}$ & $\begin{array}{l}\text { Variante } \\
\text { matuta }\end{array}$ \\
\hline 62 & Apelo de um Agricultor & $\begin{array}{l}\text { Cante lá que eu } \\
\text { canto cá }\end{array}$ & $\begin{array}{l}\text { Décimas - Tipo } \\
\text { A }\end{array}$ & $\begin{array}{l}\text { Variante } \\
\text { matuta }\end{array}$ \\
\hline 63 & $\begin{array}{l}\text { Aposentadoria do Mané } \\
\text { do Riachão }\end{array}$ & Aqui tem coisa & $\begin{array}{l}\text { Décimas - Tipo } \\
\text { A }\end{array}$ & $\begin{array}{l}\text { Variante } \\
\text { matuta }\end{array}$ \\
\hline 64 & $\begin{array}{l}\text { Abertura de Novos } \\
\text { Poemas }\end{array}$ & $\begin{array}{l}\text { Novos poemas } \\
\text { comentados }\end{array}$ & $\begin{array}{l}\text { Décimas - Tipo } \\
\text { A }\end{array}$ & $\begin{array}{l}\text { Norma } \\
\text { padrão }\end{array}$ \\
\hline 65 & Aqui tem coisa & Aqui tem coisa & $\begin{array}{l}\text { Décimas - Tipo } \\
\text { A }\end{array}$ & $\begin{array}{l}\text { Norma } \\
\text { padrão }\end{array}$ \\
\hline 66 & $\begin{array}{l}\text { As Façanhas de João } \\
\text { Mole }\end{array}$ & $\begin{array}{l}\text { Inspiração } \\
\text { nordestina / Cordel }\end{array}$ & $\begin{array}{l}\text { Mistas - sext.e } \\
\text { déc. }\end{array}$ & $\begin{array}{l}\text { Norma } \\
\text { padrão }\end{array}$ \\
\hline 67 & $\begin{array}{l}\text { As narrativas de Zé } \\
\text { Tataíra }\end{array}$ & $\begin{array}{l}\text { Novos poemas } \\
\text { comentados }\end{array}$ & $\begin{array}{l}\text { Décimas - Tipo } \\
\text { A }\end{array}$ & $\begin{array}{l}\text { Variante } \\
\text { matuta }\end{array}$ \\
\hline 68 & As Proezas de Sabina & $\begin{array}{l}\text { Melhores Poemas / } \\
\text { Novos poemas } \\
\text { comentados }\end{array}$ & $\begin{array}{l}\text { Décimas - Tipo } \\
\text { A }\end{array}$ & $\begin{array}{l}\text { Variante } \\
\text { matuta }\end{array}$ \\
\hline 69 & $\begin{array}{l}\text { As Proezas do Padre } \\
\text { Nonato }\end{array}$ & $\begin{array}{l}\text { Inspiração } \\
\text { nordestina }\end{array}$ & $\begin{array}{l}\text { Décimas - Tipo } \\
\text { B }\end{array}$ & $\begin{array}{l}\text { Variante } \\
\text { matuta }\end{array}$ \\
\hline 70 & Assaré e Mossoró & Ispinho e Fulô & $\begin{array}{l}\text { Décimas - Tipo } \\
\text { A }\end{array}$ & $\begin{array}{l}\text { Norma } \\
\text { padrão }\end{array}$ \\
\hline 71 & Autobiografia & Balceiro & $\begin{array}{l}\text { Décimas - Tipo } \\
\text { A }\end{array}$ & $\begin{array}{l}\text { Variante } \\
\text { matuta }\end{array}$ \\
\hline 72 & Ave Noturna & $\begin{array}{l}\text { Cante lá que eu } \\
\text { canto cá / Novos } \\
\text { poemas } \\
\text { comentados }\end{array}$ & Quartetos & $\begin{array}{l}\text { Norma } \\
\text { padrão }\end{array}$ \\
\hline 73 & Baladeira & $\begin{array}{l}\text { Novos poemas } \\
\text { comentados }\end{array}$ & Soneto & $\begin{array}{l}\text { Norma } \\
\text { padrão }\end{array}$ \\
\hline 74 & Barriga Branca & Ispinho e Fulô & Quartetos & $\begin{array}{l}\text { Norma } \\
\text { padrão }\end{array}$ \\
\hline 75 & Bertolino e Zé Tingó $^{71}$ & $\begin{array}{l}\text { Inspiração } \\
\text { nordestina / Aqui } \\
\text { tem coisa }\end{array}$ & $\begin{array}{l}\text { Décimas - Tipo } \\
\text { C }\end{array}$ & $\begin{array}{l}\text { Variante } \\
\text { matuta }\end{array}$ \\
\hline 76 & Bicho da Careca & Balceiro & Irregulares & \\
\hline
\end{tabular}

71 “Bertulino e Zé Tingó”. In: Aqui tem coisa (2012). 


\begin{tabular}{|c|c|c|c|c|}
\hline 77 & Biografia de Sansão & Aqui tem coisa & Septilhas & $\begin{array}{l}\text { Variante } \\
\text { matuta }\end{array}$ \\
\hline 78 & Boa noite, Fortaleza & $\begin{array}{l}\text { Cante lá que eu } \\
\text { canto cá }\end{array}$ & $\begin{array}{l}\text { Décimas - Tipo } \\
\text { A }\end{array}$ & $\begin{array}{l}\text { Variante } \\
\text { matuta }\end{array}$ \\
\hline 79 & Bom dia 93 & Aqui tem coisa & $\begin{array}{l}\text { Décimas - Tipo } \\
\text { A }\end{array}$ & $\begin{array}{l}\text { Norma } \\
\text { padrão }\end{array}$ \\
\hline 80 & $\begin{array}{l}\text { Brasi de cima, Brasi de } \\
\text { baxo }\end{array}$ & $\begin{array}{l}\text { Cante lá que eu } \\
\text { canto cá / Melhores } \\
\text { Poemas }\end{array}$ & $\begin{array}{l}\text { Décimas - Tipo } \\
\text { A }\end{array}$ & $\begin{array}{l}\text { Variante } \\
\text { matuta }\end{array}$ \\
\hline 81 & $\begin{array}{l}\text { Brosogó, Militão e o } \\
\text { Diabo }\end{array}$ & $\begin{array}{l}\text { Ispinho e Fulô / } \\
\text { Melhores Poemas / } \\
\text { Cordel }\end{array}$ & Sextilha Cordel & $\begin{array}{l}\text { Norma } \\
\text { padrão }\end{array}$ \\
\hline 82 & Cabôca de Minha Terra & $\begin{array}{l}\text { Inspiração } \\
\text { nordestina / Cante } \\
\text { lá que eu canto cá }\end{array}$ & $\begin{array}{l}\text { Décimas - Tipo } \\
\text { A }\end{array}$ & $\begin{array}{l}\text { Variante } \\
\text { matuta }\end{array}$ \\
\hline 83 & Caboclo Roceiro & $\begin{array}{l}\text { Cante lá que eu } \\
\text { canto cá / Melhores } \\
\text { Poemas / Novos } \\
\text { poemas } \\
\text { comentados }\end{array}$ & Quartetos & $\begin{array}{l}\text { Norma } \\
\text { padrão }\end{array}$ \\
\hline 84 & Cada um no seu lugar & Aqui tem coisa & Quartetos & $\begin{array}{l}\text { Norma } \\
\text { padrão }\end{array}$ \\
\hline 85 & Cante lá que eu canto cá & $\begin{array}{l}\text { Inspiração } \\
\text { nordestina / Cante } \\
\text { lá que eu canto cá }\end{array}$ & $\begin{array}{l}\text { Décimas - Tipo } \\
\text { A }\end{array}$ & $\begin{array}{l}\text { Variante } \\
\text { matuta }\end{array}$ \\
\hline 86 & $\begin{array}{l}\text { Carta à Doutora } \\
\text { Henriqueta Galeno }\end{array}$ & $\begin{array}{l}\text { Inspiração } \\
\text { nordestina / } \\
\text { Ispinho e Fulô }\end{array}$ & $\begin{array}{l}\text { Sextilha } \\
\text { Moderna }\end{array}$ & $\begin{array}{l}\text { Variante } \\
\text { matuta }\end{array}$ \\
\hline 87 & Carta a Papai Noel & Aqui tem coisa & Oitavas & $\begin{array}{l}\text { Norma } \\
\text { padrão }\end{array}$ \\
\hline 88 & $\begin{array}{l}\text { Carta ao Padre Antônio } \\
\text { Vieira }^{72}\end{array}$ & $\begin{array}{l}\text { Inspiração } \\
\text { nordestina / Cante } \\
\text { lá que eu canto cá }\end{array}$ & $\begin{array}{l}\text { Décimas - Tipo } \\
\text { A }\end{array}$ & $\begin{array}{l}\text { Variante } \\
\text { matuta }\end{array}$ \\
\hline 89 & $\begin{array}{l}\text { Carta ao Senhor Valmir } \\
\text { Farias }\end{array}$ & $\begin{array}{l}\text { Novos poemas } \\
\text { comentados }\end{array}$ & $\begin{array}{l}\text { Sextilha } \\
\text { Moderna }\end{array}$ & $\begin{array}{l}\text { Norma } \\
\text { padrão }\end{array}$ \\
\hline 90 & $\begin{array}{l}\text { Carta do Pe. Antônio } \\
\text { Vieira ao Patativa }\end{array}$ & Ispinho e Fulô & $\begin{array}{l}\text { Décimas - Tipo } \\
\text { A }\end{array}$ & $\begin{array}{l}\text { Norma } \\
\text { padrão }\end{array}$ \\
\hline 91 & $\begin{array}{l}\text { Carta em versos ao } \\
\text { escritor Tomé Cabral } \\
\text { sobre seu livro "Patuá de } \\
\text { recordações" - Assaré, } \\
\text { maio de } 1979\end{array}$ & Cordel & $\begin{array}{l}\text { Sextilha } \\
\text { Moderna }\end{array}$ & $\begin{array}{l}\text { Variante } \\
\text { matuta }\end{array}$ \\
\hline 92 & Carta ou Bilhete & $\begin{array}{l}\text { Balceiro / } \\
\text { Melhores Poemas }\end{array}$ & Quartetos & $\begin{array}{l}\text { Norma } \\
\text { padrão }\end{array}$ \\
\hline 93 & Castigo do Mucuim & Ispinho e Fulô & $\begin{array}{l}\text { Décimas - Tipo } \\
\text { A }\end{array}$ & $\begin{array}{l}\text { Variante } \\
\text { matuta }\end{array}$ \\
\hline 94 & Chico Forte & Ispinho e Fulô & Soneto & $\begin{array}{l}\text { Norma } \\
\text { padrão }\end{array}$ \\
\hline
\end{tabular}

72 “Carta ao escritor Padre Antônio Vieira”. In: Cante lá que eu canto cá (1978 e 2014). 


\begin{tabular}{|c|c|c|c|c|}
\hline 95 & Chiquita e Mãe Veia & $\begin{array}{l}\text { Inspiração } \\
\text { nordestina / Cante } \\
\text { lá que eu canto cá }\end{array}$ & $\begin{array}{l}\text { Décimas - Tipo } \\
\text { C }\end{array}$ & $\begin{array}{l}\text { Variante } \\
\text { matuta }\end{array}$ \\
\hline 96 & Ciúme & Melhores Poemas & Soneto & $\begin{array}{l}\text { Norma } \\
\text { padrão }\end{array}$ \\
\hline 97 & Coisas do meu Sertão & $\begin{array}{l}\text { Cante lá que eu } \\
\text { canto cá / Novos } \\
\text { poemas } \\
\text { comentados }\end{array}$ & Irregulares & $\begin{array}{l}\text { Variante } \\
\text { matuta }\end{array}$ \\
\hline 98 & Coisas do Rio de Janêro ${ }^{73}$ & $\begin{array}{l}\text { Inspiração } \\
\text { nordestina / Cante } \\
\text { lá que eu canto cá }\end{array}$ & $\begin{array}{l}\text { Sextilha } \\
\text { Moderna }\end{array}$ & $\begin{array}{l}\text { Variante } \\
\text { matuta }\end{array}$ \\
\hline 99 & Comi Piqui e Sonhei & Aqui tem coisa & $\begin{array}{l}\text { Décimas - Tipo } \\
\text { A }\end{array}$ & $\begin{array}{l}\text { Variante } \\
\text { matuta }\end{array}$ \\
\hline 100 & Como deixei de fumar & Aqui tem coisa & Quartetos & $\begin{array}{l}\text { Norma } \\
\text { padrão }\end{array}$ \\
\hline 101 & Conversa de Matuto & $\begin{array}{l}\text { Cante lá que eu } \\
\text { canto cá / Melhores } \\
\text { Poemas }\end{array}$ & $\begin{array}{l}\text { Décimas - Tipo } \\
\text { B }\end{array}$ & $\begin{array}{l}\text { Variante } \\
\text { matuta }\end{array}$ \\
\hline 102 & Coração Doente & Ispinho e Fulô & $\begin{array}{l}\text { Décimas - Tipo } \\
\text { A }\end{array}$ & $\begin{array}{l}\text { Variante } \\
\text { matuta }\end{array}$ \\
\hline 103 & Cousa Estranha $^{74}$ & $\begin{array}{l}\text { Novos poemas } \\
\text { comentados / } \\
\text { Cante lá que eu } \\
\text { canto cá / Melhores } \\
\text { Poemas }\end{array}$ & Soneto & $\begin{array}{l}\text { Norma } \\
\text { padrão }\end{array}$ \\
\hline 104 & Crime Imperdoável & $\begin{array}{l}\text { Inspiração } \\
\text { nordestina / } \\
\text { Ispinho Fulô / } \\
\text { Cante lá que eu } \\
\text { canto cá }\end{array}$ & Quartetos & $\begin{array}{l}\text { Norma } \\
\text { padrão }\end{array}$ \\
\hline 105 & Crítica Construtiva & $\begin{array}{l}\text { Melhores Poemas / } \\
\text { Balceiro } 2\end{array}$ & Septilhas & $\begin{array}{l}\text { Norma } \\
\text { padrão }\end{array}$ \\
\hline 106 & Curioso e Miudinho & Ispinho e Fulô & Irregulares & $\begin{array}{l}\text { Variante } \\
\text { matuta }\end{array}$ \\
\hline 107 & Desafio malcriado & Ao pé da mesa & $\begin{array}{l}\text { Décimas - Tipo } \\
\text { B }\end{array}$ & $\begin{array}{l}\text { Norma } \\
\text { padrão }\end{array}$ \\
\hline 108 & Desapego & $\begin{array}{l}\text { Inspiração } \\
\text { nordestina }\end{array}$ & Quartetos & $\begin{array}{l}\text { Norma } \\
\text { padrão }\end{array}$ \\
\hline 109 & Desilusão & $\begin{array}{l}\text { Inspiração } \\
\text { nordestina }\end{array}$ & $\begin{array}{l}\text { Sextilha } \\
\text { Composta }\end{array}$ & $\begin{array}{l}\text { Norma } \\
\text { padrão }\end{array}$ \\
\hline 110 & Desilusão & $\begin{array}{l}\text { Ispinho e Fulô / } \\
\text { Cante lá que eu } \\
\text { canto cá }\end{array}$ & Soneto & $\begin{array}{l}\text { Norma } \\
\text { padrão }\end{array}$ \\
\hline 111 & Dia das Mães & $\begin{array}{l}\text { Cante lá que eu } \\
\text { canto cá }\end{array}$ & Soneto & $\begin{array}{l}\text { Norma } \\
\text { padrão }\end{array}$ \\
\hline 112 & Dia Nacional da Poesia & Melhores poemas / & Oitavas & Norma \\
\hline
\end{tabular}

73 “Coisas do Rio de Janeiro". In: Cante lá que eu canto cá (1978 e 2014).

74 “Coisa estranha”. In: Melhores poemas (2006). 


\begin{tabular}{|c|c|c|c|c|}
\hline & & Balceiro 2 & & padrão \\
\hline 113 & Dois Anjo & Ispinho e Fulô & $\begin{array}{l}\text { Décimas - Tipo } \\
\text { A }\end{array}$ & $\begin{array}{l}\text { Variante } \\
\text { matuta }\end{array}$ \\
\hline 114 & Dois Quadros & $\begin{array}{l}\text { Cante lá que eu } \\
\text { canto cá / Aqui tem } \\
\text { coisa }\end{array}$ & Quartetos & $\begin{array}{l}\text { Norma } \\
\text { padrão }\end{array}$ \\
\hline 115 & Doutor Honoris Causa & $\begin{array}{l}\text { Melhores Poemas / } \\
\text { Balceiro } 2\end{array}$ & $\begin{array}{l}\text { Sextilha } \\
\text { Moderna }\end{array}$ & $\begin{array}{l}\text { Norma } \\
\text { padrão }\end{array}$ \\
\hline 116 & É coisa do meu sertão & $\begin{array}{l}\text { Cante lá que eu } \\
\text { canto cá }\end{array}$ & $\begin{array}{l}\text { Décimas - Tipo } \\
\text { B }\end{array}$ & $\begin{array}{l}\text { Variante } \\
\text { matuta }\end{array}$ \\
\hline 117 & $\begin{array}{l}\text { É preciso saber compor } \\
\text { soneto }\end{array}$ & $\begin{array}{l}\text { Melhores Poemas / } \\
\text { Ao pé da mesa }\end{array}$ & Soneto & $\begin{array}{l}\text { Norma } \\
\text { padrão }\end{array}$ \\
\hline 118 & Egoísmo & Ispinho e Fulô & $\begin{array}{l}\text { Décimas - Tipo } \\
\text { A }\end{array}$ & $\begin{array}{l}\text { Norma } \\
\text { padrão }\end{array}$ \\
\hline 119 & Ele e ela & $\begin{array}{l}\text { Novos poemas } \\
\text { comentados / } \\
\text { Ispinho e Fulô }\end{array}$ & Soneto & $\begin{array}{l}\text { Norma } \\
\text { padrão }\end{array}$ \\
\hline 120 & $\begin{array}{l}\text { Emigrante Nordestino no } \\
\text { Sul do País } 75\end{array}$ & $\begin{array}{l}\text { Cante lá que eu } \\
\text { canto cá / Cordel }\end{array}$ & $\begin{array}{l}\text { Décimas - Tipo } \\
\text { A }\end{array}$ & $\begin{array}{l}\text { Norma } \\
\text { padrão }\end{array}$ \\
\hline 121 & $\begin{array}{l}\text { Encontro de Patativa do } \\
\text { Assaré com a alma de Zé } \\
\text { Limeira o poeta do } \\
\text { absurdo }\end{array}$ & $\begin{array}{l}\text { Aqui tem coisa / } \\
\text { Cordel }\end{array}$ & $\begin{array}{l}\text { Décimas - Tipo } \\
\text { B }\end{array}$ & $\begin{array}{l}\text { Variante } \\
\text { matuta }\end{array}$ \\
\hline 122 & Engano & $\begin{array}{l}\text { Inspiração } \\
\text { nordestina }\end{array}$ & Soneto & $\begin{array}{l}\text { Norma } \\
\text { padrão }\end{array}$ \\
\hline 123 & $\begin{array}{l}\text { Esta terra parece um } \\
\text { paraíso }\end{array}$ & $\begin{array}{l}\text { Melhores Poemas / } \\
\text { Ao pé da mesa }\end{array}$ & Soneto & $\begin{array}{l}\text { Norma } \\
\text { padrão }\end{array}$ \\
\hline 124 & Eu e a Pitombêra & Ispinho e Fulô & $\begin{array}{l}\text { Décimas - Tipo } \\
\text { A }\end{array}$ & $\begin{array}{l}\text { Variante } \\
\text { matuta }\end{array}$ \\
\hline 125 & Eu e meu Campina & Ispinho e Fulô & $\begin{array}{l}\text { Décimas - Tipo } \\
\text { A }\end{array}$ & $\begin{array}{l}\text { Norma } \\
\text { padrão }\end{array}$ \\
\hline 126 & Eu e o Padre Nonato & Ispinho e Fulô & $\begin{array}{l}\text { Sextilha } \\
\text { Moderna }\end{array}$ & $\begin{array}{l}\text { Norma } \\
\text { padrão }\end{array}$ \\
\hline 127 & Eu e o Sertão & $\begin{array}{l}\text { Cante lá que eu } \\
\text { canto cá }\end{array}$ & $\begin{array}{l}\text { Décimas - Tipo } \\
\text { A }\end{array}$ & $\begin{array}{l}\text { Variante } \\
\text { matuta }\end{array}$ \\
\hline 128 & Eu quero & $\begin{array}{l}\text { Cante lá que eu } \\
\text { canto cá }\end{array}$ & $\begin{array}{l}\text { Sextilha } \\
\text { Moderna }\end{array}$ & $\begin{array}{l}\text { Norma } \\
\text { padrão }\end{array}$ \\
\hline 129 & Eu sou do campo & $\begin{array}{l}\text { Balceiro / } \\
\text { Melhores poemas }\end{array}$ & Quartetos & $\begin{array}{l}\text { Norma } \\
\text { padrão }\end{array}$ \\
\hline 130 & Felicidade & Aqui tem coisa & Quartetos & $\begin{array}{l}\text { Norma } \\
\text { padrão }\end{array}$ \\
\hline 131 & Filho de Gato é Gatinho & Ispinho e Fulô & Quartetos & $\begin{array}{l}\text { Norma } \\
\text { padrão }\end{array}$ \\
\hline 132 & $\begin{array}{l}\text { Filosofia de um trovador } \\
\text { sertanejo }\end{array}$ & $\begin{array}{l}\text { Cante lá que eu } \\
\text { canto cá }\end{array}$ & $\begin{array}{l}\text { Décimas - Tipo } \\
\text { B }\end{array}$ & $\begin{array}{l}\text { Variante } \\
\text { matuta }\end{array}$ \\
\hline 133 & Flores murchas & $\begin{array}{l}\text { Novos poemas } \\
\text { comentados / }\end{array}$ & Soneto & $\begin{array}{l}\text { Norma } \\
\text { padrão }\end{array}$ \\
\hline
\end{tabular}

75 “Emigração". In: Cordéis (2012).

76 “A peleja de Patativa do Assaré com Zé Limeira”. In: Cordéis (2012). 


\begin{tabular}{|c|c|c|c|c|}
\hline & & $\begin{array}{l}\text { Cante lá que eu } \\
\text { canto cá }\end{array}$ & & \\
\hline 134 & Fonte Patativana & $\begin{array}{l}\text { Melhores Poemas / } \\
\text { Balceiro } 2\end{array}$ & $\begin{array}{l}\text { Décimas - Tipo } \\
\text { B }\end{array}$ & $\begin{array}{l}\text { Norma } \\
\text { padrão }\end{array}$ \\
\hline 135 & Franga de Bêia & $\begin{array}{l}\text { Novos poemas } \\
\text { comentados }\end{array}$ & $\begin{array}{l}\text { Décimas - Tipo } \\
\text { B }\end{array}$ & $\begin{array}{l}\text { Norma } \\
\text { padrão }\end{array}$ \\
\hline 136 & Fuga de Vênus & $\begin{array}{l}\text { Balceiro / } \\
\text { Melhores Poemas }\end{array}$ & Soneto & $\begin{array}{l}\text { Norma } \\
\text { padrão }\end{array}$ \\
\hline 137 & Garoto Inteligente & $\begin{array}{l}\text { Balceiro / } \\
\text { Melhores Poemas }\end{array}$ & Quartetos & $\begin{array}{l}\text { Norma } \\
\text { padrão }\end{array}$ \\
\hline 138 & Gratidão & $\begin{array}{l}\text { Inspiração } \\
\text { nordestina }\end{array}$ & Oitavas & $\begin{array}{l}\text { Norma } \\
\text { padrão }\end{array}$ \\
\hline 139 & Gratidão & Ispinho e Fulô & Soneto & $\begin{array}{l}\text { Norma } \\
\text { padrão }\end{array}$ \\
\hline 140 & Gratidão & $\begin{array}{l}\text { Novos poemas } \\
\text { comentados }\end{array}$ & $\begin{array}{l}\text { Décimas - Tipo } \\
\text { A }\end{array}$ & $\begin{array}{l}\text { Variante } \\
\text { matuta }\end{array}$ \\
\hline 140 & Herança & $\begin{array}{l}\text { Balceiro / } \\
\text { Melhores Poemas }\end{array}$ & Soneto & $\begin{array}{l}\text { Norma } \\
\text { padrão }\end{array}$ \\
\hline 141 & $\begin{array}{l}\text { História de Abílio e seu } \\
\text { cachorro Jupi }\end{array}$ & Cordel & Sextilha Cordel & $\begin{array}{l}\text { Norma } \\
\text { padrão }\end{array}$ \\
\hline 142 & $\begin{array}{l}\text { História de Aladim e a } \\
\text { Lâmpada Maravilhosa }\end{array}$ & Cordel & Sextilha Cordel & $\begin{array}{l}\text { Norma } \\
\text { padrão }\end{array}$ \\
\hline 143 & História de uma cruz & $\begin{array}{l}\text { Novos poemas } \\
\text { comentados / } \\
\text { Cante lá que eu } \\
\text { canto cá / Melhores } \\
\text { Poemas } \\
\end{array}$ & $\begin{array}{l}\text { Sextilha } \\
\text { Composta }\end{array}$ & $\begin{array}{l}\text { Variante } \\
\text { matuta }\end{array}$ \\
\hline 144 & $\begin{array}{l}\text { Homenagem ao escritor } \\
\text { Padre Antonio Vieira nos } \\
\text { seus setenta anos }\end{array}$ & Aqui tem coisa & $\begin{array}{l}\text { Décimas - Tipo } \\
\text { A }\end{array}$ & $\begin{array}{l}\text { Norma } \\
\text { padrão }\end{array}$ \\
\hline 145 & Ilustríssimo Senhô Doutô & $\begin{array}{l}\text { Inspiração } \\
\text { nordestina / Aqui } \\
\text { tem coisa }\end{array}$ & $\begin{array}{l}\text { Décimas - Tipo } \\
\text { A }\end{array}$ & $\begin{array}{l}\text { Variante } \\
\text { matuta }\end{array}$ \\
\hline 146 & $\begin{array}{l}\text { Ilustríssimo Sr. Elóia } \\
\text { Teles }\end{array}$ & Aqui tem coisa & Mistas & $\begin{array}{l}\text { Variante } \\
\text { matuta }\end{array}$ \\
\hline 147 & Ingém de ferro & $\begin{array}{l}\text { Inspiração } \\
\text { nordestina / Cante } \\
\text { lá que eu canto cá }\end{array}$ & $\begin{array}{l}\text { Décimas - Tipo } \\
\text { A }\end{array}$ & $\begin{array}{l}\text { Variante } \\
\text { matuta }\end{array}$ \\
\hline 148 & Ingratidão & $\begin{array}{l}\text { Cante lá que eu } \\
\text { canto cá }\end{array}$ & $\begin{array}{l}\text { Décimas - Tipo } \\
\text { A }\end{array}$ & $\begin{array}{l}\text { Variante } \\
\text { matuta }\end{array}$ \\
\hline 149 & Ingratidão & $\begin{array}{l}\text { Aqui tem coisa / } \\
\text { Melhores Poemas }\end{array}$ & Soneto & $\begin{array}{l}\text { Norma } \\
\text { padrão }\end{array}$ \\
\hline 150 & Injustiça & Ispinho e Fulô & $\begin{array}{l}\text { Sextilha } \\
\text { Composta }\end{array}$ & $\begin{array}{l}\text { Norma } \\
\text { padrão }\end{array}$ \\
\hline 151 & Inleição Direta & Ispinho e Fulô & $\begin{array}{l}\text { Décimas - Tipo } \\
\text { A }\end{array}$ & $\begin{array}{l}\text { Variante } \\
\text { matuta }\end{array}$ \\
\hline 152 & $\begin{array}{l}\text { Invocação a Leonardo } \\
\text { Mota }\end{array}$ & $\begin{array}{l}\text { Inspiração } \\
\text { nordestina }\end{array}$ & Quartetos & $\begin{array}{l}\text { Norma } \\
\text { padrão }\end{array}$ \\
\hline 153 & Ispinho e Fulô & Ispinho e Fulô & Décimas - Tipo & Variante \\
\hline
\end{tabular}




\begin{tabular}{|c|c|c|c|c|}
\hline & & & A & matuta \\
\hline 154 & Juazeiro e Petrolina & Ispinho e Fulô & $\begin{array}{l}\text { Décimas - Tipo } \\
\text { A }\end{array}$ & $\begin{array}{l}\text { Variante } \\
\text { matuta }\end{array}$ \\
\hline 155 & Justiça de Zé Caçado & Aqui tem coisa & $\begin{array}{l}\text { Décimas - Tipo } \\
\text { A }\end{array}$ & $\begin{array}{l}\text { Variante } \\
\text { matuta }\end{array}$ \\
\hline 156 & Ladrão de Roça & Aqui tem coisa & Quartetos & $\begin{array}{l}\text { Norma } \\
\text { padrão }\end{array}$ \\
\hline 157 & $\begin{array}{l}\text { Lagartixas verdinhas pelo } \\
\text { chão }\end{array}$ & $\begin{array}{l}\text { Melhores Poemas / } \\
\text { Balceiro } 2\end{array}$ & $\begin{array}{l}\text { Décimas - Tipo } \\
\text { B }\end{array}$ & $\begin{array}{l}\text { Norma } \\
\text { padrão }\end{array}$ \\
\hline 158 & $\begin{array}{l}\text { Lamentos de um } \\
\text { nordestino }\end{array}$ & $\begin{array}{l}\text { Inspiração } \\
\text { nordestina }\end{array}$ & $\begin{array}{l}\text { Mistas: sext. } \\
\text { Terceto }\end{array}$ & $\begin{array}{l}\text { Norma } \\
\text { padrão }\end{array}$ \\
\hline 159 & Lero Lero & Aqui tem coisa & Quartetos & $\begin{array}{l}\text { Norma } \\
\text { padrão }\end{array}$ \\
\hline 160 & Lição de um pai & Balceiro 2 & Soneto & $\begin{array}{l}\text { Norma } \\
\text { padrão }\end{array}$ \\
\hline 161 & Lição do Pinto & $\begin{array}{l}\text { Ispinho e Fulô / } \\
\text { Aqui tem coisa }\end{array}$ & $\begin{array}{l}\text { Sextilha } \\
\text { Moderna }\end{array}$ & $\begin{array}{l}\text { Norma } \\
\text { padrão }\end{array}$ \\
\hline 162 & Lições de um cego & Aqui tem coisa & $\begin{array}{l}\text { Décimas - Tipo } \\
\text { A }\end{array}$ & $\begin{array}{l}\text { Norma } \\
\text { padrão }\end{array}$ \\
\hline 163 & Língua Ferina & Ispinho e Fulô & Quartetos & $\begin{array}{l}\text { Norma } \\
\text { padrão }\end{array}$ \\
\hline 164 & Linguage dos Óio & Ispinho e Fulô & $\begin{array}{l}\text { Décimas - Tipo } \\
\text { A }\end{array}$ & $\begin{array}{l}\text { Variante } \\
\text { matuta }\end{array}$ \\
\hline 165 & Luis de Camões & $\begin{array}{l}\text { Cante lá que eu } \\
\text { canto cá }\end{array}$ & Oitavas & $\begin{array}{l}\text { Norma } \\
\text { padrão }\end{array}$ \\
\hline 166 & Mãe de Verdade & Ispinho e Fulô & $\begin{array}{l}\text { Décimas - Tipo } \\
\text { A }\end{array}$ & $\begin{array}{l}\text { Variante } \\
\text { matuta }\end{array}$ \\
\hline 167 & Mãe Preta & $\begin{array}{l}\text { Cante lá que eu } \\
\text { canto cá / Melhores } \\
\text { Poemas }\end{array}$ & $\begin{array}{l}\text { Décimas - Tipo } \\
\text { A }\end{array}$ & $\begin{array}{l}\text { Variante } \\
\text { matuta }\end{array}$ \\
\hline 168 & Maió Decepção & $\begin{array}{l}\text { Cante lá que eu } \\
\text { canto cá / Melhores } \\
\text { Poemas / Novos } \\
\text { poemas } \\
\text { comentados }\end{array}$ & $\begin{array}{l}\text { Décimas - Tipo } \\
\text { A }\end{array}$ & $\begin{array}{l}\text { Variante } \\
\text { matuta }\end{array}$ \\
\hline 169 & Mal de amor & $\begin{array}{l}\text { Cante lá que eu } \\
\text { canto cá }\end{array}$ & Soneto & $\begin{array}{l}\text { Norma } \\
\text { padrão }\end{array}$ \\
\hline 170 & Mané Besta & Aqui tem coisa & $\begin{array}{l}\text { Décimas - Tipo } \\
\text { A }\end{array}$ & $\begin{array}{l}\text { Variante } \\
\text { matuta }\end{array}$ \\
\hline 171 & Maria de Todo Jeito & $\begin{array}{l}\text { Cante lá que eu } \\
\text { canto cá / Melhores } \\
\text { Poemas }\end{array}$ & $\begin{array}{l}\text { Décimas - Tipo } \\
\text { A }\end{array}$ & $\begin{array}{l}\text { Variante } \\
\text { matuta }\end{array}$ \\
\hline 172 & Maria Gulora & $\begin{array}{l}\text { Inspiração } \\
\text { nordestina }\end{array}$ & $\begin{array}{l}\text { Sextilha } \\
\text { Moderna }\end{array}$ & $\begin{array}{l}\text { Variante } \\
\text { matuta }\end{array}$ \\
\hline 173 & Maria Tetê & $\begin{array}{l}\text { Cante lá que eu } \\
\text { canto cá / Melhores } \\
\text { Poemas }\end{array}$ & $\begin{array}{l}\text { Décimas - Tipo } \\
\text { A }\end{array}$ & $\begin{array}{l}\text { Variante } \\
\text { matuta }\end{array}$ \\
\hline 174 & Mello e Meladeira & Aqui tem coisa & $\begin{array}{l}\text { Décimas - Tipo } \\
\text { A }\end{array}$ & $\begin{array}{l}\text { Norma } \\
\text { padrão }\end{array}$ \\
\hline
\end{tabular}




\begin{tabular}{|c|c|c|c|c|}
\hline 175 & Menino de rua & Aqui tem coisa & $\begin{array}{l}\text { Sextilha } \\
\text { Composta }\end{array}$ & $\begin{array}{l}\text { Norma } \\
\text { padrão }\end{array}$ \\
\hline 176 & $\begin{array}{l}\text { Meu avô tinha razão e a } \\
\text { justiça tá errada }\end{array}$ & $\begin{array}{l}\text { Ispinho e Fulô / } \\
\text { Aqui tem coisa }\end{array}$ & $\begin{array}{l}\text { Sextilha } \\
\text { Moderna }\end{array}$ & $\begin{array}{l}\text { Variante } \\
\text { matuta }\end{array}$ \\
\hline 177 & Meu caro jumento & $\begin{array}{l}\text { Inspiração } \\
\text { nordestina / Cante } \\
\text { lá que eu canto cá }\end{array}$ & $\begin{array}{l}\text { Décimas - Tipo } \\
\text { A }\end{array}$ & $\begin{array}{l}\text { Variante } \\
\text { matuta }\end{array}$ \\
\hline 178 & $\begin{array}{l}\text { Meu castigo - Ao meu } \\
\text { neto Expedito }\end{array}$ & $\begin{array}{l}\text { Cante lá que eu } \\
\text { canto cá / Melhores } \\
\text { Poemas }\end{array}$ & Oitavas & $\begin{array}{l}\text { Norma } \\
\text { padrão }\end{array}$ \\
\hline 179 & Meu Palitó & $\begin{array}{l}\text { Inspiração } \\
\text { nordestina }\end{array}$ & $\begin{array}{l}\text { Décimas - Tipo } \\
\text { B }\end{array}$ & $\begin{array}{l}\text { Norma } \\
\text { padrão }\end{array}$ \\
\hline 180 & Meu Passarinho & Ispinho e Fulô & Quartetos & $\begin{array}{l}\text { Norma } \\
\text { padrão }\end{array}$ \\
\hline 181 & Meu Premero Amô & $\begin{array}{l}\text { Inspiração } \\
\text { nordestina / Aqui } \\
\text { tem coisa }\end{array}$ & Oitavas & $\begin{array}{l}\text { Variante } \\
\text { matuta }\end{array}$ \\
\hline 182 & Meu Protesto & $\begin{array}{l}\text { Cante lá que eu } \\
\text { canto cá }\end{array}$ & $\begin{array}{l}\text { Décimas - Tipo } \\
\text { A }\end{array}$ & $\begin{array}{l}\text { Variante } \\
\text { matuta }\end{array}$ \\
\hline 183 & Meu recado a São Pedro & $\begin{array}{l}\text { Balceiro / } \\
\text { Melhores Poemas }\end{array}$ & $\begin{array}{l}\text { Décimas - Tipo } \\
\text { B }\end{array}$ & $\begin{array}{l}\text { Norma } \\
\text { padrão }\end{array}$ \\
\hline 184 & Minha Castanhola & $\begin{array}{l}\text { Balceiro / } \\
\text { Melhores Poemas }\end{array}$ & Soneto & $\begin{array}{l}\text { Norma } \\
\text { padrão }\end{array}$ \\
\hline 185 & $\begin{array}{l}\text { Minha Idade e Minha } \\
\text { Poesia }\end{array}$ & $\begin{array}{l}\text { Melhores Poemas / } \\
\text { Balceiro } 2\end{array}$ & $\begin{array}{l}\text { Décimas - Tipo } \\
\text { A }\end{array}$ & $\begin{array}{l}\text { Norma } \\
\text { padrão }\end{array}$ \\
\hline 186 & $\begin{array}{l}\text { Minha Impressão sobre o } \\
\text { Trem de Ferro }\end{array}$ & Aqui tem coisa & Quartetos & $\begin{array}{l}\text { Variante } \\
\text { matuta }\end{array}$ \\
\hline 187 & Minha Reza & $\begin{array}{l}\text { Novos poemas } \\
\text { comentados / } \\
\text { Melhores Poemas }\end{array}$ & $\begin{array}{l}\text { Décimas - Tipo } \\
\text { A }\end{array}$ & $\begin{array}{l}\text { Norma } \\
\text { padrão }\end{array}$ \\
\hline 188 & Minha Serra & $\begin{array}{l}\text { Inspiração } \\
\text { nordestina / Cante } \\
\text { lá que eu canto cá }\end{array}$ & Soneto & $\begin{array}{l}\text { Norma } \\
\text { padrão }\end{array}$ \\
\hline 189 & Minha Sodade & $\begin{array}{l}\text { Inspiração } \\
\text { nordestina / Cante } \\
\text { lá que eu canto cá }\end{array}$ & $\begin{array}{l}\text { Décimas - Tipo } \\
\text { A }\end{array}$ & $\begin{array}{l}\text { Variante } \\
\text { matuta }\end{array}$ \\
\hline 190 & Minha Vingança & Aqui tem coisa & $\begin{array}{l}\text { Décimas - Tipo } \\
\text { A }\end{array}$ & $\begin{array}{l}\text { Variante } \\
\text { matuta }\end{array}$ \\
\hline 191 & Minha Viola & $\begin{array}{l}\text { Cante lá que eu } \\
\text { canto cá / Melhores } \\
\text { Poemas / Novos } \\
\text { poemas } \\
\text { comentados }\end{array}$ & Oitavas & $\begin{array}{l}\text { Norma } \\
\text { padrão }\end{array}$ \\
\hline 192 & Minhas Filhas & $\begin{array}{l}\text { Balceiro / Aqui } \\
\text { tem coisa / } \\
\text { Melhores Poemas }\end{array}$ & Quartetos & $\begin{array}{l}\text { Norma } \\
\text { padrão }\end{array}$ \\
\hline 193 & Mini-saia & $\begin{array}{l}\text { Novos poemas } \\
\text { comentados }\end{array}$ & Quartetos & $\begin{array}{l}\text { Norma } \\
\text { padrão }\end{array}$ \\
\hline 194 & Morrer sem morrer & Melhores Poemas / & Décima - Tipo & Norma \\
\hline
\end{tabular}




\begin{tabular}{|c|c|c|c|c|}
\hline & deveras & Balceiro 2 & A & padrão \\
\hline 195 & $\begin{array}{l}\text { Mote: O título sem retrato } \\
\text { é uma tapeação }\end{array}$ & $\begin{array}{l}\text { Inspiração } \\
\text { nordestina }\end{array}$ & Décima - Tipo B & $\begin{array}{l}\text { Norma } \\
\text { padrão }\end{array}$ \\
\hline 196 & $\begin{array}{l}\text { Mote: Quem quiser ser } \\
\text { meu amigo, não fale mal } \\
\text { de Assaré }\end{array}$ & $\begin{array}{l}\text { Inspiração } \\
\text { nordestina }\end{array}$ & Décima - Tipo B & $\begin{array}{l}\text { Norma } \\
\text { padrão }\end{array}$ \\
\hline 197 & $\begin{array}{l}\text { Mote: Uma mulher } \\
\text { ciumenta }\end{array}$ & $\begin{array}{l}\text { Inspiração } \\
\text { nordestina }\end{array}$ & Décima - Tipo B & $\begin{array}{l}\text { Norma } \\
\text { padrão }\end{array}$ \\
\hline 198 & $\begin{array}{l}\text { Mote: Com o grito do } \\
\text { dinheiro, a justiça não se } \\
\text { apruma }\end{array}$ & $\begin{array}{l}\text { Inspiração } \\
\text { nordestina / Cante } \\
\text { lá que eu canto cá / } \\
\text { Melhores Poemas }\end{array}$ & Décima - Tipo B & $\begin{array}{l}\text { Norma } \\
\text { padrão }\end{array}$ \\
\hline 199 & $\begin{array}{l}\text { Mote: No terror da } \\
\text { tempestade, geme o mar e } \\
\text { treme a terra }\end{array}$ & $\begin{array}{l}\text { Inspiração } \\
\text { nordestina }\end{array}$ & Décima - Tipo B & $\begin{array}{l}\text { Norma } \\
\text { padrão }\end{array}$ \\
\hline 200 & $\begin{array}{l}\text { Mote: O café da Dona } \\
\text { Santa é o melhor do } \\
\text { mercado }\end{array}$ & $\begin{array}{l}\text { Inspiração } \\
\text { nordestina }\end{array}$ & Décima - Tipo B & $\begin{array}{l}\text { Norma } \\
\text { padrão }\end{array}$ \\
\hline 201 & $\begin{array}{l}\text { Mote: A mulher do } \\
\text { cachaceiro, só sonha com } \\
\text { palhaçada }\end{array}$ & $\begin{array}{l}\text { Inspiração } \\
\text { nordestina }\end{array}$ & Décima - Tipo B & $\begin{array}{l}\text { Norma } \\
\text { padrão }\end{array}$ \\
\hline 202 & $\begin{array}{l}\text { Mote: Coronel, tenha } \\
\text { cuidado, que o } \\
\text { comunismo aí vem }\end{array}$ & $\begin{array}{l}\text { Inspiração } \\
\text { nordestina / } \\
\text { Ispinho e Fulô }\end{array}$ & Décima - Tipo B & $\begin{array}{l}\text { Norma } \\
\text { padrão }\end{array}$ \\
\hline 203 & $\begin{array}{l}\text { Mote: Só desgraça traz a } \\
\text { guerra, defendamos, pois, } \\
\text { a paz }\end{array}$ & $\begin{array}{l}\text { Inspiração } \\
\text { nordestina / Cante } \\
\text { lá que eu canto cá / } \\
\text { Melhores Poemas }\end{array}$ & Décima - Tipo B & $\begin{array}{l}\text { Norma } \\
\text { padrão }\end{array}$ \\
\hline 204 & $\begin{array}{l}\text { Mote: Quem persevera no } \\
\text { bem, trilha o caminho da } \\
\text { glória }\end{array}$ & $\begin{array}{l}\text { Inspiração } \\
\text { nordestina }\end{array}$ & Décima - Tipo B & $\begin{array}{l}\text { Norma } \\
\text { padrão }\end{array}$ \\
\hline 205 & $\begin{array}{l}\text { Mote: Refúgio dos } \\
\text { pecadores }\end{array}$ & $\begin{array}{l}\text { Inspiração } \\
\text { nordestina }\end{array}$ & Décima - Tipo B & $\begin{array}{l}\text { Norma } \\
\text { padrão }\end{array}$ \\
\hline 206 & $\begin{array}{l}\text { Mote: Viva o povo } \\
\text { brasileiro }\end{array}$ & Aqui tem coisa & Décima - Tipo B & $\begin{array}{l}\text { Norma } \\
\text { padrão }\end{array}$ \\
\hline 207 & $\begin{array}{l}\text { Mote: Caía de gota em } \\
\text { gota, sumia de pingo em } \\
\text { pingo }\end{array}$ & Melhores Poemas & Décima - Tipo B & $\begin{array}{l}\text { Norma } \\
\text { padrão }\end{array}$ \\
\hline 208 & $\begin{array}{l}\text { Mote: Borboletas azuis } \\
\text { pela campina faz lembrar } \\
\text { o meu tempo de criança }\end{array}$ & Balceiro 2 & Décima - Tipo B & $\begin{array}{l}\text { Norma } \\
\text { padrão }\end{array}$ \\
\hline 209 & $\begin{array}{l}\text { Mote: Sei que o branco } \\
\text { egoísta se afobou quando } \\
\text { o negro ganhou na loteria }\end{array}$ & Balceiro 2 & Décima - Tipo B & $\begin{array}{l}\text { Norma } \\
\text { padrão }\end{array}$ \\
\hline 210 & $\begin{array}{l}\text { Mote: Vai dançar no } \\
\text { forró da chapadinha }\end{array}$ & Balceiro 2 & Décima - Tipo B & $\begin{array}{l}\text { Norma } \\
\text { padrão }\end{array}$ \\
\hline 211 & $\begin{array}{l}\text { Mote: Para a gente gozar } \\
\text { prazer na vida é preciso } \\
\text { viver com paciência }\end{array}$ & Balceiro 2 & Décima - Tipo B & $\begin{array}{l}\text { Norma } \\
\text { padrão }\end{array}$ \\
\hline
\end{tabular}




\begin{tabular}{|c|c|c|c|c|}
\hline 212 & $\begin{array}{l}\text { Mote: Vi a morte } \\
\text { correndo atrás de mim }\end{array}$ & Balceiro 2 & Décima - Tipo B & $\begin{array}{l}\text { Norma } \\
\text { padrão }\end{array}$ \\
\hline 213 & $\begin{array}{l}\text { Mote: Cada qual faz sua } \\
\text { glosa }\end{array}$ & Balceiro 2 & Décima - Tipo B & $\begin{array}{l}\text { Norma } \\
\text { padrão }\end{array}$ \\
\hline 214 & $\begin{array}{l}\text { Mote: Dentro do meu } \\
\text { coração }\end{array}$ & Balceiro 2 & Décima - Tipo B & $\begin{array}{l}\text { Norma } \\
\text { padrão }\end{array}$ \\
\hline 215 & $\begin{array}{l}\text { Mote: Posso me esquecer } \\
\text { de tudo / mas de glosar eu } \\
\text { duvido }\end{array}$ & Balceiro 2 & Décima - Tipo B & $\begin{array}{l}\text { Norma } \\
\text { padrão }\end{array}$ \\
\hline 216 & $\begin{array}{l}\text { Mote: Os olhos desta } \\
\text { mulata / machucam meu } \\
\text { coração }\end{array}$ & Balceiro 2 & Décima - Tipo B & $\begin{array}{l}\text { Norma } \\
\text { padrão }\end{array}$ \\
\hline 217 & $\begin{array}{l}\text { Mote: Muito triste } \\
\text { chorando sem dinheiro }\end{array}$ & Ao pé da mesa & Décima - Tipo B & $\begin{array}{l}\text { Norma } \\
\text { padrão }\end{array}$ \\
\hline 218 & $\begin{array}{l}\text { Mote: Com o peso da } \\
\text { cruz de muitos anos }\end{array}$ & Ao pé da mesa & Décima - Tipo B & $\begin{array}{l}\text { Norma } \\
\text { padrão }\end{array}$ \\
\hline 219 & $\begin{array}{l}\text { Mote: Reze um terço na } \\
\text { minha sepultura }\end{array}$ & Ao pé da mesa & Décima - Tipo B & $\begin{array}{l}\text { Norma } \\
\text { padrão }\end{array}$ \\
\hline 220 & $\begin{array}{l}\text { Mote: Nas lanternas de } \\
\text { um lindo vagalume }\end{array}$ & Ao pé da mesa & Décima - Tipo B & $\begin{array}{l}\text { Norma } \\
\text { padrão }\end{array}$ \\
\hline 221 & $\begin{array}{l}\text { Mote: Para fazer glosa } \\
\text { bonita / precisa bom } \\
\text { pensamento }\end{array}$ & Ao pé da mesa & Décima - Tipo B & $\begin{array}{l}\text { Norma } \\
\text { padrão }\end{array}$ \\
\hline 222 & $\begin{array}{l}\text { Mote: Para mim não } \\
\text { adianta / falar de quem já } \\
\text { morreu }\end{array}$ & Ao pé da mesa & Décima - Tipo B & $\begin{array}{l}\text { Norma } \\
\text { padrão }\end{array}$ \\
\hline 223 & $\begin{array}{l}\text { Mote: O sol brilha no } \\
\text { infinito / tostando a café } \\
\text { do chão }\end{array}$ & Ao pé da mesa & Décima - Tipo B & $\begin{array}{l}\text { Norma } \\
\text { padrão }\end{array}$ \\
\hline 224 & $\begin{array}{l}\text { Mote: Canta, canta, } \\
\text { passarinho / para ver se a } \\
\text { chuva vem }\end{array}$ & Ao pé da mesa & Décima - Tipo B & $\begin{array}{l}\text { Norma } \\
\text { padrão }\end{array}$ \\
\hline 225 & $\begin{array}{l}\text { Mote: Não me venha para } \\
\text { cá com puxincói }\end{array}$ & Ao pé da mesa & Décima - Tipo B & $\begin{array}{l}\text { Norma } \\
\text { padrão }\end{array}$ \\
\hline 226 & $\begin{array}{l}\text { Mote: Procurando gastar } \\
\text { o que não tinha }\end{array}$ & Ao pé da mesa & Décima - Tipo B & $\begin{array}{l}\text { Norma } \\
\text { padrão }\end{array}$ \\
\hline 227 & $\begin{array}{l}\text { Mote: Carregando um } \\
\text { menino na corcunda }\end{array}$ & Ao pé da mesa & Décima - Tipo B & $\begin{array}{l}\text { Norma } \\
\text { padrão }\end{array}$ \\
\hline 228 & $\begin{array}{l}\text { Mote: Pela estrada da } \\
\text { vida eu vou seguindo / } \\
\text { procurando um amor que } \\
\text { já foi meu }\end{array}$ & Ao pé da mesa & Décima - Tipo B & $\begin{array}{l}\text { Norma } \\
\text { padrão }\end{array}$ \\
\hline 229 & $\begin{array}{l}\text { Mote: Relógio roda o } \\
\text { ponteiro / enquanto eu } \\
\text { faço uma rima }\end{array}$ & Ao pé da mesa & Décima - Tipo B & $\begin{array}{l}\text { Norma } \\
\text { padrão }\end{array}$ \\
\hline 230 & $\begin{array}{l}\text { Mote: Só ficou um } \\
\text { macaquinho / na copa do } \\
\text { catolé }\end{array}$ & Ao pé da mesa & Décima - Tipo B & $\begin{array}{l}\text { Norma } \\
\text { padrão }\end{array}$ \\
\hline 231 & Mote: O sabiá traz & Ao pé da mesa & Décima - Tipo B & Norma \\
\hline
\end{tabular}




\begin{tabular}{|c|c|c|c|c|}
\hline & $\begin{array}{l}\text { saudade / lá da minha } \\
\text { juventude }\end{array}$ & & & padrão \\
\hline 232 & $\begin{array}{l}\text { Mote: Hoje é } 22 \text { do mês / } \\
\text { mas não falta inspiração }\end{array}$ & Ao pé da mesa & Décima - Tipo B & $\begin{array}{l}\text { Norma } \\
\text { padrão }\end{array}$ \\
\hline 233 & $\begin{array}{l}\text { Mote: Vi depois que } \\
\text { arranquei minha botija / } \\
\text { que o potinho era cheio } \\
\text { de besouro }\end{array}$ & Ao pé da mesa & Décima - Tipo B & $\begin{array}{l}\text { Norma } \\
\text { padrão }\end{array}$ \\
\hline 234 & $\begin{array}{l}\text { Mote: O sertão, a viola e } \\
\text { a morena / são as fontes } \\
\text { da minha inspiração }\end{array}$ & Ao pé da mesa & Décima - Tipo B & $\begin{array}{l}\text { Norma } \\
\text { padrão }\end{array}$ \\
\hline 235 & $\begin{array}{l}\text { Mote: Ninguém sabe na } \\
\text { vida o que padece / a } \\
\text { pessoa que vive sem } \\
\text { amor }\end{array}$ & Ao pé da mesa & Décima - Tipo B & $\begin{array}{l}\text { Norma } \\
\text { padrão }\end{array}$ \\
\hline 236 & $\begin{array}{l}\text { Mote: Parabéns, Mariana, } \\
\text { pelo prêmio / que ganhou } \\
\text { no concurso de beleza }\end{array}$ & Ao pé da mesa & Décima - Tipo B & $\begin{array}{l}\text { Norma } \\
\text { padrão }\end{array}$ \\
\hline 237 & $\begin{array}{l}\text { Mote: A floresta é o } \\
\text { castelo / onde a passarada } \\
\text { canta }\end{array}$ & Ao pé da mesa & Décima - Tipo B & $\begin{array}{l}\text { Norma } \\
\text { padrão }\end{array}$ \\
\hline 238 & $\begin{array}{l}\text { Mote: A felicidade existe } \\
\text { / no peito de cada um }\end{array}$ & Ao pé da mesa & Décima - Tipo B & $\begin{array}{l}\text { Norma } \\
\text { padrão }\end{array}$ \\
\hline 239 & $\begin{array}{l}\text { Mote: Pelo caminho da } \\
\text { vida / já sei onde vou } \\
\text { chegar }\end{array}$ & Ao pé da mesa & Décima - Tipo B & $\begin{array}{l}\text { Norma } \\
\text { padrão }\end{array}$ \\
\hline 240 & $\begin{array}{l}\text { Mote: As emoções } \\
\text { tomam conta/ do coração } \\
\text { do poeta }\end{array}$ & Ao pé da mesa & Décima - Tipo B & $\begin{array}{l}\text { Norma } \\
\text { padrão }\end{array}$ \\
\hline 241 & $\begin{array}{l}\text { Mote: Faça uma glosa } \\
\text { para mim }\end{array}$ & Ao pé da mesa & Décima - Tipo B & $\begin{array}{l}\text { Norma } \\
\text { padrão }\end{array}$ \\
\hline 242 & $\begin{array}{l}\text { Mote: O jeito é viver } \\
\text { latindo }\end{array}$ & Ao pé da mesa & Décima - Tipo B & $\begin{array}{l}\text { Norma } \\
\text { padrão }\end{array}$ \\
\hline 243 & $\begin{array}{l}\text { Mote: A careta do } \\
\text { macaco }\end{array}$ & Ao pé da mesa & Décima - Tipo B & $\begin{array}{l}\text { Norma } \\
\text { padrão }\end{array}$ \\
\hline 244 & $\begin{array}{l}\text { Mote: A onça saiu da } \\
\text { cova }\end{array}$ & Ao pé da mesa & Décima - Tipo B & $\begin{array}{l}\text { Norma } \\
\text { padrão }\end{array}$ \\
\hline 245 & $\begin{array}{l}\text { Mote: No cavalo Pantera } \\
\text { vou pegar / quinta-feira, } \\
\text { na mata, o boi Teimoso }\end{array}$ & Ao pé da mesa & Décima - Tipo B & $\begin{array}{l}\text { Norma } \\
\text { padrão }\end{array}$ \\
\hline 246 & $\begin{array}{l}\text { Mote: Cacareja a galinha } \\
\text { no terreiro / acabando o } \\
\text { silêncio do sertão }\end{array}$ & Ao pé da mesa & Décima - Tipo B & $\begin{array}{l}\text { Norma } \\
\text { padrão }\end{array}$ \\
\hline 247 & $\begin{array}{l}\text { Mote: A cabeça da gente } \\
\text { vale ouro / para aquele } \\
\text { que sabe aproveitar }\end{array}$ & Ao pé da mesa & Décima - Tipo B & $\begin{array}{l}\text { Norma } \\
\text { padrão }\end{array}$ \\
\hline 248 & $\begin{array}{l}\text { Mote: No meu céu passa } \\
\text { a nuvem da saudade / } \\
\text { derramando a neblina do }\end{array}$ & Ao pé da mesa & Décima - Tipo B & $\begin{array}{l}\text { Norma } \\
\text { padrão }\end{array}$ \\
\hline
\end{tabular}




\begin{tabular}{|c|c|c|c|c|}
\hline & meu pranto & & & \\
\hline 249 & $\begin{array}{l}\text { Mote: Só aquele que já } \\
\text { calçou sapato / é quem } \\
\text { sabe o lugar que o mesmo } \\
\text { aperta }\end{array}$ & Ao pé da mesa & Décima - Tipo B & $\begin{array}{l}\text { Norma } \\
\text { padrão }\end{array}$ \\
\hline 250 & $\begin{array}{l}\text { Mote: Pirilampos } \\
\text { brilhando pela mata }\end{array}$ & Ao pé da mesa & Décima - Tipo B & $\begin{array}{l}\text { Norma } \\
\text { padrão }\end{array}$ \\
\hline 251 & $\begin{array}{l}\text { Mote: Nas manhãs } \\
\text { luminosas do sertão }\end{array}$ & Ao pé da mesa & Décima - Tipo B & $\begin{array}{l}\text { Norma } \\
\text { padrão }\end{array}$ \\
\hline 252 & $\begin{array}{l}\text { Mote: Acertou na cabeça } \\
\text { de um preá }\end{array}$ & Ao pé da mesa & Décima - Tipo B & $\begin{array}{l}\text { Norma } \\
\text { padrão }\end{array}$ \\
\hline 253 & $\begin{array}{l}\text { Mote: Aqui dentro deste } \\
\text { mundo / todo mundo } \\
\text { nasce e morre }\end{array}$ & Ao pé da mesa & Décima - Tipo B & $\begin{array}{l}\text { Norma } \\
\text { padrão }\end{array}$ \\
\hline 254 & $\begin{array}{l}\text { Mote: Um passarinho } \\
\text { cantava / na copa de um } \\
\text { catolé }\end{array}$ & Ao pé da mesa & Décima - Tipo B & $\begin{array}{l}\text { Norma } \\
\text { padrão }\end{array}$ \\
\hline 255 & $\begin{array}{l}\text { Mote: Quem nunca sentiu } \\
\text { saudade }\end{array}$ & Ao pé da mesa & Décima - Tipo B & $\begin{array}{l}\text { Norma } \\
\text { padrão }\end{array}$ \\
\hline 256 & $\begin{array}{l}\text { Mote: Você paga meu } \\
\text { dinheiro }\end{array}$ & Ao pé da mesa & Décima - Tipo B & $\begin{array}{l}\text { Norma } \\
\text { padrão }\end{array}$ \\
\hline 257 & $\begin{array}{l}\text { Mote: Com a maca nas } \\
\text { costas pelo mundo / } \\
\text { procurando um lugar para } \\
\text { viver }\end{array}$ & Ao pé da mesa & Décima - Tipo B & $\begin{array}{l}\text { Norma } \\
\text { padrão }\end{array}$ \\
\hline 258 & $\begin{array}{l}\text { Mote: Ninguém pode } \\
\text { viver sem amizade / neste } \\
\text { mundo de tanta confusão }\end{array}$ & Ao pé da mesa & Décima - Tipo B & $\begin{array}{l}\text { Norma } \\
\text { padrão }\end{array}$ \\
\hline 259 & $\begin{array}{l}\text { Mote: O sorriso da gente } \\
\text { é uma chama / de acender } \\
\text { alegria, paz a amor }\end{array}$ & Ao pé da mesa & Décima - Tipo B & $\begin{array}{l}\text { Norma } \\
\text { padrão }\end{array}$ \\
\hline 260 & $\begin{array}{l}\text { Mote: Seu poder vemos } \\
\text { no romper da aurora / na } \\
\text { voz bonita do corrupião }\end{array}$ & Ao pé da mesa & Décima - Tipo B & $\begin{array}{l}\text { Norma } \\
\text { padrão }\end{array}$ \\
\hline 261 & $\begin{array}{l}\text { Mote: O cigarro na } \\
\text { velhice / é companheiro } \\
\text { fiel }\end{array}$ & Ao pé da mesa & Décima - Tipo B & $\begin{array}{l}\text { Norma } \\
\text { padrão }\end{array}$ \\
\hline 262 & $\begin{array}{l}\text { Mote: Dentro das grades } \\
\text { gemia / se lembrando do } \\
\text { finado }\end{array}$ & Ao pé da mesa & Décima - Tipo B & $\begin{array}{l}\text { Norma } \\
\text { padrão }\end{array}$ \\
\hline 263 & $\begin{array}{l}\text { Mote: Danou-lhe o chifre } \\
\text { no bucho / que as tripas } \\
\text { saltaram fora }\end{array}$ & Ao pé da mesa & Décima - Tipo B & $\begin{array}{l}\text { Norma } \\
\text { padrão }\end{array}$ \\
\hline 264 & $\begin{array}{l}\text { Mote: A saudade de } \\
\text { Vicente / abala o meu } \\
\text { coração }\end{array}$ & Ao pé da mesa & Décima - Tipo B & $\begin{array}{l}\text { Norma } \\
\text { padrão }\end{array}$ \\
\hline 265 & $\begin{array}{l}\text { Mote: Se benzeu, rezou o } \\
\text { credo / e choveu na } \\
\text { mesma hora }\end{array}$ & Ao pé da mesa & Décima - Tipo B & $\begin{array}{l}\text { Norma } \\
\text { padrão }\end{array}$ \\
\hline
\end{tabular}




\begin{tabular}{|c|c|c|c|c|}
\hline 266 & $\begin{array}{l}\text { Mote: Quem fuma } \\
\text { apressa a viagem / em } \\
\text { direção do outro mundo }\end{array}$ & Ao pé da mesa & Décima - Tipo B & $\begin{array}{l}\text { Norma } \\
\text { padrão }\end{array}$ \\
\hline 267 & $\begin{array}{l}\text { Mote: Parecia um } \\
\text { passarinho }\end{array}$ & Ao pé da mesa & Décima - Tipo B & $\begin{array}{l}\text { Norma } \\
\text { padrão }\end{array}$ \\
\hline 268 & $\begin{array}{l}\text { Mote: Caíram dez } \\
\text { parafusos }\end{array}$ & Ao pé da mesa & Décima - Tipo B & $\begin{array}{l}\text { Norma } \\
\text { padrão }\end{array}$ \\
\hline 269 & $\begin{array}{l}\text { Mote: Sem haver chuva } \\
\text { na terra / não pode haver } \\
\text { produção }\end{array}$ & Ao pé da mesa & Décima - Tipo B & $\begin{array}{l}\text { Norma } \\
\text { padrão }\end{array}$ \\
\hline 270 & $\begin{array}{l}\text { Mote: O meu mote é um } \\
\text { cabresto / de encabrestar } \\
\text { glosador }\end{array}$ & Ao pé da mesa & Décima - Tipo B & $\begin{array}{l}\text { Norma } \\
\text { padrão }\end{array}$ \\
\hline 271 & $\begin{array}{l}\text { Mote: Poeta tenha } \\
\text { cuidado / fazer glosa é } \\
\text { deste jeito }\end{array}$ & Ao pé da mesa & Décima - Tipo B & $\begin{array}{l}\text { Norma } \\
\text { padrão }\end{array}$ \\
\hline 272 & $\begin{array}{l}\text { Mote: A seca no meu } \\
\text { sertão / faz o legume } \\
\text { secar }\end{array}$ & Ao pé da mesa & Décima - Tipo B & $\begin{array}{l}\text { Norma } \\
\text { padrão }\end{array}$ \\
\hline 273 & $\begin{array}{l}\text { Mote: Ficou tremendo } \\
\text { amarelo / tal qual um } \\
\text { mamão maduro }\end{array}$ & Ao pé da mesa & Décima - Tipo B & $\begin{array}{l}\text { Norma } \\
\text { padrão }\end{array}$ \\
\hline 274 & $\begin{array}{l}\text { Mote: Três vezes caiu no } \\
\text { chão }\end{array}$ & Ao pé da mesa & Décima - Tipo B & $\begin{array}{l}\text { Norma } \\
\text { padrão }\end{array}$ \\
\hline 275 & $\begin{array}{l}\text { Mote: Sofreu igualmente } \\
\text { um pinto / nas unhas de } \\
\text { um gavião }\end{array}$ & Ao pé da mesa & Décima - Tipo B & $\begin{array}{l}\text { Norma } \\
\text { padrão }\end{array}$ \\
\hline 276 & $\begin{array}{l}\text { Mote: A briga desta } \\
\text { canalha }\end{array}$ & Ao pé da mesa & Décima - Tipo B & $\begin{array}{l}\text { Norma } \\
\text { padrão }\end{array}$ \\
\hline 277 & $\begin{array}{l}\text { Mote: Precisamos } \\
\text { encontrar / o livro de } \\
\text { Dominique }\end{array}$ & Ao pé da mesa & Décima - Tipo B & $\begin{array}{l}\text { Norma } \\
\text { padrão }\end{array}$ \\
\hline 278 & $\begin{array}{l}\text { Mote: É prazer da } \\
\text { natureza / o canto do } \\
\text { passarinho }\end{array}$ & Ao pé da mesa & Décima - Tipo B & $\begin{array}{l}\text { Norma } \\
\text { padrão }\end{array}$ \\
\hline 279 & $\begin{array}{l}\text { Mote: Pra quem tem bom } \\
\text { pensamento / a glosa } \\
\text { sempre aparece }\end{array}$ & Ao pé da mesa & Décima - Tipo B & $\begin{array}{l}\text { Norma } \\
\text { padrão }\end{array}$ \\
\hline 280 & $\begin{array}{l}\text { Mote: O Luiz Dantas } \\
\text { Quezado / foi grande na } \\
\text { poesia }\end{array}$ & Ao pé da mesa & Décima - Tipo B & $\begin{array}{l}\text { Norma } \\
\text { padrão }\end{array}$ \\
\hline 281 & $\begin{array}{l}\text { Mote: Pensando ser } \\
\text { borboleta }\end{array}$ & Ao pé da mesa & Décima - Tipo B & $\begin{array}{l}\text { Norma } \\
\text { padrão }\end{array}$ \\
\hline 282 & $\begin{array}{l}\text { Mote: Toda criatura } \\
\text { humana / tem o seu valor } \\
\text { divino }\end{array}$ & Ao pé da mesa & Décima - Tipo B & $\begin{array}{l}\text { Norma } \\
\text { padrão }\end{array}$ \\
\hline 283 & $\begin{array}{l}\text { Mote: Nos meus oitenta e } \\
\text { sete anos / ainda dou meu } \\
\text { recado }\end{array}$ & Ao pé da mesa & Décima - Tipo B & $\begin{array}{l}\text { Norma } \\
\text { padrão }\end{array}$ \\
\hline
\end{tabular}




\begin{tabular}{|c|c|c|c|c|}
\hline 284 & $\begin{array}{l}\text { Mote: Sai um bonito } \\
\text { gorgeio / do bico de um } \\
\text { sabiá }\end{array}$ & Ao pé da mesa & Décima - Tipo B & $\begin{array}{l}\text { Norma } \\
\text { padrão }\end{array}$ \\
\hline 285 & $\begin{array}{l}\text { Mote: Formiga que cria } \\
\text { asa / vai por certo se } \\
\text { perder }\end{array}$ & Ao pé da mesa & Décima - Tipo B & $\begin{array}{l}\text { Norma } \\
\text { padrão }\end{array}$ \\
\hline 286 & $\begin{array}{l}\text { Mote: Pendido dentro do } \\
\text { rio }\end{array}$ & Ao pé da mesa & Décima - Tipo B & $\begin{array}{l}\text { Norma } \\
\text { padrão }\end{array}$ \\
\hline 287 & $\begin{array}{l}\text { Mote: Não sei se deixo } \\
\text { saudade / mas falta deixo } \\
\text { demais }\end{array}$ & Ao pé da mesa & Décima - Tipo B & $\begin{array}{l}\text { Norma } \\
\text { padrão }\end{array}$ \\
\hline 288 & $\begin{array}{l}\text { Mote: O professor enche } \\
\text { o saco / enciumado do } \\
\text { aluno }\end{array}$ & Ao pé da mesa & Décima - Tipo B & $\begin{array}{l}\text { Norma } \\
\text { padrão }\end{array}$ \\
\hline 289 & $\begin{array}{l}\text { Mote: É grande quebra- } \\
\text { cabeça }\end{array}$ & Ao pé da mesa & Décima - Tipo B & $\begin{array}{l}\text { Norma } \\
\text { padrão }\end{array}$ \\
\hline 290 & $\begin{array}{l}\text { Mote: Gostei de Mercê de } \\
\text { Sousa / grande cantora } \\
\text { argentina }\end{array}$ & Ao pé da mesa & Décima - Tipo B & $\begin{array}{l}\text { Norma } \\
\text { padrão }\end{array}$ \\
\hline 291 & $\begin{array}{l}\text { Mote: Será que o chifre } \\
\text { do Diabo / é mesmo feito } \\
\text { de fogo? }\end{array}$ & Ao pé da mesa & Décima - Tipo B & $\begin{array}{l}\text { Norma } \\
\text { padrão }\end{array}$ \\
\hline 292 & $\begin{array}{l}\text { Mote: Sua glosa está bem } \\
\text { feita / obrigado meu } \\
\text { amigo }\end{array}$ & Ao pé da mesa & Décima - Tipo B & $\begin{array}{l}\text { Norma } \\
\text { padrão }\end{array}$ \\
\hline 293 & $\begin{array}{l}\text { Mote: Escutei a voz do } \\
\text { vento / rugindo de } \\
\text { madrugada }\end{array}$ & Ao pé da mesa & Décima - Tipo B & $\begin{array}{l}\text { Norma } \\
\text { padrão }\end{array}$ \\
\hline 294 & $\begin{array}{l}\text { Mote: Eu só quero quem } \\
\text { me quer / quem não me } \\
\text { quer eu não quero }\end{array}$ & Ao pé da mesa & Décima - Tipo B & $\begin{array}{l}\text { Norma } \\
\text { padrão }\end{array}$ \\
\hline 295 & $\begin{array}{l}\text { Mote: Vi na luz do teu } \\
\text { olhar / o amor entrando } \\
\text { em mim }\end{array}$ & Ao pé da mesa & Décima - Tipo B & $\begin{array}{l}\text { Norma } \\
\text { padrão }\end{array}$ \\
\hline 296 & Mote: $\mathrm{O}$ ateu acreditou & Ao pé da mesa & Décima - Tipo B & $\begin{array}{l}\text { Norma } \\
\text { padrão }\end{array}$ \\
\hline 297 & $\begin{array}{l}\text { Mote: Assim que o } \\
\text { graúna canta / desejo } \\
\text { cantar também }\end{array}$ & Ao pé da mesa & Décima - Tipo B & $\begin{array}{l}\text { Norma } \\
\text { padrão }\end{array}$ \\
\hline 298 & $\begin{array}{l}\text { Mote: Quero quebrar a } \\
\text { castanha / do mote que } \\
\text { aparecer }\end{array}$ & Ao pé da mesa & Décima - Tipo B & $\begin{array}{l}\text { Norma } \\
\text { padrão }\end{array}$ \\
\hline 299 & $\begin{array}{l}\text { Mote: Tem gente que diz } \\
\text { que sabe / porém não } \\
\text { sabe de nada }\end{array}$ & Ao pé da mesa & Décima - Tipo B & $\begin{array}{l}\text { Norma } \\
\text { padrão }\end{array}$ \\
\hline 300 & $\begin{array}{l}\text { Mote: Gostei do seu } \\
\text { improviso }\end{array}$ & Ao pé da mesa & Décima - Tipo B & $\begin{array}{l}\text { Norma } \\
\text { padrão }\end{array}$ \\
\hline 301 & $\begin{array}{l}\text { Mote: A chuva não quer } \\
\text { chegar }\end{array}$ & Ao pé da mesa & Décima - Tipo B & $\begin{array}{l}\text { Norma } \\
\text { padrão }\end{array}$ \\
\hline
\end{tabular}




\begin{tabular}{|c|c|c|c|c|}
\hline 302 & $\begin{array}{l}\text { Mote: No museu do } \\
\text { Patativa }\end{array}$ & Ao pé da mesa & Décima - Tipo B & $\begin{array}{l}\text { Norma } \\
\text { padrão }\end{array}$ \\
\hline 303 & Mote: Pior poderia ser & Ao pé da mesa & Décima - Tipo B & $\begin{array}{l}\text { Norma } \\
\text { padrão }\end{array}$ \\
\hline 304 & $\begin{array}{l}\text { Mote: Estraçalhou a } \\
\text { cabeça }\end{array}$ & Ao pé da mesa & Décima - Tipo B & $\begin{array}{l}\text { Norma } \\
\text { padrão }\end{array}$ \\
\hline 305 & $\begin{array}{l}\text { Mote: Recordando meu } \\
\text { passado }\end{array}$ & Ao pé da mesa & Décima - Tipo B & $\begin{array}{l}\text { Norma } \\
\text { padrão }\end{array}$ \\
\hline 306 & $\begin{array}{l}\text { Mote: Brincando de } \\
\text { poesia }\end{array}$ & Ao pé da mesa & Décima - Tipo B & $\begin{array}{l}\text { Norma } \\
\text { padrão }\end{array}$ \\
\hline 307 & $\begin{array}{l}\text { Mote: A minha lira é um } \\
\text { suco / das uvas do paraíso }\end{array}$ & Ao pé da mesa & Décima - Tipo B & $\begin{array}{l}\text { Norma } \\
\text { padrão }\end{array}$ \\
\hline 308 & $\begin{array}{l}\text { Mote: Não é como } \\
\text { satanaz / mas anda pega- } \\
\text { não-pega }\end{array}$ & Ao pé da mesa & Décima - Tipo B & $\begin{array}{l}\text { Norma } \\
\text { padrão }\end{array}$ \\
\hline 309 & $\begin{array}{l}\text { Mote: A vitória do } \\
\text { prefeito / só as urnas nos } \\
\text { dirão }\end{array}$ & Ao pé da mesa & Décima - Tipo B & $\begin{array}{l}\text { Norma } \\
\text { padrão }\end{array}$ \\
\hline 310 & $\begin{array}{l}\text { Mote: A fruta da } \\
\text { cajazeira / dá um suco } \\
\text { saboroso }\end{array}$ & Ao pé da mesa & Décima - Tipo B & $\begin{array}{l}\text { Norma } \\
\text { padrão }\end{array}$ \\
\hline 311 & $\begin{array}{l}\text { Mote: Ela plantada não } \\
\text { nasce }\end{array}$ & Ao pé da mesa & Décima - Tipo B & $\begin{array}{l}\text { Norma } \\
\text { padrão }\end{array}$ \\
\hline 312 & $\begin{array}{l}\text { Mote: Voa, borboleta, } \\
\text { voa }\end{array}$ & Ao pé da mesa & Décima - Tipo B & $\begin{array}{l}\text { Norma } \\
\text { padrão }\end{array}$ \\
\hline 313 & $\begin{array}{l}\text { Mote: A natureza fez } \\
\text { tudo / mas não fez ela pra } \\
\text { mim }\end{array}$ & Ao pé da mesa & Décima - Tipo B & $\begin{array}{l}\text { Norma } \\
\text { padrão }\end{array}$ \\
\hline 314 & $\begin{array}{l}\text { Mote: Esta vida é } \\
\text { pequenina }\end{array}$ & Ao pé da mesa & Décima - Tipo B & $\begin{array}{l}\text { Norma } \\
\text { padrão }\end{array}$ \\
\hline 315 & $\begin{array}{l}\text { Mote: Na cantiga da } \\
\text { peitica / eu vejo a safra } \\
\text { segura }\end{array}$ & Ao pé da mesa & Décima - Tipo B & $\begin{array}{l}\text { Norma } \\
\text { padrão }\end{array}$ \\
\hline 316 & $\begin{array}{l}\text { Mote: A poesia é dom / } \\
\text { dado pela natureza }\end{array}$ & Ao pé da mesa & Décima - Tipo B & $\begin{array}{l}\text { Norma } \\
\text { padrão }\end{array}$ \\
\hline 317 & $\begin{array}{l}\text { Mote: Nunca mais comi } \\
\text { galinha }\end{array}$ & Ao pé da mesa & Décima - Tipo B & $\begin{array}{l}\text { Norma } \\
\text { padrão }\end{array}$ \\
\hline 318 & $\begin{array}{l}\text { Mote: A cobra saiu do } \\
\text { oco / trazendo um rato no } \\
\text { dente }\end{array}$ & Ao pé da mesa & Décima - Tipo B & $\begin{array}{l}\text { Norma } \\
\text { padrão }\end{array}$ \\
\hline 319 & $\begin{array}{l}\text { Mote: Jurema, vá se } \\
\text { aquietar }\end{array}$ & Ao pé da mesa & Décima - Tipo B & $\begin{array}{l}\text { Norma } \\
\text { padrão }\end{array}$ \\
\hline 320 & $\begin{array}{l}\text { Mote: A desgraça do } \\
\text { agregado / é ter um falso } \\
\text { patrão }\end{array}$ & Ao pé da mesa & Décima - Tipo B & $\begin{array}{l}\text { Norma } \\
\text { padrão }\end{array}$ \\
\hline 321 & $\begin{array}{l}\text { Mote: Transpus o canal } \\
\text { da Mancha / Montado em } \\
\text { um tubarão }\end{array}$ & Ao pé da mesa & Décima - Tipo B & $\begin{array}{l}\text { Norma } \\
\text { padrão }\end{array}$ \\
\hline 322 & Mote: Jesus não pôde & Ao pé da mesa & Décima - Tipo B & Norma \\
\hline
\end{tabular}




\begin{tabular}{|c|c|c|c|c|}
\hline & comer & & & padrão \\
\hline 323 & $\begin{array}{l}\text { Mote: E nem tinha uma } \\
\text { casa pra morar }\end{array}$ & Ao pé da mesa & Décima - Tipo B & $\begin{array}{l}\text { Norma } \\
\text { padrão }\end{array}$ \\
\hline 324 & $\begin{array}{l}\text { Mote: Que a mesada era } \\
\text { carne de urubu }\end{array}$ & Ao pé da mesa & Décima - Tipo B & $\begin{array}{l}\text { Norma } \\
\text { padrão }\end{array}$ \\
\hline 325 & $\begin{array}{l}\text { Mote: O que vi nas } \\
\text { barreiras do riacho }\end{array}$ & Ao pé da mesa & Décima - Tipo B & $\begin{array}{l}\text { Norma } \\
\text { padrão }\end{array}$ \\
\hline 326 & $\begin{array}{l}\text { Mote: Só tem um cabelo } \\
\text { branco / bem na pontinha } \\
\text { do rabo }\end{array}$ & Ao pé da mesa & Décima - Tipo B & $\begin{array}{l}\text { Norma } \\
\text { padrão }\end{array}$ \\
\hline 327 & $\begin{array}{l}\text { Mote: O que você está } \\
\text { pensando? }\end{array}$ & Ao pé da mesa & Décima - Tipo B & $\begin{array}{l}\text { Norma } \\
\text { padrão }\end{array}$ \\
\hline 328 & $\begin{array}{l}\text { Mote: } \mathrm{O} \text { diabo em forma } \\
\text { de gente }\end{array}$ & Ao pé da mesa & Décima - Tipo B & $\begin{array}{l}\text { Norma } \\
\text { padrão }\end{array}$ \\
\hline 329 & $\begin{array}{l}\text { Mote: Mote vai e mote } \\
\text { vem }\end{array}$ & Ao pé da mesa & Décima - Tipo B & $\begin{array}{l}\text { Norma } \\
\text { padrão }\end{array}$ \\
\hline 330 & $\begin{array}{l}\text { Mote: Divertindo com a } \\
\text { rima }\end{array}$ & Ao pé da mesa & Décima - Tipo B & $\begin{array}{l}\text { Norma } \\
\text { padrão }\end{array}$ \\
\hline 331 & Mote: Na fita do gravador & Ao pé da mesa & Décima - Tipo B & $\begin{array}{l}\text { Norma } \\
\text { padrão }\end{array}$ \\
\hline 332 & $\begin{array}{l}\text { Mote: } \mathrm{O} \text { fumo mata a } \\
\text { pessoa e a gente não } \\
\text { deixa o fumo }\end{array}$ & Melhores Poemas & $\begin{array}{l}\text { Décima - Tipo } \\
\text { C }\end{array}$ & $\begin{array}{l}\text { Norma } \\
\text { padrão }\end{array}$ \\
\hline 333 & $\begin{array}{l}\text { Mote: A senhorinha o que } \\
\text { pensa? / Sou também de } \\
\text { carne e osso. }\end{array}$ & $\begin{array}{l}\text { Novos poemas } \\
\text { comentados }\end{array}$ & $\begin{array}{l}\text { Décima-Tipo } \\
\text { B }\end{array}$ & $\begin{array}{l}\text { Norma } \\
\text { padrão }\end{array}$ \\
\hline 334 & $\begin{array}{l}\text { Mote: O comunismo fatal } \\
\text { / não queremos no Brasil }\end{array}$ & Cordel & $\begin{array}{l}\text { Décima-Tipo } \\
\text { C }\end{array}$ & $\begin{array}{l}\text { Norma } \\
\text { padrão }\end{array}$ \\
\hline 335 & $\begin{array}{l}\text { Mote: O regime } \\
\text { comunista / é contra a } \\
\text { religião }\end{array}$ & Cordel & $\begin{array}{l}\text { Décima-Tipo } \\
\text { C }\end{array}$ & $\begin{array}{l}\text { Norma } \\
\text { padrão }\end{array}$ \\
\hline 336 & $\begin{array}{l}\text { Mote: Quem apoia o } \\
\text { comunismo / gosta do } \\
\text { Diabo também }\end{array}$ & Cordel & $\begin{array}{l}\text { Décima - Tipo } \\
\text { C }\end{array}$ & $\begin{array}{l}\text { Norma } \\
\text { padrão }\end{array}$ \\
\hline 337 & $\begin{array}{l}\text { Mote: Lá na Rússia o } \\
\text { agricultor / só come } \\
\text { quando lhe dão }\end{array}$ & Cordel & $\begin{array}{l}\text { Décima - Tipo } \\
\text { C }\end{array}$ & $\begin{array}{l}\text { Norma } \\
\text { padrão }\end{array}$ \\
\hline 338 & $\begin{array}{l}\text { Mote: O comunista é } \\
\text { manhoso / e falso como a } \\
\text { serpente }\end{array}$ & Cordel & $\begin{array}{l}\text { Décima - Tipo } \\
\text { C }\end{array}$ & $\begin{array}{l}\text { Norma } \\
\text { padrão }\end{array}$ \\
\hline 339 & $\begin{array}{l}\text { Mote: Na doutrina de } \\
\text { Lenin / só reina a } \\
\text { imoralidade }\end{array}$ & Cordel & $\begin{array}{l}\text { Décima-Tipo } \\
\text { C }\end{array}$ & $\begin{array}{l}\text { Norma } \\
\text { padrão }\end{array}$ \\
\hline 340 & $\begin{array}{l}\text { Mote: Ser comunista é ser } \\
\text { bruto / é uma e a mesma } \\
\text { cousa }\end{array}$ & Cordel & $\begin{array}{l}\text { Décima-Tipo } \\
\text { C }\end{array}$ & $\begin{array}{l}\text { Norma } \\
\text { padrão }\end{array}$ \\
\hline 341 & $\begin{array}{l}\text { Mote: Onde o comunismo } \\
\text { manda / não reina a } \\
\text { democracia }\end{array}$ & Cordel & $\begin{array}{l}\text { Décima - Tipo } \\
\text { C }\end{array}$ & $\begin{array}{l}\text { Norma } \\
\text { padrão }\end{array}$ \\
\hline
\end{tabular}




\begin{tabular}{|c|c|c|c|c|}
\hline 342 & Mulher Valente & Aqui tem coisa & Quartetos & $\begin{array}{l}\text { Norma } \\
\text { padrão }\end{array}$ \\
\hline 343 & Musa buliçosa & $\begin{array}{l}\text { Balceiro / Novos } \\
\text { poemas } \\
\text { comentados }\end{array}$ & Soneto & $\begin{array}{l}\text { Norma } \\
\text { padrão }\end{array}$ \\
\hline 344 & $\mathrm{Na}$ fita do gravador & $\begin{array}{l}\text { Novos poemas } \\
\text { comentados }\end{array}$ & Sextilha Cordel & $\begin{array}{l}\text { Norma } \\
\text { padrão }\end{array}$ \\
\hline 345 & Nanã & $\begin{array}{l}\text { Balceiro / } \\
\text { Melhores Poemas / } \\
\text { Novos poemas } \\
\text { comentados }\end{array}$ & Soneto & $\begin{array}{l}\text { Norma } \\
\text { padrão }\end{array}$ \\
\hline 346 & No Cemitério & Ispinho e Fulô & Soneto & $\begin{array}{l}\text { Norma } \\
\text { padrão }\end{array}$ \\
\hline 347 & No meu Sertão & $\begin{array}{l}\text { Inspiração } \\
\text { nordestina }\end{array}$ & $\begin{array}{l}\text { Décimas - Tipo } \\
\text { C }\end{array}$ & $\begin{array}{l}\text { Variante } \\
\text { matuta }\end{array}$ \\
\hline 348 & No Terreiro da Choupana & $\begin{array}{l}\text { Cante lá que eu } \\
\text { canto cá }\end{array}$ & $\begin{array}{l}\text { Décimas - Tipo } \\
\text { A }\end{array}$ & $\begin{array}{l}\text { Variante } \\
\text { matuta }\end{array}$ \\
\hline 349 & $\begin{array}{l}\text { Nordestino Sim, } \\
\text { Nordestinado, Não }\end{array}$ & Ispinho e Fulô & $\begin{array}{l}\text { Sextilha } \\
\text { Moderna }\end{array}$ & $\begin{array}{l}\text { Norma } \\
\text { padrão }\end{array}$ \\
\hline 350 & O Agregado & $\begin{array}{l}\text { Inspiração } \\
\text { nordestina / Cante } \\
\text { lá que eu canto cá }\end{array}$ & Quartetos & $\begin{array}{l}\text { Variante } \\
\text { matuta }\end{array}$ \\
\hline 351 & O Agregado e o Operário & Ispinho e Fulô & $\begin{array}{l}\text { Décimas - Tipo } \\
\text { A }\end{array}$ & $\begin{array}{l}\text { Norma } \\
\text { padrão }\end{array}$ \\
\hline 352 & O Alco e a Gazolina & Ispinho e Fulô & $\begin{array}{l}\text { Décimas - Tipo } \\
\text { A }\end{array}$ & $\begin{array}{l}\text { Variante } \\
\text { matuta }\end{array}$ \\
\hline 353 & $\begin{array}{l}\text { O banco do Chico } \\
\text { Rosado }\end{array}$ & $\begin{array}{l}\text { Melhores Poemas / } \\
\text { Novos poemas } \\
\text { comentados }\end{array}$ & $\begin{array}{l}\text { Décimas - Tipo } \\
\text { B }\end{array}$ & $\begin{array}{l}\text { Norma } \\
\text { padrão }\end{array}$ \\
\hline 354 & O Beato Zé Lourenço & Ispinho e Fulô & $\begin{array}{l}\text { Sextilha } \\
\text { Moderna }\end{array}$ & $\begin{array}{l}\text { Norma } \\
\text { padrão }\end{array}$ \\
\hline 355 & O Bicho mais Feroz & Ispinho e Fulô & Irregulares & $\begin{array}{l}\text { Norma } \\
\text { padrão }\end{array}$ \\
\hline 356 & $\begin{array}{l}\text { O Bode de Miguel Boato } \\
\text { e o efeito da maconha }\end{array}$ & $\begin{array}{l}\text { Aqui tem coisa / } \\
\text { Cordel }\end{array}$ & $\begin{array}{l}\text { Décimas - Tipo } \\
\text { A }\end{array}$ & $\begin{array}{l}\text { Norma } \\
\text { padrão }\end{array}$ \\
\hline 357 & O Bode do Serafim & $\begin{array}{l}\text { Melhores Poemas / } \\
\text { Novos poemas } \\
\text { comentados }\end{array}$ & $\begin{array}{l}\text { Décimas - Tipo } \\
\text { B }\end{array}$ & $\begin{array}{l}\text { Norma } \\
\text { padrão }\end{array}$ \\
\hline 358 & $\begin{array}{l}\text { O Boi Zebu e as } \\
\text { Formigas }\end{array}$ & Ispinho e Fulô & $\begin{array}{l}\text { Décimas - Tipo } \\
\text { A }\end{array}$ & $\begin{array}{l}\text { Variante } \\
\text { matuta }\end{array}$ \\
\hline 359 & O Burro & $\begin{array}{l}\text { Inspiração } \\
\text { nordestina / Cante } \\
\text { lá que eu canto cá }\end{array}$ & Soneto & $\begin{array}{l}\text { Norma } \\
\text { padrão }\end{array}$ \\
\hline 360 & O Caçador $^{77}$ & $\begin{array}{l}\text { Inspiração } \\
\text { nordestina / Aqui } \\
\text { tem coisa }\end{array}$ & $\begin{array}{l}\text { Sextilha } \\
\text { Moderna }\end{array}$ & $\begin{array}{l}\text { Variante } \\
\text { matuta }\end{array}$ \\
\hline
\end{tabular}

77 “O Caçadô”. In: Aqui tem coisa (2012). 


\begin{tabular}{|c|c|c|c|c|}
\hline 361 & O Casebre & $\begin{array}{l}\text { Inspiração } \\
\text { nordestina / Cante } \\
\text { lá que eu canto cá }\end{array}$ & Quartetos & $\begin{array}{l}\text { Norma } \\
\text { padrão }\end{array}$ \\
\hline 362 & O Castigo do Vaidoso & $\begin{array}{l}\text { Cante lá que eu } \\
\text { canto cá }\end{array}$ & Soneto & $\begin{array}{l}\text { Norma } \\
\text { padrão }\end{array}$ \\
\hline 363 & O Controlista & $\begin{array}{l}\text { Cante lá que eu } \\
\text { canto cá }\end{array}$ & $\begin{array}{l}\text { Décimas - Tipo } \\
\text { A }\end{array}$ & $\begin{array}{l}\text { Variante } \\
\text { matuta }\end{array}$ \\
\hline 364 & O Crime de Cariús & Cordel & Sextilha Cordel & $\begin{array}{l}\text { Norma } \\
\text { padrão }\end{array}$ \\
\hline 365 & O Desgosto do Medêro & Ispinho e Fulô & Septilhas & $\begin{array}{l}\text { Variante } \\
\text { matuta }\end{array}$ \\
\hline 366 & O Doutor Raiz & $\begin{array}{l}\text { Inspiração } \\
\text { nordestina / Cordel }\end{array}$ & Irregulares & $\begin{array}{l}\text { Norma } \\
\text { padrão }\end{array}$ \\
\hline 367 & O Frangão da Meirislene & Aqui tem coisa & $\begin{array}{l}\text { Décimas - Tipo } \\
\text { A }\end{array}$ & $\begin{array}{l}\text { Norma } \\
\text { padrão }\end{array}$ \\
\hline 368 & O Fruito Milagroso & $\begin{array}{l}\text { Novos poemas } \\
\text { comentados }\end{array}$ & $\begin{array}{l}\text { Décimas - Tipo } \\
\text { A }\end{array}$ & $\begin{array}{l}\text { Variante } \\
\text { matuta }\end{array}$ \\
\hline 369 & $\begin{array}{l}\text { O Galo Egoísta e o } \\
\text { Frango Infeliz }\end{array}$ & Ispinho e Fulô & Quartetos & $\begin{array}{l}\text { Norma } \\
\text { padrão }\end{array}$ \\
\hline 370 & O grande prêmio & $\begin{array}{l}\text { Inspiração } \\
\text { nordestina }\end{array}$ & Soneto & $\begin{array}{l}\text { Norma } \\
\text { padrão }\end{array}$ \\
\hline 371 & $\begin{array}{l}\text { O Inferno, o Purgatório e } \\
\text { o Paraíso }\end{array}$ & $\begin{array}{l}\text { Cante lá que eu } \\
\text { canto cá }\end{array}$ & Oitavas & $\begin{array}{l}\text { Norma } \\
\text { padrão }\end{array}$ \\
\hline 372 & O Maió Ladrão & $\begin{array}{l}\text { Cante lá que eu } \\
\text { canto cá }\end{array}$ & Irregulares & $\begin{array}{l}\text { Variante } \\
\text { matuta }\end{array}$ \\
\hline 373 & O Meu Livro & $\begin{array}{l}\text { Ispinho e Fulô / } \\
\text { Cordel }\end{array}$ & $\begin{array}{l}\text { Décimas - Tipo } \\
\text { A }\end{array}$ & $\begin{array}{l}\text { Variante } \\
\text { matuta }\end{array}$ \\
\hline 374 & O Nadador & $\begin{array}{l}\text { Ispinho e Fulô / } \\
\text { Melhores Poemas }\end{array}$ & Quartetos & $\begin{array}{l}\text { Norma } \\
\text { padrão }\end{array}$ \\
\hline 375 & $\begin{array}{l}\text { O Nordestino em São } \\
\text { Paulo }\end{array}$ & Aqui tem coisa & Quartetos & $\begin{array}{l}\text { Norma } \\
\text { padrão }\end{array}$ \\
\hline 376 & O Padre e o Matuto & $\begin{array}{l}\text { Inspiração } \\
\text { nordestina }\end{array}$ & $\begin{array}{l}\text { Décimas - Tipo } \\
\text { C }\end{array}$ & $\begin{array}{l}\text { Norma } \\
\text { padrão e } \\
\text { variante } \\
\text { matuta }\end{array}$ \\
\hline 377 & $\begin{array}{l}\text { O Padre Henrique e o } \\
\text { Dragão da Maldade }\end{array}$ & $\begin{array}{l}\text { Ispinho e Fulô / } \\
\text { Cordel }\end{array}$ & Sextilha Cordel & $\begin{array}{l}\text { Norma } \\
\text { padrão }\end{array}$ \\
\hline 378 & O Parafuso & $\begin{array}{l}\text { Balceiro / } \\
\text { Melhores Poemas }\end{array}$ & Quartetos & $\begin{array}{l}\text { Norma } \\
\text { padrão }\end{array}$ \\
\hline 379 & O Paraíso das Aves & $\begin{array}{l}\text { Inspiração } \\
\text { nordestina }\end{array}$ & Oitavas & $\begin{array}{l}\text { Norma } \\
\text { padrão }\end{array}$ \\
\hline 380 & O Paraíso do Crato & $\begin{array}{l}\text { Cante lá que eu } \\
\text { canto cá }\end{array}$ & $\begin{array}{l}\text { Décimas - Tipo } \\
\text { A }\end{array}$ & $\begin{array}{l}\text { Variante } \\
\text { matuta }\end{array}$ \\
\hline 381 & O Pau D'Arco & $\begin{array}{l}\text { Inspiração } \\
\text { nordestina / Cante } \\
\text { lá que eu canto cá }\end{array}$ & Soneto & $\begin{array}{l}\text { Norma } \\
\text { padrão }\end{array}$ \\
\hline 382 & O Peixe & $\begin{array}{l}\text { Inspiração } \\
\text { nordestina / Cante }\end{array}$ & Soneto & $\begin{array}{l}\text { Norma } \\
\text { padrão }\end{array}$ \\
\hline
\end{tabular}




\begin{tabular}{|c|c|c|c|c|}
\hline & & lá que eu canto cá & & \\
\hline 383 & O Pica-Pau & $\begin{array}{l}\text { Cante lá que eu } \\
\text { canto cá }\end{array}$ & $\begin{array}{l}\text { Décimas - Tipo } \\
\text { A }\end{array}$ & $\begin{array}{l}\text { Variante } \\
\text { matuta }\end{array}$ \\
\hline 384 & O poeta da roça & $\begin{array}{l}\text { Inspiração } \\
\text { nordestina / Cante } \\
\text { lá que eu canto cá }\end{array}$ & Quartetos & $\begin{array}{l}\text { Variante } \\
\text { matuta }\end{array}$ \\
\hline 385 & $\begin{array}{l}\text { O Poeta Patativa e a } \\
\text { Sariema de Totelina }\end{array}$ & $\begin{array}{l}\text { Melhores Poemas / } \\
\text { Balceiro } 2\end{array}$ & $\begin{array}{l}\text { Sextilha } \\
\text { Moderna }\end{array}$ & $\begin{array}{l}\text { Norma } \\
\text { padrão }\end{array}$ \\
\hline 386 & O Prazer da Pipa & Balceiro & Soneto & $\begin{array}{l}\text { Norma } \\
\text { padrão }\end{array}$ \\
\hline 387 & O Puxadô de Roda & $\begin{array}{l}\text { Inspiração } \\
\text { nordestina / Cante } \\
\text { lá que eu canto cá }\end{array}$ & $\begin{array}{l}\text { Décimas - Tipo } \\
\text { A }\end{array}$ & $\begin{array}{l}\text { Variante } \\
\text { matuta }\end{array}$ \\
\hline 388 & O que é Folclore & $\begin{array}{l}\text { Cante lá que eu } \\
\text { canto cá / Melhores } \\
\text { Poemas / Novos } \\
\text { poemas } \\
\text { comentados }\end{array}$ & $\begin{array}{l}\text { Décimas - Tipo } \\
\text { A }\end{array}$ & $\begin{array}{l}\text { Norma } \\
\text { padrão }\end{array}$ \\
\hline 389 & O Rádio ABC & $\begin{array}{l}\text { Cante lá que eu } \\
\text { canto cá }\end{array}$ & $\begin{array}{l}\text { Décimas - Tipo } \\
\text { A }\end{array}$ & $\begin{array}{l}\text { Variante } \\
\text { matuta }\end{array}$ \\
\hline 390 & O que mais dói & $\begin{array}{l}\text { Inspiração } \\
\text { nordestina }\end{array}$ & Soneto & $\begin{array}{l}\text { Norma } \\
\text { padrão }\end{array}$ \\
\hline 391 & O Rapaz do Pé Frio & $\begin{array}{l}\text { Inspiração } \\
\text { nordestina }\end{array}$ & $\begin{array}{l}\text { Décimas - Tipo } \\
\text { B }\end{array}$ & $\begin{array}{l}\text { Norma } \\
\text { padrão }\end{array}$ \\
\hline 392 & O Retrato do Sertão & $\begin{array}{l}\text { Cante lá que eu } \\
\text { canto cá / Melhores } \\
\text { Poemas / Novos } \\
\text { poemas } \\
\text { comentados }\end{array}$ & $\begin{array}{l}\text { Décimas - Tipo } \\
\text { A }\end{array}$ & $\begin{array}{l}\text { Norma } \\
\text { padrão }\end{array}$ \\
\hline 393 & $\mathrm{O}$ rico orguioso & $\begin{array}{l}\text { Cante lá que eu } \\
\text { canto cá }\end{array}$ & $\begin{array}{l}\text { Décimas - Tipo } \\
\text { A }\end{array}$ & $\begin{array}{l}\text { Variante } \\
\text { matuta }\end{array}$ \\
\hline 394 & O Rouxinol e o Ancião & $\begin{array}{l}\text { Inspiração } \\
\text { nordestina / Cante } \\
\text { lá que eu canto cá / } \\
\text { Melhores Poemas }\end{array}$ & $\begin{array}{l}\text { Sextilha } \\
\text { Moderna }\end{array}$ & $\begin{array}{l}\text { Norma } \\
\text { padrão }\end{array}$ \\
\hline 395 & O Sabiá e a Coruja & Balceiro 2 & Quartetos & $\begin{array}{l}\text { Norma } \\
\text { padrão }\end{array}$ \\
\hline 396 & O Sabiá e o Gavião & $\begin{array}{l}\text { Novos poemas } \\
\text { comentados / } \\
\text { Cante lá que eu } \\
\text { canto cá }\end{array}$ & $\begin{array}{l}\text { Décimas - Tipo } \\
\text { A }\end{array}$ & $\begin{array}{l}\text { Variante } \\
\text { matuta }\end{array}$ \\
\hline 397 & $\begin{array}{l}\text { O Sonho de Mané } \\
\text { Feliciano }\end{array}$ & $\begin{array}{l}\text { Cante lá que eu } \\
\text { canto cá }\end{array}$ & $\begin{array}{l}\text { Décimas - Tipo } \\
\text { A }\end{array}$ & $\begin{array}{l}\text { Variante } \\
\text { matuta }\end{array}$ \\
\hline 398 & $\mathrm{O}$ Vaqueiro ${ }^{78}$ & Inspiração & Oitavas & Variante \\
\hline
\end{tabular}

78 “O Vaquêro". In: Cante lá que eu canto cá (1978 e 2014). 


\begin{tabular}{|c|c|c|c|c|}
\hline & & $\begin{array}{l}\text { nordestina / Cante } \\
\text { lá que eu canto cá }\end{array}$ & & matuta \\
\hline 399 & O Vim-vim & $\begin{array}{l}\text { Cante lá que eu } \\
\text { canto cá }\end{array}$ & $\begin{array}{l}\text { Décimas - Tipo } \\
\text { A }\end{array}$ & $\begin{array}{l}\text { Variante } \\
\text { matuta }\end{array}$ \\
\hline 400 & Óios Redondo & Ispinho e Fulô & $\begin{array}{l}\text { Sextilha } \\
\text { Moderna }\end{array}$ & $\begin{array}{l}\text { Variante } \\
\text { matuta }\end{array}$ \\
\hline 401 & Pai Luiz e o Preguiçoso & $\begin{array}{l}\text { Melhores Poemas / } \\
\text { Balceiro } 2\end{array}$ & $\begin{array}{l}\text { Décimas - Tipo } \\
\text { A }\end{array}$ & $\begin{array}{l}\text { Norma } \\
\text { padrão }\end{array}$ \\
\hline 402 & Patativa descontente & $\begin{array}{l}\text { Novos poemas } \\
\text { comentados }\end{array}$ & Quartetos & $\begin{array}{l}\text { Norma } \\
\text { padrão }\end{array}$ \\
\hline 403 & $\begin{array}{l}\text { Patativa do Assaré no } \\
\text { teatro José de Alencar } \\
\text { fazendo uma referência } \\
\text { sobre o imortal folclorista } \\
\text { Leonardo Mota }\end{array}$ & Aqui tem coisa & $\begin{array}{l}\text { Décimas - Tipo } \\
\text { A }\end{array}$ & $\begin{array}{l}\text { Norma } \\
\text { padrão }\end{array}$ \\
\hline 404 & $\begin{array}{l}\text { Patativa e o Hospital São } \\
\text { Francisco }\end{array}$ & Balceiro & Quartetos & $\begin{array}{l}\text { Norma } \\
\text { padrão }\end{array}$ \\
\hline 405 & $\begin{array}{l}\text { Pé quebrado aos índios } \\
\text { do Brasil }\end{array}$ & Ispinho e Fulô & Quartetos & $\begin{array}{l}\text { Norma } \\
\text { padrão }\end{array}$ \\
\hline 406 & $\begin{array}{l}\text { Percorrendo o Nordeste } \\
\text { em Pregação }\end{array}$ & $\begin{array}{l}\text { Melhores Poemas / } \\
\text { Ao pé da mesa }\end{array}$ & Soneto & $\begin{array}{l}\text { Norma } \\
\text { padrão }\end{array}$ \\
\hline 407 & Perfume de Gambá & $\begin{array}{l}\text { Aqui tem coisa / } \\
\text { Melhores Poemas }\end{array}$ & $\begin{array}{l}\text { Sextilha } \\
\text { Moderna }\end{array}$ & $\begin{array}{l}\text { Variante } \\
\text { matuta }\end{array}$ \\
\hline 408 & Pergunta de moradô & $\begin{array}{l}\text { Ispinho e Fulô / } \\
\text { Aqui tem coisa }\end{array}$ & $\begin{array}{l}\text { Décimas - Tipo } \\
\text { A }\end{array}$ & $\begin{array}{l}\text { Variante } \\
\text { matuta }\end{array}$ \\
\hline 409 & $\begin{array}{l}\text { Pergunta de um } \\
\text { analfabeto }\end{array}$ & Aqui tem coisa & Oitavas & $\begin{array}{l}\text { Variante } \\
\text { matuta }\end{array}$ \\
\hline 410 & Pesão & $\begin{array}{l}\text { Cante lá que eu } \\
\text { canto cá }\end{array}$ & $\begin{array}{l}\text { Sextilha } \\
\text { Moderna }\end{array}$ & $\begin{array}{l}\text { Norma } \\
\text { padrão }\end{array}$ \\
\hline 411 & $\begin{array}{l}\text { Pitú na segunda vida dos } \\
\text { cachorros }\end{array}$ & Aqui tem coisa & $\begin{array}{l}\text { Décimas - Tipo } \\
\text { A }\end{array}$ & $\begin{array}{l}\text { Norma } \\
\text { padrão }\end{array}$ \\
\hline 412 & Pobre Santo Antônio! & $\begin{array}{l}\text { Melhores Poemas / } \\
\text { Novos poemas } \\
\text { comentados }\end{array}$ & Quartetos & $\begin{array}{l}\text { Norma } \\
\text { padrão }\end{array}$ \\
\hline 413 & Prefeito com Prefeitura & $\begin{array}{l}\text { Melhores Poemas / } \\
\text { Balceiro } 2\end{array}$ & $\begin{array}{l}\text { Décimas - Tipo } \\
\text { A }\end{array}$ & $\begin{array}{l}\text { Norma } \\
\text { padrão }\end{array}$ \\
\hline 414 & Prefeitura sem Prefeito & $\begin{array}{l}\text { Novos poemas } \\
\text { comentados / } \\
\text { Melhores Poemas } \\
\end{array}$ & $\begin{array}{l}\text { Décimas - Tipo } \\
\text { B }\end{array}$ & $\begin{array}{l}\text { Norma } \\
\text { padrão }\end{array}$ \\
\hline 415 & Presente Dizagradave & Aqui tem coisa & $\begin{array}{l}\text { Décimas - Tipo } \\
\text { A }\end{array}$ & $\begin{array}{l}\text { Variante } \\
\text { matuta }\end{array}$ \\
\hline 416 & Prezado Amigo & Ispinho e Fulô & Soneto & $\begin{array}{l}\text { Norma } \\
\text { padrão }\end{array}$ \\
\hline 417 & $\begin{array}{l}\text { Professor J. de Figueiredo } \\
\text { Filho }\end{array}$ & $\begin{array}{l}\text { Cante lá que eu } \\
\text { canto cá }\end{array}$ & Quartetos & $\begin{array}{l}\text { Norma } \\
\text { padrão }\end{array}$ \\
\hline 418 & Proque deixei Zabé & Cante lá que eu & Décimas - Tipo & Variante \\
\hline
\end{tabular}




\begin{tabular}{|c|c|c|c|c|}
\hline & & canto cá & A & matuta \\
\hline 419 & $\begin{array}{l}\text { Quadrinha: A descoberta } \\
\text { sem par }\end{array}$ & $\begin{array}{l}\text { Novos poemas } \\
\text { comentados / } \\
\text { Melhores Poemas }\end{array}$ & Quadra & $\begin{array}{l}\text { Norma } \\
\text { padrão }\end{array}$ \\
\hline 420 & $\begin{array}{l}\text { Quadrinha: A fogueira da } \\
\text { vaidade }\end{array}$ & $\begin{array}{l}\text { Novos poemas } \\
\text { comentados / } \\
\text { Cante lá que eu } \\
\text { canto cá / Melhores } \\
\text { Poemas } \\
\end{array}$ & Quadra & $\begin{array}{l}\text { Norma } \\
\text { padrão }\end{array}$ \\
\hline 421 & $\begin{array}{l}\text { Quadrinha: A língua é tal } \\
\text { qual a faca }\end{array}$ & Ispinho e Fulô & Quadra & $\begin{array}{l}\text { Norma } \\
\text { padrão }\end{array}$ \\
\hline 422 & $\begin{array}{l}\text { Quadrinha: A lua foi a } \\
\text { ilusão }\end{array}$ & Ispinho e Fulô & Quadra & $\begin{array}{l}\text { Norma } \\
\text { padrão }\end{array}$ \\
\hline 423 & $\begin{array}{l}\text { Quadrinha: A mentira } \\
\text { sem escala }\end{array}$ & $\begin{array}{l}\text { Inspiração } \\
\text { nordestina }\end{array}$ & Quadra & $\begin{array}{l}\text { Norma } \\
\text { padrão }\end{array}$ \\
\hline 424 & $\begin{array}{l}\text { Quadrinha: A mim não } \\
\text { faltará nada }\end{array}$ & $\begin{array}{l}\text { Inspiração } \\
\text { nordestina }\end{array}$ & Quadra & $\begin{array}{l}\text { Norma } \\
\text { padrão }\end{array}$ \\
\hline 425 & $\begin{array}{l}\text { Quadrinha: A moléstia } \\
\text { mais horrível }\end{array}$ & $\begin{array}{l}\text { Inspiração } \\
\text { nordestina / Cante } \\
\text { lá que eu canto cá }\end{array}$ & Quadra & $\begin{array}{l}\text { Norma } \\
\text { padrão }\end{array}$ \\
\hline 426 & $\begin{array}{l}\text { Quadrinha: A mulher } \\
\text { também tem isca }\end{array}$ & $\begin{array}{l}\text { Novos poemas } \\
\text { comentados / } \\
\text { Ispinho e Fulô / } \\
\text { Melhores Poemas }\end{array}$ & Quadra & $\begin{array}{l}\text { Norma } \\
\text { padrão }\end{array}$ \\
\hline 427 & $\begin{array}{l}\text { Quadrinha: A natureza } \\
\text { por capricho } 79\end{array}$ & $\begin{array}{l}\text { Novos poemas } \\
\text { comentados / } \\
\text { Cante lá que eu } \\
\text { canto cá / Melhores } \\
\text { Poemas }\end{array}$ & Quadra & $\begin{array}{l}\text { Norma } \\
\text { padrão }\end{array}$ \\
\hline 428 & $\begin{array}{l}\text { Quadrinha: A rosa do } \\
\text { meu ciúme }\end{array}$ & Ispinho e Fulô & Quadra & $\begin{array}{l}\text { Norma } \\
\text { padrão }\end{array}$ \\
\hline 429 & $\begin{array}{l}\text { Quadrinha: Acho melhor } \\
\text { ser amado }\end{array}$ & $\begin{array}{l}\text { Inspiração } \\
\text { nordestina / Cante } \\
\text { lá que eu canto cá }\end{array}$ & Quadra & $\begin{array}{l}\text { Norma } \\
\text { padrão }\end{array}$ \\
\hline 430 & $\begin{array}{l}\text { Quadrinha: Ao amor } \\
\text { nasci propenso }\end{array}$ & $\begin{array}{l}\text { Novos poemas } \\
\text { comentados / } \\
\text { Ispinho e Fulô / } \\
\text { Melhores Poemas }\end{array}$ & Quadra & $\begin{array}{l}\text { Norma } \\
\text { padrão }\end{array}$ \\
\hline 431 & $\begin{array}{l}\text { Quadrinha: Cada qual na } \\
\text { sua lida }\end{array}$ & Ispinho e Fulô & Quadra & $\begin{array}{l}\text { Norma } \\
\text { padrão }\end{array}$ \\
\hline 432 & $\begin{array}{l}\text { Quadrinha: Cada um } \\
\text { alegre vai }\end{array}$ & $\begin{array}{l}\text { Inspiração } \\
\text { nordestina / Cante } \\
\text { lá que eu canto cá }\end{array}$ & Quadra & $\begin{array}{l}\text { Norma } \\
\text { padrão }\end{array}$ \\
\hline 433 & $\begin{array}{l}\text { Quadrinha: Cada um no } \\
\text { mundo vai }\end{array}$ & $\begin{array}{l}\text { Inspiração } \\
\text { nordestina }\end{array}$ & Quadra & $\begin{array}{l}\text { Norma } \\
\text { padrão }\end{array}$ \\
\hline 434 & Quadrinha: Casamento é & Inspiração & Quadra & Norma \\
\hline
\end{tabular}

\footnotetext{
79 “A natura, por capricho,". In: Cante lá que eu canto cá (1978 e 2014), Melhores poemas (2006) e Novos poemas comentados (1970).
} 


\begin{tabular}{|c|c|c|c|c|}
\hline & um engenho & $\begin{array}{l}\text { nordestina / Cante } \\
\text { lá que eu canto cá }\end{array}$ & & padrão \\
\hline 435 & $\begin{array}{l}\text { Quadrinha: Casamento é } \\
\text { um problema }\end{array}$ & $\begin{array}{l}\text { Novos poemas } \\
\text { comentados / } \\
\text { Melhores Poemas }\end{array}$ & Quadra & $\begin{array}{l}\text { Norma } \\
\text { padrão }\end{array}$ \\
\hline 436 & $\begin{array}{l}\text { Quadrinha: Com a luz do } \\
\text { teu olhar }\end{array}$ & $\begin{array}{l}\text { Inspiração } \\
\text { nordestina / } \\
\text { Ispinho e Fulô }\end{array}$ & Quadra & $\begin{array}{l}\text { Norma } \\
\text { padrão }\end{array}$ \\
\hline 437 & $\begin{array}{l}\text { Quadrinha: Com três } \\
\text { meninas, meu fado }\end{array}$ & $\begin{array}{l}\text { Novos poemas } \\
\text { comentados / } \\
\text { Ispinho e Fulô / } \\
\text { Melhores Poemas }\end{array}$ & Quadra & $\begin{array}{l}\text { Norma } \\
\text { padrão }\end{array}$ \\
\hline 438 & $\begin{array}{l}\text { Quadrinha: Como é que } \\
\text { amor verdadeiro }\end{array}$ & Ispinho e Fulô & Quadra & $\begin{array}{l}\text { Norma } \\
\text { padrão }\end{array}$ \\
\hline 439 & $\begin{array}{l}\text { Quadrinha: Como é que } \\
\text { me diz um lente }\end{array}$ & $\begin{array}{l}\text { Inspiração } \\
\text { nordestina / Cante } \\
\text { lá que eu canto cá }\end{array}$ & Quadra & $\begin{array}{l}\text { Norma } \\
\text { padrão }\end{array}$ \\
\hline 440 & $\begin{array}{l}\text { Quadrinha: Corrente de } \\
\text { grossas águas }\end{array}$ & Ispinho e Fulô & Quadra & $\begin{array}{l}\text { Norma } \\
\text { padrão }\end{array}$ \\
\hline 441 & $\begin{array}{l}\text { Quadrinha: Daria as } \\
\text { estrelas belas }\end{array}$ & $\begin{array}{l}\text { Inspiração } \\
\text { nordestina }\end{array}$ & Quadra & $\begin{array}{l}\text { Norma } \\
\text { padrão }\end{array}$ \\
\hline 442 & $\begin{array}{l}\text { Quadrinha: Desde o dia } \\
\text { de tristeza }\end{array}$ & $\begin{array}{l}\text { Novos poemas } \\
\text { comentados / } \\
\text { Ispinho e Fulô / } \\
\text { Melhores Poemas }\end{array}$ & Quadra & $\begin{array}{l}\text { Norma } \\
\text { padrão }\end{array}$ \\
\hline 443 & $\begin{array}{l}\text { Quadrinha: Desde o dia } \\
\text { em que partiste }\end{array}$ & $\begin{array}{l}\text { Inspiração } \\
\text { nordestina / } \\
\text { Ispinho e Fulô }\end{array}$ & Quadra & $\begin{array}{l}\text { Norma } \\
\text { padrão }\end{array}$ \\
\hline 444 & $\begin{array}{l}\text { Quadrinha: Dois ferrões } \\
\text { de marimbondo }\end{array}$ & $\begin{array}{l}\text { Cante lá que eu } \\
\text { canto cá }\end{array}$ & Quadra & $\begin{array}{l}\text { Norma } \\
\text { padrão }\end{array}$ \\
\hline 445 & $\begin{array}{l}\text { Quadrinha: Em um } \\
\text { jardim eu entrei }\end{array}$ & $\begin{array}{l}\text { Inspiração } \\
\text { nordestina / } \\
\text { Ispinho e Fulô }\end{array}$ & Quadra & $\begin{array}{l}\text { Norma } \\
\text { padrão }\end{array}$ \\
\hline 446 & $\begin{array}{l}\text { Quadrinha: Em paga da } \\
\text { ofensa infinda }\end{array}$ & $\begin{array}{l}\text { Inspiração } \\
\text { nordestina }\end{array}$ & Quadra & $\begin{array}{l}\text { Norma } \\
\text { padrão }\end{array}$ \\
\hline 447 & $\begin{array}{l}\text { Quadrinha: Enquanto a } \\
\text { escada dos bons }\end{array}$ & $\begin{array}{l}\text { Inspiração } \\
\text { nordestina }\end{array}$ & Quadra & $\begin{array}{l}\text { Norma } \\
\text { padrão }\end{array}$ \\
\hline 448 & $\begin{array}{l}\text { Quadrinha: Entre as } \\
\text { mulheres cacei }\end{array}$ & $\begin{array}{l}\text { Novos poemas } \\
\text { comentados / } \\
\text { Cante lá que eu } \\
\text { canto cá / Melhores } \\
\text { Poemas }\end{array}$ & Quadra & $\begin{array}{l}\text { Norma } \\
\text { padrão }\end{array}$ \\
\hline 449 & $\begin{array}{l}\text { Quadrinha: Esta ciência } \\
\text { sem par }\end{array}$ & $\begin{array}{l}\text { Novos poemas } \\
\text { comentados / } \\
\text { Cante lá que eu } \\
\text { canto cá / Melhores } \\
\text { Poemas }\end{array}$ & Quadra & $\begin{array}{l}\text { Norma } \\
\text { padrão }\end{array}$ \\
\hline 450 & $\begin{array}{l}\text { Quadrinha: Há entre mim } \\
\text { e a mulher }\end{array}$ & $\begin{array}{l}\text { Inspiração } \\
\text { nordestina }\end{array}$ & Quadra & $\begin{array}{l}\text { Norma } \\
\text { padrão }\end{array}$ \\
\hline
\end{tabular}




\begin{tabular}{|c|c|c|c|c|}
\hline 451 & $\begin{array}{l}\text { Quadrinha: Há coisa que } \\
\text { a gente arrisca }\end{array}$ & $\begin{array}{l}\text { Inspiração } \\
\text { nordestina / Cante } \\
\text { lá que eu canto cá }\end{array}$ & Quadra & $\begin{array}{l}\text { Norma } \\
\text { padrão }\end{array}$ \\
\hline 452 & $\begin{array}{l}\text { Quadrinha: Me negaste o } \\
\text { teu carinho }\end{array}$ & $\begin{array}{l}\text { Novos poemas } \\
\text { comentados / } \\
\text { Melhores Poemas }\end{array}$ & Quadra & $\begin{array}{l}\text { Norma } \\
\text { padrão }\end{array}$ \\
\hline 453 & $\begin{array}{l}\text { Quadrinha: Mesmo a mãe } \\
\text { dando gemido }\end{array}$ & Ispinho e Fulô & Quadra & $\begin{array}{l}\text { Norma } \\
\text { padrão }\end{array}$ \\
\hline 454 & $\begin{array}{l}\text { Quadrinha: Mesmo com } \\
\text { censura grave }\end{array}$ & $\begin{array}{l}\text { Cante lá que eu } \\
\text { canto cá }\end{array}$ & Quadra & $\begin{array}{l}\text { Norma } \\
\text { padrão }\end{array}$ \\
\hline 455 & $\begin{array}{l}\text { Quadrinha: Meu } \\
\text { benzinho interesseiro }\end{array}$ & $\begin{array}{l}\text { Novos poemas } \\
\text { comentados / } \\
\text { Melhores Poemas }\end{array}$ & Quadra & $\begin{array}{l}\text { Norma } \\
\text { padrão }\end{array}$ \\
\hline 456 & $\begin{array}{l}\text { Quadrinha: Minha viola } \\
\text { de estima }\end{array}$ & $\begin{array}{l}\text { Inspiração } \\
\text { nordestina }\end{array}$ & Quadra & $\begin{array}{l}\text { Norma } \\
\text { padrão }\end{array}$ \\
\hline 457 & $\begin{array}{l}\text { Quadrinha: Morena você } \\
\text { me deixe }\end{array}$ & Ispinho e Fulô & Quadra & $\begin{array}{l}\text { Norma } \\
\text { padrão }\end{array}$ \\
\hline 458 & $\begin{array}{l}\text { Quadrinha: Moreninha, o } \\
\text { meu desejo }\end{array}$ & $\begin{array}{l}\text { Inspiração } \\
\text { nordestina / Cante } \\
\text { lá que eu canto cá / } \\
\text { Melhores Poemas }\end{array}$ & Quadra & $\begin{array}{l}\text { Norma } \\
\text { padrão }\end{array}$ \\
\hline 459 & $\begin{array}{l}\text { Quadrinha: Muito faz } \\
\text { aborrecer }\end{array}$ & $\begin{array}{l}\text { Novos poemas } \\
\text { comentados / } \\
\text { Melhores Poemas }\end{array}$ & Quadra & $\begin{array}{l}\text { Norma } \\
\text { padrão }\end{array}$ \\
\hline 460 & $\begin{array}{l}\text { Quadrinha: Mulher, saúde } \\
\text { e dinheiro }\end{array}$ & $\begin{array}{l}\text { Inspiração } \\
\text { nordestina }\end{array}$ & Quadra & $\begin{array}{l}\text { Norma } \\
\text { padrão }\end{array}$ \\
\hline 461 & $\begin{array}{l}\text { Quadrinha: Na mulher } \\
\text { sempre diviso }\end{array}$ & $\begin{array}{l}\text { Inspiração } \\
\text { nordestina / Cante } \\
\text { lá que eu canto cá }\end{array}$ & Quadra & $\begin{array}{l}\text { Norma } \\
\text { padrão }\end{array}$ \\
\hline 462 & $\begin{array}{l}\text { Quadrinha: Na vida o que } \\
\text { não quero }\end{array}$ & $\begin{array}{l}\text { Inspiração } \\
\text { nordestina / Cante } \\
\text { lá que eu canto cá }\end{array}$ & Quadra & $\begin{array}{l}\text { Norma } \\
\text { padrão }\end{array}$ \\
\hline 463 & $\begin{array}{l}\text { Quadrinha: Não farei o } \\
\text { teu desejo }\end{array}$ & $\begin{array}{l}\text { Novos poemas } \\
\text { comentados / } \\
\text { Cante lá que eu } \\
\text { canto cá / Melhores } \\
\text { Poemas } \\
\end{array}$ & Quadra & $\begin{array}{l}\text { Norma } \\
\text { padrão }\end{array}$ \\
\hline 464 & $\begin{array}{l}\text { Quadrinha: Naquele belo } \\
\text { ambiente }\end{array}$ & Ispinho e Fulô & Quadra & $\begin{array}{l}\text { Norma } \\
\text { padrão }\end{array}$ \\
\hline 465 & $\begin{array}{l}\text { Quadrinha: Nas minhas } \\
\text { dores sem fim }\end{array}$ & $\begin{array}{l}\text { Inspiração } \\
\text { nordestina }\end{array}$ & Quadra & $\begin{array}{l}\text { Norma } \\
\text { padrão }\end{array}$ \\
\hline 466 & $\begin{array}{l}\text { Quadrinha: Neste meu } \\
\text { pinho adorado }\end{array}$ & $\begin{array}{l}\text { Inspiração } \\
\text { nordestina }\end{array}$ & Quadra & $\begin{array}{l}\text { Norma } \\
\text { padrão }\end{array}$ \\
\hline 467 & $\begin{array}{l}\text { Quadrinha: No nosso } \\
\text { peito a ilusão }\end{array}$ & $\begin{array}{l}\text { Inspiração } \\
\text { nordestina }\end{array}$ & Quadra & $\begin{array}{l}\text { Norma } \\
\text { padrão }\end{array}$ \\
\hline 468 & $\begin{array}{l}\text { Quadrinha: O mundo está } \\
\text { sempre cheio }\end{array}$ & $\begin{array}{l}\text { Inspiração } \\
\text { nordestina / Cante } \\
\text { lá que eu canto cá }\end{array}$ & Quadra & $\begin{array}{l}\text { Norma } \\
\text { padrão }\end{array}$ \\
\hline 469 & Quadrinha: O poeta é um & Inspiração & Quadra & Norma \\
\hline
\end{tabular}




\begin{tabular}{|c|c|c|c|c|}
\hline & vagabundo & nordestina & & padrão \\
\hline 470 & $\begin{array}{l}\text { Quadrinha: O que o olhar } \\
\text { não avista }\end{array}$ & $\begin{array}{l}\text { Cante lá que eu } \\
\text { canto cá }\end{array}$ & Quadra & $\begin{array}{l}\text { Norma } \\
\text { padrão }\end{array}$ \\
\hline 471 & $\begin{array}{l}\text { Quadrinha: O quê, } \\
\text { palavra mesquinha }\end{array}$ & $\begin{array}{l}\text { Novos poemas } \\
\text { comentados / } \\
\text { Melhores Poemas }\end{array}$ & Quadra & $\begin{array}{l}\text { Norma } \\
\text { padrão }\end{array}$ \\
\hline 472 & $\begin{array}{l}\text { Quadrinha: Por uma } \\
\text { casualidade }\end{array}$ & $\begin{array}{l}\text { Novos poemas } \\
\text { comentados / } \\
\text { Cante lá que eu } \\
\text { canto cá / Melhores } \\
\text { Poemas }\end{array}$ & Quadra & $\begin{array}{l}\text { Norma } \\
\text { padrão }\end{array}$ \\
\hline 473 & $\begin{array}{l}\text { Quadrinha: Pra gente } \\
\text { saber que é besta }\end{array}$ & Ispinho e Fulô & Quadra & $\begin{array}{l}\text { Norma } \\
\text { padrão }\end{array}$ \\
\hline 474 & $\begin{array}{l}\text { Quadrinha: Quando a } \\
\text { mentira surgiu }\end{array}$ & $\begin{array}{l}\text { Inspiração } \\
\text { nordestina }\end{array}$ & Quadra & $\begin{array}{l}\text { Norma } \\
\text { padrão }\end{array}$ \\
\hline 475 & $\begin{array}{l}\text { Quadrinha: Quando eu te } \\
\text { vejo, Maria, }\end{array}$ & Ispinho e Fulô & Quadra & $\begin{array}{l}\text { Norma } \\
\text { padrão }\end{array}$ \\
\hline 476 & $\begin{array}{l}\text { Quadrinha: Quando o } \\
\text { amor não é fiel }\end{array}$ & Ispinho e Fulô & Quadra & $\begin{array}{l}\text { Norma } \\
\text { padrão }\end{array}$ \\
\hline 477 & $\begin{array}{l}\text { Quadrinha: Quando } \\
\text { raivosa te exaltas }\end{array}$ & $\begin{array}{l}\text { Novos poemas } \\
\text { comentados / } \\
\text { Cante lá que eu } \\
\text { canto cá / Melhores } \\
\text { Poemas }\end{array}$ & Quadra & $\begin{array}{l}\text { Norma } \\
\text { padrão }\end{array}$ \\
\hline 478 & $\begin{array}{l}\text { Quadrinha: Que alguém } \\
\text { morre por alguém }\end{array}$ & $\begin{array}{l}\text { Novos poemas } \\
\text { comentados / } \\
\text { Ispinho e Fulô / } \\
\text { Melhores Poemas }\end{array}$ & Quadra & $\begin{array}{l}\text { Norma } \\
\text { padrão }\end{array}$ \\
\hline 479 & $\begin{array}{l}\text { Quadrinha: Quem mais } \\
\text { bate é o coração }\end{array}$ & $\begin{array}{l}\text { Novos poemas } \\
\text { comentados / } \\
\text { Melhores Poemas } \\
\end{array}$ & Quadra & $\begin{array}{l}\text { Norma } \\
\text { padrão }\end{array}$ \\
\hline 480 & $\begin{array}{l}\text { Quadrinha: Se aquieta, } \\
\text { não seja louca }\end{array}$ & $\begin{array}{l}\text { Novos poemas } \\
\text { comentados / } \\
\text { Melhores Poemas }\end{array}$ & Quadra & $\begin{array}{l}\text { Norma } \\
\text { padrão }\end{array}$ \\
\hline 481 & $\begin{array}{l}\text { Quadrinha: Se o orgulho } \\
\text { e a hipocrisia }\end{array}$ & $\begin{array}{l}\text { Inspiração } \\
\text { nordestina / Cante } \\
\text { lá que eu canto cá }\end{array}$ & Quadra & $\begin{array}{l}\text { Norma } \\
\text { padrão }\end{array}$ \\
\hline 482 & $\begin{array}{l}\text { Quadrinha: Segue o } \\
\text { tempo o seu caminho }\end{array}$ & $\begin{array}{l}\text { Novos poemas } \\
\text { comentados / } \\
\text { Cante lá que eu } \\
\text { canto cá / Melhores } \\
\text { Poemas }\end{array}$ & Quadra & $\begin{array}{l}\text { Norma } \\
\text { padrão }\end{array}$ \\
\hline 483 & $\begin{array}{l}\text { Quadrinha: Sempre } \\
\text { satisfeito estou }\end{array}$ & Ispinho e Fulô & Quadra & $\begin{array}{l}\text { Norma } \\
\text { padrão }\end{array}$ \\
\hline 484 & $\begin{array}{l}\text { Quadrinha: Ser poeta é } \\
\text { ter paixão }\end{array}$ & $\begin{array}{l}\text { Novos poemas } \\
\text { comentados / } \\
\text { Cante lá que eu } \\
\text { canto cá / Melhores } \\
\text { Poemas }\end{array}$ & Quadra & $\begin{array}{l}\text { Norma } \\
\text { padrão }\end{array}$ \\
\hline
\end{tabular}




\begin{tabular}{|c|c|c|c|c|}
\hline 485 & $\begin{array}{l}\text { Quadrinha: Ser trovador é } \\
\text { ser louco }\end{array}$ & $\begin{array}{l}\text { Inspiração } \\
\text { nordestina }\end{array}$ & Quadra & $\begin{array}{l}\text { Norma } \\
\text { padrão }\end{array}$ \\
\hline 486 & $\begin{array}{l}\text { Quadrinha: Seria bem } \\
\text { triste a sorte }\end{array}$ & $\begin{array}{l}\text { Inspiração } \\
\text { nordestina / Cante } \\
\text { lá que eu canto cá }\end{array}$ & Quadra & $\begin{array}{l}\text { Norma } \\
\text { padrão }\end{array}$ \\
\hline 487 & $\begin{array}{l}\text { Quadrinha: Somente o } \\
\text { rico na terra }\end{array}$ & $\begin{array}{l}\text { Inspiração } \\
\text { nordestina / Cante } \\
\text { lá que eu canto cá }\end{array}$ & Quadra & $\begin{array}{l}\text { Norma } \\
\text { padrão }\end{array}$ \\
\hline 488 & $\begin{array}{l}\text { Quadrinha: Toda a } \\
\text { natureza cheia }\end{array}$ & Ispinho e Fulô & Quadra & $\begin{array}{l}\text { Norma } \\
\text { padrão }\end{array}$ \\
\hline 489 & $\begin{array}{l}\text { Quadrinha: Você que } \\
\text { passa grã-fina }\end{array}$ & $\begin{array}{l}\text { Novos poemas } \\
\text { comentados / } \\
\text { Ispinho e fulo / } \\
\text { Melhores Poemas }\end{array}$ & Quadra & $\begin{array}{l}\text { Norma } \\
\text { padrão }\end{array}$ \\
\hline 490 & Quem é esta mulher? & Aqui tem coisa & Quartetos & $\begin{array}{l}\text { Norma } \\
\text { padrão }\end{array}$ \\
\hline 491 & Raimundo Jacó & Ispinho e Fulô & $\begin{array}{l}\text { Décimas - Tipo } \\
\text { A }\end{array}$ & $\begin{array}{l}\text { Norma } \\
\text { padrão }\end{array}$ \\
\hline 492 & Reforma Agrara é Assim & Aqui tem coisa & $\begin{array}{l}\text { Décimas - Tipo } \\
\text { A }\end{array}$ & $\begin{array}{l}\text { Variante } \\
\text { matuta }\end{array}$ \\
\hline 493 & Reforma Agrária & Ispinho e Fulô & Soneto & $\begin{array}{l}\text { Norma } \\
\text { padrão }\end{array}$ \\
\hline 494 & $\begin{array}{l}\text { Resposta ao meu amigo e } \\
\text { colega José Helder } \\
\text { França (Dedé) }\end{array}$ & $\begin{array}{l}\text { Cante lá que eu } \\
\text { canto cá }\end{array}$ & $\begin{array}{l}\text { Décimas - Tipo } \\
\text { A }\end{array}$ & $\begin{array}{l}\text { Norma } \\
\text { padrão }\end{array}$ \\
\hline 495 & Resposta de Patrão ${ }^{80}$ & $\begin{array}{l}\text { Ispinho e Fulô / } \\
\text { Aqui tem coisa }\end{array}$ & $\begin{array}{l}\text { Décimas - Tipo } \\
\text { A }\end{array}$ & $\begin{array}{l}\text { Norma } \\
\text { padrão }\end{array}$ \\
\hline 496 & $\begin{array}{l}\text { Resposta do Patativa ao } \\
\text { Padre Vieira }\end{array}$ & Ispinho e Fulô & $\begin{array}{l}\text { Décimas - Tipo } \\
\text { A }\end{array}$ & $\begin{array}{l}\text { Norma } \\
\text { padrão }\end{array}$ \\
\hline 497 & Rogaciano Leite & $\begin{array}{l}\text { Cante lá que eu } \\
\text { canto cá / Novos } \\
\text { poemas } \\
\text { comentados }\end{array}$ & $\begin{array}{l}\text { Décimas - Tipo } \\
\text { A }\end{array}$ & $\begin{array}{l}\text { Norma } \\
\text { padrão }\end{array}$ \\
\hline 498 & Rogando Praga $^{81}$ & $\begin{array}{l}\text { Ispinho e Fulô / } \\
\text { Cordel / Novos } \\
\text { poemas } \\
\text { comentados }\end{array}$ & $\begin{array}{l}\text { Décimas - Tipo } \\
\text { B }\end{array}$ & $\begin{array}{l}\text { Norma } \\
\text { padrão }\end{array}$ \\
\hline 499 & Rosa e Rosinha & Ispinho e Fulô & Quartetos & $\begin{array}{l}\text { Norma } \\
\text { padrão }\end{array}$ \\
\hline 500 & Saudação ao ano 2000 & $\begin{array}{l}\text { Melhores Poemas / } \\
\text { Balceiro } 2\end{array}$ & $\begin{array}{l}\text { Sextilha } \\
\text { Moderna }\end{array}$ & $\begin{array}{l}\text { Norma } \\
\text { padrão }\end{array}$ \\
\hline 501 & $\begin{array}{l}\text { Saudação ao Juazeiro do } \\
\text { Norte }\end{array}$ & $\begin{array}{l}\text { Inspiração } \\
\text { nordestina / } \\
\text { Ispinho e Fulô / }\end{array}$ & $\begin{array}{l}\text { Décimas - Tipo } \\
\text { A }\end{array}$ & $\begin{array}{l}\text { Norma } \\
\text { padrão }\end{array}$ \\
\hline
\end{tabular}

80 "Resposta do patrão". In: Aqui tem coisa (2005).

81 "Rogando pragas". In: Cordéis. (2012). 


\begin{tabular}{|c|c|c|c|c|}
\hline & & Cordel & & \\
\hline 502 & Saudade & Ispinho e Fulô & Quartetos & $\begin{array}{l}\text { Norma } \\
\text { padrão }\end{array}$ \\
\hline 503 & Se existe inferno & $\begin{array}{l}\text { Inspiração } \\
\text { nordestina / Cante } \\
\text { lá que eu canto cá }\end{array}$ & Quartetos & $\begin{array}{l}\text { Norma } \\
\text { padrão }\end{array}$ \\
\hline 504 & Seca D'Água & Ispinho e Fulô & $\begin{array}{l}\text { Mistas: sext.e } \\
\text { quadra }\end{array}$ & $\begin{array}{l}\text { Norma } \\
\text { padrão }\end{array}$ \\
\hline 505 & Ser Feliz & $\begin{array}{l}\text { Inspiração } \\
\text { nordestina / Cante } \\
\text { lá que eu canto cá / } \\
\text { Melhores Poemas }\end{array}$ & Oitavas & $\begin{array}{l}\text { Norma } \\
\text { padrão }\end{array}$ \\
\hline 506 & Serra de Santana & $\begin{array}{l}\text { Cante lá que eu } \\
\text { canto cá }\end{array}$ & $\begin{array}{l}\text { Décimas - Tipo } \\
\text { A }\end{array}$ & $\begin{array}{l}\text { Variante } \\
\text { matuta }\end{array}$ \\
\hline 507 & Seu Dotô me Conhece? & $\begin{array}{l}\text { Inspiração } \\
\text { nordestina / Cante } \\
\text { lá que eu canto cá }\end{array}$ & $\begin{array}{l}\text { Sextilha } \\
\text { Moderna }\end{array}$ & $\begin{array}{l}\text { Variante } \\
\text { matuta }\end{array}$ \\
\hline 508 & $\begin{array}{l}\text { Sodade é assim - Ao } \\
\text { jornalista Antônio } \\
\text { Vicelmo }\end{array}$ & $\begin{array}{l}\text { Cante lá que eu } \\
\text { canto cá }\end{array}$ & $\begin{array}{l}\text { Décimas - Tipo } \\
\text { A }\end{array}$ & $\begin{array}{l}\text { Variante } \\
\text { matuta }\end{array}$ \\
\hline 509 & Soneto de Patativa & Balceiro 2 & Soneto & $\begin{array}{l}\text { Norma } \\
\text { padrão }\end{array}$ \\
\hline 510 & Sonho Agradável & Cordéis & Sextilha Cordel & $\begin{array}{l}\text { Norma } \\
\text { padrão }\end{array}$ \\
\hline 511 & Sou cabra da peste & $\begin{array}{l}\text { Cante lá que eu } \\
\text { canto cá / Melhores } \\
\text { Poemas / Novos } \\
\text { poemas } \\
\text { comentados }\end{array}$ & Quartetos & $\begin{array}{l}\text { Variante } \\
\text { matuta }\end{array}$ \\
\hline 512 & Sou nordestino & Aqui tem coisa & $\begin{array}{l}\text { Mistas: Sex. e } \\
\text { oitava }\end{array}$ & $\begin{array}{l}\text { Norma } \\
\text { padrão }\end{array}$ \\
\hline 513 & Suzana Bela & Aqui tem coisa & Quartetos & $\begin{array}{l}\text { Norma } \\
\text { padrão }\end{array}$ \\
\hline 514 & Teia de Aranha & $\begin{array}{l}\text { Balceiro / } \\
\text { Melhores Poemas }\end{array}$ & $\begin{array}{l}\text { Sextilha } \\
\text { Moderna }\end{array}$ & $\begin{array}{l}\text { Norma } \\
\text { padrão }\end{array}$ \\
\hline 515 & Tereza Potó & Ispinho e Fulô & Irregulares & $\begin{array}{l}\text { Variante } \\
\text { matuta }\end{array}$ \\
\hline 516 & Três Beijos & Ispinho e Fulô & $\begin{array}{l}\text { Décimas - Tipo } \\
\text { A }\end{array}$ & $\begin{array}{l}\text { Norma } \\
\text { padrão }\end{array}$ \\
\hline 517 & Três Moça & Ispinho e Fulô & Quartetos & $\begin{array}{l}\text { Variante } \\
\text { matuta }\end{array}$ \\
\hline 518 & Treze de Agosto & $\begin{array}{l}\text { Cante lá que eu } \\
\text { canto cá }\end{array}$ & Soneto & $\begin{array}{l}\text { Norma } \\
\text { padrão }\end{array}$ \\
\hline 519 & Tudinha & $\begin{array}{l}\text { Cante lá que eu } \\
\text { canto cá }\end{array}$ & $\begin{array}{l}\text { Sextilha } \\
\text { Moderna }\end{array}$ & $\begin{array}{l}\text { Variante } \\
\text { matuta }\end{array}$ \\
\hline 520 & $\begin{array}{l}\text { Um Candidato na Casa de } \\
\text { um Caçador }\end{array}$ & Ispinho e Fulô & $\begin{array}{l}\text { Décimas - Tipo } \\
\text { C }\end{array}$ & $\begin{array}{l}\text { Variante } \\
\text { matuta }\end{array}$ \\
\hline
\end{tabular}




\begin{tabular}{|c|c|c|c|c|}
\hline 521 & Um cearense desterrado & Ispinho e Fulô & $\begin{array}{l}\text { Décimas - Tipo } \\
\text { A }\end{array}$ & $\begin{array}{l}\text { Variante } \\
\text { matuta }\end{array}$ \\
\hline 522 & Um Grande Poeta & $\begin{array}{l}\text { Balceiro / } \\
\text { Melhores Poemas }\end{array}$ & Soneto & $\begin{array}{l}\text { Norma } \\
\text { padrão }\end{array}$ \\
\hline 523 & $\begin{array}{l}\text { Um grande poeta } \\
\text { embriagado }\end{array}$ & $\begin{array}{l}\text { Novos poemas } \\
\text { comentados }\end{array}$ & $\begin{array}{l}\text { Décimas - Tipo } \\
\text { A }\end{array}$ & $\begin{array}{l}\text { Norma } \\
\text { padrão }\end{array}$ \\
\hline 524 & Um mundo desconhecido & $\begin{array}{l}\text { Melhores Poemas / } \\
\text { Balceiro } 2\end{array}$ & $\begin{array}{l}\text { Décimas - Tipo } \\
\text { B }\end{array}$ & $\begin{array}{l}\text { Norma } \\
\text { padrão }\end{array}$ \\
\hline 525 & Um Sabiá Vaidoso & $\begin{array}{l}\text { Aqui tem coisa / } \\
\text { Melhores Poemas }\end{array}$ & $\begin{array}{l}\text { Mistas: quadra e } \\
\text { sex }\end{array}$ & $\begin{array}{l}\text { Norma } \\
\text { padrão }\end{array}$ \\
\hline 526 & Um Sonho Desfeito & Ispinho e Fulô & $\begin{array}{l}\text { Décimas - Tipo } \\
\text { A }\end{array}$ & $\begin{array}{l}\text { Norma } \\
\text { padrão }\end{array}$ \\
\hline 527 & Uma do diabo & $\begin{array}{l}\text { Inspiração } \\
\text { nordestina }\end{array}$ & $\begin{array}{l}\text { Décimas - Tipo } \\
\text { A }\end{array}$ & $\begin{array}{l}\text { Variante } \\
\text { matuta }\end{array}$ \\
\hline 528 & Uma Triste Verdade & $\begin{array}{l}\text { Inspiração } \\
\text { nordestina / Cante } \\
\text { lá que eu canto cá }\end{array}$ & $\begin{array}{l}\text { Sextilha } \\
\text { Composta }\end{array}$ & $\begin{array}{l}\text { Variante } \\
\text { matuta }\end{array}$ \\
\hline 529 & Vaca Estrela e Boi Fubá & $\begin{array}{l}\text { Cante lá que eu } \\
\text { canto cá / Melhores } \\
\text { Poemas }\end{array}$ & $\begin{array}{l}\text { Mista: Décima e } \\
\text { refrão }\end{array}$ & $\begin{array}{l}\text { Variante } \\
\text { matuta }\end{array}$ \\
\hline 530 & Vaca Lavandeira & $\begin{array}{l}\text { Cante lá que eu } \\
\text { canto cá / Melhores } \\
\text { Poemas / Novos } \\
\text { poemas } \\
\text { comentados }\end{array}$ & Sextilha Cordel & $\begin{array}{l}\text { Norma } \\
\text { padrão }\end{array}$ \\
\hline 531 & Versos do Patativa & Melhores Poemas & $\begin{array}{l}\text { Décimas - Tipo } \\
\text { A }\end{array}$ & $\begin{array}{l}\text { Norma } \\
\text { padrão }\end{array}$ \\
\hline 532 & Versos Espalhafatosos & Aqui tem coisa & $\begin{array}{l}\text { Décimas - Tipo } \\
\text { A }\end{array}$ & $\begin{array}{l}\text { Variante } \\
\text { matuta }\end{array}$ \\
\hline 533 & $\begin{array}{l}\text { Vicença e Sofia ou o } \\
\text { castigo de mamãe }\end{array}$ & $\begin{array}{l}\text { Ispinho e Fulô / } \\
\text { Melhores Poemas / } \\
\text { Cordel }\end{array}$ & $\begin{array}{l}\text { Décimas - Tipo } \\
\text { A }\end{array}$ & $\begin{array}{l}\text { Variante } \\
\text { matuta }\end{array}$ \\
\hline 534 & Vida Sertaneja & $\begin{array}{l}\text { Cante lá que eu } \\
\text { canto cá / Melhores } \\
\text { Poemas / Novos } \\
\text { poemas } \\
\text { comentados }\end{array}$ & $\begin{array}{l}\text { Décimas - Tipo } \\
\text { A }\end{array}$ & $\begin{array}{l}\text { Variante } \\
\text { matuta }\end{array}$ \\
\hline 535 & Vingança de Matuto & $\begin{array}{l}\text { Novos poemas } \\
\text { comentados / } \\
\text { Cante lá que eu } \\
\text { canto cá / Melhores } \\
\text { Poemas }\end{array}$ & Quartetos & $\begin{array}{l}\text { Variante } \\
\text { matuta }\end{array}$ \\
\hline 536 & $\begin{array}{l}\text { Vive Doidinha a procurar } \\
\text { marido }\end{array}$ & $\begin{array}{l}\text { Melhores Poemas / } \\
\text { Ao pé da mesa }\end{array}$ & Soneto & $\begin{array}{l}\text { Norma } \\
\text { padrão }\end{array}$ \\
\hline 537 & 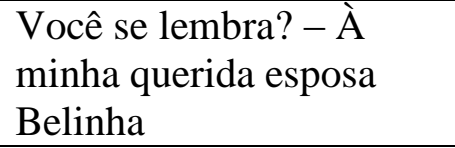 & $\begin{array}{l}\text { Cante lá que eu } \\
\text { canto cá / Melhores } \\
\text { Poemas }\end{array}$ & Quartetos & $\begin{array}{l}\text { Norma } \\
\text { padrão }\end{array}$ \\
\hline
\end{tabular}




\begin{tabular}{|c|c|c|c|c|}
\hline 538 & $\begin{array}{l}\text { Vou casar sem saber } \\
\text { quem é }\end{array}$ & $\begin{array}{l}\text { Melhores Poemas / } \\
\text { Ao pé da mesa }\end{array}$ & Soneto & $\begin{array}{l}\text { Norma } \\
\text { padrão }\end{array}$ \\
\hline 539 & Vou Vortá & $\begin{array}{l}\text { Inspiração } \\
\text { nordestina / Cante } \\
\text { lá que eu canto cá }\end{array}$ & $\begin{array}{l}\text { Décimas - Tipo } \\
\text { C }\end{array}$ & $\begin{array}{l}\text { Variante } \\
\text { matuta }\end{array}$ \\
\hline 540 & Voz Estranha & Melhores Poemas & Soneto & $\begin{array}{l}\text { Norma } \\
\text { padrão }\end{array}$ \\
\hline 541 & Zé Jacó & Aqui tem coisa & Soneto & $\begin{array}{l}\text { Norma } \\
\text { padrão }\end{array}$ \\
\hline 542 & $\begin{array}{l}\text { Zé Limeira em carne e } \\
\text { osso }\end{array}$ & Ispinho e Fulô & $\begin{array}{l}\text { Décimas - Tipo } \\
\text { A }\end{array}$ & $\begin{array}{l}\text { Norma } \\
\text { padrão }\end{array}$ \\
\hline 543 & Assaré Querido & Canção em CD & Oitavas & $\begin{array}{l}\text { Variante } \\
\text { matuta }\end{array}$ \\
\hline 544 & Defendendo a Ecologia & Canção em CD & Quartetos & $\begin{array}{l}\text { Variante } \\
\text { matuta }\end{array}$ \\
\hline 545 & $\begin{array}{l}\text { Morena e Mastruz com } \\
\text { Leite }\end{array}$ & Canção em CD & $\begin{array}{l}\text { Sextilha } \\
\text { Moderna }\end{array}$ & $\begin{array}{l}\text { Variante } \\
\text { matuta }\end{array}$ \\
\hline 546 & $\begin{array}{l}\text { Tenha Pena de Quem } \\
\text { Pena }\end{array}$ & Canção em CD & $\begin{array}{l}\text { Mistas: sext. e } \\
\text { refrão }\end{array}$ & $\begin{array}{l}\text { Variante } \\
\text { matuta }\end{array}$ \\
\hline
\end{tabular}




\section{ANEXO B - GRÁFICO DE ESTROFES}

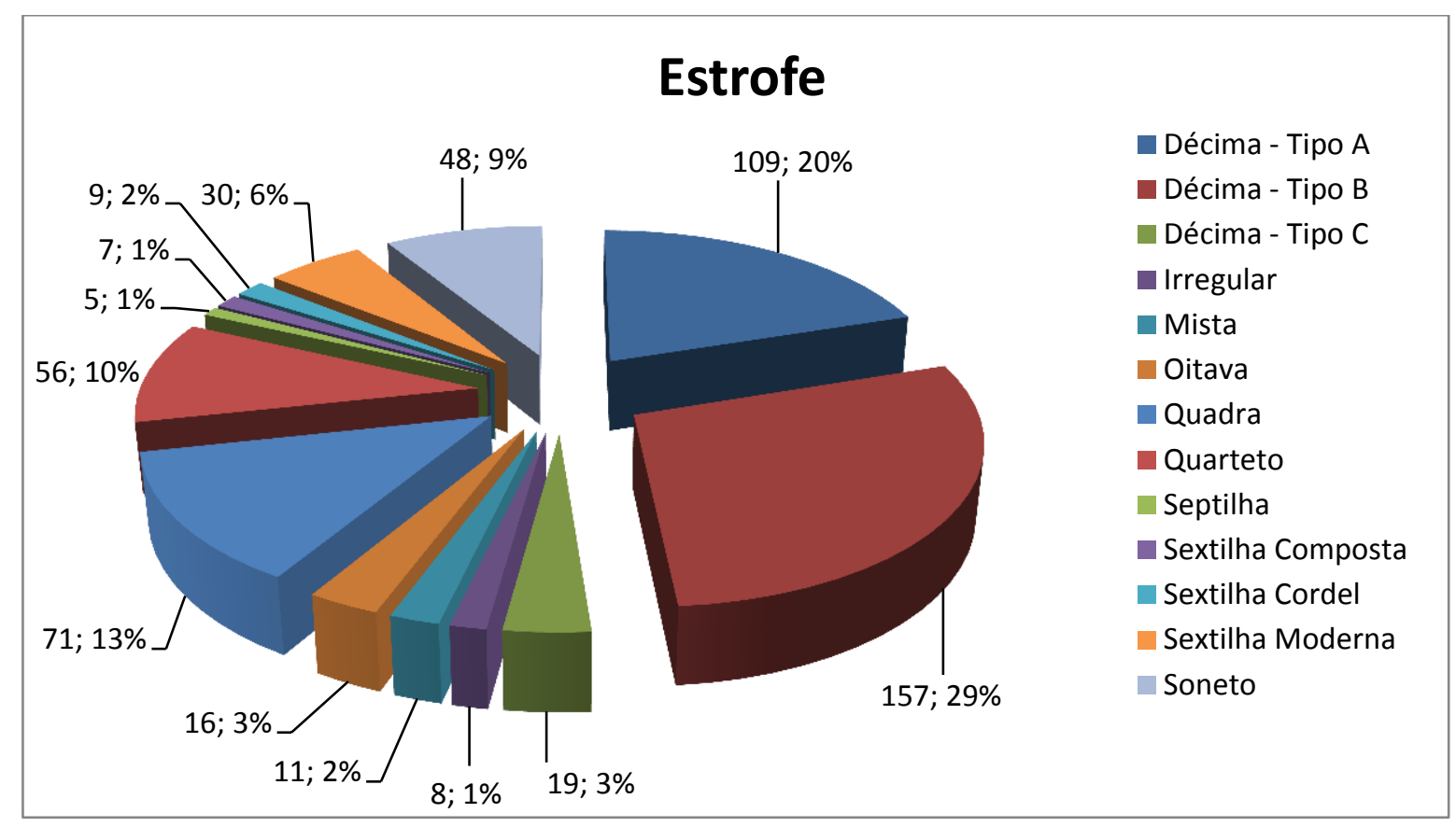

\begin{tabular}{|l|r|}
\hline Estrofe & \\
\hline $\begin{array}{l}\text { Décima - Tipo } \\
\text { A }\end{array}$ & 109 \\
\hline $\begin{array}{l}\text { Décima - Tipo } \\
\text { B }\end{array}$ & 157 \\
\hline $\begin{array}{l}\text { Décima - Tipo } \\
\text { C }\end{array}$ \\
\hline Irregular & 19 \\
\hline Mista & 8 \\
\hline Oitava & 11 \\
\hline Quadra & 16 \\
\hline Quarteto & 71 \\
\hline Septilha & 56 \\
\hline $\begin{array}{l}\text { Sextilha } \\
\text { Composta }\end{array}$ \\
\hline Sextilha Cordel & 7 \\
\hline $\begin{array}{l}\text { Sextilha } \\
\text { Moderna }\end{array}$ \\
\hline Soneto & 30 \\
\hline
\end{tabular}




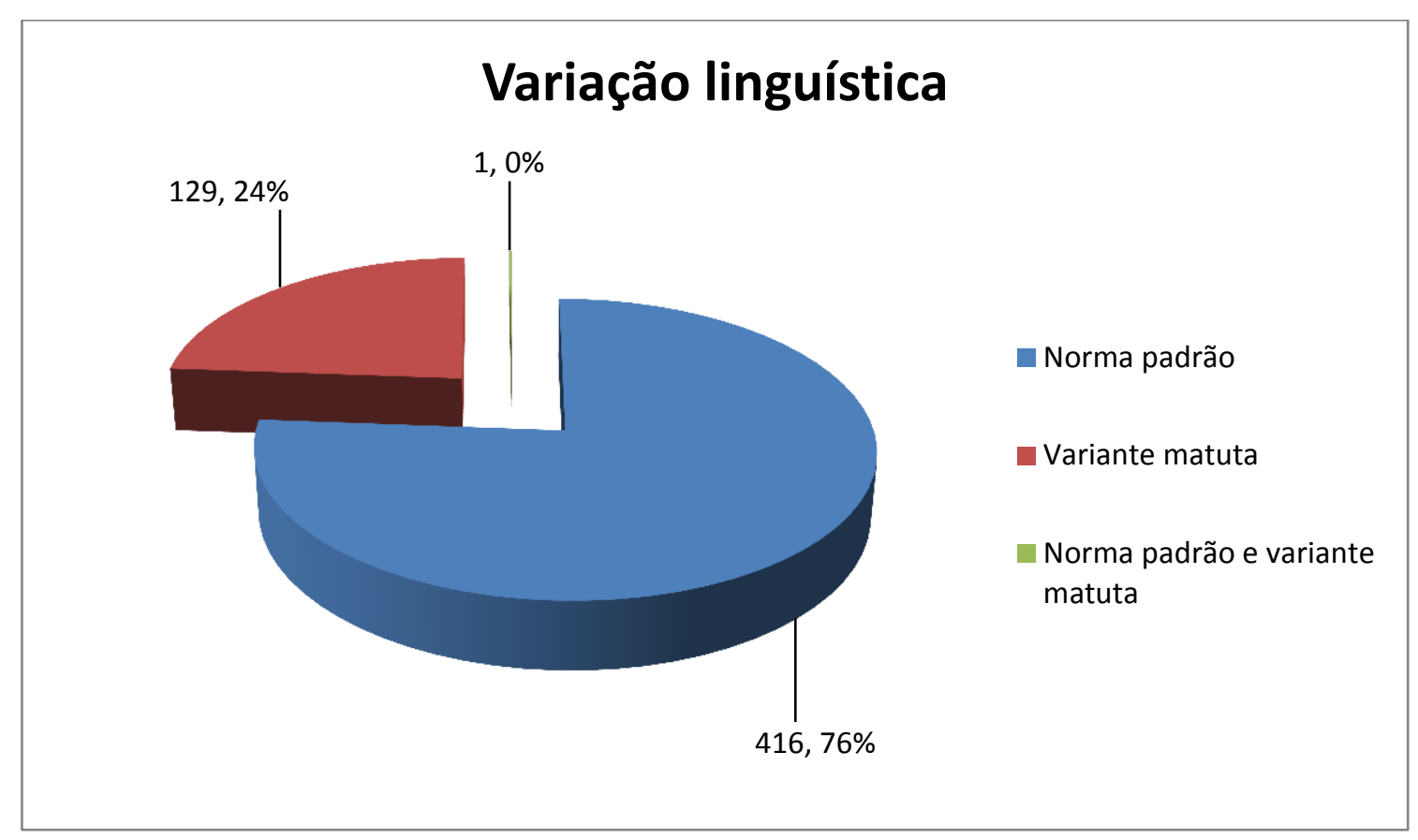

\begin{tabular}{|l|r|}
\hline \multicolumn{2}{|c|}{ Variação linguística } \\
\hline Norma padrão & 416 \\
\hline Variante matuta & 129 \\
\hline $\begin{array}{l}\text { Norma padrão e variante } \\
\text { matuta }\end{array}$ & 1 \\
\hline
\end{tabular}




\section{ANEXO D - GRÁFICO DE NORMA PADRÃO}

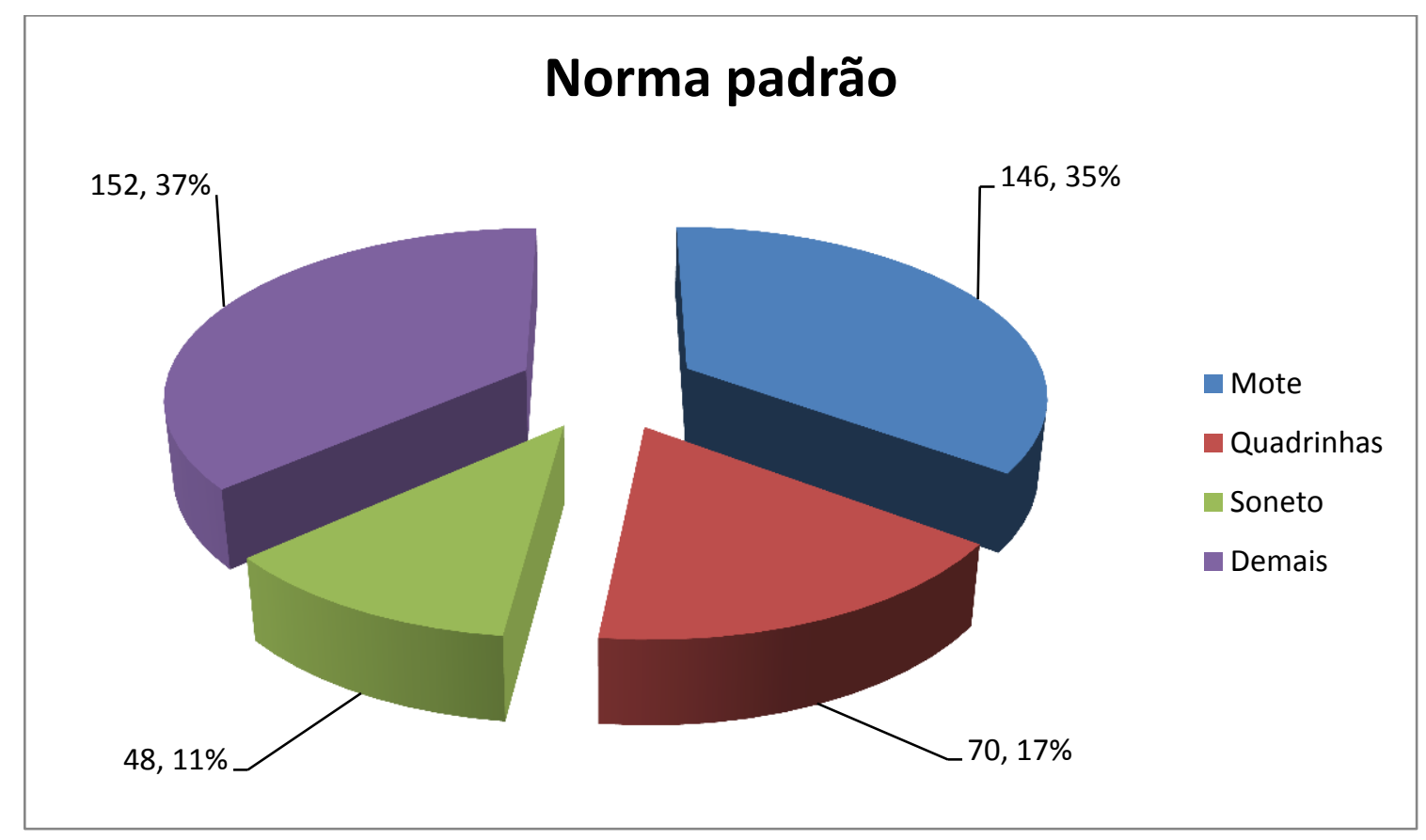

\begin{tabular}{|l|r|}
\hline \multicolumn{2}{|c|}{ Norma padrão } \\
\hline Mote & 146 \\
\hline Quadrinhas & 70 \\
\hline Soneto & 48 \\
\hline Demais & 152 \\
\hline
\end{tabular}

